UNIVERSIDADE DE SÃO PAULO

FACULDADE DE FILOSOFIA, CIÊNCIAS E LETRAS DE RIBEIRÃO PRETO DEPARTAMENTO DE PSICOLOGIA

PROGRAMA DE PÓS-GRADUAÇÃO EM PSICOLOGIA

Estilos de Aprendizagem em ações educacionais ofertadas a distância: Evidências de Validade, Validade Convergente e Análise Conceitual.

RAÍSSA BÁRBARA NUNES MORAES

RIBEIRÃO PRETO

2016 


\title{
Estilos de Aprendizagem em ações educacionais ofertadas a distância: Evidências de Validade, Validade Convergente e Análise Conceitual.
}

\author{
RAÍSSA BÁRBARA NUNES MORAES
}

Dissertação apresentada ao Programa de Pós-Graduação de Psicologia do Departamento de Psicologia da Faculdade de Filosofia, Ciências e Letras de Ribeirão Preto da Universidade de São Paulo, como parte das exigências para a obtenção do título de Mestre em Ciências. Área de concentração: Psicologia.

Orientadora: Prof. ${ }^{a}$ Dr. ${ }^{a}$ Thaís Zerbini

RIBEIRÃO PRETO

2016 
Autorizo a reprodução e divulgação total ou parcial deste trabalho, por qualquer meio convencional ou eletrônico, para fins de estudo e pesquisa, desde que citada a fonte.

Moraes, Raíssa Bárbara Nunes

Estilos de Aprendizagem em ações educacionais ofertadas à distância: evidências de validade, validade convergente e análise conceitual. Ribeirão $\quad$ Preto, $2010 . \quad 151$ p.

Dissertação de Mestrado, apresentada à Faculdade de Filosofia, Ciências e Letras de Ribeirão Preto/USP. Área de concentração: Psicologia.

Orientador: Thaís Zerbini

1. Educação a Distância. 2. Aprendizagem. 3. Estilos de Aprendizagem. 4. Estratégias de Aprendizagem. 5. Validação Convergente. 
Estilos de Aprendizagem em ações educacionais ofertadas a distância: Evidências de Validade, Validade Convergente e Análise Conceitual.

Dissertação parcialmente financiada pela CAPES/CNPq (outubro a fevereiro de 2015) e pela Fundação de Amparo à Pesquisa do Estado de São Paulo (FAPESP) (março de 2015 a maio de 2016). 
Nome: Moraes, R. B. N.

Título: Estilos de Aprendizagem em ações educacionais ofertadas a distância: Evidências de Validade, Validade Convergente e Análise Conceitual.

Dissertação apresentada à Faculdade de Filosofia, Ciências e Letras de Ribeirão Preto da Universidade de São Paulo para obtenção do título de Mestre em Psicologia

Aprovada em:

Banca Examinadora:

Prof.(a) Dr.(a)

Instituição:

Assinatura:

Prof.(a) Dr.(a)

Instituição:

Assinatura:

Prof.(a) Dr.(a)

Instituição:

Assinatura: 
"Ensinar é um exercício de imortalidade.

De alguma forma continuamos a viver naqueles cujos olhos aprenderam a vero mundo pela magia da nossa palavra. $O$ professor, assim, não morre jamais".

Rubem Alves 


\section{AGRADECIMENTOS}

A Deus e aos meus amigos espirituais, por sempre me darem força, energia e intuição para seguir os melhores caminhos e tomar as melhores decisões.

A minha mãe Wanda, pelo esforço constante para meu crescimento pessoal e profissional, por todo amor, por toda preocupação, por toda sabedoria. Sem você, eu nada seria.

Ao meu pai João, por todo carinho e dedicação, por todo apoio aos caminhos que escolhi traçar.

Ao meu irmão Renato, pelo intercâmbio de conhecimento, pelas discussões acadêmicas ou pessoais, por ser um grande suporte na minha vida.

Ao Yurín, por ter tanta compreensão, empatia e afeto comigo. Pelas conversas diárias nas quais me engradece sempre, como pessoa e profissional.

À Taiunara, pela presença constante, pela amizade simples e sem interesse, e por tantos valores que me agrega.

À Thaís Zerbini, por todo conhecimento que a mim proporcionou, por todas as orientações acadêmicas, profissionais e pessoais. Por ser uma pessoa da qual eu me orgulho em trabalhar com.

A todos os membros do Laboratório de Psicologia Organizacional e do Trabalho (LabPOT), pelas discussões, grupos de estudo e ajuda mútua que foram de essencial importância ao meu trabalho.

À universidade participante, alunos e funcionários, pela colaboração que proporcionou a produção de novos conhecimentos.

À Fundação de Amparo à Pesquisa do Estado de São Paulo (FAPESP) pelo reconhecimento da relevância desta pesquisa e apoio ao seu desenvolvimento.

Ao Paulo Vinícius, por todo amor, carinho e companheirismo. 


\section{Sumário}

Lista de Figuras.......................................................................................... $\mathrm{x}$

Lista de Tabelas................................................................................. xii

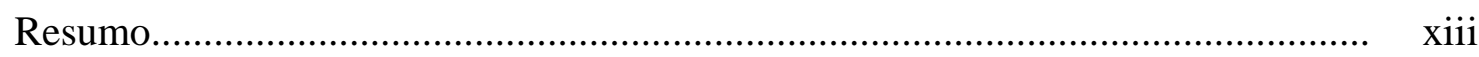

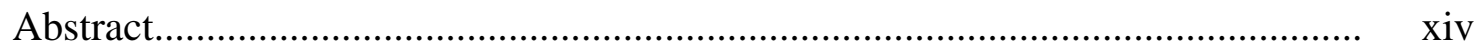

Apresentação.................................................................................................. 1

Capítulo 1. Treinamento, Desenvolvimento e Educação de Pessoas e Educação a

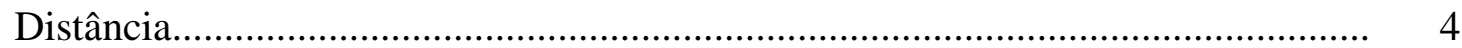

1.1.Treinamento, Desenvolvimento e Educação: definições e características......... 4

1.1.2. Modelos de avaliação de treinamento presencial e a distância....................... 6

1.2. Educação a Distância: Definições e Características........................................ 14

Capítulo 2. Variáveis relacionadas aos Estilos de Aprendizagem: Evasão e Estratégias de Aprendizagem.......................................................................... 19

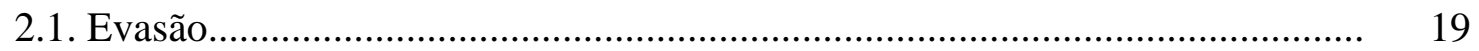

2.2. Estratégias de Aprendizagem.................................................................. $\quad 35$

Capítulo 3. Estilos de Aprendizagem................................. 46

Capítulo 4. Características Metodológicas da Pesquisa......................................... 63

4.1. Delimitação do problema, objetivos de pesquisa e modelo de investigação.... 63

4.2. Características da instituição-alvo............................................................... 64

4.3. Características do curso................................................................................... 66

4.4. População e amostra...................................................................................... $\quad 70$

4.5. Instrumentos de medida........................................................................ $\quad 72$

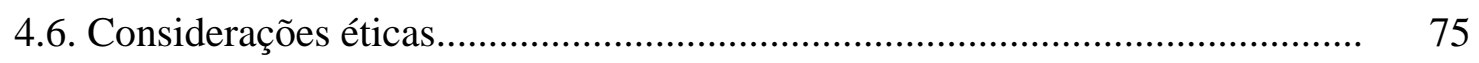

4.7. Procedimentos de coleta de dados.............................................................. 76

4.8. Procedimentos de análise de dados............................................................. 76

4.8.1. Procedimentos de análises exploratórias das estruturas empíricas dos

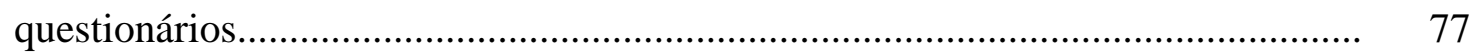

4.8.2. Procedimentos de análise dos testes ANOVAS, Testes $\mathrm{t}$ e Validade Convergente entre instrumentos

4.8.3 Procedimentos de análise de conteúdo da questão dissertativa relacionada ao motivo pelo qual evadiria do curso............................................................. 81

Capítulo 5. Resultados................................................................................ 83 


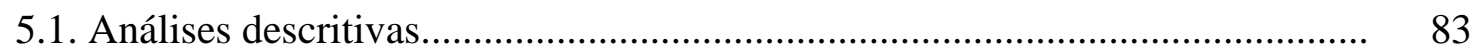

5.1.1 Estratégias de Aprendizagem............................................................... 83

5.1.2. Estilos de Aprendizagem................................................................... 86

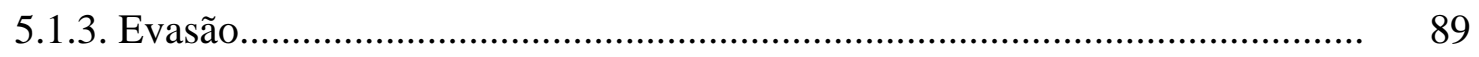

5.2. Análise de conteúdo: Motivos pelos quais o aluno abandonaria o curso.......... 89

5.3. Instrumento de Estilos de Aprendizagem: Validação Semântica e por Juízes.. 92

5.4. Análises exploratórias fatoriais das estruturas empíricas dos questionários evidências de validade.......................................................................................... 94

5.4.1. Estilos de Aprendizagem............................................................................. 95

5.4.2. Estratégias de Aprendizagem................................................................ 99

5.5. Análises Complementares sobre as Escalas: ANOVAS e Testes t.................. 105

5.6. Validade Convergente dos instrumentos de Estratégias de Aprendizagem e Estilos de Aprendizagem.................................................................................. 110

5.7. Estilos de Aprendizagem: Análise Conceitual.............................................. 111

Capítulo 6. Discussão......................................................................................... $\quad 120$

6.1. Discussões dos resultados das análises fatoriais exploratórias........................ 120

6.2. Discussões dos resultados da validação convergente dos instrumentos de Estratégias de Aprendizagem e Estilos de Aprendizagem e análise conceitual de Estilos de Aprendizagem................................................................................ 126

Capítulo 7. Conclusões................................................................................ 130

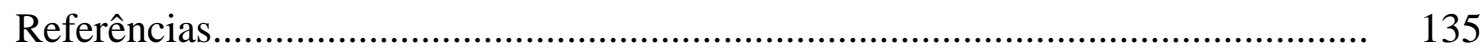




\section{Lista de figuras}

Figura 1. Estrutura geral de desenvolvimento do texto

Figura 2. Modelo de Avaliação Integrado e Somativo - MAIS (Borges-Andrade, 2006)

Figura 3. Modelo de Avaliação do Impacto do Treinamento no Trabalho -

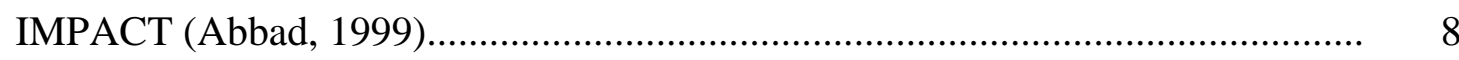

Figura 4. Modelo geral de avaliação da Transferência de Treinamento via web no Trabalho (Zerbini, 2007).

Figura 5. Modelo de investigação proposto por Martins (2012).....

Figura 6. Modelo de investigação proposto por Umekawa (2014)

Figura 7. Modelo Teórico Multinível de Predição de Impacto de Treinamento a

Distância no Trabalho e de Persistência/Evasão em Cursos Ofertados Nessa Modalidade" (Brant, 2014)....

Figura 8: Distribuição dos valores próprios (scree plot) da escala de Estilos de Aprendizagem.

Figura 9: Distribuição dos valores próprios (scree plot) da escala de Estratégias de Aprendizagem. 


\section{Lista de tabelas}

Tabela 1: Perfil da clientela de EAD (Abbad, 2007).

Tabela 2: Resultados de pesquisas nacionais e internacionais sobre "Evasão e Persistência em EAD” (Umekawa, 2014)

Tabela 3: Classificação e definições das Estratégias de Aprendizagem (Warr \& Allan, 1998; Zerbini, 2007; Martins, 2012)

Tabela 4: Pesquisas sobre Estratégias de Aprendizagem (Martins, 2012).

Tabela 5. Controle de busca da revisão bibliográfica de Estilos de Aprendizagem

Tabela 6: Revisão de literatura para Estilos de Aprendizagem.

Tabela 7: Instrumentos de Estilos de Aprendizagem (Brant, 2014)

Tabela 8. Características do curso a ser avaliado.

Tabela 9. Curso "Licenciatura em Ciências": estrutura e organização Umekawa (2014).

Tabela 10. Características da amostra

Tabela 11. Resumo das informações sobre os instrumentos a serem utilizados na pesquisa.

Tabela 12. Resultados descritivos de Estratégias de Aprendizagem.

Tabela 13. Resultados descritivos de Estilos de Aprendizagem

Tabela 14. Resultados descritivos sobre a possibilidade de Evasão.

Tabela 15. Distribuição dos motivos pelos quais os alunos evadiriam o curso

Tabela 16. Validação semântica e por juízes dos itens do instrumento de Estilos de Aprendizagem

Tabela 17. Valores próprios empíricos e aleatórios dos primeiros dez componentes de Estratégias de Aprendizagem.

Tabela 18. Estrutura empírica da Escala de Estilos de Aprendizagem.

Tabela 19. Valores próprios empíricos e aleatórios dos primeiros dez componentes de Estratégias de Aprendizagem

Tabela 20. Estrutura empírica da Escala de Estratégias de Aprendizagem

Tabela 21. Resumo das informações sobre os instrumentos utilizados nesta pesquisa.

Tabela 22. Teste de diferença entre médias (Teste $t$ ), segundo a resposta se 
abandonaria o curso.

Tabela 23. Teste de diferença entre médias (Teste $t$ ), segundo o sexo dos participantes

Tabela 24. Teste de diferença entre médias (Teste $t$ ), segundo a composição familiar dos alunos

Tabela 25. Teste de diferença entre médias (ANOVA), segundo a renda mensal dos participantes

Tabela 26: Resumo dos resultados das análises de diferenças de médias (Teste te ANOVA).

Tabela 27. Correlação entre os fatores dos instrumentos de Estilos de Aprendizagem e Estratégias de Aprendizagem.

Tabela 28. Definição de Estilos e Estratégias de Aprendizagem.

Tabela 29: Análise dos itens do instrumento de Estilos de Aprendizagem. 


\section{Resumo}

Moraes, R. B. N. (2016). Estilos de Aprendizagem em ações educacionais ofertadas a distância: Evidências de Validade, Validade Convergente e Análise Conceitual. Dissertação de Mestrado, Departamento de Psicologia, Universidade de São Paulo, Ribeirão Preto.

A necessidade constante de desenvolvimento de competências individuais e organizacionais atrelada a projetos de educação a distância (EAD) expande a possibilidade de acesso a programas de treinamento, formação e qualificação profissionais ofertados por instituições de ensino superior (IES) e outras organizações do sistema produtivo. Nota-se um grande progresso tecnológico cada vez mais disseminado no recente campo da EAD. Porém, essa modalidade de ensino é muito carente de estudos sistemáticos. Variáveis relacionadas ao perfil da clientela necessitam ser mais investigadas, como é o caso dos Estilos de Aprendizagem, que necessita de uma definição mais apurada, especialmente para garantir a qualidade dos instrumentos que se propõem a medir esse construto. Muitas vezes o seu conceito está relacionado com o conceito de Estratégias de Aprendizagem, sem grandes diferenciações entre eles. Além disso, a literatura indica que tais variáveis de características da clientela podem estar relacionadas com a Evasão em cursos na modalidade EAD. Nesse sentido, a presente pesquisa objetivou construir e verificar evidências de validade de um instrumento de medida de Estilos de Aprendizagem, bem como realizar a validade convergente com o instrumento de Estratégias de Aprendizagem, além de propor uma discussão conceitual acerca dos Estilos de Aprendizagem. Ao final desse estudo, o instrumento de Estilos de Aprendizagem foi construído, passou por validação semântica, por juízes e foram verificadas evidências de validade estatística. Foi demonstrado também que os alunos que fizeram mais uso das Estratégias de Aprendizagem Autorregulatórias, bem como das Estratégias Comportamentais e valorizam mais os aspectos do ambiente no quais realiza os seus estudos (ou seja, possuem mais Preferências Ambientais) tendem a não abandonar o curso. A validação convergente entre os instrumentos de Estilos de Aprendizagem e Estratégias de Aprendizagem demonstraram que os instrumentos refletem o histórico de relacionamento entre esses conceitos. Muitos fatores de Estratégias de Aprendizagem se relacionam com o instrumento de Estilos de Aprendizagem. Os resultados também possibilitaram uma definição operacional de Estilos de Aprendizagem no campo da Psicologia Organizacional e do Trabalho (POT). Para pesquisas futuras, recomenda-se o uso de técnicas estatísticas mais robustas, como o uso de Análise Fatorial Confirmatória, bem como a Modelagem de Equações Estruturais, que poderiam mensurar com maior exatidão o quanto os Estilos e as Estratégias de Aprendizagem influenciam a Evasão em Ações Educacionais Ofertadas a Distância em contexto de IES.

Palavras-chave: Educação a Distância; Aprendizagem; Estilos de Aprendizagem; Estratégias de Aprendizagem; Validação convergente. 


\begin{abstract}
Moraes, R. B. N. (2016). Learning styles in e-learning actions: Validity evidences, convergent validity and conceptual analysis. Dissertação de Mestrado, Departamento de Psicologia, Universidade de São Paulo, Ribeirão Preto.

The constant need to develop individual and organizational competences linked to e-learning projects expands the possibility of access to professional training and qualification programs offered by higher education institutions (HEIs) and other organizations of the productive system. A great technological progress is becoming increasingly widespread in this recent elearning field. However, this type of education is very lacking in systematic studies. Variables related to the customer profile needs to be further investigated, like the Learning Styles variable. This last requires a more precise definition, especially to ensure the quality of the instruments used to measure this construct. The Learning Styles concept is often related to the Strategy Styles concept without mentioning the proper differences between them. Besides that, the literature indicates that such costumer's characteristics variables may be related to the Evasion in e-learning courses. This research aimed to carry out the conceptual analysis of Learning Styles through the construction and verification of validity evidence of a measuring instrument and the convergent validity with Learning Strategies. The Learning Styles instrument was built, underwent semantic validation by judges and evidence of statistical validity were verified. It was also shown that students who made more use of Self-Regulatory Learning Strategies, as well as Behavioral Strategies and value the aspects of the environment in which they realize its studies (ie, have more Environmental Preferences) tend not to leave the course. The convergent validity between Learning Styles and Learning Strategies instruments showed that the instruments reflect the historical relationship between these concepts. Many aspects of Learning Strategies are also related to the Learning Styles aspects. The results showed an adequate definition of Learning Styles in the field of Organizational and Work Psychology (OWP). For future research, it is recommending the use of more consistent statistical techniques such the Confirmatory Factor Analysis as well as Structural Equation Modeling, which could measure more accurately how the Styles and Learning Strategies influence the Evasion in e-learning in the higher education institutions context.
\end{abstract}

Keywords: E-learning; Learning; Learning Styles; Learning Strategies; Convergent Validity. 


\section{Apresentação}

As transformações pedagógicas, políticas e tecnológicas que perpassam os vigentes contextos de estudo e trabalho não só resultam em significativas modificações nas práticas e ferramentas utilizadas, bem como exigem dos agentes envolvidos - profissionais e estudantes - notável capacidade de atualização e adaptação (Abbad, Zerbini \& Souza, 2010). Nesse contexto, os programas de Treinamento, Desenvolvimento e Educação (TD\&E) despertam o interesse científico pelo modo como vêm sendo oferecidos, uma vez que se constituem instrumentais de expressivo valor para ações de formação educacional favorecedoras da aquisição de competências vitais e valorizadas pela sociedade atual (Coelho Jr. \& BorgesAndrade, 2008).

Frente a cenários altamente voláteis, os eventos instrucionais a distância tornam-se uma estratégia para instituições de ensino superior (IES) e organizações laborais, já que propiciam o estabelecimento dos mecanismos responsáveis pela aprendizagem efetiva e otimização de desempenhos. Experimentando um crescimento vertiginoso, a Educação a Distância (EAD) atesta suas inegáveis contribuições aos processos formativos ao se estabelecer como iniciativa educacional que permite servir a um quinhão de indivíduos cada vez maior, diminuir custos e otimizar o tempo (Coll, Mauri \& Onrubia, 2010; Varanda, Zerbini \& Abbad, 2010; Zerbini \& Abbad, 2008).

A EAD enfrenta sérios desafios envolvendo fatores que interferem sobre a eficiência e empregabilidade de tais esforços instrucionais. Uma das mais relevantes problemáticas existentes no campo da Educação e do Treinamento a Distância é a escassa produção e sistematização de conhecimentos acerca das causas que interferem sobre o avanço e conclusão das ações formais de ensino-aprendizagem não presenciais (Abbad, Carvalho \& Zerbini, 2006; Sales, 2009; Walter, 2006).

Uma das características da EAD é a de ser adaptável uma vez que é planejada, normalmente, para ser usada por uma grande variedade de indivíduos com diferentes habilidades, preferências ou Estilos de Aprendizagem (Brusilovsky \& Peylo, 2003). As investigações sobre os Estilos de Aprendizagem fornecem informações para o aperfeiçoamento dos métodos instrucionais e para mudanças de comportamento dos que aprendem (Bjork, Dunlosky \& Kornell, 2013; Vermunt, 2005).

Diante de revisões da literatura, nota-se que o conceito de Estilos de Aprendizagem tem sido pouco estudado na área de Psicologia Organizacional e do Trabalho (POT). Ainda não se tem clareza sobre sua definição operacional, pois as existentes muitas vezes são divergentes 
entre si, ou correlacionadas com outras definições, como por exemplo, Estratégias de Aprendizagem. Brant (2014) alerta sobre a falta de instrumentos de medida de Estilos de Aprendizagem com bons índices de validade, e especialmente, aponta que não encontrou estudos relacionando Estilos de Aprendizagem e as características individuais no campo específico da EAD, que é o campo de estudo desta de pesquisa.

Diante desse cenário, a presente pesquisa objetivou construir e verificar evidências de validade de um instrumento de medida de Estilos de Aprendizagem, bem como realizar a validade convergente com o instrumento de Estratégias de Aprendizagem, além de propor uma discussão conceitual acerca dos Estilos de Aprendizagem. Além disso, objetivou estabelecer relações entre Estilos de Aprendizagem e características individuais do aluno (sexo, profissão, idade, composição familiar e opinião sobre uma possível evasão do curso).

Para auxiliar o acompanhamento do texto, a Figura 1 mostra a forma como os capítulos e as seções estão organizados e sua sequência de exposição no presente estudo.

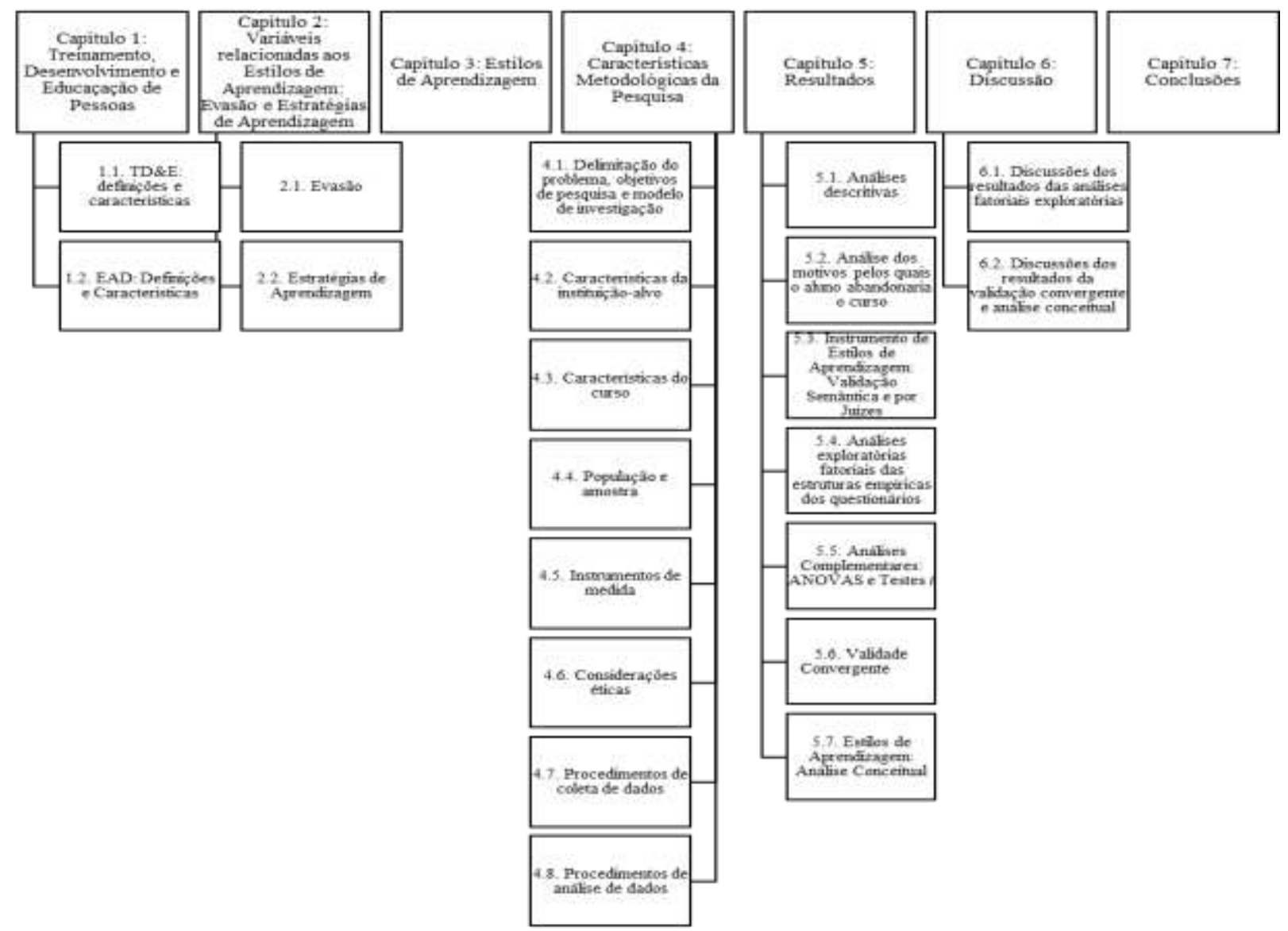

Figura 1. Estrutura geral de desenvolvimento do texto. 
O Capítulo 1 trata do campo de estudo no qual essa pesquisa ocorre: discorre sobre os componentes e as propriedades específicas do sistema de Treinamento, Desenvolvimento e Educação (TD\&E), bem como apresenta um retrospecto acerca dos progressos, tendências e obstáculos concernentes ao subsistema de Avaliação de efeitos de TD\&E. São descritos alguns modelos de avaliação destinados a treinamentos presenciais e a distância, disponíveis na literatura internacional e brasileira. A modalidade EAD é caracterizada enquanto recurso utilizado, nacional e internacionalmente, para a promoção do ensino em contextos de Organização e Trabalho (O\&T) e por IES.

No Capítulo 2 é detalhado o trajeto da revisão de literatura sobre as variáveis relacionadas à principal variável de interesse deste estudo: a Evasão e as Estratégias de Aprendizagem. São apresentados e discutidos terminologias, conceitos, características e resultados de pesquisa relacionados as essas variáveis.

O capítulo 3, por sua vez, apresenta a revisão e análise de literatura da principal variável de interesse deste estudo: os Estilos de Aprendizagem. O percurso da revisão é apresentado, bem como os principais resultados encontrados, que serviram de embasamento teórico para os resultados da pesquisa.

A delimitação do problema, a justificativa e os objetivos da pesquisa se encontram dispostos no Capítulo 4. Ademais, expõem-se as características da IES parceira. São delimitados os instrumentos de medida, os cuidados éticos, assim como os procedimentos de coleta e análise de dados.

O Capítulo 5 apresenta detalhamente todos os resultados dessa pesquisa: os resultados descritivos dos instrumentos de Estratégias de Aprendizagem e Estilos de Aprendizagem, a validação semântica e por juízes do instrumento de Estilos de Aprendizagem e os resultados das análises fatoriais exploratórias, que foram complementados os Testes $t$ e ANOVA. Por fim, é apresentada a validação convergente entre os instrumentos utilizados na pesquisa e a análise conceitual do construto de Estilos de Aprendizagem.

As discussões entre os principais resultados da presente pesquisa com os objetivos propostos e com resultados obtidos em pesquisas descritas na revisão da literatura são apresentadas no capítulo 6.

Finalmente, no capítulo 7 apresentadas as conclusões deste estudo, além de apresentar suas principais contribuições e limitações, e propor uma agenda de pesquisa. 


\section{CAPÍTULO 1. TREINAMENTO, DESENVOLVIMENTO E EDUCAÇÃO DE PESSOAS E EDUCAÇÃO A DISTÂNCIA}

\section{Objetivo do capítulo 1}

O presente capítulo apresenta o contexto do estudo. Descreve os conceitos da área de TD\&E, bem como alguns modelos de avaliação. Em seguida, discorre sobre algumas definições e características da modalidade EAD como um expediente de ensino e sua inclusão em contextos de organizações e trabalho (O\&T) e Instituições de Ensino Superior (IES).

\subsection{Treinamento, Desenvolvimento e Educação: definições e características}

Ações desenvolvidas no campo de TD\&E cada vez mais se destacam em termos de importância e necessidade, dado que os novos contextos de ensino e trabalho reclamam com premência por iniciativas aptas a sanar lacunas de competências e que promovam sua constante atualização visando o bom desempenho acadêmico e profissional.

A área de TD\&E compreende o estudo de ações educacionais que possuem o intuito de propiciar oportunidades de aprendizagem aos integrantes de uma organização, visando obter melhorias em seus desempenhos (Borges-Andrade, 2006). Tais ações se caracterizam como estratégias da empresa para a manutenção da competitividade no mercado através do investimento na qualificação de pessoal e no desenvolvimento de competências compatíveis aos objetivos e metas organizacionais (Abbad, Zerbini \& Souza, 2010). É por meio dos eventos de TD\&E que são promovidas inovações constantes, em consonância com as exigências impostas pelo cenário globalizado, evitando, assim, a obsolescência das organizações (Coelho Jr. \& Borges-Andrade, 2008).

De acordo com Salas, Tannenbaum, Kraiger e Smith-Jentsch (2012), as atividades de treinamento e desenvolvimento são fundamentais para a construção e a manutenção de uma força de trabalho efetiva, bem como permitem que as organizações se adaptem, compitam, inovem, produzam, mantenham-se seguras, melhorem o atendimento e atinjam metas. Além dos objetivos de aprender e transferir novos conhecimentos, habilidades e atitudes (CHAs) para o ambiente de trabalho, proporcionados pelos eventos instrucionais, as organizações almejam que essas novas competências adquiridas possam provocar impactos nos processos de trabalho das equipes e resultados organizacionais (Aguinis \& Kraiger, 2009; Zerbini, Coelho, Abbad, Mourão, Alvim \& Loiola, 2012); transpondo assim o nível individual, mas agregando valor também nos níveis meso e macro (Burke \& Hutchins, 2007). 
De forma geral, é possível afirmar a existência de certa falta de concordância quanto aos termos que designam o campo de TD\&E; havendo uma nítida pluralidade de definições e elementos na área, diversos problemas conceituais são observados (Vargas \& Abbad, 2006). Vargas e Abbad (2006) chamam a atenção para tal multiplicidade de compreensões e alertam para a necessidade de uma avaliação mais aprofundada de tais elementos, já que com o passar do tempo, e consequente desenvolvimento da área de treinamento, houve a incorporação de novos termos ainda pouco definidos e compreendidos. Apesar das diferenças conceituais observadas no campo das ações de TD\&E, Zerbini (2007) considera que quando tais estratégias são empregadas corretamente e em conjunto, o processo de aprendizagem é favorecido e estimulado. Cabe avaliar quais iniciativas, dentro de suas características e limitações, melhor se adequam aos objetivos educacionais estabelecidos.

De acordo com Borges-Andrade (2006), pode-se considerar que as ações de TD\&E são estruturadas a partir de três subsistemas basais: Avaliação de necessidades de ações instrucionais; Planejamento e Execução; e Avaliação de treinamento. O processo de avaliação de necessidades (ANT) é responsável por determinar onde a ação instrucional é necessária, qual conteúdo deve ser treinado e quem são os agentes a participarem da mesma. Seu princípio se dá a partir da verificação ou adiantamento de uma específica necessidade de desempenho. Para tanto, é necessária uma análise acurada da problemática identificada, isto porque, frequentemente, tais queixas decorrem de condições inadequadas de trabalho ou de reduzidos níveis de motivação para o exercício profissional - condições estas que não se constituem como alvo das ações educacionais de TD\&E (Gondin \& Silva, 2004). Havendo a constatação de que o problema de desempenho é passível de resolução por meio de remoção de deficiências de CHAs, inicia-se efetivamente o processo de avaliação de necessidades, realizado a partir das seguintes análises: organizacional, de tarefas e individual.

Após identificadas as lacunas de competências a serem treinadas, o subsistema seguinte, Planejamento Instrucional, tem sua gênese na definição dos desempenhos e competências a serem desenvolvidos pelos participantes. De posse de tais elementos e peças de informação, o processo de planejamento de ações de TD\&E é iniciado pela definição dos objetivos educacionais, ou seja, pela determinação dos desempenhos esperados da parte dos treinandos ao final do evento. O seguinte passo do planejamento de TD\&E corresponde a escolha da modalidade de entrega: para que o planejador se decida por ações presenciais, a distância ou semipresenciais é preciso que o mesmo analise o perfil demográfico, funcional e profissional dos agentes envolvidos no evento. Os desempenhos almejados pelos objetivos educacionais 
estabelecidos também devem ser levados em conta, pois possibilitam compreender sua complexidade e a necessidade de maior contato, por parte do aprendiz, com determinadas situações. A eficácia de cada modalidade de ensino, a disponibilidade, quanti e qualitativa, dos recursos financeiros, materiais, tecnológicos e humanos também devem ser considerados durante a escolha a ser feita (Abbad, Zerbini, Carvalho \& Meneses, 2006).

Por último, as avaliações dos efeitos decorrentes de ações de TD\&E se constituem como valioso e necessário instrumental para a efetividade e êxito do programa educacional empreendido, especialmente em situações nas quais houve uma elaboração pouco sistemática e criteriosa dos subsistemas de avaliação de necessidades de treinamento e planejamento. Pode-se afirmar que tal subsistema objetiva exercer controle sobre o processo, proporcionar feedback aos demais componentes, tomar decisões acerca do treinamento e, por fim, torná-lo capaz de promover alterações no ambiente em questão. Inúmeros modelos utilizados para tal fim encontram-se disponíveis na literatura, sendo o modelo proposto por Kirkpatrick (1976) um modelo clássico, marco pioneiro na área.

No que tange à avaliação das ações educacionais, foco desta pesquisa, os estudos realizados no âmbito deste subsistema concentram seus esforços no refinamento das metodologias e procedimentos hábeis a analisar ações educativas de modo a garantir a transferência e aplicação das competências adquiridas (Salas \& Cannon-Bowers, 2001).

Considerando os resultados advindos de revisões clássicas empreendidas no campo da Psicologia (Aguinis \& Kraiger, 2009; Raymond, Alena, Clarke \& Klein, 2014; Salas \& Cannon-Bowers, 2001; Tannenbaum \& Yukl, 1992), é possível constatar progressos que perpassam o subsistema de avaliação de ações educacionais. Verifica-se a necessidade de transpor limitações que restringem a eficiência do sistema de TD\&E e comprometem o estado técnico-científico da área, tal como: restrições culturais e técnicas no uso de avaliações de aprendizagem; dificuldades de proceder a avaliações em níveis mais abrangentes; inadequações ou falta de manejo de resultados gerados por ações de TD\&E; carência de orientações teórico-metodológicas que embasem avaliações em termos de resultados organizacionais. Ademais, estudos voltados à avaliação da efetividade de ações instrucionais ainda são escassos e apresentam incongruências quanto aos objetivos pretendidos (Iglesias \& Salgado, 2012).

\subsubsection{Modelos de avaliação de treinamento presencial e à distância}

No que tange a proposição de modelos avaliativos multivariados e sistemáticos de eventos 
instrucionais que objetivam relacionar variáveis explicativas de diferentes fenômenos, incluindo a Evasão, diversos progressos vêm sendo registrados desde os anos 60 até a atualidade (Sales, 2009). Dessa forma, inúmeros instrumentos utilizados para tal fim encontram-se disponíveis na literatura, sendo o modelo elaborado por Kirkpatrick (1976) um marco pioneiro na área. Havendo o enfraquecimento dos chamados modelos clássicos de avaliação, que consideravam apenas os resultados produzidos pelas ações educativas, aqueles de feitio mais contemporâneo vêm ganhando notoriedade por também focalizarem componentes capazes de explicar a ocorrência dos resultados de eventos instrucionais (Zerbini, Abbad \& Mourão, 2012). Dentre tais modelos denominados integrativos, sobressaise aquele desenvolvido por Borges-Andrade $(1982,2006)$ e atualizado em suas implicações teóricas e práticas por Borges-Andrade, Zerbini, Abbad e Mourão (2013), intitulado Modelo de Avaliação Integrada e Somativa (MAIS).

O modelo MAIS é composto por cinco componentes: (1) insumo, (2) procedimentos, (3) processo, (4) resultados e (5) ambiente, sendo que este último é desdobrado em avaliação de necessidades, suporte, disseminação e efeitos em longo prazo.

O componente Insumo refere-se a fatores anteriores à instrução - fatores físicos e sociais, e estados comportamentais e cognitivos - que podem influenciar os seus resultados (ex.: variáveis motivacionais, sociodemográficas, psicossociais, cognitivo-comportamentais). Procedimentos são operações necessárias para facilitar o processo de aprendizagem ou produzir resultados instrucionais como a clareza, precisão e sequência de objetivos, meios e estratégias instrucionais, exercícios propostos. Processo refere-se a resultados intermediários ou efeitos parciais do treinamento ocorridos no comportamento dos aprendizes à medida que os procedimentos são implantados (ex.: resultados em exercícios práticos, relações interpessoais estabelecidas entre pares e tutores). Resultados são os efeitos produzidos pelo treinamento, ou seja, são os desempenhos finais imediatos decorrentes de TD\&E.

O Ambiente representa o contexto em que se insere a ação de TD\&E, e é dividido em quatro subcomponentes, a saber: (1) necessidades são as lacunas importantes entre desempenhos esperados e realizados - identifica os CHAs não dominados pelos indivíduos, mas necessários para apresentarem desempenhos esperados no trabalho; (2) suporte refere-se aos fatores ambientais que podem facilitar ou dificultar ações de treinamento, como: custos, recursos da organização, variáveis do lar, da comunidade ou da organização; (3) disseminação são as informações disponíveis na organização sobre o treinamento, como o programa, o material e a divulgação (natureza, método e canais); e (4) efeitos em longo prazo referem-se 
às consequências ambientais das ações educacionais, como: comportamento no cargo ou impacto do treinamento no trabalho, mudança organizacional e valor final.

Logo, o MAIS considera variáveis do curso, do ambiente e da pessoa, anteriores e posteriores à instrução. A Figura 2 apresenta o esquema gráfico do modelo.

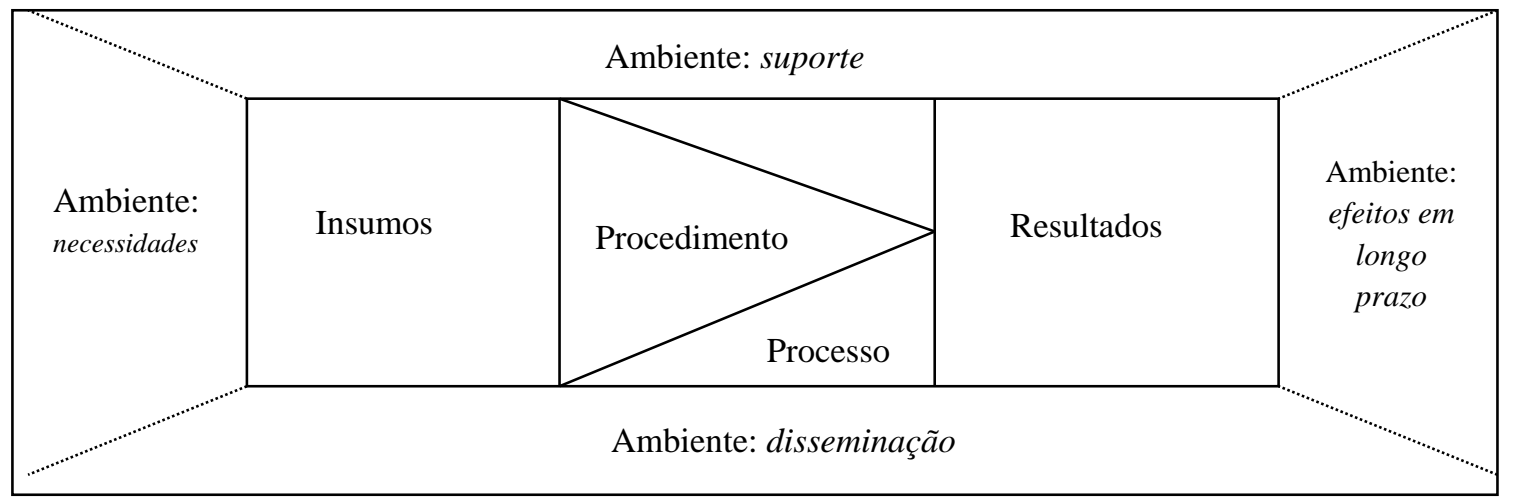

Figura 2. Modelo de Avaliação Integrado e Somativo - MAIS (Borges-Andrade, 1982, 2006).

Inspirada no modelo MAIS, Abbad (1999) propôs o Modelo de Avaliação do Impacto do Treinamento no Trabalho - IMPACT. Este é composto por sete itens: percepção de suporte organizacional; características de treinamento; características da clientela; reação; aprendizagem; suporte à transferência; e impacto do treinamento no trabalho. O modelo é representado pela Figura 3.

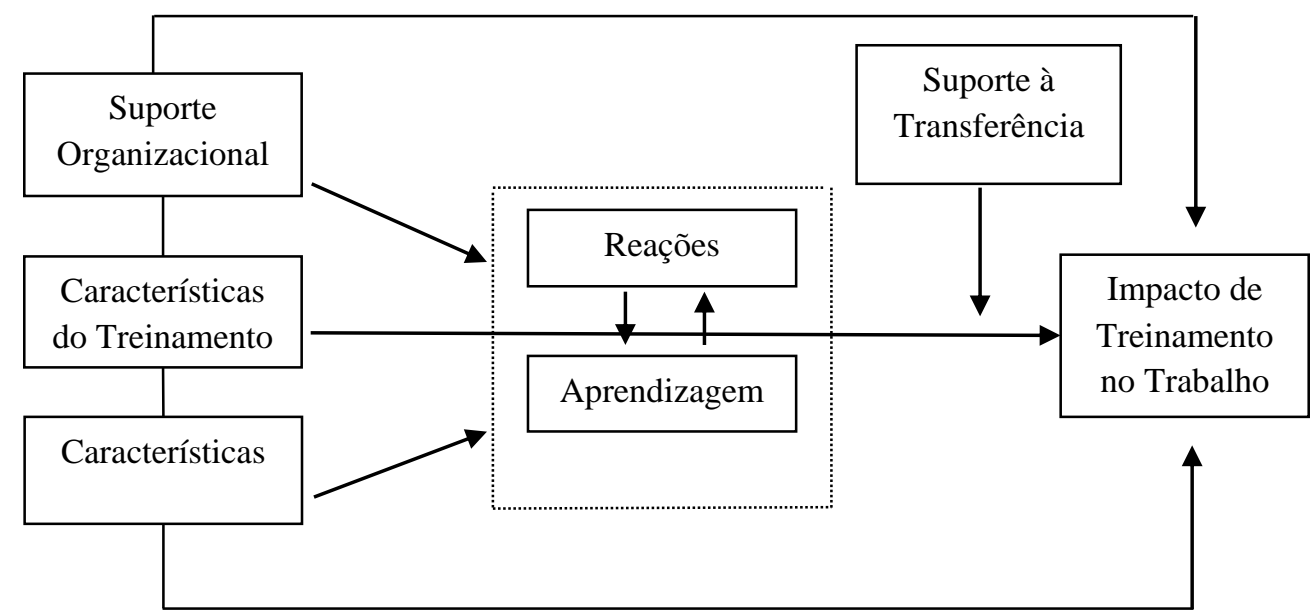

Figura 3. Modelo de Avaliação do Impacto do Treinamento no Trabalho - IMPACT (Abbad, 1999)

O IMPACT pretende investigar o relacionamento entre variáveis relativas ao indivíduo, ao treinamento, ao contexto organizacional e aos resultados imediatos do treinamento, tendo como variável critério o impacto do treinamento no trabalho. 
A definição das variáveis preditoras e dos níveis de avaliação presentes no modelo é explicitada a seguir: (1) Suporte Organizacional compreende a opinião dos participantes acerca das condições do ambiente e o nível de apoio oferecido para efetivamente participarem do treinamento. (2) Características de Treinamento dizem respeito a variáveis relacionadas ao próprio curso (área de conhecimento, duração, qualidade do material didático, etc.). (3) Características da Clientela representam o conjunto de informações demográficas, funcionais, motivacionais e atitudinais dos participantes. (4) Reação é uma medida de satisfação dos participantes com relação a diversos aspectos das ações educacionais (aplicabilidade e utilidade, programação de atividades, desempenho do instrutor, entre outros). (5) Aprendizagem refere-se ao grau de assimilação e retenção dos conteúdos ensinados no curso, medida em termos dos escores obtidos pelo participante em testes ou provas de conhecimentos parciais e finais. (6) Suporte à Transferência compreende o suporte psicossocial e material à transferência de novas habilidades aprendidas em treinamento. (7) Impacto do Treinamento no Trabalho: impacto em profundidade diz respeito aos efeitos diretos e específicos extraídos dos objetivos instrucionais previamente definidos competências a serem desenvolvidas no treinamento; e impacto em amplitude pretende medir os efeitos da ação instrucional no desempenho global, atitudes e motivação do indivíduo.

Zerbini (2007), com base nos Modelos MAIS e IMPACT, desenvolveu um modelo específico para a avaliação de treinamentos a distância, ofertados pela internet, focalizando a identificação das variáveis preditivas da transferência de treinamento em cursos de qualificação profissional. Analisando um curso gratuito do SEBRAE (Serviço Brasileiro de Apoio às Micro e Pequenas Empresas) - "Iniciando um Pequeno Grande Negócio" oferecido integralmente pela internet, a autora elaborou o modelo que aferiu o poder preditivo de variáveis individuais (Estratégias de Aprendizagem), de contexto de estudo (ambiente e procedimentos) e de reações (reação aos procedimentos e ao tutor), quanto à transferência de treinamento para o ambiente de trabalho. A Figura 4 apresenta o modelo. 


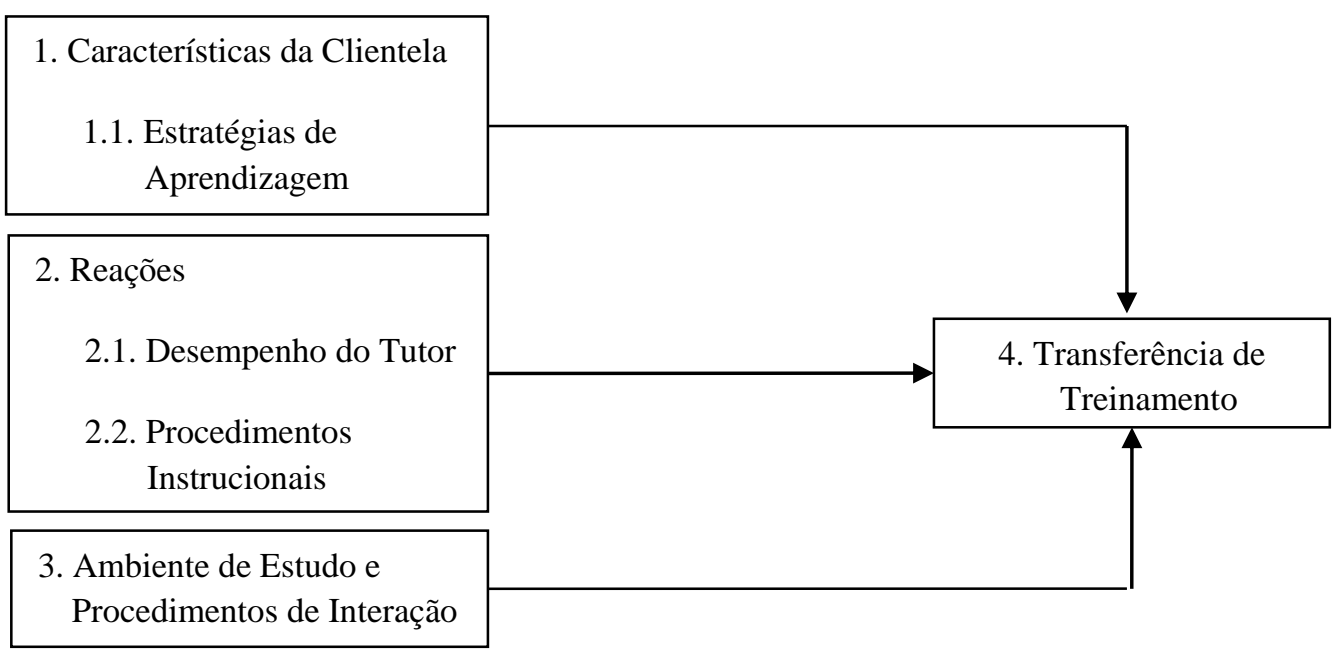

Figura 4. Modelo geral de avaliação da Transferência de Treinamento via web no Trabalho (Zerbini, 2007).

As variáveis envolvidas no modelo supracitado são definidas como: (1) Ambiente de estudo e Procedimentos: aspectos do contexto pessoal de estudo do aluno e do próprio curso que podem dificultar a permanência do estudante no evento instrucional; (2) Estratégias de Aprendizagem: capacidades cognitivas complexas aprendidas pelo indivíduo ao longo da vida. Envolve capacidades cognitivas, habilidades comportamentais e de autocontrole emocional, empregadas pelo aprendiz para administrar os próprios processos psicológicos de aprendizagem, como atenção, aquisição, memorização e transferência; (3) Reações ao Curso: satisfação dos participantes para com características instrucionais do curso e com o desempenho do tutor; e (4) Transferência de Treinamento: refere-se à aplicação dos CHAs aprendidos no curso no contexto de trabalho do participante. É medido em termos das respostas dos participantes à escala de frequência de aplicação do aprendido no curso no ambiente de trabalho, e as respostas dos participantes à pergunta "Você elaborou o plano de negócios ao final do curso?".

Outro modelo de avaliação foi desenvolvido por Sales (2009), por meio da proposição e testagem de um modelo estatístico de predição da situação de alunos (concluintes/evadidos) de treinamentos a distância, mediados pela web. Tal estudo, feito junto a estudantes egressos de treinamentos fornecidos pela Embrapa aos seus funcionários, incorporou ao modelo de investigação de Zerbini (2007) variáveis relacionadas ao contexto de estudo (ex. fatores situacionais ligados a problemas familiares e de saúde, ao trabalho, à falta de tempo), ao desenho do treinamento (ex. procedimentos instrucionais e desempenho do tutor), e ao próprio estudante (ex. disciplina e interesse e habilidades no manuseio de tecnologias da informação e comunicação). Desempenho do Tutor e Desenho do Curso referem-se ao primeiro conjunto de variáveis do instrumento desenvolvido, Disciplina e Interesse do Aluno 
e Experiências e Habilidades Importantes para Cursos a Distância, referem-se ao segundo bloco e Tempo Disponível para o Curso, Apoio no Trabalho e Questões Familiares estão relacionados às variáveis de contexto. Este instrumento será adaptado e utilizado na presente pesquisa, como destacado mais adiante.

O modelo avaliativo de ações instrucionais a distância elaborado por Martins (2012) se propôs a reconhecer elementos preditores de aprendizagem vinculados às características da clientela (Estratégias de Aprendizagem e frequência nos recursos da web) e às reações aos procedimentos instrucionais e ao tutor. Para tanto, a pesquisadora administrou presencial e virtualmente escalas de medida referentes a Estratégias de Aprendizagem, Reação aos procedimentos instrucionais e Reação ao desempenho do tutor junto a graduandos matriculados em disciplinas semipresenciais ofertadas a todos os estudantes da instituição parceira. A Figura 5 ilustra o modelo em questão.

1. Características da Clientela

1.1. Estratégias de Aprendizagem

1.2. Frequência nos recursos da web

2. Reações

2.1. Desempenho do Tutor

2.2. Procedimentos Instrucionais

Figura 5. Modelo de investigação proposto por Martins (2012).

Após a testagem do modelo, a autora verificou que a frequência de uso das ferramentas da web, as Estratégias de Aprendizagem Autorregulatórias e as Reações favoráveis aos Procedimentos Instrucionais explicaram a ocorrência de aprendizagem entre a amostra considerada. Dessa feita, Martins (2012) aponta para a relevância do ambiente virtual de aprendizagem, da comunicação tecida entre alunos e tutores, e da utilização de estratégias que promovam o autogerenciamento da aprendizagem e autorregulação da motivação, ansiedade e atenção, no alcance de resultados acadêmicos positivos, favorecendo o desempenho do alunado a distância.

Umekawa (2014) afirmou que o desenvolvimento dos docentes, a adaptação dos cursos ao ambiente de estudo dos alunos, o emprego adequado das novas ferramentas disponíveis, as estratégias de aprendizagem e hábitos de estudo do aprendiz são elementos que possivelmente se encontram relacionados aos desafios instrucionais e dificultam os retornos aos altos investimentos na implementação dessa modalidade de ensino. Seu modelo teórico fornece elementos que auxiliam na compreensão dos fatores que historicamente vêm sendo ligados ao 
abandono/persistência acadêmica no ensino não presencial. Para isso, a autora analisou as possíveis relações existentes entre a variável critério "Fatores Relacionados à Evasão e Persistência em EAD" (contexto de estudo, desenho do treinamento e características internas do estudante) e as variáveis antecedentes pertencentes às características da clientela (dados sociodemográficos e estratégias de aprendizagem). Tal modelo é demonstrado na figura 6.

1. Características da Clientela

1.2. Dados Sociodemográficos

1.1. Estratégias de Aprendizagem

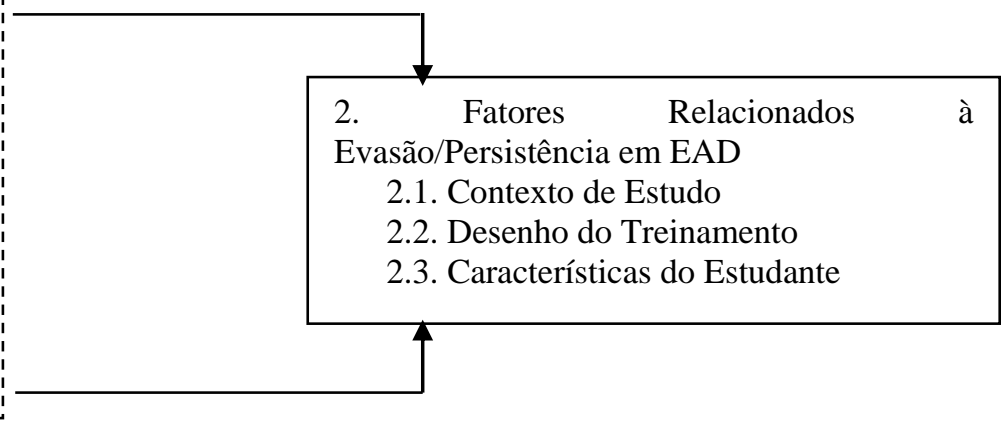

Figura 6. Modelo de investigação proposto por Umekawa (2014).

Nota-se que a autora destacou como um dos principais fatores relacionados à Evasão as características do Estudante. Nesse fator, pode-se incluir os Estilos e Estratégias de Aprendizagem, variáveis presentes nesse estudo.

Por fim, Brant (2014) propôs o "Modelo Teórico Multinível de Predição de Impacto de Treinamento a Distância no Trabalho e de Persistência/Evasão em Cursos Ofertados Nessa Modalidade" representado pela Figura 7. 


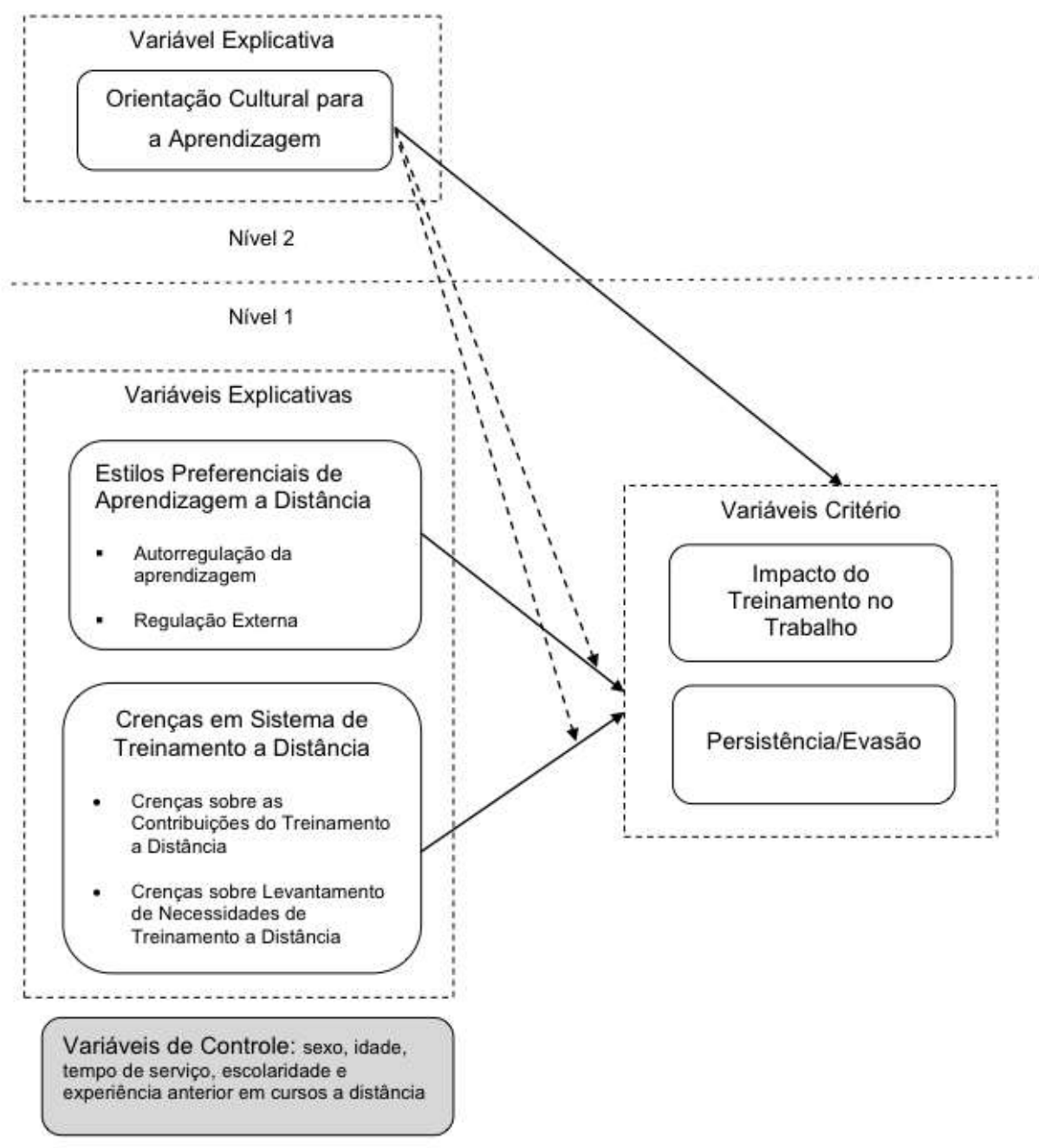

Figura 7. Modelo Teórico Multinível de Predição de Impacto de Treinamento a Distância no Trabalho e de Persistência/Evasão em Cursos Ofertados Nessa Modalidade” (Brant, 2014).

A figura 7 demonstra que a autora testou relações teóricas entre diferentes níveis de análise para a predição de impacto e de persistência/evasão. Foram controlados os efeitos de variáveis relacionadas ao perfil demográfico dos participantes. $\mathrm{O}$ nível 1 apresentou características individuais (Estilos de Aprendizagem e Crenças em Sistema de Treinamento a Distância) e o segundo nível apresentou uma característica organizacional denominada Orientação Cultural para a Aprendizagem. As variáveis critério inseridas foram o Impacto de Treinamento do Trabalho e a Persistência/Evasão da ação educacional. Os dados sociodemográficos (sexo, idade, escolaridade, tempo de serviço e experiência anterior em treinamentos a distância) foram consideradas variáveis de controle pertencentes ao nível individual (Nível 1).

Nota-se que a autora já incluiu em seu estudo a variável de Estilos de Aprendizagem como uma variável individual e explicativa para a Persistência/Evasão em ações educacionais 
ofertadas a distância em contexto de O\&T. Além disso, a autora também relaciona a variável com o Impacto no Treinamento do Trabalho, indicando que os Estilos de Aprendizagem podem influenciar nas percepções dos participantes sobre os efeitos produzidos pelo treinamento a distância.

Tendo em vista que os estudos realizados na seara da EAD e, em especial, aqueles que investigam os motivos da Evasão discente ainda são escassos e não conclusivos (Abbad et al., 2006; Sales, 2009, Umekawa, 2014), torna-se importante que venham a ser conduzidas pesquisas que incluam tal variável relacionando-a aos diversos elementos que circundam os cursos a distância). Assim, a presente pesquisa visa contribuir para com o campo de TD\&E ao fornecer elementos que podem auxiliar na compreensão das causas que levam os estudantes a evadirem cursos a distância.

Para uma maior compreensão dessa modalidade de ensino, é apresentada em seguida a caracterização da EAD, bem como sua inclusão em contextos de organizações e trabalho.

\subsection{Educação a Distância: Definições e Características}

O termo Educação a Distância, apesar de receber diversas conceptualizações (Vargas \& Abbad, 2006), pode ser concebido como uma abordagem de ensino-aprendizagem, mediada ou não por mídias tecnológicas, que torna possível a ocorrência de diferentes formas de interação entre professor-aluno e aluno-aluno (Associação Brasileira de Educação a Distância [ABED], 2012; Reis, 2009). Frente à presença de características singulares, tais como uma metodologia flexível e adaptada para indivíduos adultos, a EAD permite que discentes ajustem e conciliem seus estudos com outras atividades, sejam elas profissionais ou pessoais, exercendo, consequentemente, um controle mais intenso dos elementos tempo, espaço e ritmo de estudo (Döös \& Wilhelmson, 2011; Yukselturk \& Inan, 2006).

Todas as definições existentes guardam pontos em comum, apresentando uma anuência mínima em relação à EAD enquanto modalidade de ensino, cujas atividades ocorrem majoritariamente sem a necessidade da presença de professores e aprendizes no mesmo tempo e espaço (Associação Brasileira de Educação a Distância [ABED], 2012). De acordo com Walter (2006), as características elementares da EAD poderiam ser designadas como: (a) distanciamento físico entre professor e aluno; (b) processo de aprendizagem administrado pelo próprio discente e não pelo tutor, que neste contexto desempenha um papel auxiliar e facilitador; (c) relação professor-aluno sustentada por mídias tecnológicas diversas (televisão, internet, intranet, rádio, CD-ROM, material impresso são exemplos de tais recursos); e (d) 
maleabilidade de conteúdos a serem aprendidos (o aprendiz, de acordo com suas necessidades educativas, estrutura sua aprendizagem).

A expansão e o aprimoramento da área da tecnologia da informação e comunicação (TIC) em muito contribuiu para os diferenciados recursos e estratégias instrucionais empregados nos processos de ensino e aprendizagem. Tendo em conta as transformações sofridas pelo campo de TD\&E - decorrentes das inovações e melhorias cibernéticas (Aguinis \& Kraiger, 2009; Raymond e cols., 2014; Salas \& Cannon-Bowers, 2001) - a EAD está sendo considerada elemento apropriado a tal cenário renovador. Dispositivo estratégico nesta nova realidade instrucional, a EAD ao recorrer às avançadas mídias digitais e ferramentas de interação vem possibilitando que um contingente cada vez maior de indivíduos não só tenha acesso a conteúdos e informações, mas estabeleça contato apesar de possíveis distanciamentos físicos. Iglesias e Salgado (2012) apontam que as ferramentas das novas tecnologias de informação e comunicação (TICs) estão sendo tomadas como formas de reduzir custos financeiros, barateando os programas de treinamento, e estender o número de potenciais beneficiários das ações de TD\&E.

Cada vez mais a modalidade de EAD vem sendo empregada desde a Educação Básica até o Ensino Superior, passando também por programas de ensino não tradicionais - cursos de caráter aberto, por exemplo (Alves, 2011). Tal multiplicidade de uso talvez se deva, entre outras coisas, a efetividade de tais ações que, segundo apontamentos científicos, não se difere daquela encontrada em eventos educacionais presenciais. Ou seja, independente da modalidade de ensino considerada, quando corretamente delineada e implementada, a EAD pode produzir resultados análogos à educação face a face (Iglesias \& Salgado, 2012).

Apesar da introdução e do uso de ferramentas como a internet e o computador em contextos de ensino não remeterem a um passado muito longínquo, estes meios, com a popularização dos bens de consumo tecnológicos, vêm sendo massivamente empregados na EAD e impõem ao aluno a distância condições de estudo - ambiente de estudo transposto para o lar, acesso virtual a bibliotecas e demais serviços institucionais - e formas de se relacionar com seus pares (por meio de interações não presenciais) pouco presentes nas modalidades de ensino tradicionais e que podem afetar os resultados finais da ação educacional (Carvalho \& Abbad, 2006; Dean \& Webster, 2000; Moore \& Kearsley, 1996). As novas tecnologias de informação e comunicação atreladas a projetos de EAD expandem a possibilidade de acesso a programas de treinamento, formação e qualificação profissionais ofertados (Abbad, Carvalho \& Zerbini, 2006). 
Em relação ao papel desempenhado pelo docente na EAD, este pode ser considerado muito relevante, uma vez que a função de transmissor de informações é substituída por um papel mais complexo que deve primar pela (re)orientação dos processos de aprendizagem dos discentes empregando, para tanto, estratégias que se coadunem com os aprendizes (Litwin, 2001; Pereira, 2003). Além disso, o tutor deve instigar e incentivar os estudantes e fornecer feedbacks que venham a ser úteis na aquisição de competências (Appana, 2008; Pereira, 2003).

Um dos principais fatores impeditivos ou complicadores do desenvolvimento e êxito de cursos a distância seria a dificuldade apresentada pelos professores de manterem seus aprendizes atentos e engajados, tarefa esta considerada difícil já que o estudante na situação de EAD é circundado por um número maior de elementos distratores do que quando presente em sala de aula (Appana, 2008; Belloni, 1999). No contexto do modelo de ensino aqui tratado, é fundamental que o aluno não só domine as ferramentas tecnológicas, mas que se disponha a fazer uso dos instrumentais disponibilizados e tolere alguns aspectos inerentes à modalidade, tal como a limitação dos processos de interação professor-aluno e aluno-aluno (Palloff \& Pratt, 2004).

De acordo com o censo realizado pela ABED (2012), é visível o aumento vertiginoso que a EAD vem experimentando nas últimas décadas em solo nacional: durante o ano de 2009 o número total de indivíduos cursando algum tipo de programa instrucional não presencial atingiu a marca de 2.597.357 alunos. Este montante se encontra distribuído da seguinte forma: o número de alunos matriculados em ações educacionais em instituições credenciadas gira em torno de 901.274; cerca de 1.441.298 estudantes realizam cursos de caráter livre; e, cursos corporativos respondem por uma parcela de 254.785 discentes.

Apesar do crescente interesse pelos cursos ofertados a distância e do reconhecimento dos benefícios e vantagens dos mesmos, ainda restam graves hiatos na produção e sistematização dos conhecimentos da área de forma que análises e discussões que versem sobre ações educacionais a distância se fazem necessárias (Abbad, Carvalho \& Zerbini, 2006; Carvalho \& Abbad, 2006; Castro \& Ferreira, 2006; Martins, 2012, Umekawa, 2014; Zerbini, 2007).

A EAD em contextos organizacionais públicos e privados expande e populariza a entrada dos indivíduos no universo educacional e gera condições favoráveis à aprendizagem contínua (Abbad, 2007). Segundo dados do Anuário Brasileiro Estatístico de Educação Aberta e a Distância (ABRAEAD, 2007), a condição da EAD na educação corporativa brasileira apresenta alguns dos seguintes índices: 
- A clientela-alvo das ações educacionais ofertadas a distância pelas cem unidades de educação corporativa brasileiras é composta por funcionários diretos (59,30\%), funcionários indiretos e prestadores de serviços $(33,30 \%)$ e outros $(25,90 \%)$;

- As empresas focam principalmente o nível hierárquico operacional, uma vez que $85 \%$ delas ofertam seus cursos a distância para tal nível;

- Ações de EAD nas empresas visam principalmente o treinamento $(88,9 \%)$, seguido pela reciclagem $(51,9 \%)$ e aperfeiçoamento $(37,0 \%)$;

- Entre a diversificada gama de cursos a distância oferecida pelas organizações, os tipos mais frequentes são: informática $(12,40 \%)$, educação e cidadania $(12,10 \%)$ e gestão $(10,10 \%)$

- Os cursos a distância ministrados pelas empresas apresentam duração média de 41 horas (mínimo de 8 horas e máximo de 255 horas);

- O nível de adesão dos funcionários aos cursos a distância é considerado excelente $(33,3 \%)$ ou bom $(48,10 \%)$;

- O grau de satisfação dos funcionários com os cursos a distância é bastante positivo, de modo que a maior parte das avaliações atinge o conceito bom $(59,30 \%)$ ou excelente $(37 \%)$;

- As taxas de Evasão dos cursos nas empresas oscilam. Os dados revelam que 59,30\% das empresas registraram até $20 \%$ de Evasão, enquanto que $18,50 \%$ relataram Evasão de 20 a $30 \%$ e $22,20 \%$ das empresas atingiram um índice alarmante superior a $30 \%$.

Em virtude do importante papel que a Educação Corporativa vem assumindo em âmbito nacional, o Ministério da Educação, Ministério do Desenvolvimento, Indústria e Comércio Exterior e o Ministério do Trabalho e Emprego vêm aplicando recursos em programas de educação do trabalhador pelas organizações. Nesse sentido, o profissional brasileiro tem tido sua formação ocupacional estimulada pela utilização da EAD e pelo investimento na profusão de oportunidades de aprendizagem laboral continuada. Algumas das entidades que compõem o Sistema S - SESI, SENAI, SENAC e SEBRAE - se mostram cada vez mais comprometidas com a geração de possibilidades de formação profissional a distância, seja na forma pura ou híbrida de ações de ensino-aprendizagem, subsidiadas por diferentes mídias e tecnologias, tais como: ambientes virtuais de aprendizagem (AVAs), computadores, DVD, televisão e rádio (Umekawa, 2014). 
Ao analisar o Censo da Educação Superior de 2012 realizado pelo MEC, o ensino superior brasileiro apresenta uma evasão de $25,11 \%$. Por mais que novas universidades estejam sendo criadas, e novas vagas sendo abertas, além dos programas governamentais de acesso ao Ensino Superior, o número de concluintes do Ensino Superior é drasticamente inferior ao número de ingressantes. Esse dado é confirmado nos estudos realizados por Fritsch et al (2015), que tomando como base o censo do MEC referente ao período de 2010 a 2012 e puderam constatar o seguinte coeficiente de evasão na educação superior, respectivamente: 16.09\%; 18,81; e 25,11\%. Esses números, de acordo com estudos de Veloso e Maciel (2015) estão condicionados pelo aumento da demanda de acesso à Educação Superior no período.

Mesmo a EAD experimentando uma fase de expansão na educação corporativa a sua adoção é considerada recente em muitas instituições nacionais e novas práticas educacionais a distância ainda estão se consolidando em tal terreno (Abbad, 2007; ABRAEAD, 2007; Eboli, 2004).

Em relação à prevenção da evasão em cursos presenciais, Castro e Teixeira (2013) apontam a necessidade de ações antes mesmo do ingresso no Ensino Superior, como intervenções que alcancem crianças e adolescentes ainda na escola, e que divulguem questões como a importância do desenvolvimento de uma carreira, o desenvolvimento de habilidades necessárias ao mundo acadêmico e a importância de buscar informações sobre as profissões, além da própria exploração e reflexão sobre as características pessoais. Silva et al (2012) afirmam que o principal fator responsável pela evasão do grupo de alunos avaliados em sua pesquisa foi a escolha do curso de maneira equivocada e precipitada por parte do aluno, o que corrobora a necessidade de medidas preventivas antes do egresso de tais indivíduos nas IES.

Finalizada a apresentação do contexto de estudo, o próximo capítulo trata-se das variáveis que aparecem relacionadas aos Estilos de Aprendizagem: Evasão e Estratégias de Aprendizagem. 


\section{CAPÍTULO 2. VARIÁVEIS RELACIONADAS AOS ESTILOS DE APRENDIZAGEM: EVASÃO E ESTRATÉGIAS DE APRENDIZAGEM}

\section{Objetivo do capítulo 2}

O presente capítulo visa discutir sobre duas das principais variáveis relacionadas aos Estilos de Aprendizagem nos estudos em geral: Evasão e Estratégias de Aprendizagem. A primeira se justifica no sentido que um curso adaptado aos Estilos de Aprendizagem dos treinandos tende a ter um menor índice de Evasão. A segunda aparece muitas vezes comparada aos Estilos de Aprendizagem, fato que levou a um dos objetivos principais desse estudo: a validação convergente dos instrumentos que medem Estratégias e Estilos de Aprendizagem. Sendo assim, serão apresentadas as principais definições e estudos relacionados a Evasão e Estratégias de Aprendizagem, para facilitar o posterior estudo relacionando-as com os Estilos de aprendizagem.

\subsection{Evasão}

O MEC conceitua evasão como sendo a saída definitiva do curso de origem sem conclusão, ou a diferença entre ingressantes e concluintes, após uma geração completa. Quando faz referência a uma geração completa, o Ministério assume a ideia de que o tempo entre ingresso e conclusão é definido como o prazo máximo de conclusão do curso (Fritsch; Rocha \& Vitelli, 2015).

Baggi e Lopes (2010) afirmam que o tema de evasão escolar no ensino superior é um fenômeno complexo e, portanto, não pode ser analisado fora de um contexto histórico mais amplo, sendo reflexo da realidade de níveis anteriores de ensino, influenciando de diversas maneiras para o abandono de um curso superior.

A universidade, diante das transformações econômicas, políticas e culturais recentes que influenciam a educação, enfrenta a necessidade de repensar e transformar seus vínculos com a sociedade. É preciso corrigir alguns fatores e eliminar outros para que os estudantes possam ter, além do acesso à universidade, a garantia da conclusão do curso (Amaral, 2013).

O fenômeno da Evasão não é um problema recente e pontual no cenário educacional brasileiro e internacional (Amidani, 2004). A literatura nacional e estrangeira apresenta estudos desenvolvidos no campo da EAD voltados à investigação dos elevados índices de abandono em contextos de ensino superior e suas possíveis causas (Henke \& Hussum, 2000; Walter, 2006). Todavia, as lacunas observadas no que tange à investigação da Evasão em 
contextos educacionais a distância ainda são grandes e preocupantes, de modo que a realização de mais estudos sistemáticos sobre o fenômeno se faz preemente (Abbad et al., 2006; Brauer, 2005).

Mesmo sendo considerado um dos principais problemas da área de EAD, os resultados oriundos de pesquisas a respeito da Evasão em tais cenários de aprendizagem ainda são pouco conclusivos e de difícil generalização; parte dessa dificuldade pode ser atribuída à falta de consistência teórica do campo e à heterogeneidade de locais e instituições utilizadas nas investigações. Dados provenientes de revisões de literatura sobre o fenômeno chamam a atenção para os elevados índices de abandono em cursos a distância, alertando para a relevância desse problema: em cursos corporativos brasileiros a taxa de Evasão ultrapassa $30 \%$ (ABRAEAD, 2008), enquanto que na Ásia mais da metade dos alunos inscritos em programas de EAD não concluem seus estudos - na Europa os índices giram em torno de 50\% (Abbad at al., 2006; Shin \& Kim, 1999; Xenos et al., 2002).

No tocante as razões que levam o aluno a não concluir um programa de $\mathrm{EAD}$, a literatura indica motivos provenientes das características dos estudantes, das restrições inerentes aos contextos de estudo do participante e do desenho e execução do curso (Sales, 2009). Na presente pesquisa serão investigados os aspectos referentes às características do público-alvo (Estratégias de Aprendizagem, Estilos de Aprendizagem, perfil socioeconômico).

Os fatores referentes às características do público-alvo das ações educacionais a distância além de serem de extrema relevância para o planejamento de cursos em tal modalidade, também são vistos como relacionados à Evasão ou à persistência em EAD. Alguns destes fatores dizem respeito a: características demográficas e profissionais; conhecimentos anteriores acerca dos conteúdos tratados no curso; habilidade e experiência no uso de ferramentas e recursos eletrônicos de aprendizagem; disciplina do aluno; motivação para aprender; entre outros (Umekawa, 2014).

$O$ perfil do estudante de EAD é importante na medida em que denota tanto suas expectativas e necessidades específicas, bem como sinaliza alguns desafios impostos à efetividade de cursos dessa natureza; a tabela abaixo, formulada por Abbad (2007), indica essa realidade. 
Tabela 1. Perfil da clientela de EAD.

\begin{tabular}{|c|c|c|c|}
\hline O Aluno de EAD & $\begin{array}{c}\text { Expectativas e } \\
\text { Demandas }\end{array}$ & Desafios da EAD & $\begin{array}{c}\text { Potencialidades e Limitações } \\
\text { da EAD }\end{array}$ \\
\hline $\begin{array}{l}\text { É adulto com } \\
\text { múltiplas } \\
\text { experiências de vida. }\end{array}$ & $\begin{array}{l}\text { Espera que seus } \\
\text { conhecimentos e } \\
\text { experiências sejam } \\
\text { levados em conta ao } \\
\text { estudar. }\end{array}$ & $\begin{array}{l}\text { Escolher estratégias } \\
\text { participativas que } \\
\text { favoreçam o } \\
\text { aproveitamento dessas } \\
\text { experiências de vida no } \\
\text { processo de ensino- } \\
\text { aprendizagem. }\end{array}$ & $\begin{array}{l}\text { Uso de abordagens e } \\
\text { metodologias que facilitem a } \\
\text { criação de situações de } \\
\text { aplicação prática e resolução } \\
\text { de problemas. }\end{array}$ \\
\hline $\begin{array}{l}\text { Acumula diversos } \\
\text { papéis na sociedade. }\end{array}$ & $\begin{array}{l}\text { Espera que as } \\
\text { dificuldades de conciliar } \\
\text { responsabilidades } \\
\text { pessoais, profissionais e } \\
\text { de estudo sejam } \\
\text { percebidas e } \\
\text { consideradas pelos } \\
\text { profissionais } \\
\text { responsáveis pela } \\
\text { concepção e entrega de } \\
\text { soluções educacionais } \\
\end{array}$ & $\begin{array}{l}\text { Oportunidades de } \\
\text { estudar a qualquer hora } \\
\text { e em qualquer lugar. } \\
\text { Horários e tempos de } \\
\text { estudo flexíveis, } \\
\text { compatíveis com as } \\
\text { rotinas profissionais e } \\
\text { pessoais. } \\
\text { Interações assíncronas. }\end{array}$ & $\begin{array}{l}\text { Uso de recursos baseados nas } \\
\text { novas tecnologias da } \\
\text { informação para } \\
\text { armazenagem, acesso on-line a } \\
\text { objetos de aprendizagem e } \\
\text { comunicação assíncrona entre } \\
\text { os atores do processo de } \\
\text { ensino-aprendizagem. }\end{array}$ \\
\hline $\begin{array}{l}\text { Possui experiências } \\
\text { profissionais e busca } \\
\text { melhoria de status } \\
\text { socioeconômico. }\end{array}$ & $\begin{array}{l}\text { Necessita adquirir } \\
\text { competências } \\
\text { complementares e/ou } \\
\text { mais complexas que } \\
\text { aquelas que já possui. } \\
\text { Espera situações de } \\
\text { aprendizagem } \\
\text { compatíveis com seu } \\
\text { perfil profissional e que } \\
\text { tenham impacto } \\
\text { favorável sobre a vida } \\
\text { profissional. }\end{array}$ & $\begin{array}{l}\text { Necessita de situações } \\
\text { de aprendizagem que } \\
\text { elevem as suas } \\
\text { competências em } \\
\text { termos de } \\
\text { complexidade e } \\
\text { relevância prática. } \\
\text { Situações de } \\
\text { aprendizagem } \\
\text { derivadas da } \\
\text { experiência do aluno, } \\
\text { que reforcem a sua } \\
\text { identidade e carreira } \\
\text { profissional. }\end{array}$ & $\begin{array}{l}\text { Desenho baseado na } \\
\text { avaliação do perfil } \\
\text { profissional do público- } \\
\text { alvo. } \\
\text { Flexibilidade na } \\
\text { sequência de } \\
\text { apresentação de } \\
\text { conteúdos. } \\
\text { Pré-teste para ingresso } \\
\text { no curso e em cada parte } \\
\text { do mesmo. } \\
\text { Possibilidade de } \\
\text { orientação e feedback } \\
\text { individualizados. } \\
\text { Condições propícias para } \\
\text { a criação de exercícios } \\
\text { que requeiram respostas } \\
\text { abertas e solução de } \\
\text { problemas relacionados } \\
\text { às atividades } \\
\text { profissionais do aluno. }\end{array}$ \\
\hline $\begin{array}{l}\text { É profissionalmente } \\
\text { ativo. }\end{array}$ & $\begin{array}{l}\text { Espera que as mídias de } \\
\text { entrega dos conteúdos e } \\
\text { os recursos de apoio } \\
\text { sejam compatíveis e } \\
\text { adequados às rotinas de } \\
\text { trabalho. }\end{array}$ & $\begin{array}{l}\text { Utilização de múltiplas } \\
\text { mídias e serviços de } \\
\text { tutoria e monitoria } \\
\text { compatíveis com } \\
\text { horários de estudo. }\end{array}$ & $\begin{array}{l}\text { Há mídias mais ou menos } \\
\text { flexíveis e nem todas são } \\
\text { adequadas ao tipo de objetivo } \\
\text { educacional do curso. }\end{array}$ \\
\hline $\begin{array}{l}\text { É mais qualificado } \\
\text { que estudantes de } \\
\text { cursos presenciais. }\end{array}$ & $\begin{array}{l}\text { Espera não ter que } \\
\text { memorizar informações } \\
\text { pouco complexas e } \\
\text { disponíveis no contexto } \\
\text { de estudo e de trabalho. } \\
\text { Necessita solucionar } \\
\text { problemas reais e } \\
\text { relevantes. }\end{array}$ & $\begin{array}{l}\text { Criar ambientes } \\
\text { interativos de } \\
\text { aprendizagem. } \\
\text { Criar situações em que } \\
\text { a participação ativa o } \\
\text { aluno é decisiva para a } \\
\text { solução de problemas } \\
\text { ligados ao contexto de } \\
\text { estudo. }\end{array}$ & $\begin{array}{l}\text { Uso de simuladores e de } \\
\text { metodologias baseadas em } \\
\text { resolução colaborativa de } \\
\text { problemas, webquests, entre } \\
\text { outros, são possíveis. Porém, } \\
\text { os custos iniciais para o } \\
\text { desenvolvimento desse tipo de } \\
\text { tecnologia são altos. }\end{array}$ \\
\hline
\end{tabular}


Tabela 1. Perfil da clientela de EAD (continuação)

\begin{tabular}{|c|c|c|c|}
\hline O Aluno de EAD & $\begin{array}{c}\text { Expectativas e } \\
\text { Demandas }\end{array}$ & Desafios da EAD & $\begin{array}{c}\text { Potencialidades e Limitações } \\
\text { da EAD }\end{array}$ \\
\hline $\begin{array}{l}\text { Valoriza o estudo em } \\
\text { função de ciclos e } \\
\text { planos de vida. É } \\
\text { motivado para a } \\
\text { aprendizagem. }\end{array}$ & $\begin{array}{l}\text { Espera ter experiências } \\
\text { de estudo que facilitem o } \\
\text { alcance de objetivos } \\
\text { profissionais e pessoais. }\end{array}$ & $\begin{array}{l}\text { Compatibilizar as } \\
\text { características do curso } \\
\text { ao perfil motivacional } \\
\text { do aluno (produtos e } \\
\text { competências } \\
\text { resultantes do curso } \\
\text { valorizadas pela } \\
\text { clientela). }\end{array}$ & $\begin{array}{l}\text { Possibilidade de uso de } \\
\text { inteligência artificial para } \\
\text { adequação do desenho do } \\
\text { curso ao aluno. } \\
\text { Limitação: essas Tecnologias } \\
\text { ainda são pouco acessíveis. }\end{array}$ \\
\hline $\begin{array}{l}\text { Luta contra a } \\
\text { obsolescência } \\
\text { profissional. }\end{array}$ & $\begin{array}{l}\text { Necessita atualizar-se e } \\
\text { se requalificar de modo } \\
\text { contínuo, ao longo de } \\
\text { toda a vida. }\end{array}$ & $\begin{array}{l}\text { Armazenar, indexar e } \\
\text { disponibilizar } \\
\text { informações relevantes, } \\
\text { mecanismos de } \\
\text { orientação profissional } \\
\text { e trilhas de } \\
\text { aprendizagem. }\end{array}$ & $\begin{array}{l}\text { Uso de plataformas eletrônicas } \\
\text { de gerenciamento da } \\
\text { aprendizagem. } \\
\text { Acesso a bibliotecas virtuais. } \\
\text { Acesso e estímulo a formação } \\
\text { de comunidades virtuais de } \\
\text { aprendizagem. }\end{array}$ \\
\hline
\end{tabular}

Fonte: Abbad (2007).

Pode-se perceber que o aluno de EAD busca um aprimoramento profissional e uma melhoria de sua condição socioeconômica. Sendo assim, costuma ser motivado para a aprendizagem. Por outro lado, por serem profissionalmente ativos, possuem pouco tempo disponível. Buscam, em seus estudos, solucionar problemas reais e relevantes, conectados com sua prática profissional. O desafio da EAD está em acompanhar o perfil desse aluno, com suas necessidades e expectativas. O ensino deve ser dinâmico, através dos ambientes virtuais de aprendizagem (AVA), relacionando o conteúdo à pratica profissional e tornando o aluno ativo no processo de aprendizagem. Para isso, o uso das TICs torna-se essencial.

Variáveis cognitivas e motivacionais dos estudantes a distância também são consideradas de grande relevância, de modo que não basta deter recursos autorregulatórios, mas é fundamental conseguir empregá-los constantemente frente a dificuldades, elementos estressantes ou interesses concorrentes (Zimmerman \& Bandura, 1994). Segundo Souza (2010), diversas crenças pessoais interferem no desempenho e motivação dos aprendizes, sejam essas autorreferenciais ou relacionadas ao objeto de conhecimento. Dentre tais fatores, a autoeficácia e locus de controle vêm sendo pesquisados como elementos associados ao desempenho acadêmico (Abbad \& Meneses, 2004; Altman \& Arambasich, 1982; Parker, 1995; Zerbini, 2007).

A persistência do aprendiz online depende não apenas de qualidades acadêmicas ou ambientais, mas também de níveis elevados de motivação estudantil (Holder, 2007; Morris, Finnegan, \& Wu, 2005). O aspecto motivacional é considerado como fator primário em qualquer modelo ou teoria de aprendizagem. Abbad, Pantoja e Pilati (2003) apontam para 
uma confusão conceitual que envolve esse constructo, oriunda dos diminutos esforços de pesquisa a fim de saná-la, de modo que essa variável é ora compreendida como causa ora como razão do desempenho humano.

Para esse trabalho, foi analisada a revisão de literatura produzida por Umekawa (2014). A autora realizou um levantamento bibliográfico nas bases de dados tidas como relevantes em revisões de TD\&E, considerando as obras produzidas no período de 2005 a 2012. Tal revisão bibliográfica objetivou verificar os progressos no campo dos aspectos ligados tanto ao abandono acadêmico quanto à persistência em EAD, bem como descrever os achados de pesquisa acerca do tópico Evasão escolar. A seguir, segue a Tabela 2, resultante do levantamento bibliográfico realizado por Umekawa (2014). 
Tabela 2. Resultados de pesquisas nacionais e internacionais sobre "Evasão e Persistência em EAD".

\begin{tabular}{|c|c|c|c|c|c|}
\hline Autores & Objetivo & Amostra/Contexto & $\begin{array}{l}\text { Procedimentos de } \\
\text { coleta de dados }\end{array}$ & $\begin{array}{c}\text { Procedimentos } \\
\text { de análise de } \\
\text { dados }\end{array}$ & Resultados \\
\hline Shin e Kim (1999) & $\begin{array}{l}\text { Avaliar uma série de } \\
\text { variáveis, endógenas e } \\
\text { exógenas, ligadas a cursos } \\
\text { não presenciais. }\end{array}$ & $\begin{array}{l}4.668 \text { estudantes da } \\
\text { Universidade } \\
\text { Nacional Aberta da } \\
\text { Coréia }\end{array}$ & $\begin{array}{l}\text { - Questionário } \\
\text { composto por } 20 \\
\text { questões referentes às } \\
\text { variáveis endógenas - } \\
\text { (1) tempo dedicado ao } \\
\text { estudo; (2) } \\
\text { planejamento e } \\
\text { organização dos } \\
\text { processos de } \\
\text { aprendizagem; (3) } \\
\text { atividades e contato } \\
\text { pessoal dos alunos - e } \\
\text { exógenas - (1) carga de } \\
\text { trabalho; (2) incentivo } \\
\text { social para a realização } \\
\text { do curso; (3) desejo de } \\
\text { completar o evento } \\
\text { educacional. }\end{array}$ & $\begin{array}{l}\text { Análises de } \\
\text { regressão } \\
\text { logística; }\end{array}$ & $\begin{array}{l}\text { - Os autores chamam a atenção para a necessidade } \\
\text { de se repensar o papel que encontros presenciais } \\
\text { desempenham na EAD, uma vez que apenas a } \\
\text { variável endógena "atividades e contato pessoal } \\
\text { dos alunos" foi relacionada com o fenômeno da } \\
\text { Evasão. }\end{array}$ \\
\hline e Hussum & $\begin{array}{l}\text { Identificar fatores diversos } \\
\text { que contribuiriam para a } \\
\text { ocorrência de Evasão em } \\
\text { programas corporativos de } \\
\text { EAD. }\end{array}$ & $\begin{array}{l}62 \text { estudantes } \\
\text { evadidos de dois } \\
\text { cursos corporativos } \\
\text { ofertados por meio do } \\
\text { LMS Learning Space } \\
\text { nos continentes } \\
\text { europeu, asiático e } \\
\text { americano }\end{array}$ & $\begin{array}{l}\text { - Questionário (12 } \\
\text { perguntas a serem } \\
\text { respondidas em uma } \\
\text { escala Likert de } 5 \\
\text { pontos) relativo a } \\
\text { possíveis causas da } \\
\text { Evasão }\end{array}$ & $\begin{array}{l}\text { Análises } \\
\text { correlacionais; }\end{array}$ & $\begin{array}{l}\text { - Inexistência de correlações significativas entre as } \\
\text { variáveis analisadas; } \\
\text { - A principal razão apontada para a não finalização } \\
\text { do curso foi a dificuldade em conciliá-lo com } \\
\text { outros compromissos profissionais; }\end{array}$ \\
\hline
\end{tabular}


Tabela 2. Resultados de pesquisas nacionais e internacionais sobre "Evasão e Persistência em EAD” (continuação).

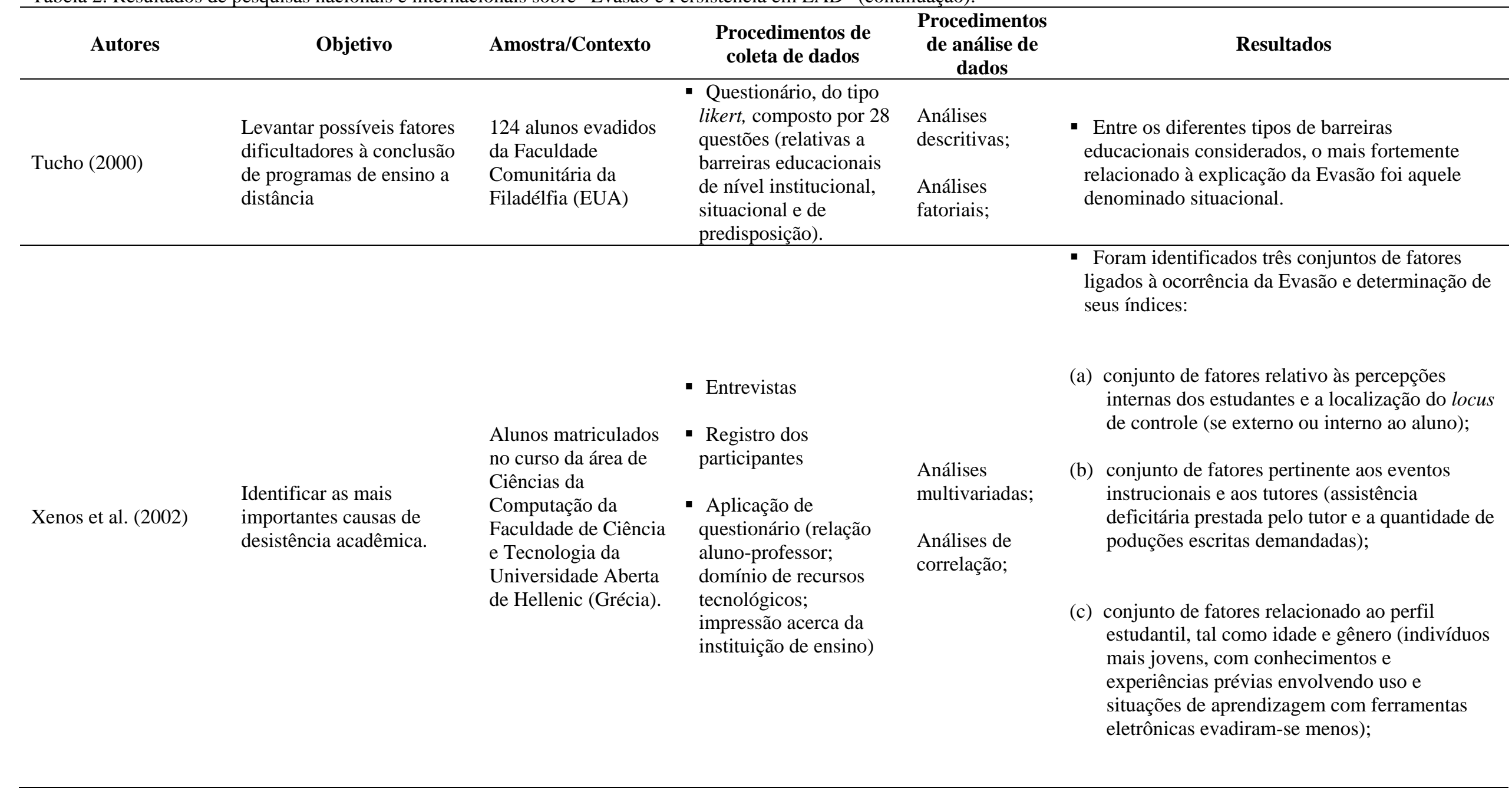


Tabela 2. Resultados de pesquisas nacionais e internacionais sobre "Evasão e Persistência em EAD" (continuação)

\begin{tabular}{|c|c|c|c|c|c|}
\hline Autores & Objetivo & Amostra/Contexto & $\begin{array}{l}\text { Procedimentos de } \\
\text { coleta de dados }\end{array}$ & $\begin{array}{c}\text { Procedimentos } \\
\text { de análise de } \\
\text { dados }\end{array}$ & Resultados \\
\hline Coelho (2003) & $\begin{array}{l}\text { Reconhecer elementos } \\
\text { favorecedores da } \\
\text { permanência discente, bem } \\
\text { como fatores causais de } \\
\text { Evasão, em ações } \\
\text { educacionais ofertadas a } \\
\text { distância via internet }\end{array}$ & $\begin{array}{l}\text { Estudo de caso } \\
\text { envolvendo } 37 \\
\text { profissionais } \\
\text { participantes } \\
\text { (concluintes ou não) } \\
\text { de um programa de } \\
\text { formação continuada } \\
\text { para professores } \\
\text { universitários }\end{array}$ & $\begin{array}{l}\text { Questionário de } \\
\text { questões de múltipla } \\
\text { escolha (identificação } \\
\text { pessoal, informações } \\
\text { referentes ao curso, e } \\
\text { razões para a } \\
\text { conclusão/abandono do } \\
\text { curso }\end{array}$ & $\begin{array}{l}\text { Análises } \\
\text { descritivas; }\end{array}$ & $\begin{array}{l}\text { - Foram identificadas diferenças entre a amostra } \\
\text { de participantes concluintes e de evadidos em } \\
\text { relação às seguintes variáveis: idade, sexo, } \\
\text { formação acadêmica. } \\
\text { - Evadidos e concluintes consideraram como } \\
\text { principal causa da Evasão a limitação de tempo } \\
\text { para o desenvolvimento do curso. } \\
\text { - Outras causas do abandono acadêmico também } \\
\text { citados foram: condições inapropriadas de estudo } \\
\text { em casa, local de trabalho sem ambiente } \\
\text { adequado para estudo, desorganização pessoal, } \\
\text { dificuldades técnicas, e falta de correspondência } \\
\text { com as expectativas traçadas. }\end{array}$ \\
\hline Wang et al. (2003) & $\begin{array}{l}\text { Refletir acerca das } \\
\text { experiências e desafios } \\
\text { enfrentados por } \\
\text { profissionais e alunos } \\
\text { atuantes no campo da EAD } \\
\text { em contextos de } \\
\text { organizações e trabalho }\end{array}$ & $\begin{array}{l}388 \text { indivíduos - } 13 \\
\text { profissionais } \\
\text { responsáveis pela } \\
\text { gerência de cursos e } \\
375 \text { estudantes -dos } \\
\text { EUA envolvidos com } \\
\text { o e-learning }\end{array}$ & $\begin{array}{l}\text { - Entrevistas } \\
\text { - Aplicação de } \\
\text { questionário } \\
\text { (experiências } \\
\text { vivenciadas pelos } \\
\text { alunos em ações } \\
\text { instrucionais a } \\
\text { distância) }\end{array}$ & $\begin{array}{l}\begin{array}{l}\text { Análises } \\
\text { descritivas; }\end{array} \\
\text { Análises de } \\
\text { correlação; } \\
\text { Análises de } \\
\text { conteúdo; }\end{array}$ & $\begin{array}{l}\text { - Fatores que contribuem para a permanência em } \\
\text { EAD: motivação pessoal (citada por } 73 \% \text { dos } \\
\text { participantes); interações de aprendizagem } \\
\text { satisfatórias ( } 40 \%) \text {; políticas organizacionais de } \\
\text { conclusão obrigatória ( } 28.5 \%) \text {; e, } \\
\text { acompanhamento virtual dos professores (16\%); } \\
\text { - Fatores que influenciam os índices de Evasão: } \\
\text { falta de motivação do aprendiz (36\%); desenho } \\
\text { instrucional e incompatibilidade com os Estilos de } \\
\text { Aprendizagem (36\%); escassez de tempo em } \\
\text { virtude de compromissos familiares e laborais } \\
\text { (33.1\%); domínio dos conhecimentos e habiliades } \\
\text { necessários ao desempenho profissional antes do } \\
\text { término do curso (25\%); falta de suporte } \\
\text { organizacional (25\%); }\end{array}$ \\
\hline
\end{tabular}


Tabela 2. Resultados de pesquisas nacionais e internacionais sobre "Evasão e Persistência em EAD” (continuação).

\begin{tabular}{|c|c|c|c|c|c|}
\hline Autores & Objetivo & Amostra/Contexto & $\begin{array}{l}\text { Procedimentos de } \\
\text { coleta de dados }\end{array}$ & $\begin{array}{l}\text { Procedimentos } \\
\text { de análise de } \\
\text { dados }\end{array}$ & Resultados \\
\hline Amidani (2004) & $\begin{array}{l}\text { Investigar a Evasão } \\
\text { acadêmica no contexto } \\
\text { brasileiro de ensino } \\
\text { superior a distância. }\end{array}$ & $\begin{array}{l}174 \text { alunos do curso } \\
\text { de Licenciatura em } \\
\text { Matemática } \\
\text { ministrado pelo } \\
\text { Centro de Educação } \\
\text { Superior a Distância } \\
\text { do Estado do Rio de } \\
\text { Janeiro. }\end{array}$ & $\begin{array}{l}\text { - Entrevistas (com } \\
\text { tutores, alunos } \\
\text { concluintes, alunos não } \\
\text { concluintes, direção de } \\
\text { polo e direção de } \\
\text { produção do material } \\
\text { didático) } \\
\text { - Questionário }\end{array}$ & $\begin{array}{l}\text { Análise } \\
\text { qualitativas (de } \\
\text { conteúdo); }\end{array}$ & $\begin{array}{l}\text { - Os resultados indicaram a importância da } \\
\text { integração acadêmica do discente, uma vez que os } \\
\text { estudantes concluintes se disseram satisfeitos com } \\
\text { o desempenho dos tutores e com o conteúdo } \\
\text { transmitido. } \\
\text { - Dificuldades em conciliar atividades discentes e } \\
\text { compromissos de outra natureza (familiares, } \\
\text { profissionais, sociais), pressões laborais e pouco } \\
\text { contato prévio com a EAD também foram } \\
\text { considerados como prejudiciais à permanência do } \\
\text { estudante. }\end{array}$ \\
\hline
\end{tabular}

- Questionário semiestruturado $(23$ questões abertas e fechadas) versando

70 tutores do

Compreender a Evasão no

Ngoma et al. (2004) contexto universitário de

ensino programa de extensão

da Universidade de

Estudos de Extensão

de Zâmbia sobre informações

pessoais dos tutores,

qualificações

profissionais possuídas

e fatores considerados

como causadores de

Evasão
Análises descritivas;

Análises

qualitativas;
- Variáveis pouco interferentes nos índices de Evasão: qualificação dos tutores; conteúdos do curso e custos do evento educacional;

- Variáveis altamente interferentes nos índices de abando estudantil: compromissos e tarefas não relacionados ao curso e dificuldades em contatar os tutores. 
Tabela 2. Resultados de pesquisas nacionais e internacionais sobre "Evasão e Persistência em EAD” (continuação).

\begin{tabular}{|c|c|c|c|c|c|}
\hline Autores & Objetivo & Amostra/Contexto & $\begin{array}{l}\text { Procedimentos de } \\
\text { coleta de dados }\end{array}$ & $\begin{array}{l}\text { Procedimentos } \\
\text { de análise de } \\
\text { dados }\end{array}$ & Resultados \\
\hline $\begin{array}{l}\text { Pierrakeas et al. } \\
\text { (2004) }\end{array}$ & $\begin{array}{l}\text { Investigar os efeitos da } \\
\text { natureza do evento } \\
\text { instrucional sobre a Evasão } \\
\text { ou a persistência em EAD }\end{array}$ & $\begin{array}{l}\text { Alunos (evadidos ou } \\
\text { concluintes) de dois } \\
\text { cursos a distância } \\
\text { ofertados - um deles } \\
\text { de bacharelado e o } \\
\text { outro de pós- } \\
\text { graduação - pela } \\
\text { universidade aberta } \\
\text { Hellenic Open } \\
\text { University (Grécia) }\end{array}$ & $\begin{array}{l}\text { - Análise documental } \\
\text { (sistema de registro da } \\
\text { instituição) } \\
\text { - Anotações redigidas } \\
\text { pelos tutores dos cursos } \\
\text { - Entrevistas junto a } \\
\text { discentes evadidos }\end{array}$ & $\begin{array}{l}\text { Análises } \\
\text { multivariadas; } \\
\text { Análise de } \\
\text { conteúdo; }\end{array}$ & $\begin{array}{l}\text { - A subestimação do tempo requerido para o } \\
\text { cumprimento do curso e das demais atividades } \\
\text { paralelas aparece entre as mais frequentes causas } \\
\text { mencionadas para a desistência discente; } \\
\text { - Os resultados obtidos apontaram para uma } \\
\text { possível relação positiva entre idade e índice de } \\
\text { Evasão. } \\
\text { - Nesse estudo, a variável sexo não esteve } \\
\text { - significativamente ligada ao abandono estudantil. } \\
\text { - Índices de Evasão mais elevados no curso de } \\
\text { graduaçãa em comparação ao curso de pós- } \\
\text { graduação indicam que indivíduos ambientados às } \\
\text { exigências próprias do meio educacional } \\
\text { apresentam menor propensão a evadirem-se do } \\
\text { que aqueles inexperientes; }\end{array}$ \\
\hline Vargas (2004) & $\begin{array}{l}\text { Avaliar barreiras à } \\
\text { proposição de programas } \\
\text { instrucionais ofertados a } \\
\text { distância }\end{array}$ & $\begin{array}{l}\text { Funcionários de } \\
\text { grande empresa } \\
\text { atuante no ramo } \\
\text { elétrico }\end{array}$ & $\begin{array}{l}\text { Entrevistas semi- } \\
\text { estruturadas } \\
\text { - Aplicação de } \\
\text { questionários (MSLQ e } \\
\text { Reações à Tecnologia) }\end{array}$ & $\begin{array}{l}\text { Análises de } \\
\text { conteúdo; } \\
\text { Análises de } \\
\text { correlação; } \\
\text { Análises de } \\
\text { regressão } \\
\text { logística; } \\
\begin{array}{l}\text { Análises de } \\
\text { regressão linear } \\
\text { padrão; }\end{array}\end{array}$ & $\begin{array}{l}\text { - Análises de regressão logística, tendo como } \\
\text { variáveis antecedentes dados demográficos, } \\
\text { motivacionais e tecnológicos e variável critério } \\
\text { permanência, apontam para um significativo } \\
\text { relacionamento entre a variável critério e gênero e } \\
\text { crenças de aprendizagem; } \\
\text { - A amostra utilizada considerou como uma das } \\
\text { principais causas de abandono acadêmico } \\
\text { dificuldades relacionadas à atuação do professor; }\end{array}$ \\
\hline
\end{tabular}


Tabela 2. Resultados de pesquisas nacionais e internacionais sobre "Evasão e Persistência em EAD" (continuação).

\begin{tabular}{|c|c|c|c|c|c|}
\hline Autores & Objetivo & Amostra/Contexto & $\begin{array}{l}\text { Procedimentos de } \\
\text { coleta de dados }\end{array}$ & $\begin{array}{l}\text { Procedimentos } \\
\text { de análise de } \\
\text { dados }\end{array}$ & Resultados \\
\hline Brauer (2005) & $\begin{array}{l}\text { Verificar o poder } \\
\text { explicativo das variáveis } \\
\text { antecedentes características } \\
\text { da clientela e barreiras } \\
\text { pessoais à conclusão do } \\
\text { curso sobre Evasão em } \\
\text { cursos a distância }\end{array}$ & $\begin{array}{l}\text { Indivíduos inscritos } \\
\text { (15889) no curso } \\
\text { Iniciando um } \\
\text { Pequeno Grande } \\
\text { Negócio (IPGN) } \\
\text { ministrado } \\
\text { virtualmente pelo } \\
\text { Sebrae }\end{array}$ & $\begin{array}{l}\text { - Escala de "Valor } \\
\text { Instrumental do } \\
\text { Treinamento" } \\
\text { - Escala de "Barreiras } \\
\text { Pessoais à Conclusão } \\
\text { do Curso"; }\end{array}$ & $\begin{array}{l}\text { Análises de } \\
\text { regressões } \\
\text { logísticas; } \\
\text { Análises de } \\
\text { regressão } \\
\text { múltipla padrão } \\
\text { stepwise; }\end{array}$ & $\begin{array}{l}\text { - Os modelos testados apresentaram reduzido poder } \\
\text { explicativo, sustentando a hipótese de que dados } \\
\text { demográficos guardam baixa capacidade preditiva } \\
\text { sobre variáveis de resultados de treinamento. }\end{array}$ \\
\hline $\begin{array}{l}\text { Abbad, Carvalho e } \\
\text { Zerbini (2006) }\end{array}$ & $\begin{array}{l}\text { Avaliar fatores } \\
\text { explicativos de Evasão em } \\
\text { uma ação instrucional } \\
\text { gratuita ofertada } \\
\text { totalmente a distância }\end{array}$ & $\begin{array}{l}\text { População de alunos } \\
\text { ( } \mathrm{n}=19.849 \text { ) inscritos } \\
\text { em um curso que } \\
\text { objetivava a } \\
\text { elaboração de um } \\
\text { plano de negócios }\end{array}$ & $\begin{array}{l}\text { Consideração dos três } \\
\text { componentes, (1) } \\
\text { Características } \\
\text { Demográficas da } \\
\text { Clientela; (2) Uso dos } \\
\text { Recursos Eletrônicos } \\
\text { do Curso e (3) Evasão, } \\
\text { presentes no modelo de } \\
\text { pesquisa proposto }\end{array}$ & $\begin{array}{l}\text { Análises } \\
\text { descritivas } \\
\text { Análises } \\
\text { exploratórias; }\end{array}$ & $\begin{array}{l}\text { - Os participantes que menos frequentemente } \\
\text { acessaram os chats, o mural de notícias e o } \\
\text { ambiente virtual do curso foram aqueles que mais } \\
\text { tenderam à Evasão. Os resultados indicam } \\
\text { possíveis relações entre frequência de uso das } \\
\text { ferramentas eletrônicas e Evasão em contextos de } \\
\text { e-learning; }\end{array}$ \\
\hline $\begin{array}{l}\text { Favero e Franco } \\
(2006)\end{array}$ & $\begin{array}{l}\text { Investigar o papel } \\
\text { desempenhado pelas } \\
\text { interações estabelecidas } \\
\text { entre aprendizes em } \\
\text { contextos de aprendizagem } \\
\text { online }\end{array}$ & $\begin{array}{l}\text { Trocas ocorridas } \\
\text { entre os participantes } \\
\text { de curso ofertado } \\
\text { pelo Ambiente } \\
\text { Teleduc, bem como o } \\
\text { AVA e comunidades } \\
\text { virtuais utilizados } \\
\text { pelos mesmos }\end{array}$ & $\begin{array}{l}\text { Análise das interações } \\
\text { ocorridas entre os } \\
\text { alunos durante a } \\
\text { aprendizagem por meio } \\
\text { do uso das ferramentas } \\
\text { de comunicação } \\
\text { disponibilizadas (como } \\
\text { fóruns, chats, e-mails, } \\
\text { diários de bordo e } \\
\text { mural) }\end{array}$ & $\begin{array}{l}\text { Análises } \\
\text { descritivas; } \\
\text { Análises } \\
\text { qualitativas; }\end{array}$ & $\begin{array}{l}\text { - No estudo, os estudantes concluintes foram } \\
\text { aqueles que mais se mostraram solícitos e } \\
\text { cooperaram ao longo das interações estabelecidas } \\
\text { no curso e manifestavam a aquisição de } \\
\text { conhecimentos transmitidos. }\end{array}$ \\
\hline
\end{tabular}


Tabela 2. Resultados de pesquisas nacionais e internacionais sobre "Evasão e Persistência em EAD” (continuação).

Amostra/Contexto $\quad \begin{array}{cc}\text { Procedimentos de } & \begin{array}{c}\text { Procedimentos } \\ \text { de análise de }\end{array}\end{array}$

Autores

Objetivo

coleta de dados

dados

Investigar as causas e

situações mais frequentes

relacionadas ao abandono

acadêmico
230 indivíduos

evadidos do curso

ofertado virtualmente

pela Escola de Saúde

Pública (ESP) do

estado do Ceará
- Questionário semiestruturado questões abertas fechadas - relativo a fatores que

contribuíram para saída do curso

Resultados

- O estudo aponta como principais causas da

Evasão:

(a) variáveis relacionadas ao desenho instrucional do curso (ex, dificuldades de encontrar

Tabulação dos dados por meio

do software

EPIINFO 6.04 informações no AVA, proposição de exercícios pouco didáticos);

(b) experiência e habilidade limitada com a estrutura tecnológica do curso;

(c) o estudo solitário;

(d) desmotivação;

(e) escassez de tempo;

- Elementos favoráveis à conclusão do curso: a criação de um plano de estudo; organização e definição de horários específicos para realização das atividades pertinentes ao curso; leitura de materiais a respeito das características do curso; conciliação de compromissos familiares, profissionais e acadêmicos; incentivo e organização familiar para o desenvolvimento do

1.494 estudantes (concluintes e

Identificar os elementos preditores de Evasão em cursos não presenciais

de Mediação e

Arbitragem, e
- Escala de

"Comportamentos e

Atitudes do Aluno em

Relação a Cursos a

Distância"

Formação de

Consultores do

Projeto Empreender

- Escala de "Valor Instrumental do

Treinamento, no
Análises

estatística

exploratórias;

Análises

descritivas; âmbito da Educação a

Distância";
Análises inferenciais;

Análise qualitativas
- Elementos desfavoráveis à conclusão do curso: distanciamento físico entre os atores envolvidos; falta de contato visual; não ocorrência de aulas presenciais; complexidade do conteúdo do curso; habilidade de uso dos recursos tecnológicos limitada. 
Tabela 2. Resultados de pesquisas nacionais e internacionais sobre "Evasão e Persistência em EAD” (continuação).

\begin{tabular}{|c|c|c|c|c|c|c|}
\hline Autores & & Objetivo & Amostra/Contexto & $\begin{array}{l}\text { Procedimentos de } \\
\text { coleta de dados }\end{array}$ & $\begin{array}{c}\text { Procedimentos } \\
\text { de análise de } \\
\text { dados }\end{array}$ & Resultados \\
\hline $\begin{array}{l}\text { Yukselturk e } \\
(2006)\end{array}$ & Inan & $\begin{array}{l}\text { Investigar possíveis fatores } \\
\text { relacionados a Evasão em } \\
\text { um programa virtual de } \\
\text { formação superior }\end{array}$ & $\begin{array}{l}98 \text { estudantes } \\
\text { evadidos do } \\
\text { Programa de } \\
\text { Certificação em } \\
\text { Tecnologia da } \\
\text { Informação (Turquia) }\end{array}$ & $\begin{array}{l}\text { Questionário de } \\
\text { concordância do tipo } \\
\text { likert de } 5 \text { pontos } \\
\text { composto por } 14 \\
\text { questões relacionadas } \\
\text { às principais razões } \\
\text { para o abandono } \\
\text { acadêmico }\end{array}$ & $\begin{array}{l}\text { Análises } \\
\text { descritivas; } \\
\text { Análises de } \\
\text { conteúdo; }\end{array}$ & $\begin{array}{l}\text { - As principais causas de Evasão foram } \\
\text { relacionadas à insuficiência de tempo para } \\
\text { desenvolvimento do curso, problemas pessoais } \\
\text { (doenças, compromissos profissionais, demandas } \\
\text { familiares, etc.) e queda na motivação. }\end{array}$ \\
\hline Almeida (2007) & & $\begin{array}{l}\text { Estabelecer as causas de } \\
\text { Evasão entre alunos } \\
\text { matriculados em um curso } \\
\text { de especialização }\end{array}$ & $\begin{array}{l}228 \text { alunos evadidos } \\
\text { do curso de } \\
\text { especialização em } \\
\text { Esporte Escolar, } \\
\text { ofertado pelo } \\
\text { Programa Segundo } \\
\text { Tempo do Ministério } \\
\text { do Esporte em } \\
\text { parceria com o } \\
\text { Centro de Educação a } \\
\text { Distância (CEAD) da } \\
\text { Universidade de } \\
\text { Brasília }\end{array}$ & $\begin{array}{l}\text { - Instrumento } \\
\text { "Comportamentos e } \\
\text { Atitudes do Aluno em } \\
\text { Relação a Cursos a } \\
\text { Distância", } \\
\text { desenvolvido por } \\
\text { Walter (2006) }\end{array}$ & $\begin{array}{l}\text { Análises } \\
\text { Descritivas; } \\
\text { Análises } \\
\text { inferenciais; } \\
\text { Análises de } \\
\text { conteúdo; }\end{array}$ & $\begin{array}{l}\text { - Identificação de cinco categorias de fatores } \\
\text { relacionados à desistência acadêmica: } \\
\text { 1. fatores situacionais; } \\
\text { 2. falta de apoio acadêmico; } \\
\text { 3. problemas com a tecnologia; } \\
\text { 4. sobrecarga de trabalho; } \\
\text { 5. falta de apoio administrativo (dificuldades } \\
\text { na distribuição e recebimento de materiais } \\
\text { didáticos, prazos insuficientes para o envio de } \\
\text { atividades, acumulação de tarefas, etc.); }\end{array}$ \\
\hline Holder (2007) & & $\begin{array}{lrr}\text { Avaliar preditores } & \text { de } \\
\text { persistência } & \text { em } & \text { ações } \\
\text { educacionais } & & \text { não } \\
\text { presenciais } & & \end{array}$ & $\begin{array}{l}259 \text { estudantes } \\
\text { inscritos (evadidos ou } \\
\text { não) em programas } \\
\text { de ensino virtual nos } \\
\text { mais diferentes níveis } \\
\text { (associados, } \\
\text { bacharéis ou } \\
\text { mestrado) e áreas de } \\
\text { formação }\end{array}$ & $\begin{array}{l}\text { - Instrumento de medida } \\
\text { (composto por } 60 \text { itens) } \\
\text { versando sobre } \\
\text { variáveis relacionadas à } \\
\text { motivação, ao ambiente } \\
\text { e ao próprio aluno }\end{array}$ & $\begin{array}{l}\begin{array}{l}\text { Análises } \\
\text { descritivas; }\end{array} \\
\text { Análises } \\
\text { multivariadas; } \\
\text { Análises de } \\
\text { confiabilidade; }\end{array}$ & $\begin{array}{l}\text { Estudantes não evadidos (N=209) obtiveram as } \\
\text { taxas mais altas nas medidas ambientais } \\
\text { denominadas Suporte Emocional; Autoeficácia; e } \\
\text { Tempo e Gerenciamento dos Estudos do } \\
\text { instrumento utilizado. }\end{array}$ \\
\hline
\end{tabular}


Tabela 2. Resultados de pesquisas nacionais e internacionais sobre "Evasão e Persistência em EAD” (continuação).

\begin{tabular}{|c|c|c|c|c|c|}
\hline Autores & Objetivo & Amostra/Contexto & $\begin{array}{l}\text { Procedimentos de } \\
\text { coleta de dados }\end{array}$ & $\begin{array}{c}\text { Procedimentos } \\
\text { de análise de } \\
\text { dados }\end{array}$ & Resultados \\
\hline Walter (2008) & $\begin{array}{l}\text { Analisar relações entre } \\
\text { variáveis relativas às } \\
\text { características da clientela, } \\
\text { características do curso e } \\
\text { comportamentos do } \\
\text { estudante em relação à } \\
\text { EAD com a variável } \\
\text { critério Evasão }\end{array}$ & $\begin{array}{l}1.494 \text { estudantes - } \\
615 \text { evadidos e } 879 \\
\text { concluintes }- \text { de dois } \\
\text { cursos dois cursos } \\
\text { oferecidos pelo } \\
\text { Centro de Educação } \\
\text { Tecnológica MSD }\end{array}$ & $\begin{array}{l}\text { - Escalas referentes à } \\
\text { idade, gênero, } \\
\text { participações anteriores } \\
\text { em cursos não } \\
\text { presenciais, pagamento } \\
\text { do curso, valor } \\
\text { instrumental do } \\
\text { treinamento, } \\
\text { modalidade cursada } \\
\text { (híbrida ou totalmente } \\
\text { a distância) e atitudes } \\
\text { do aluno face à EAD }\end{array}$ & $\begin{array}{l}\text { Análises dos } \\
\text { fatores } \\
\text { principais e de } \\
\text { confiabilidade; } \\
\text { Análises de } \\
\text { regressão } \\
\text { logística; }\end{array}$ & $\begin{array}{l}\text { - Estudantes com experiência prévia com a } \\
\text { modalidade de EAD evadiram-se em menor } \\
\text { frequência dos cursos; } \\
\text { - Alunos que experimentaram o ensino virtual pela } \\
\text { primeira demonstram ser menos autônomos, } \\
\text { menos aptos a administrar o tempo de estudo, } \\
\text { menos confortáveis e confiantes do que } \\
\text { aprendizes que conservavam algum contato } \\
\text { anterior com e-learning; }\end{array}$ \\
\hline Sales (2009) & $\begin{array}{l}\text { Propor e testar um modelo } \\
\text { estatístico de predição da } \\
\text { situação de alunos } \\
\text { (concluintes/evadidos) de } \\
\text { treinamentos a distância, } \\
\text { mediados pela Web. }\end{array}$ & $\begin{array}{l}626 \text { estudantes } \\
\text { egressos de } \\
\text { treinamentos } \\
\text { fornecidos pela } \\
\text { Embrapa aos seus } \\
\text { empregados. }\end{array}$ & $\begin{array}{l}\text { - Questionário } \\
\text { "Características do } \\
\text { Curso a Distância” } \\
\text { - Questionário } \\
\text { "Características do } \\
\text { Aluno" } \\
\text { - Questionário } \\
\text { "Características do } \\
\text { Contexto do Aluno" }\end{array}$ & 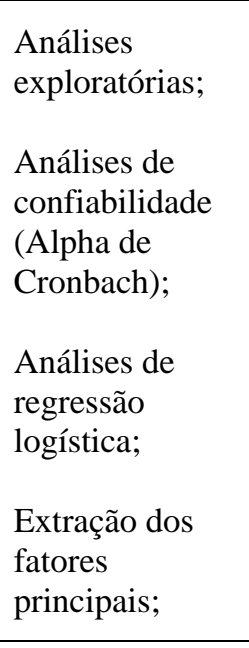 & $\begin{array}{l}\text { - Autoavaliações favoráveis em relação às variáveis } \\
\text { disciplina/interesse pelo curso e reações ao } \\
\text { desempenho do tutor apontam para chances mais } \\
\text { elevadas de conclusão dos treinamentos; }\end{array}$ \\
\hline
\end{tabular}


Tabela 2. Resultados de pesquisas nacionais e internacionais sobre "Evasão e Persistência em EAD” (continuação).

\begin{tabular}{|c|c|c|c|c|c|}
\hline Autores & Objetivo & Amostra/Contexto & $\begin{array}{l}\text { Procedimentos de } \\
\text { coleta de dados }\end{array}$ & $\begin{array}{c}\text { Procedimentos } \\
\text { de análise de } \\
\text { dados }\end{array}$ & Resultados \\
\hline $\begin{array}{l}\text { Pacheco, Rissi, } \\
\text { Nakayama, Silveira e } \\
\text { Spanhol (2010) }\end{array}$ & $\begin{array}{l}\text { Investigar a desistência } \\
\text { estudantil nos Estados } \\
\text { gerenciados pela } \\
\text { Universidade Federal de } \\
\text { Santa Catarina (UFSC) }\end{array}$ & $\begin{array}{l}\text { Aproximadamente } 15 \\
\text { mil indivíduos } \\
\text { envolvidos } \\
\text { (estudantes, } \\
\text { orientadores, tutores) } \\
\text { no Projeto Aluno } \\
\text { Integrado, âmbito da } \\
\text { UFSC }\end{array}$ & $\begin{array}{l}\text { - Análises documentais } \\
\text { (relatórios, banco de } \\
\text { dados do curso, e-mails } \\
\text { emitidos e fóruns) } \\
\text { - Entrevistas }\end{array}$ & $\begin{array}{l}\text { Análises de } \\
\text { conteúdo; } \\
\text { Análises } \\
\text { descritivas; }\end{array}$ & $\begin{array}{l}\text { Entre os fatores responsáveis pela ocorrência de } \\
\text { Evasão destacam-se: } \\
\text { (a) falhas no planejamento do curso; } \\
\text { (b) problemas de navegabilidade do AVA. } \\
\text { (c) falta de suporte acadêmico; } \\
\text { (d) informações equivocadas acerca da modalidade } \\
\text { EAD; } \\
\text { (e) desmotivação do estudante; } \\
\text { (f) dificuldades do aluno em gerenciar o tempo de } \\
\text { estudo; }\end{array}$ \\
\hline Varanda et al. (2010) & $\begin{array}{l}\text { Avaliar o papel } \\
\text { desempenhado pelas } \\
\text { interações firmadas entre } \\
\text { estudante-professor- } \\
\text { colegas e pela } \\
\text { interatividade do ambiente } \\
\text { de estudo nos processos de } \\
\text { aprendizagem }\end{array}$ & $\begin{array}{l}1.892 \text { inscritos no } \\
\text { curso Iniciando um } \\
\text { Pequeno Grande } \\
\text { Negócio (IPGN) } \\
\text { ofertado via internet } \\
\text { pelo SEBRAE }\end{array}$ & $\begin{array}{l}\text { - Escala de "Reações à } \\
\text { Interface Gráfica do } \\
\text { Curso" (15 itens) }\end{array}$ & $\begin{array}{l}\text { Análises } \\
\text { descritivas; } \\
\text { Análise fatorial } \\
\text { exploratória; }\end{array}$ & $\begin{array}{l}\text { Diferenças quanto às características de uso da } \\
\text { interface gráfica entre a amostra considerada e a } \\
\text { população total de estudantes do IPGN são } \\
\text { insípidas. }\end{array}$ \\
\hline $\begin{array}{l}\text { Iglesias e Salgado } \\
(2012)\end{array}$ & $\begin{array}{l}\text { Comparar a efetividade de } \\
\text { duas distintas modalidades } \\
\text { de ensino: treinamento em } \\
\text { sala de aula e treinamento } \\
\text { por videoconferência }\end{array}$ & $\begin{array}{l}561 \text { indivíduos } \\
\text { desempregados } \\
\text { matriculados em } \\
\text { cursos de } \\
\text { empreendedorismo } \\
\text { ofertados pelo } \\
\text { Instituto Gallego para } \\
\text { la Promoción } \\
\text { Económica of the } \\
\text { Xunta de Galicia }\end{array}$ & $\begin{array}{l}\text { - Onze escalas do tipo } \\
\text { Likert que } \\
\text { consideravam aspectos } \\
\text { do treinamento }\end{array}$ & $\begin{array}{l}\text { Análises } \\
\text { descritivas; } \\
\text { Análises de } \\
\text { confiabilidade; }\end{array}$ & $\begin{array}{l}\text { - Os resultados encontrados indicam que as } \\
\text { modalidades consideradas apresentaram elevados } \\
\text { índices de efetividade, caracterizando ambas } \\
\text { como valiosas e válidas opções para programas } \\
\text { instrucionais; } \\
\text { - Em circunstâncias nas quais os conteúdos } \\
\text { didáticos são os mesmos, os participantes não } \\
\text { identificam diferenças se eles são transmitidos } \\
\text { face a face ou por meio de videoconferência; } \\
\text { - Em situações de aprendizagem a distância, o } \\
\text { elemento "tutor" pode desempenhar papel chave } \\
\text { na efetividade de programas de tal natureza; }\end{array}$ \\
\hline
\end{tabular}

Fonte: Umekawa (2014). 
Umekawa (2014) verificou uma produção limitada de estudos ocupados com a investigação sistemática da efetividade de ações educacionais a distância. Dessa forma, reconheceu-se a urgente necessidade de refinamento da modalidade no que tange ao desenvolvimento dos tutores, à adaptação dos cursos ao ambiente de estudo dos discentes, ao emprego adequado das novas ferramentas disponíveis, aos Estilos de Aprendizagem e hábitos de estudo do aprendiz, elementos estes que possivelmente se encontram relacionados aos elevados índices de Evasão registrados e que dificultam os retornos aos altos investimentos na implementação dessa modalidade de ensino.

Nota-se uma grande lacuna e uma área muito fértil para investigação no que se refere à Evasão em ações educacionais ofertadas à distância. Apesar de haver pesquisas importantes destacando a importância do perfil do aluno, do ambiente de estudo e do próprio curso como variáveis influentes nesse processo, o número de investigações ainda não é suficiente. Até mesmo dentre as pesquisas realizadas, nota-se uma preocupação referente aos instrumentos empregados para mensuração e identificação de elementos preditores da Evasão em $e$ learning. Além de serem necessárias pesquisas voltadas para uma melhor adaptação e validação desses instrumentos, têm-se a necessidade de construção de novos instrumentos para medir outros fatores até então não investigados de forma focal.

Alguns autores já falam de fatores relacionados ao perfil do aluno. Shin e Kim (1999) destacam seus fatores exógenos (externos) e endógenos (internos) que influenciam no fenômeno da Evasão. Nesse caso, as Estratégias de Aprendizagem, os Estilos de Aprendizagem, o perfil sociodemográfico e uso de ferramentas eletrônicas, variáveis desse estudo, seriam considerados fatores endógenos. Corroborando esses achados, o estudo de Xenos et al. (2002) relaciona a Evasão com o domínio de recursos tecnológicos, bem como o perfil do aluno (nesse caso, idade e gênero). Da mesma forma, Abbad, Carvalho e Zerbini (2006) demonstram que os alunos que menos participaram das interações no ambiente virtual são os que mais evadiram. Tal evasão pode estar relacionada com o pouco domínio das TICs. Wang et al. (2003) afirmam que a incompatibilidade dos Estilos de Aprendizagem com o desenho do curso pode ser uma causa da Evasão em EAD.

Além das causas apontadas acima, referentes às características pessoais do aluno, os estudos encontrados apontam como causa da Evasão a falta de tempo do aluno. É importante relembrar, que segundo o Abbad (2007), o aluno de EAD geralmente é ativo profissionalmente, restando pouco tempo para se dedicar aos estudos. O professor e/ou tutor também recebe destaque nos achados da literatura. A Evasão aparece relacionada com o 
relacionamento com o professor e/ou tutor e os alunos. Destacam-se também problemas em sua atuação, além da dificuldade de entrar em contato.

Silva e Tomaz (2006) destacam como principais causas da Evasão: (a) variáveis relacionadas ao desenho instrucional do curso (ex, dificuldades de encontrar informações no AVA, proposição de exercícios pouco didáticos); (b) experiência e habilidade limitada com a estrutura tecnológica do curso; (c) o estudo solitário; (d) desmotivação; e (e) escassez de tempo. Ou seja, mais uma vez os fatores internos ao aluno ganham destaque.

Portanto, os objetivos da presente pesquisa visam suprir algumas das lacunas apresentadas no levantamento feito por Umekawa (2014): uma investigação mais aprofundada referente aos Estilos de Aprendizagem em ações educacionais ofertadas a distância, além de verificar sua relação com a Evasão nesse contexto.

A próxima seção apresenta variável Estratégias de Aprendizagem, seus conceitos e alguns estudos relacionados.

\subsection{Estratégias de Aprendizagem}

Estratégias de Aprendizagem são procedimentos (habilidades cognitivas e comportamentais) utilizados pelos indivíduos durante as atividades de aprendizagem de modo a garantir o sucesso de todas as etapas do processo. São procedimentos focados apenas em atividades de aprendizagem. As estratégias podem ser modificadas por treinamento com o intuito de aumentar a efetividade da aprendizagem em uma atividade ou ambiente específico (Warr \& Allan, 1998; Warr \& Downing, 2000; Zerbini \& Abbad, 2008).

Estratégias de Aprendizagem podem ser entendidas como sendo ações sistematizadas pelos aprendizes intentando cumprir determinadas tarefas e alcançar metas estabelecidas. Oferecendo subsídios ao processamento de novos conhecimentos, as Estratégias de Aprendizagem encontram-se positivamente relacionadas com a aprendizagem exitosa, segundo trabalhos da psicologia organizacional ou do campo educacional que focalizam as características próprias do estudante (Oliveira, Boruchovitch \& Santos, 2009; Souza, 2010; Warr \& Downing, 2000). De acordo com Sonnentag, Niesse e Ohly (2004), em âmbito organizacional as chamadas Estratégias de Aprendizagem corresponderiam às ações e medidas cognitivas efetuadas pelo sujeito visando a compreensão de determinado objeto.

Em classificação proposta por Warr e Allan (1998) duas categorias de Estratégias de Aprendizagem são destacadas em contextos organizacionais e de trabalho: primárias (cognitivas e comportamentais) e autorregulatórias. As primeiras interferem sobre os 
processos de escolha, processamento, retenção e recuperação de informações, sendo usadas, portanto, na ocasião em que se dá o contato do aprendiz com os conteúdos a serem transmitidos. Por outro lado, as autorregulatórias dizem respeito à motivação da pessoa para aprender, a autogestão de esforços, o automonitoramento do progresso durante a aprendizagem, e o controle da ansiedade frente a determinadas situações que estariam dissipando a atenção do aprendiz. Essa segunda categoria afeta de maneira indireta o momento de interação do aprendiz com o objeto de conhecimento, afetando a forma como o mesmo sustém a motivação, gerenciamento, monitoramento do seu progresso e da ansiedade (Zerbini \& Abbad, 2008).

Durante o processo de aquisição de conhecimentos, aprendizes devem ser orientados, auxiliados e incentivados a usar as estratégias mais adequadas e saber identificar as estratégias de (in)sucesso, reconsiderando e aprimorando os passos a serem tomados. Há a necessidade de envolver os aprendizes em processos autorregulatórios durante o treinamento, para incentivá-los a refletir se estão aprendendo o que deveriam aprender e a ajustar a aquisição dos novos aprendizados, quando necessário (Salas et al., 2012), uma vez que as Estratégias de Aprendizagem vêm sendo comprovadamente e positivamente relacionadas a bons resultados e sucesso acadêmico em ambientes de aprendizagem online (Costa \& Boruchovitch, 2009; Johnson, Gueutal \& Falbe, 2009; Martins, 2012; Oliveira et al., 2009; Warr \& Bunce, 1995; Warr \& Downing, 2000), especialmente aquelas que promovem o monitoramento da compreensão e o controle da motivação, ansiedade e atenção no momento de estudo, ou seja, as autorregulatórias

De acordo com Kearley e Moore (2005), as iniciativas de EAD implicam em condutas e formas de agir por parte dos discentes que se diferenciam daquelas já conhecidas e desempenham papel crucial para o êxito de tais ações. Por conta disso, esses ambientes exigem e favorecem a elaboração de competências indispensáveis a um processo de aprendizagem mais independente e maleável, levando em conta tempo, espaço e ritmo daquele que aprende, por meio de uma série de expedientes didáticos ajustados a variadas mídias e recursos tecnológicos (Bjork, Dunlosky \& Kornell, 2013; Carswell \& Venkatesh, 2002; Castro \& Ferreira, 2006). As modalidades de ensino à distância, por serem mais individualizadas e independentes, possibilitam que os aprendizes se envolvam mais com a autoaprendizagem, e todas essas transformações incidirão sobre os processos de aquisição do conhecimento e as formas de avaliá-la (Umekawa, 2014). 
As características individuais podem ter maior influência nos efeitos de treinamentos a distância do que nos presenciais, por se tratar de uma aprendizagem que parece depender mais do esforço do próprio indivíduo (autogerenciamento da aprendizagem) do que dos recursos instrucionais (Zerbini, 2007). Além das características mais estudadas tais como gênero, idade, motivação, ansiedade e autoeficácia, devem-se investigar variáveis cognitivocomportamentais, tais como as Estratégias de Aprendizagem utilizadas pelos alunos durante ações educacionais de natureza diferentes (Meneses et al., 2006; Warr \& Allan, 1998; Warr \& Downing, 2000). O estudo das Estratégias de Aprendizagem usadas pelos aprendizes pode auxiliar no planejamento instrucional de cursos a distância, podendo os resultados de pesquisa ser utilizados no delineamento e aperfeiçoamento dos mesmos (Santos et al., 2004; Zerbini, 2007). Ou ainda, por serem passíveis de serem aprendidas e modificadas, o ensino e o aperfeiçoamento de tais estratégias implicariam, não necessariamente, na mudança dos procedimentos instrucionais, mas afetariam a maneira que os aprendizes procedem ao aprender.

A análise e compreensão acerca das Estratégias de Aprendizagem podem ser de grande valia para aperfeiçoar o planejamento instrucional de ações a distância, uma vez que favorecem o reconhecimento dos processos individuais de aprendizagem utilizados e dos procedimentos instrucionais mais adequados a cada agente envolvido (Santos et al., 2004; Zerbini, 2007; Zerbini \& Abbad, 2010).

As Estratégias de Aprendizagem em ambientes virtuais são discutidas por Badia e Monereo (2010) como competências e habilidades imprescindíveis para sobreviver na sociedade-rede. É destacado que os ambientes instrucionais baseados em computadores são úteis para o ensino de estratégias, pois possuem características singulares como: a) necessidade de planejar, especificar e revisar as próprias decisões para o alcance de resultados esperados; b) as TICs promovem uma interação dinâmica entre os objetos de conhecimento e os sujeitos que compartilham sua aquisição; c) são aumentadas as possibilidades de aprender novas formas de gestão do conhecimento graças à versatilidade dos formatos de representação da informação e à facilidade para criar e modificar redes de conhecimento. Consequentemente, são contextos os quais promovem e requerem o desenvolvimento de habilidades para uma aprendizagem mais independente e flexível, considerando tempo, espaço e ritmo do aprendiz, através de um conjunto de recursos didáticos adaptados a tecnologias e múltiplas mídias (Carswell \& Venkatesh, 2002; Castro \& Ferreira, 2006; Cheung, 2000). 
Para Martins (2012), as principais definições de Estratégias de Aprendizagem são as elaboradas por Warr \& Allan (1998) e revistas por Zerbini (2007). Abaixo a Tabela 3 apresenta essas definições.

Tabela 3. Classificação e definições das Estratégias de Aprendizagem.

Estratégias - Repetição: abrange procedimentos de repetição mental da informação na cognitivas

forma em que foi apresentada

- Organização: consiste na identificação de ideias centrais do material e criação de esquemas mentais que agrupam e relacionam elementos a serem aprendidos

- Elaboração: avalia ou reflete sobre implicações e conexões possíveis entre o material aprendido e o conhecimento já existente

Estratégias comportamentais
- Busca de ajuda interpessoal: obtenção de auxílio de outras pessoas, como pares e professores, para tirar dúvidas sobre o material (representa um comportamento proativo do indivíduo de solicitar ajuda ao invés de utilizar apenas as informações do próprio procedimento instrucional)

- Busca de ajuda no material didático: obtenção de informações em documentos escritos, manuais de instruções, programas de computador e outras fontes que não envolvam contato social

- Aplicação prática: aprimoramento do conhecimento por meio de aplicação prática do que foi aprendido

Estratégias autorregulatórias
- Controle da emoção: controle da ansiedade e prevenção de dispersões de concentração, causadas por sentimentos de ansiedade.

- Controle da motivação: controlar a motivação e a atenção, apesar de existência de um interesse limitado na tarefa a ser aprendida.

- Monitoramento da compreensão: a avaliação do processo de aquisição de aprendizagem e modificação do comportamento do indivíduo quando necessário

Fonte: Warr \& Allan (1998); Zerbini (2007); Martins (2012).

O breve apanhado feito por Umekawa (2014) sobre obras dedicadas à variável Estratégias de Aprendizagem revela a preocupação em compreender as habilidades empregadas pelos alunos a fim de estudarem e aprenderem em diversificadas situações de ensino (Costa \& Boruchovitch, 2004; Gomes \& Boruchovitch, 2005; Joly, Cantalice \& Vendramini, 2004; Machado, 2005; Oliveira et al, 2011). Entre as pesquisas levantadas foi observada preocupação no que tange ao fomento das Estratégias de Aprendizagem metacognitivas e ligadas à gestão do tempo - tidas como muito relevantes para os processos de autorregulação do conhecimento e do tempo, tão presentes nos AVAs. Por fim, tal como apregoa Beluce e Oliveira (2012), o campo das produções científicas voltado ao estudo das Estratégias de Aprendizagem em contextos de ensino online vem testemunhando avanços satisfatórios, todavia é necessário reconhecer que tais progressos não se fazem suficientes tendo em vista a seriedade do tema à educação, presencial e a distância. Com isso, faz-se indispensável o desenvolvimento de pesquisas que não somente se detenham nos aspectos já considerados, mas lancem mão de novas contribuições ao estudo desta temática. 
Para caracterizar as Estratégias de Aprendizagem, foi analisada a revisão de literatura produzida por Martins (2015). A autora realizou um levantamento bibliográfico, que dentre outros objetivos, pretendeu apresentar instrumentos nacionais e internacionais construídos com o objetivo de mensurar Estratégias de Aprendizagem em contextos educacionais, bem como resultados de pesquisa que objetivaram analisar o relacionamento entre variáveis. Os estudos levantados na revisão de literatura mostram um esforço da área de pesquisa na elaboração de instrumentos válidos e padronizados destinados a medir Estratégias de Aprendizagem em diferentes níveis educacionais. Na Tabela 4, seguem os principais achados da pesquisa de Martins (2015). 
Tabela 4. Pesquisas sobre Estratégias de Aprendizagem

\begin{tabular}{|c|c|c|c|c|c|}
\hline Autores & Objetivo & Amostra/Contexto & $\begin{array}{c}\text { Procedimentos de } \\
\text { coleta de dados }\end{array}$ & $\begin{array}{c}\text { Procedimentos de } \\
\text { análise de dados }\end{array}$ & Resultados \\
\hline $\begin{array}{l}\text { Warr e } \\
\text { Downing } \\
(2000)\end{array}$ & $\begin{array}{l}\text { Validar uma escala de } \\
\text { Estratégias de Aprendizagem e } \\
\text { investigar a relação entre } \\
\text { Estratégias de Aprendizagem, } \\
\text { ansiedade para aprender e } \\
\text { aquisição de conhecimento }\end{array}$ & $\begin{array}{l}152 \text { participantes de } \\
\text { um curso de mecânica } \\
\text { básica }\end{array}$ & $\begin{array}{l}\text { Aplicação de } \\
\text { questionários }\end{array}$ & $\begin{array}{l}\text { Análise fatorial } \\
\text { exploratória }\end{array}$ & $\begin{array}{l}\text { Apenas busca por ajuda interpessoal } \\
\text { e monitoramento da compreensão } \\
\text { não foram positivamente } \\
\text { relacionadas a mudanças no } \\
\text { conhecimento; } \\
\text { Estratégias de ensaio, busca de } \\
\text { ajuda interpessoal e de material } \\
\text { escrito, controle emocional e } \\
\text { motivacional são mais utilizadas } \\
\text { pelos participantes com alta } \\
\text { ansiedade em relação a tarefa de } \\
\text { aprendizagem; } \\
\text { Participantes com altos níveis de } \\
\text { motivação anterior a aprendizagem } \\
\text { usam mais reflexão ativa, controle } \\
\text { emocional e monitoramento da } \\
\text { compreensão; } \\
\text { Participantes com trabalhos } \\
\text { anteriores relevantes usam menos } \\
\text { busca de ajuda interpessoal e de } \\
\text { material escrito e controle } \\
\text { emocional; } \\
\text { Participantes mais velhos usam } \\
\text { mais a estratégia de ensaio. }\end{array}$ \\
\hline
\end{tabular}


Tabela 4. Pesquisas sobre Estratégias de Aprendizagem (continuação).

\begin{tabular}{|c|c|c|c|c|c|}
\hline Autores & Objetivo & Amostra/Contexto & $\begin{array}{c}\text { Procedimentos de } \\
\text { coleta de dados }\end{array}$ & $\begin{array}{c}\text { Procedimentos de } \\
\text { análise de dados }\end{array}$ & Resultados \\
\hline $\begin{array}{l}\text { Holman, } \\
\text { Epitropaki e } \\
\text { Fernie }(2001)\end{array}$ & $\begin{array}{l}\text { Validar uma escala de } \\
\text { Estratégias de Aprendizagem, } \\
\text { provinda de ambiente } \\
\text { educacional, em um contexto } \\
\text { organizacional }\end{array}$ & $\begin{array}{l}628 \text { agentes de call } \\
\text { center de um banco } \\
\text { (Reino Unido) }\end{array}$ & $\begin{array}{l}\text { Aplicação de } \\
\text { questionários }\end{array}$ & $\begin{array}{l}\text { Análises fatoriais } \\
\text { exploratórias e } \\
\text { confirmatórias }\end{array}$ & 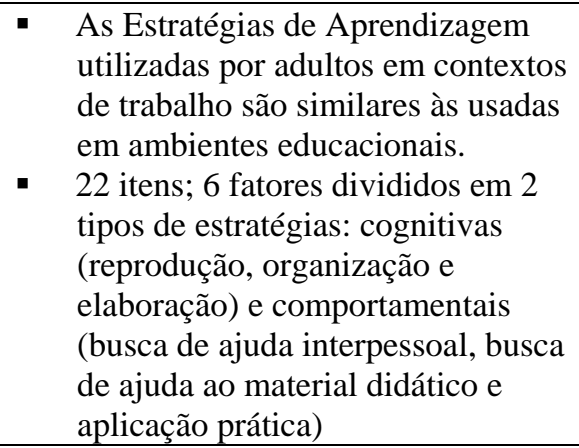 \\
\hline $\begin{array}{l}\text { Zerbini e } \\
\text { Abbad (2005) }\end{array}$ & $\begin{array}{l}\text { Relacionar o uso de } \\
\text { Estratégias de Aprendizagem } \\
\text { às reações aos procedimentos } \\
\text { instrucionais de um curso via } \\
\text { internet e reações ao tutor e } \\
\text { impacto do treinamento no } \\
\text { trabalho }\end{array}$ & $\begin{array}{l}188 \text { e } 354 \text { participantes } \\
\text { do curso a distância } \\
\text { IPGN (SEBRAE) }\end{array}$ & $\begin{array}{l}\text { Aplicação de } \\
\text { questionários online }\end{array}$ & $\begin{array}{l}\text { Análise fatorial } \\
\text { exploratória } \\
\text { Análise de regressão } \\
\text { múltipla }\end{array}$ & $\begin{array}{l}\text { - Apenas as estratégias de elaboração } \\
\text { e aplicação prática explicaram o } \\
\text { impacto do treinamento no trabalho. }\end{array}$ \\
\hline Pantoja (2004) & $\begin{array}{l}\text { Investigar o relacionamento } \\
\text { entre Estratégias de } \\
\text { Aprendizagem, características } \\
\text { da organização e percepções } \\
\text { de suporte à aprendizagem } \\
\text { contínua }\end{array}$ & $\begin{array}{l}900 \text { trabalhadores de } \\
16 \text { categorias distintas } \\
\text { atuantes em diferentes } \\
\text { segmentos } \\
\text { organizacionais }\end{array}$ & $\begin{array}{l}\text { Aplicação de } \\
\text { questionários }\end{array}$ & $\begin{array}{l}\text { Teste de } 5 \text { modelos } \\
\text { multiníveis para } \\
\text { verificação do efeito } \\
\text { específico de } \\
\text { variáveis preditoras } \\
\text { nas Estratégias de } \\
\text { Aprendizagem no } \\
\text { local de trabalho } \\
\text { Análise fatorial } \\
\text { exploratória }\end{array}$ & $\begin{array}{l}\text { Diferentes correlações encontradas } \\
\text { entre as variáveis individuais } \\
\text { (idade, gênero, anos de estudo, } \\
\text { categoria profissional) e a utilização } \\
\text { de Estratégias de Aprendizagem no } \\
\text { local de trabalho; } \\
\text { - Destaque para a estratégia aplicação } \\
\text { prática para a aprendizagem dos } \\
\text { indivíduos nos contextos } \\
\text { organizacionais estudados; } \\
\text { Há diferenças significativas entre as } \\
\text { Estratégias de Aprendizagem } \\
\text { utilizadas no local de trabalho } \\
\text { conforme a categoria profissional. }\end{array}$ \\
\hline
\end{tabular}


Tabela 4. Pesquisas sobre Estratégias de Aprendizagem (continuação).

\begin{tabular}{|c|c|c|c|c|c|}
\hline Autores & Objetivo & Amostra/Contexto & $\begin{array}{c}\text { Procedimentos de } \\
\text { coleta de dados }\end{array}$ & $\begin{array}{c}\text { Procedimentos de } \\
\text { análise de dados }\end{array}$ & Resultados \\
\hline $\begin{array}{l}\text { Pantoja e } \\
\text { Borges- } \\
\text { Andrade (2009) }\end{array}$ & $\begin{array}{l}\text { Mapear Estratégias de } \\
\text { Aprendizagem no trabalho } \\
\text { com o objetivo de classificar } \\
\text { dezesseis ocupações } \\
\text { profissionais, em quatro } \\
\text { categorias de postos de } \\
\text { trabalho, bem como descrever } \\
\text { e comparar as estratégias } \\
\text { utilizadas pelos indivíduos } \\
\text { para aprenderem, em seu dia- } \\
\text { a-dia no trabalho, nessas } \\
\text { diferentes categorias } \\
\text { profissionais }\end{array}$ & $\begin{array}{l}12 \text { coordenadores de } \\
\text { RH e } 55 \text { representantes } \\
\text { das dezesseis } \\
\text { ocupações profissionais } \\
\text { estudadas }\end{array}$ & $\begin{array}{l}\text { Entrevistas } \\
\text { semiestruturadas } \\
\text { baseadas na técnica } \\
\text { de incidentes críticos }\end{array}$ & Análise de conteúdo & $\begin{array}{l}\text { As estratégias aplicação prática e } \\
\text { busca de ajuda interpessoal } \\
\text { exerceram papel primordial nos } \\
\text { processos de aquisição, retenção e } \\
\text { transferência de novas } \\
\text { competências em âmbito laboral; } \\
\text { Diferentes configurações de uso de } \\
\text { Estratégias de Aprendizagem } \\
\text { estiveram associadas às categorias } \\
\text { profissionais estudadas. }\end{array}$ \\
\hline $\begin{array}{l}\text { Zerbini e } \\
\text { Abbad (2008, } \\
\text { 2010) }\end{array}$ & $\begin{array}{l}\text { Identificar variáveis } \\
\text { explicativas da aplicação de } \\
\text { habilidades ensinadas aos } \\
\text { participantes de um curso de } \\
\text { qualificação profissional a } \\
\text { distância, via internet }\end{array}$ & $\begin{array}{l}\text { 4.719/470 participantes } \\
\text { do curso a distância } \\
\text { IPGN (SEBRAE) }\end{array}$ & $\begin{array}{l}\text { Aplicação de } \\
\text { questionários online }\end{array}$ & $\begin{array}{l}\text { Análise fatorial } \\
\text { exploratória } \\
\text { Análise de regressão } \\
\text { múltipla }\end{array}$ & $\begin{array}{l}\text { Participantes que utilizaram com } \\
\text { mais frequência as Estratégias de } \\
\text { Aprendizagem elaboração e } \\
\text { monitoramento da compreensão } \\
\text { foram os que relataram maior } \\
\text { ocorrência de impacto do } \\
\text { treinamento no trabalho; } \\
\text { Os participantes que elaboraram o } \\
\text { plano de negócios utilizaram com } \\
\text { mais frequência a estratégia de } \\
\text { aprendizagem busca de ajuda } \\
\text { interpessoal. }\end{array}$ \\
\hline $\begin{array}{l}\text { Abbad, Côrrea } \\
\text { e Meneses } \\
(2010)\end{array}$ & $\begin{array}{l}\text { Analisar as relações entre } \\
\text { Estratégias de Aprendizagem e } \\
\text { satisfação com treinamentos a } \\
\text { distância }\end{array}$ & $\begin{array}{l}216 \text { participantes de } \\
\text { cinco cursos realizados } \\
\text { a distância }\end{array}$ & $\begin{array}{l}\text { Aplicação de } \\
\text { questionários }\end{array}$ & $\begin{array}{l}\text { Análise fatorial } \\
\text { exploratória } \\
\text { Análises de } \\
\text { correlações bivariadas }\end{array}$ & $\begin{array}{l}\text { Padrões de associação entre } \\
\text { determinadas estratégias cognitivas } \\
\text { de aprendizagem e satisfação com o } \\
\text { desempenho da tutoria, com os } \\
\text { procedimentos e os resultados e } \\
\text { com a interface gráfica do curso }\end{array}$ \\
\hline
\end{tabular}


Tabela 4. Pesquisas sobre Estratégias de Aprendizagem (continuação).

\begin{tabular}{|c|c|c|c|c|c|}
\hline Autores & Objetivo & Amostra/Contexto & $\begin{array}{l}\text { Procedimentos de } \\
\text { coleta de dados }\end{array}$ & $\begin{array}{c}\text { Procedimentos de } \\
\text { análise de dados }\end{array}$ & Resultados \\
\hline $\begin{array}{l}\text { Testa e Luciano } \\
\text { (2010) }\end{array}$ & $\begin{array}{l}\text { Investigar o papel } \\
\text { desempenhado pelas } \\
\text { Estratégias de Aprendizagem } \\
\text { utilizadas na regulação de } \\
\text { recursos de aprendizagem em } \\
\text { ambientes virtuais de ensino }\end{array}$ & $\begin{array}{l}\text { Participantes: } 28 \\
\text { (entrevistados) e } 104 \\
\text { (questionários) }\end{array}$ & $\begin{array}{l}\text { Entrevistas } \\
\text { semiestruturadas e } \\
\text { abertas; análise de } \\
\text { documentos e de } \\
\text { registros; observação } \\
\text { direta; e pesquisa } \\
\text { survey }\end{array}$ & $\begin{array}{l}\text { Análise de conteúdo } \\
\text { Análise fatorial } \\
\text { exploratória }\end{array}$ & $\begin{array}{l}\text { Participantes que mais } \\
\text { frequentemente estabeleceram } \\
\text { interações com pares e professores, } \\
\text { para tirar dúvidas ou buscar auxílio, } \\
\text { atingiram as mais elevadas médias } \\
\text { nos itens interesse, persistência, } \\
\text { percepção de autoconfiança e } \\
\text { gestão do ambiente social da escala } \\
\text { MSLQ (Motivated Strategies for } \\
\text { Learning Questionnaire); } \\
\text { Correlações significativas entre as } \\
\text { elevadas taxas de satisfação com o } \\
\text { estudo e desempenho acadêmico e a } \\
\text { utilização de estratégias para gestão } \\
\text { do tempo e esforço. } \\
\text { Implicações práticas: estabelecer } \\
\text { prazos curtos e frequentes para a } \\
\text { conclusão das tarefas; fixar nos } \\
\text { critérios avaliativos elementos que } \\
\text { tratem do gerenciamento de tempo; } \\
\text { investir em interações viabilizadas } \\
\text { pelo recurso do chat ou por meio de } \\
\text { videoconferências; sugerir } \\
\text { atividades não formais nas quais os } \\
\text { estudantes partilhem preferências, } \\
\text { opiniões, etc. }\end{array}$ \\
\hline $\begin{array}{l}\text { Brandão \& } \\
\text { Borges- } \\
\text { Andrade (2011) }\end{array}$ & $\begin{array}{l}\text { Desenvolver uma escala de } \\
\text { Estratégias de Aprendizagem } \\
\text { no trabalho e verificar a } \\
\text { frequência com que estas são } \\
\text { utilizadas por gestores de um } \\
\text { banco público }\end{array}$ & $\begin{array}{l}881 \text { gestores de } \\
\text { agências bancárias } \\
\text { brasileiras }\end{array}$ & $\begin{array}{l}\text { Levantamento } \\
\text { documental, } \\
\text { entrevistas e } \\
\text { questionários }\end{array}$ & $\begin{array}{l}\text { Análises descritivas e } \\
\text { fatoriais exploratórias }\end{array}$ & $\begin{array}{l}\text { As Estratégias de Aprendizagem } \\
\text { busca de ajuda interpessoal e } \\
\text { reflexão ativa foram as mais } \\
\text { utilizadas pela amostra. }\end{array}$ \\
\hline
\end{tabular}

Fonte: Martins (2015). 
Os achados apontam para a relação entre Estratégias de Aprendizagem e diversas outras variáveis, tais como motivação para estudar, aquisição e retenção de conteúdo, autoconfiança e até variáveis individuais (idade, gênero, anos de estudo). Nota-se que as Estratégias de Aprendizagem influenciam em muitos aspectos no processo de ensino.

Warr e Downing (2000) apontam que a estratégia de ajuda interpessoal não possui relação com mudanças no conhecimento, mas é muito utilizada em estudantes com muita ansiedade para tarefas de aprendizagem. Ainda relacionado a isso, Testa e Luciano (2010) afirmam que quanto maior a interação do aluno com professores/tutores ou com outros alunos, seja para dúvida ou para auxílio, maior a sua autoconfiança para aprender.

Mais uma vez ganha destaque na literatura a relação entre o conhecimento adquirido e sua aplicação prática. Holman, Epitropaki e Fernie (2001) destacam que as Estratégias de Aprendizagem utilizadas no trabalho são as mesmas utilizadas nos ambientes educacionais. Já Pantoja e Borges-Andrade (2009) dão à Estratégia de Aplicação Prática um papel primordial nos processos de aquisição, retenção e transferência de novas competências. Ou seja, nota-se a importância da aplicação prática do conteúdo das aulas. $\mathrm{O}$ aluno da EAD, por trabalhar na maioria das vezes, relaciona esses dois ambientes com muita facilidade.

Por fim, corroborando com a revisão de literatura sobre a Evasão em EAD, Testa e Luciano (2010) demonstram em seu estudo que quanto maior a gestão do tempo do aluno, maior sua satisfação com o estudo e seu desempenho acadêmico. A falta de tempo foi apontada como um dos principais fatores relacionados à evasão em cursos EAD (Umekawa, 2014).

Porém, nota-se a ausência de estudos relacionando Estratégias de Aprendizagem com a Evasão escolar, fato que já foi discutido por Umekawa (2014) como fundamental investigação. Em seu trabalho, a autora discorre sobre o assunto, afirmando que a depender dos desarranjos ou variáveis consideradas negativas a sua permanência em cursos a distância, o indivíduo pode fazer uso de distintas Estratégias de Aprendizagem a fim de superar tais elementos dificultadores. Assim como revela a literatura especializada, o emprego de Estratégias de Aprendizagem facilita o processo de ensino, uma vez que propicia meios à aquisição, recuperação e uso dos conteúdos de aprendizagem. Com todos estes indicativos em mente, é crível que a observância quanto aos padrões de uso e frequência das Estratégias de Aprendizagem por parte dos alunos viabilize o reconhecimento daqueles fatores que exercerão forte influência sobre a decisão discente de abandonar ou não a ação instrucional. 
Levando em consideração à área em que essa pesquisa está inserida, nesse trabalho será utilizada a seguinte definição de Estratégias de Aprendizagem: "são procedimentos (habilidades cognitivas e comportamentais) utilizados pelos indivíduos durante as atividades de aprendizagem de modo a garantir o sucesso de todas as etapas do processo. São procedimentos focados apenas em atividades de aprendizagem" (Warr \& Allan, 1998; Warr \& Downing, 2000; Zerbini \& Abbad, 2008).

Após realizada a contextualização da presente pesquisa, o próximo capítulo tratará da principal variável de interesse deste estudo: os Estilos de Aprendizagem. Será exposta a revisão de literatura elaborada acerca dessa variável. 


\section{CAPÍTULO 3. ESTILOS DE APRENDIZAGEM}

\section{Objetivo do capítulo 3}

O presente capítulo tem como objetivo discutir sobre a principal variável de interesse dessa pesquisa: os Estilos de Aprendizagem. Será apresentada a revisão de literatura realizada sobre o tema no contexto de ações educacionais ofertadas a distância.

Para realizar a análise da literatura referente aos Estilos de Aprendizagem, foi realizado um levantamento bibliográfico nas bases de dados consideradas importantes em revisões de TD\&E (Martins, 2012). Assim, buscou-se por resultados de pesquisas em Estilos de Aprendizagem em cursos de ensino superior ofertados à distância.

Para a atualização e sistematização de resultados de pesquisa sobre as variáveis de interesse do presente estudo, foram realizadas revisões bibliográficas em bases de dados eletrônicas, abrangendo o período de 2007 a 2014. Tal período se justifica no sentido de que a primeira produção que embasou o estudo sobre Estilos de Aprendizagem na área de POT no Brasil foi publicada em 2007.

Foram analisadas produções científicas nacionais e internacionais na biblioteca eletrônica da CAPES, nas bases de dados ProQuest e Web of Science, além dos bancos de dissertações e teses da Universidade de São Paulo (USP) e da Universidade de Brasília (UnB). O levantamento bibliográfico visou examinar os avanços na construção e validação de instrumentos nacionais e estrangeiros que se dedicaram a mensurar os Estilos de Aprendizagem em alunos de cursos superiores a distância. Para tal, foram usadas as palavras chaves Estilos de Aprendizagem (Learning Styles), Educação a distância (Distance Education), Ensino Superior (Higher Education) e e-learning.

Para uma maior adequação à pesquisa, foram selecionados artigos das áreas de Psicologia e da Educação. A busca por artigos na área da Educação se justifica por sua significativa produção acerca dos Estilos de Aprendizagem. A revisão da literatura encontrou, conforme a Tabela 5, o total de 1.226 artigos. Dentre eles foram selecionados os artigos das áreas de Psicologia e Educação, resultando em 23 artigos, dos quais 10 estavam disponíveis para download. 
Tabela 5. Controle de busca da revisão bibliográfica de Estilos de Aprendizagem.

\begin{tabular}{|c|c|c|c|}
\hline \multirow{2}{*}{ Palavras-chave } & \multicolumn{3}{|c|}{ Número de artigos } \\
\hline & Encontrados & Selecionados & Lidos \\
\hline \multicolumn{4}{|l|}{ Web of Science } \\
\hline Learning Styles and Distance Learning & 31 & 5 & 1 \\
\hline Learning Styles and e-learning & 270 & 7 & 1 \\
\hline Learning Styles and e-learning and higher education & 76 & 1 & 0 \\
\hline \multicolumn{4}{|l|}{ Pro Quest } \\
\hline Learning Styles and Distance Learning & 382 & 4 & 2 \\
\hline Learning Styles and e-learning & 269 & 2 & 2 \\
\hline Learning Styles and e-learning and higher education & 92 & 1 & 1 \\
\hline \multicolumn{4}{|l|}{ CAPES } \\
\hline Estilos de Aprendizagem e educação a distância & 17 & 0 & 0 \\
\hline Estilos de Aprendizagem e Ensino Superior & 38 & 0 & 0 \\
\hline Estilos de Aprendizagem & 8 & 0 & 0 \\
\hline \multicolumn{4}{|l|}{ UnB } \\
\hline Estilos de Aprendizagem e educação a distância & 0 & 0 & 0 \\
\hline Estilos de Aprendizagem e Ensino Superior & 0 & 0 & 0 \\
\hline Estilos de Aprendizagem & 7 & 2 & 2 \\
\hline \multicolumn{4}{|c|}{ Tabela 1: Controle de busca da revisão bibliográfica de Estilos de Aprendizagem } \\
\hline \multicolumn{4}{|c|}{ USP } \\
\hline Estilos de Aprendizagem e educação a distância & 5 & 0 & 0 \\
\hline Estilos de Aprendizagem e Ensino Superior & 4 & 0 & 0 \\
\hline Estilos de Aprendizagem & 27 & 1 & 1 \\
\hline Total & 1226 & 23 & 10 \\
\hline
\end{tabular}

Além desses achados, foi feito uso de outras referências citadas nos trabalhos encontrados, como, por exemplo, Vermunt (1998, 2005) e Zerbini (2007).

Há muitas definições e abordagens teóricas relacionadas aos Estilos de Aprendizagem. Para Vermunt (1998), Estilos de Aprendizagem consistem em um conjunto coerente de atividades de aprendizagem que os indivíduos utilizam frequentemente, de acordo com a orientação e as concepções individuais de aprendizagem. Esse autor apresentou um modelo teórico de Estilos de Aprendizagem, o Modelo de Regulação dos Processos de Aprendizagem, cuja abordagem integra as noções de aprendizagem puramente cognitivista e a construcionista, e é composto por quatro dimensões hipotéticas de aprendizagem: a) estratégias de processamento de informação; b) estratégias regulatórias de aprendizagem; c) modelo mental de aprendizagem; e d) orientações para a aprendizagem.

Berings et al. (2005) definem os Estilos de Aprendizagem como uma tendência a usar uma determinada combinação de atividades para aprender que deriva de uma combinação de preferências e capacidades percebidas. Esse modelo teórico foi desenvolvido especificamente para o estudo de Estilos de Aprendizagem no contexto do trabalho e recebeu o nome de Modelo de Interação de Comportamento de Aprendizagem no Trabalho. Segundo ele, os Estilos de Aprendizagem são uma tendência a usar uma combinação particular de atividades 
implícitas e explícitas (ligadas a fatores individuais e ambientais, respectivamente) que uma pessoa pode e gosta de desempenhar. Tais atividades de aprendizagem, nomeadas mentais ou expostas, realizadas de maneira individual (intrapessoal) ou com outras pessoas (interpessoal), definem as dimensões dos Estilos de Aprendizagem.

Para Warr e Allan (1998) e Zerbini (2007), Estilos de Aprendizagem são as preferências do estudante referentes aos aspectos contextuais e as maneiras de estudar; compreendem a preferência dos indivíduos por determinados comportamentos de estudo e por aspectos do contexto em que este ocorre. São preferências focadas no contexto e nas atividades de aprendizagem, tais como: nível de ruído e temperatura do ambiente ao estudar, horário de preferência de estudo, forma de estudo (individual, em grupo).

Salles (2007) observa que existe uma produção de pesquisas voltadas para o trabalho e para as organizações, que abordam os Estilos de Aprendizagem, mas a minoria delas utiliza medidas desenvolvidas exclusivamente para o contexto educacional. Brant (2014) afirma que há algumas pesquisas estrangeiras evidenciando a influência dos Estilos de Aprendizagem em resultados finais de treinamento à distância. Contudo, a análise da produção científica nacional em Estilos de Aprendizagem mostra que predominam fortemente os estudos na área educacional. As pesquisas voltadas para o contexto do trabalho e IES são raras e, em sua maioria, apresentam inconsistência na descrição do método e na apresentação de resultados. Além disso, aponta que não encontrou estudos que utilizaram as medidas disponíveis para a verificação das relações entre os Estilos de Aprendizagem e as características individuais e de contexto no campo específico da EAD, que é o campo de estudo desta de pesquisa.

Abaixo, a Tabela 6 apresenta os principais achados da revisão de literatura acerca dos Estilos de Aprendizagem. 
Tabela 6. Revisão de literatura para Estilos de Aprendizagem.

\begin{tabular}{|c|c|c|c|c|c|c|}
\hline Autores & Título & Área & País & Objetivos & $\begin{array}{l}\text { Instrumento e } \\
\text { amostra }\end{array}$ & Resultados \\
\hline Sahin (2008) & $\begin{array}{l}\text { Relações entre } \\
\text { características dos } \\
\text { alunos, incluindo os } \\
\text { Estilos de Aprendizagem } \\
\text { e as suas percepções e } \\
\text { satisfação em cursos } \\
\text { baseados na web no } \\
\text { Ensino Superior. }\end{array}$ & Educação & Turquia & $\begin{array}{l}\text { Investigar as } \\
\text { relações entre as } \\
\text { características dos } \\
\text { alunos e sua } \\
\text { percepção e } \\
\text { satisfação com o } \\
\text { ensino à distância e } \\
\text { cursos baseados na } \\
\text { web de uma } \\
\text { universidade } \\
\text { estadual. As } \\
\text { características dos } \\
\text { alunos estudadas } \\
\text { são sexo, idade, } \\
\text { escolaridade, estilo } \\
\text { de aprendizagem, } \\
\text { número de cursos } \\
\text { baseados na Web } \\
\text { que realizou } \\
\text { anteriormente, } \\
\text { percepção de } \\
\text { ciência, e horas } \\
\text { trabalhadas por } \\
\text { semana. }\end{array}$ & $\begin{array}{l}\text { Educação a Distance } \\
\text { Education Learning } \\
\text { Environment Survey } \\
\text { (DELES) Walker } \\
\text { (2003). } \\
\text { Inventário de Estilo } \\
\text { de Aprendizagem } \\
\text { (LSI) (Kolb, 1999). } \\
\text { Amostra: estudantes } \\
\text { de ensino superior à } \\
\text { distância que fazem } \\
\text { uso de ferramentas } \\
\text { da Web. Foram cerca } \\
\text { de } 350 \text { participantes } \\
\text { de diferentes cursos. }\end{array}$ & $\begin{array}{l}\text { - Estudantes do sexo masculino preferem a conceituação } \\
\text { abstrata (CA) mais do que o sexo feminino, bem como } \\
\text { os estudante mais velhos (acima de } 21 \text { anos) em } \\
\text { relação aos mais novos (18-21); } \\
\text { - O gênero e a idade não foram estatisticamente } \\
\text { significativos em termos de preferências de estilo de } \\
\text { aprendizagem, quando a escolaridade era a mesma; } \\
\text { - Estudantes de Agricultura, Negócios, Engenharia, } \\
\text { Artes e Ciência e Medicina Veterinária preferido CA, } \\
\text { enquanto Estudantes de Educação preferem } \\
\text { experiência concreta (EC); } \\
\text { - A escolaridade é um importante preditor do estilo de } \\
\text { aprendizagem; } \\
\text { - Apesar de que havia entre diferenças médias sexos e } \\
\text { idade e os estilos, essas diferenças não foram tão } \\
\text { significativas quanto em relação à escolaridade }\end{array}$ \\
\hline
\end{tabular}


Tabela 6. Revisão de literatura para Estilos de Aprendizagem (continuação).

\begin{tabular}{|c|c|c|c|c|c|c|}
\hline Autores & Título & Área & País & Objetivos & Instrumento e Amostra & Resultados \\
\hline $\begin{array}{l}\text { Richardson } \\
\text { (2010) }\end{array}$ & $\begin{array}{l}\text { Abordagens para o } \\
\text { estudo, as } \\
\text { concepções de } \\
\text { aprendizagem e } \\
\text { Estilos de } \\
\text { Aprendizagem em } \\
\text { ensino superior }\end{array}$ & Educação & Inglaterra & $\begin{array}{l}\text { Estilos de } \\
\text { Aprendizagem têm } \\
\text { interpretado de } \\
\text { diferentes maneiras, } \\
\text { porém, } \\
\text { tradicionalmente têm } \\
\text { sido considerados } \\
\text { como relativamente } \\
\text { estável. Em } \\
\text { contrapartida, a } \\
\text { perspectiva das } \\
\text { "abordagens para a } \\
\text { aprendizagem do } \\
\text { aluno" tende a } \\
\text { assumir que as } \\
\text { preferências para } \\
\text { estudar são } \\
\text { conduzidas pelo } \\
\text { contexto. O artigo } \\
\text { defende uma tese de } \\
\text { reaproximação entre } \\
\text { essas duas tradições. }\end{array}$ & $\begin{array}{l}\text { Artigo puramente teórico, } \\
\text { não faz uso de instrumentos, } \\
\text { apenas uma reflexão teórica } \\
\text { com base nos autores Meyer } \\
\text { e Boulton-Lewis, e } \\
\text { Vermunt. }\end{array}$ & $\begin{array}{l}\text { - As abordagens dos alunos para estudar no ensino } \\
\text { superior podem estar relacionadas tanto às suas } \\
\text { percepções do seu ambiente acadêmico quanto às } \\
\text { suas concepções de aprendizagem e suas } \\
\text { concepções de si mesmos como aprendizes. } \\
\text { Vermunt }(1996,2005) \text { sempre se distanciou da ideia } \\
\text { de que o seu conceito de Estilos de Aprendizagem } \\
\text { implica alguns traços relativamente permanentes. } \\
\text { - Uma série de estudos têm encontrado pouca } \\
\text { evidência de alterações nas concepções nos modelos } \\
\text { mentais de aprendizagem dos alunos de um ano } \\
\text { letivo para o outro. Estes achados sugerem que as } \\
\text { concepções ou modelos mentais de aprendizagem } \\
\text { dos alunos são relativamente estáveis. } \\
\text { - Os modelos mentais do ILS, instrumento de } \\
\text { Vermunt, já provou ser uma ferramenta robusta e já } \\
\text { foi usada separadamente. }\end{array}$ \\
\hline
\end{tabular}


Tabela 6. Revisão de literatura para Estilos de Aprendizagem (continuação).

Autores

Título

Área

País

Objetivos

\section{Os estilos}

preferenciais de

Brown, Zoghi

Williams,

Jaberzadeh,

Roller, Palermo,

McKenna,

Wright, et

al.(2009) aprendizagem de estudantes da área

da saúde são preditores de suas

atitudes acerca do

e-learning?
Determinar se os

estilos preferenciais

de aprendizagem de

Educação Austrália

estudantes da área da saúde são preditores de suas atitudes no e-

learning.
Índice de Estilos de

Aprendizagem (ILS) (Felder

\& Soloman, 1988)

Ambiente de Aprendizado

on-line Pesquisa (OLES)

(Trinidad, Aldridge \&

Fraser, 2005)

Amostra: 2885 alunos

matriculados em 10

diferentes programas de

ciências da saúde

universidade australiana.

Um total de 822

questionários utilizáveis

foram devolvidos gerando

uma taxa de resposta de 29,3

$\%$. Utilizando-se o programa

SPSS, realizou-se uma

análise de regressão linear
- 44\% dos estudantes das ciências da saúde uma preferência por serem alunos ativos, $60 \%$ como alunos sensoriais e $64 \%$ como alunos sequenciais.

- Para as subescalas efetivas do OLES, as dimensões de Estilos de Aprendizagem ativo-reflexivo e Sensoriamento-intuitivo do ILS foram os preditores mais frequentes de atitudes dos estudantes de

ciências da saúde em relação ao e-learning.

- Parece que os Estilos de Aprendizagem dos estudantes de ciências da saúde (medido pelo ILS) pode ser usado apenas de forma limitada como um preditor das atitudes dos estudantes em relação à elearning.

- No entanto, os educadores ainda deveriam

considerar os Estilos de Aprendizagem do estudante no contexto de uso da tecnologia para propósitos instrucionais. 
Tabela 6. Revisão de literatura para Estilos de Aprendizagem (continuação).

\begin{tabular}{|c|c|c|c|c|c|c|}
\hline Autores & Título & Área & País & Objetivos & Instrumento e Amostra & Resultados \\
\hline Battalio (2009) & $\begin{array}{l}\text { Sucesso na } \\
\text { Educação a } \\
\text { Distância: Os } \\
\text { Estilos de } \\
\text { Aprendizagem e os } \\
\text { Múltiplos Formatos } \\
\text { importam? }\end{array}$ & Educação & $\begin{array}{l}\text { Estados } \\
\text { Unidos }\end{array}$ & $\begin{array}{l}\text { Determinar a } \\
\text { extensão em que o } \\
\text { estilo de } \\
\text { aprendizagem de } \\
\text { cada estudante está } \\
\text { associado com o } \\
\text { sucesso em ambientes } \\
\text { virtuais de } \\
\text { aprendizagem on- } \\
\text { line, especialmente } \\
\text { quando as } \\
\text { ferramentas de apoio } \\
\text { disponíveis para } \\
\text { estudantes são } \\
\text { controladas. }\end{array}$ & $\begin{array}{l}\text { Index of Learning Styles } \\
\text { (Felder \& Soloman, 1991) } \\
\text { Questionário demográfico } \\
\text { Questionário sobre a opinião } \\
\text { do aluno sobre o curso a } \\
\text { cada final de semestre. } \\
\text { Amostra: } 120 \text { estudantes de } \\
\text { curso técnico em } \\
\text { comunicação }\end{array}$ & $\begin{array}{l}\text { - Os alunos reflexivos foram encontrados para ser os } \\
\text { alunos mais bem-sucedidos no ambiente virtuais, } \\
\text { com bom desempenho tanto na versão colaborativa } \\
\text { tanto quanto a versão auto-dirigida. } \\
\text { - Alunos sequenciais superaram os alunos globais. } \\
\text { - Os Estilos de Aprendizagem não foram um fator } \\
\text { significativo nos cursos de verão. }\end{array}$ \\
\hline $\begin{array}{l}\text { Nastanski e Slick } \\
\text { (2008) }\end{array}$ & $\begin{array}{l}\text { Estilos de } \\
\text { Aprendizagem e a } \\
\text { sala de aula on-line: } \\
\text { Implicações para } \\
\text { estudantes de } \\
\text { administração }\end{array}$ & Educação & $\begin{array}{l}\text { Estados } \\
\text { Unidos }\end{array}$ & $\begin{array}{l}\text { Examinar as } \\
\text { preferências de estilo } \\
\text { de aprendizagem de } \\
\text { estudantes de } \\
\text { administração em } \\
\text { EAD usando } \\
\text { ambientes virtuais de } \\
\text { ensino e determinar } \\
\text { se uma diferença } \\
\text { significativa entre as } \\
\text { notas e as taxas de } \\
\text { conclusão de curso } \\
\text { existe entre } \\
\text { estudantes quando } \\
\text { eles são classificados } \\
\text { de acordo com seus } \\
\text { Estilos de } \\
\text { Aprendizagem. }\end{array}$ & $\begin{array}{l}\text { Inventário de Estilos de } \\
\text { Aprendizagem (Kolb, 2005). } \\
\text { Dados quantitativos para } \\
\text { identificar a taxa de } \\
\text { conclusão de curso e as } \\
\text { notas individuais. } \\
\text { Amostra: } 344 \text { estudantes de } \\
\text { administração em EAD de } \\
\text { uma universidade no sudeste } \\
\text { dos Estados Unidos }\end{array}$ & $\begin{array}{l}\text {-Há uma diferença significativa entre a preferência } \\
\text { pelo Estilo de Aprendizagem Divergente } \\
\text { comparado aos estilos Assimilador, Acomodativo } \\
\text { e Convergente. } \\
\text {-20\% dos respondentes da tinha preferência pelo } \\
\text { estilo de aprendizagem Convergente. Os } \\
\text { entrevistados com esta preferência estilo de } \\
\text { aprendizagem parecem ser um pouco menos } \\
\text { prováveis ser bem-sucedido em um ambiente de } \\
\text { ensino à distância. }\end{array}$ \\
\hline
\end{tabular}


Tabela 6. Revisão de literatura para Estilos de Aprendizagem (continuação).
Autores
Título
Área
País
Objetivos

Instrumento e Amostra

Resultados

A avaliação

psicométrica do

Klein, McCall,

Austin e Piterman

(2007)
Questionário

Estilos de

Aprendizagem:

versão de 40 itens
Investigar as

propriedades

psicométricas do

LSQ (versão de 40

itens), pois parece

que não há nenhum

estudo realizado para

investigar as

propriedades

psicométricas desta

medida disponível

comercialmente.
Foi utilizado o questionário

de Estilos de Aprendizagem

(LSQ) (Honey \& Mumford,

2000) - versão breve de 40

itens.

- Os resultados indicaram que o LSQ (versão de 40item) tem pouca confiabilidade e validade e, portanto, exige mais desenvolvimento e avaliação psicométrica. 
Tabela 6. Revisão de literatura para Estilos de Aprendizagem (continuação). Autores Título Área País Objetivos

Construção e evidências de Silva (2011) validade e precisão de escala de Estilos de Aprendizagem

Psicologia da
Educação em Universitários
Construir e verificar evidências de

validade e precisão

de uma escala de

Estilos de

Aprendizagem em

universitários
Modelo teórico de Estilos de

Aprendizagem Dunn, Dunn e Price (1984), composto de 22 elementos.

Amostra: 510 estudantes de ambos os sexos, matriculados em diversos cursos de uma IES do Estado de São Paulo.
- O instrumento mostrou-se válido e confiável para avaliar os Estilos de Aprendizagem em universitários.
Investigar os

estilos e

Estratégias de

Aprendizagem de

universitários,

com o objetivo de

avaliar uma

possível interação

Estilos e Estratégias

Silva (2012)

de Aprendizagem

Psicologia

de Estudantes

da

Universitários

Educação entre os dois

constructos e

também comparar

o tipo de estilos e

de estratégia de

aprendizagem dos

participantes em

função da área de

conhecimento, do

curso e do sexo

dos participantes
- No tocante às Estratégias de Aprendizagem,

Índice de Estilos de Aprendizagem

(Felder \& Soloman, 1991)

Escala de Avalição de Estratégias

de Aprendizagem em Universitários

Santos \& Boruchovitch, 2001).

Amostra: 352 estudantes de

diversos cursos de graduação de

uma instituição de ensino superior

particular do interior de São Paulo

constatou-se que há uma ordem hierárquica no uso

das mesmas: preferencialmente as estratégias de

autorregulação dos recursos internos e contextuais,

seguidas pelas de autorregulação cognitiva e

metacognitivas e, por último, as destinadas à

autorregulação social.

- Não foi apresentada correlação suficientemente

robusta entre estilos es Estratégias de

Aprendizagem.

- Foram indicadas diferenças significantes quanto as

variáveis: área de conhecimento, curso e gênero do participante. 
Tabela 6. Revisão de literatura para Estilos de Aprendizagem (continuação).

\begin{tabular}{|c|c|c|c|c|c|c|}
\hline Autores & Título & Área & País & Objetivos & Instrumento e Amostra & Resultados \\
\hline Salles (2007) & $\begin{array}{l}\text { Estilos de } \\
\text { Aprendizagem no } \\
\text { Trabalho: Análise e } \\
\text { Construção de } \\
\text { Medidas. }\end{array}$ & $\begin{array}{l}\text { Psicologia } \\
\text { Organizaci } \\
\text { onal e do } \\
\text { Trabalho }\end{array}$ & Brasil & $\begin{array}{l}\text { (1) buscar um melhor } \\
\text { entendimento sobre } \\
\text { os Estilos de } \\
\text { Aprendizagem e suas } \\
\text { relações com o } \\
\text { contexto de trabalho, } \\
\text { verificando a } \\
\text { necessidade da } \\
\text { construção de uma } \\
\text { medida de Estilos de } \\
\text { Aprendizagem no } \\
\text { contexto de trabalho } \\
\text { e (2) construção e } \\
\text { validação de uma } \\
\text { medida de Estilos de } \\
\text { Aprendizagem no } \\
\text { contexto de trabalho. }\end{array}$ & $\begin{array}{l}\text { Base teórica de Berings et al. } \\
(2005) \text {. } \\
\text { Amostra: } 503 \text { trabalhadores de } \\
\text { uma organização pública. }\end{array}$ & $\begin{array}{l}\text { - Foram encontradas } 57 \text { medidas de Estilos de } \\
\text { Aprendizagem, das quais } 12 \text { foram utilizadas no } \\
\text { contexto de trabalho. } \\
\text {-Em relação ao instrumento, encontrou-se solução de } \\
\text { dois fatores, interpretadas como sendo relativas às } \\
\text { preferências por aprender sozinho e com outras } \\
\text { pessoas, com boa qualidade psicométrica. } \\
\text { - Foi elaborado um instrumento de } 22 \text { itens. }\end{array}$ \\
\hline Brant (2014) & $\begin{array}{l}\text { Estudo Multinível } \\
\text { de Antecedentes do } \\
\text { Impacto no } \\
\text { Trabalho e da } \\
\text { Persistência/Evasão } \\
\text { em Treinamentos a } \\
\text { Distância }\end{array}$ & $\begin{array}{l}\text { Psicologia } \\
\text { Organizaci } \\
\text { onal e do } \\
\text { Trabalho }\end{array}$ & Brasil & $\begin{array}{l}\text { O objetivo deste } \\
\text { estudo foi analisar os } \\
\text { antecedentes de } \\
\text { efetividade de } \\
\text { treinamento e da } \\
\text { persistência/Evasão } \\
\text { em cursos oferecidos } \\
\text { na modalidade a } \\
\text { distância no contexto } \\
\text { de trabalho }\end{array}$ & $\begin{array}{l}\text { Instrumento de Impacto de } \\
\text { Treinamento no Trabalho } \\
\text { (Abbad, 1999) } \\
\text { Orientação Cultural para } \\
\text { Aprendizagem (Rabelo, 2001). } \\
\text { Amostra: } 1002 \text { funcionários de } \\
\text { uma empresa pública que tem } \\
\text { como objetivo modernizar e dar } \\
\text { agilidade a setores estratégicos } \\
\text { da Administração Pública } \\
\text { Brasileira. }\end{array}$ & $\begin{array}{l}\text { - Os Estilos de Aprendizagem, as crenças em sistema } \\
\text { de treinamento e a cultura de aprendizagem são } \\
\text { preditores significativos de percepções de mudanças } \\
\text { no desempenho no trabalho provocados pelo } \\
\text { treinamento e são fatores influentes na decisão de } \\
\text { Evasão. } \\
\text { - A cultura de aprendizagem seria capaz de alterar } \\
\text { substancialmente as relações entre aqueles estilos e } \\
\text { crenças e estes desempenhos. }\end{array}$ \\
\hline
\end{tabular}


Dos artigos lidos, quatro são de origem nacional e os demais foram publicados na Turquia, Austrália, Estados Unidos e Inglaterra. Os instrumentos utilizados nos artigos foram, em primeiro lugar, o ILS - Índice de Estilos de Aprendizagem (Felder \& Silverman, 1988), utilizado em três estudos; em segundo lugar, o LSI - Inventário de Estilos de Aprendizagem (Kolb, 1985, 2005), utilizado em dois estudos; e em terceiro lugar o Questionário de Estilos de Aprendizagem (Honey \& Mumford, 2000), utilizado em um estudo. Os demais estudos eram de origem teórica, ou tinham como objetivo a construção e validação de uma medida de Estilos de Aprendizagem. Em relação às medidas citadas acima, somente o Questionário de Estilos de Aprendizagem foi validado no estudo, pois era esse o objetivo do mesmo. Os demais foram utilizados nos estudos, mas não foram submetidos à validação estatística. Cabe destacar também que somente os estudos do Brasil tinham como objetivo a construção e validação de instrumento.

Em relação às áreas do conhecimento, seis artigos são da área da Educação e quatro da Psicologia, sendo que dentre esses quatro, dois são da Psicologia Educacional e dois da Psicologia Organizacional e do Trabalho. Portanto, pode-se ressaltar que a produção científica de Estilos de Aprendizagem na área da Psicologia ainda é escassa em estudos internacionais.

Levando em consideração a POT, há a produção de Salles (2007) e Brant (2014) que se aprofundam no estudo de Estilos de Aprendizagem, sendo, portanto, as principais referências do presente estudo. Brant (2014) realizou uma revisão de literatura focada em Estilos de Aprendizagem, encontrando diversos instrumentos e definições. A partir disso, buscou evidências de validade desses instrumentos para auxiliar nos objetivos de sua tese, dentre eles a construção de um instrumento de Estilos de Aprendizagem no contexto do trabalho para ações educacionais ofertadas à distância. Os achados da pesquisa estão abaixo na Tabela 7. 
Tabela 7. Instrumentos de Estilos de Aprendizagem.

\begin{tabular}{|c|c|c|c|}
\hline Modelo Teórico & Instrumentos & \begin{tabular}{|c|} 
Exemplo de Itens \\
\end{tabular} & $\begin{array}{c}\text { Críticas } \\
\end{array}$ \\
\hline $\begin{array}{l}\text { Modelo de estilos cognitivos (Anthony } \\
\text { Gregorc, 1985): baseado na teoria de } \\
\text { hemisférios cerebrais. Todos os } \\
\text { indivíduos têm dois tipos de } \\
\text { preferenciais para aprender: percepção } \\
\text { (concreta/abstrata); ordenação } \\
\text { (aleatória/sequencial). }\end{array}$ & $\begin{array}{l}\text { Delineador de estilos cognitivos de } \\
\text { Gregorc (1982): } 20 \text { séries de descrições } \\
\text { de comportamento, indicando as mais e } \\
\text { as menos preferidas. LSI }(1992,1996) \\
\text { /LSQ (1979). }\end{array}$ & $\begin{array}{l}\text { For each word in a column, use the } \\
\text { values } 1-4 \text { to rank that word. } 4 \text { indicates } \\
\text { what is most descriptive of you, } 1 \\
\text { indicates what is least descriptive of } \\
\text { you. } \\
\text { a) Imaginative() } \\
\text { b) Investigative() } \\
\text { c) Realistic() } \\
\text { d) Analytical() }\end{array}$ & $\begin{array}{l}\text { Os instrumentos apresentam problemas } \\
\text { de validade e de fidedignidade. } \\
\text { Falta de evidências empíricas sobre a } \\
\text { influência genética no que se refere à } \\
\text { personalidade e aos Estilos de } \\
\text { Aprendizagem. }\end{array}$ \\
\hline $\begin{array}{l}\text { Modelo de Estilos de Aprendizagem } \\
\text { (Rita Dunn \& Kenneth Dunn, 1975): } \\
\text { Estilo de aprendizagem é a maneira pela } \\
\text { qual os indivíduos começam a } \\
\text { concentrar-se, processar e reter novos } \\
\text { conteúdos de aprendizagem. É uma } \\
\text { combinação de várias características } \\
\text { biológicas e experienciais que } \\
\text { contribuem para a aprendizagem. }\end{array}$ & $\begin{array}{l}\text { Learning Style Inventory (LSI): avalia } \\
\text { vinte e dois fatores que representam } \\
\text { fatores ambientais, emocionais, } \\
\text { sociológicos, psicológicos e físicos. } \\
\text { Productivity Environmental Preference } \\
\text { Survey ((PEPS) é a versão para adultos } \\
\text { do LSI. O PEPS apresenta } 100 \text { questões } \\
\text { em uma escala de concordância de } 5 \\
\text { pontos. }\end{array}$ & $\begin{array}{l}\text { I study best when the lights are dim. } \\
\text { When I do well at school, grown-ups in } \\
\text { my family are proud of me. } \\
\text { I like to listen to music while I'm } \\
\text { studying. }\end{array}$ & $\begin{array}{l}\text { Os instrumentos não avaliam as } \\
\text { habilidades cognitivas; o foco está } \\
\text { somente na influência do ambiente. } \\
\text { Os instrumentos apresentam problemas } \\
\text { de validade e de fidedignidade. }\end{array}$ \\
\hline $\begin{array}{l}\text { Modelo de estilos cognitivos (Riding \& } \\
\text { Rayner, 1998): Foco no controle } \\
\text { cognitivo e nos processos cognitivos. }\end{array}$ & $\begin{array}{l}\text { Cognitive Styles Analysis (CSA) - } \\
\text { Escala Bidimensional que apresenta } \\
\text { tarefas cognitivas: (i) holística/analítica; } \\
\text { e (ii) verbal/imagem. } \\
\text { Os } 48 \text { itens do teste são respondidos via } \\
\text { computador. }\end{array}$ & $\begin{array}{l}\text { Consistem em estímulos visuais e } \\
\text { verbais. } \\
\text { Os itens de teste no CSA para a } \\
\text { dimensão holística/analítica são todos } \\
\text { visuais: } \\
\text { Is shape } X \text { the same as shape } Y \text { ? } \\
\text { Is shape X contained in shape } Y \text { ? } \\
X \text { e Y são figures apresentadas na tela } \\
\text { do computador. } \\
\text { Os itens para a dimensão verbal/imagem } \\
\text { são todos verbais. }\end{array}$ & $\begin{array}{l}\text { Há poucos estudos com o modelo. } \\
\text { Os resultados publicados indicam que } \\
\text { há problemas de validade e } \\
\text { fidedignidade da medida. }\end{array}$ \\
\hline
\end{tabular}


Tabela 7. Instrumentos de Estilos de Aprendizagem (continuação).

\begin{tabular}{|c|c|c|c|}
\hline Modelo Teórico & Instrumentos & Exemplo de Itens & Críticas \\
\hline $\begin{array}{l}\text { Myers-Briggs Type Indicator (MBTI) } \\
\text { (1998): instrumento baseado na teoria } \\
\text { de tipos psicológicos de Jung. }\end{array}$ & $\begin{array}{l}\text { Myers-Briggs Type Indicator (MBTI) - } \\
\text { teste de escolha produzindo } 16 \text { tipos de } \\
\text { personalidade. } \\
\text { Versões de } 93,126 \text { e } 50 \text { itens. } \\
\text { Pontuações são atribuídas para produzir } \\
\text { uma das } 16 \text { combinações de } \\
\text { preferências }\end{array}$ & $\begin{array}{l}\text { Which kind of mental process leads your } \\
\text { Outside World Orientation? } \\
\text { (a) Judging } \\
\text { (b) Perceiving } \\
\text { Are you more intrigued by: } \\
\text { (a) facts } \\
\text { (b) similes } \\
\text { Are you usually rather: } \\
\text { (a) quick to agree to a time } \\
\text { (b) reluctant to agree to a time }\end{array}$ & $\begin{array}{l}\text { Não há evidências claras de como os } \\
\text { tipos são estáveis ao longo da vida de } \\
\text { um indivíduo, nem uma compreensão } \\
\text { clara de como a dinâmica de cada tipo } \\
\text { pode impactar a aprendizagem. } \\
\text { A validade de construto não é } \\
\text { consensual. } \\
\text { Tipos psicológicos não predizem } \\
\text { desempenho. }\end{array}$ \\
\hline $\begin{array}{l}\text { Modelo Híbrido de Aprendizagem e } \\
\text { Personalidade (Chris Jackson, 2002): Os } \\
\text { Estilos de Aprendizagem são um } \\
\text { subconjunto da personalidade; possuem } \\
\text { uma base biológica e constituem a parte } \\
\text { aprendida da personalidade. }\end{array}$ & $\begin{array}{l}\text { Learning Styles Profiler (LSP): } 75 \text { itens } \\
\text { avaliados em escala de } 3 \text { pontos (yes; } \\
\text { no; can't decide). }\end{array}$ & $\begin{array}{l}\text { Do you generally do and say things } \\
\text { without stopping to think (impulsivity)? } \\
\text { Do you often feel that you } \\
\text { have little influence over the things that } \\
\text { happen to you (emotional } \\
\text { independence)? } \\
\text { Can you always fully be relied upon } \\
\text { (responsibility)? } \\
\text { Do you like work that involves action } \\
\text { rather than profound thought and study } \\
\text { (practicality)? }\end{array}$ & $\begin{array}{l}\text { Suporte teórico não é rígido; poucos } \\
\text { estudos verificaram a estabilidade da } \\
\text { medida. }\end{array}$ \\
\hline $\begin{array}{l}\text { Teoria da aprendizagem experiencial } \\
\text { (David Kolb, 1984): } \\
\text { O ciclo de aprendizagem expressa } \\
\text { quatro estágios: as experiências } \\
\text { concretas fornecem a base para as } \\
\text { observações e reflexões. As observações } \\
\text { e reflexões são assimiladas e } \\
\text { disseminadas, produzindo conceitos } \\
\text { abstratos que podem ser testados } \\
\text { ativamente. }\end{array}$ & $\begin{array}{l}\text { Learning Style Inventory (LSI): } 12 \\
\text { frases que descrevem as preferências de } \\
\text { aprendizagem, ancoradas em } 1=\text { "se } \\
\text { parece muito comigo" a } 4 \text { = "não se } \\
\text { parece nada comigo". } \\
\text { Formas dialéticas de enfrentar } \\
\text { (experimentação ou reflexão) e de } \\
\text { transformar a experiência (observação e } \\
\text { experimentação ativa) } \\
\text { Experiência concreta (CE) } \\
\text { Observação Reflexiva (RO) } \\
\text { Conceituação abstrata(AC) } \\
\text { Experimentação Ativa(AE). }\end{array}$ & $\begin{array}{l}\text { Eu aprendo melhor quando: } \\
\text { Considero os meus sentimentos } \\
\text { Considero as minhas observações } \\
\text { Considero as minhas ideias } \\
\text { Posso experimentar as coisas por mim } \\
\text { mesmo. }\end{array}$ & $\begin{array}{l}\text { O instrumento apresenta problemas de } \\
\text { validade e de fidedignidade. } \\
\text { Há dúvidas se os } 12 \text { itens cobrem a } \\
\text { dimensionalidade do construto. }\end{array}$ \\
\hline
\end{tabular}


Tabela 7. Instrumentos de Estilos de Aprendizagem (continuação).

\begin{tabular}{|c|c|c|c|}
\hline $\begin{array}{c}\text { Modelo Teórico } \\
\end{array}$ & Instrumentos & $\begin{array}{c}\text { Exemplo de Itens } \\
\end{array}$ & Críticas \\
\hline $\begin{array}{l}\text { Learning Styles Questionnaire (LSQ) } \\
\text { (Peter Honey e Alan Mumford, 2000): } \\
\text { As pessoas preferem métodos diferentes } \\
\text { de aprendizagem, dependendo da } \\
\text { situação e do nível de experiência, } \\
\text { portanto, eles se movem entre os quatro } \\
\text { modos de aprendizagem descritos por } \\
\text { Kolb (1984), ao invés de estar } \\
\text { predominantemente preso a um único. } \\
\text { Atitudes e comportamentos que } \\
\text { determinam forma preferida de um } \\
\text { indivíduo de aprendizagem. }\end{array}$ & $\begin{array}{l}\text { O LSQ consiste de } 80 \text { itens que sondam } \\
\text { as preferências de quatro Estilos de } \\
\text { Aprendizagem com } 20 \text { itens para cada } \\
\text { estilo (ativistas, reflexivos, teóricos e } \\
\text { pragmáticos). } \\
\text { Os itens são avaliados em escala Likert } \\
\text { de concordância. }\end{array}$ & $\begin{array}{l}\text { I like to follow a self-disciplined } \\
\text { approach, establish clear processes and } \\
\text { logical thinking patterns. } \\
\text { I take care over the interpretation of } \\
\text { data and avoid jumping to conclusions. }\end{array}$ & $\begin{array}{l}\text { O instrumento apresenta problemas de } \\
\text { validade e de fidedignidade. } \\
\text { Há dúvidas se pode predizer } \\
\text { desempenho. }\end{array}$ \\
\hline $\begin{array}{l}\text { Cognitive Style Index (CSI) (Allinson \& } \\
\text { Hayes, 2000): Forma preferida das } \\
\text { pessoas levantarem, processarem e } \\
\text { avaliarem as informações. }\end{array}$ & $\begin{array}{l}\text { Instrumento com } 38 \text { itens avaliados em } \\
\text { escala de três pontos (yes; no; can’t } \\
\text { decide), com dois fatores de uma única } \\
\text { dimensão (a intuição em um extremo e a } \\
\text { análise no outro). }\end{array}$ & $\begin{array}{l}\text { I prefer complex issues than simple } \\
\text { ones. } \\
\text { I like to do something that could } \\
\text { challenge my thinking. }\end{array}$ & $\begin{array}{l}\text { Foram encontrados resultados que } \\
\text { mostram que os dois fatores são } \\
\text { correlacionados. }\end{array}$ \\
\hline $\begin{array}{l}\text { Index of Learning Styles (Felder \& } \\
\text { Solomon, 1991): Mede as preferências } \\
\text { dos alunos em relação ao estilo de } \\
\text { aprendizagem por meio de quatro } \\
\text { escalas, que por sua vez, têm duas } \\
\text { dimensões de aprendizagem: ativo- } \\
\text { reflexivo, inteligível-intuitivo, visual- } \\
\text { verbal, e sequencial-global. }\end{array}$ & $\begin{array}{l}\text { Index of Learning Styles (ILS): } \\
\text { Instrumento com } 44 \text { itens com escolha } \\
\text { ipsativa. }\end{array}$ & $\begin{array}{l}\text { I understand something better after I } \\
\text { (a) try it out. } \\
\text { (b) think it through. } \\
\text { I prefer to get new information in } \\
\text { (a) pictures, diagrams, graphs, or maps. } \\
\text { (b) written directions or verbal } \\
\text { information. }\end{array}$ & $\begin{array}{l}\mathrm{O} \text { instrumento apresenta problemas de } \\
\text { validade e de fidedignidade. }\end{array}$ \\
\hline
\end{tabular}


Tabela 7. Instrumentos de Estilos de Aprendizagem (continuação).

\begin{tabular}{|c|c|c|c|}
\hline $\begin{array}{l}\text { Modelo Teórico } \\
\end{array}$ & Instrumentos & $\begin{array}{c}\text { Exemplo de Itens } \\
\end{array}$ & Críticas \\
\hline $\begin{array}{l}\text { Study Skills Inventory for Students } \\
\text { (ASSIST) (Entwistle, 1990): Visa } \\
\text { avaliar as orientações e as abordagens } \\
\text { ao estudo de alunos do ensino superior. }\end{array}$ & $\begin{array}{l}\text { Escala composta por três seções: } \\
\text { 1. Concepções de aprendizagem } \\
\text { 2. Abordagens para estudar (escala de } \\
\text { concordância de } 5 \text { pontos): } \\
\square \text { profunda } \\
\square \text { superficial } \\
\square \text { estratégica } \\
\text { 3. Preferências por diferentes tipos de } \\
\text { curso e ensino, avaliados em escala de } \\
\text { três pontos (yes; no; can't decide), }\end{array}$ & $\begin{array}{l}\text { 1. Concepções de aprendizagem: } \\
\text { Building up knowledge by acquiring } \\
\text { facts and information. } \\
\text { Making sure you remember things well. } \\
\text { 2. Abordagens para estudar } \\
\square \text { profunda } \\
\text { I usually set out to understand for } \\
\text { myself the meaning of what we have to } \\
\text { learn. } \\
\square \text { superficial } \\
\text { I find I have to concentrate on just } \\
\text { memorising a good deal of what I have } \\
\text { to learn. } \\
\square \text { estratégica } \\
\text { I usually plan out my week's work in } \\
\text { advance, either on paper or in my head. } \\
\text { 3. Preferências por diferentes tipos de } \\
\text { curso e ensino: } \\
\text { exams which allow me to show that I've } \\
\text { thought about the course material for } \\
\text { myself. }\end{array}$ & $\begin{array}{l}\text { Foram encontradas evidências de } \\
\text { validade e de fidedignidade. } \\
\text { Base teórica pouco clara. }\end{array}$ \\
\hline $\begin{array}{l}\text { Modelo de Regulação dos Processos de } \\
\text { Aprendizagem (Vermunt, 1988): Os } \\
\text { Estilos de Aprendizagem são um } \\
\text { conjunto coerente de atividades de } \\
\text { aprendizagem que os indivíduos } \\
\text { utilizam frequentemente, de acordo com } \\
\text { a orientação e as concepções individuais } \\
\text { de aprendizagem. }\end{array}$ & $\begin{array}{l}\text { Inventory of Learning Styles (ILS) é um } \\
\text { instrumento com } 120 \text { itens avaliados por } \\
\text { meio de uma escala Likert de } 5 \text { pontos. }\end{array}$ & $\begin{array}{l}\text { I try to discover the similarities and } \\
\text { differences between the theories that are } \\
\text { dealt with in a course. } \\
\text { I study details thoroughly. }\end{array}$ & $\begin{array}{l}\text { Sua abordagem pode certamente ser } \\
\text { adaptada para uso em todos os contextos } \\
\text { de aprendizagem ao longo da vida }\end{array}$ \\
\hline
\end{tabular}


Tabela 7. Instrumentos de Estilos de Aprendizagem (continuação).

\begin{tabular}{|c|c|c|c|}
\hline $\begin{array}{c}\text { Modelo Teórico } \\
\end{array}$ & Instrumentos & $\begin{array}{c}\text { Exemplo de Itens } \\
\end{array}$ & Críticas \\
\hline $\begin{array}{l}\text { Mental self-government (MSG) } \\
\text { (Sternberg, 1997): O modelo MSG } \\
\text { deriva da teoria de autogoverno: } \\
\text { monárquica, hierárquica, oligárquico e } \\
\text { anárquico. Cada um desses aspectos do } \\
\text { governo é considerado necessário para a } \\
\text { autogestão. Estilo é a forma preferida de } \\
\text { utilizar as próprias capacidades. }\end{array}$ & $\begin{array}{l}\text { Thinking Styles Inventory (TSI): } 104 \\
\text { itens avaliados em escala de } \\
\text { concordância de } 1 \text { a } 7 .\end{array}$ & $\begin{array}{l}\text { When making decisions, I tend to rely } \\
\text { on my own ideas and ways of doing } \\
\text { things. } \\
\text { When faced with a problem, I use my } \\
\text { own ideas and strategies to solve } \\
\text { problems. } \\
\text { I like to play with my ideas and see how } \\
\text { far they go. }\end{array}$ & $\begin{array}{l}\text { Não há referência ao motivo da escolha } \\
\text { dos tipos de governo. } \\
\text { Há poucas evidências de validade e de } \\
\text { fidedignidade da medida. }\end{array}$ \\
\hline $\begin{array}{l}\text { Grasha-Riechmann Student Learning } \\
\text { Style Scales (GRSLSS): } \\
\text { Enfoca as atitudes dos alunos em } \\
\text { relação à aprendizagem, às atividades de } \\
\text { sala de aula, aos professores e aos } \\
\text { colegas. } \\
\text { As pessoas precisam ser "instigadas" } \\
\text { para aprender e isso pode ser feito } \\
\text { criando-se, deliberadamente um } \\
\text { descompasso entre seu estilo de } \\
\text { aprendizagem e os métodos de ensino. }\end{array}$ & $\begin{array}{l}\text { Learning Styles Survey: } 60 \text { itens } \\
\text { avaliados em escala de concordância de } \\
5 \text { pontos. }\end{array}$ & $\begin{array}{l}\text { I prefer to work by myself on } \\
\text { assignments in my courses. } \\
\text { I enjoy hearing what other students } \\
\text { think about issues raised in class. }\end{array}$ & $\begin{array}{l}\text { O instrumento apresenta problemas de } \\
\text { validade e de fidedignidade }\end{array}$ \\
\hline $\begin{array}{l}\text { Berings et al. (2005; 2007) } \\
\text { Estilos de Aprendizagem são a } \\
\text { tendência a usar uma combinação } \\
\text { particular de atividades implícitas e } \\
\text { explícitas, que uma pessoa pode e gosta } \\
\text { de desempenhar. }\end{array}$ & $\begin{array}{l}\text { On-the-job Learning Style } \\
\text { Questionnaire for the Nursing } \\
\text { Profession (OLSQN): } 42 \text { itens que } \\
\text { refletem seis diferentes situações de } \\
\text { aprendizagem no trabalho de } \\
\text { enfermeiros sete itens de respostas para } \\
\text { essas seis situações de aprendizagem. }\end{array}$ & $\begin{array}{l}\text { In the last two years I have developed } \\
\text { myself in the support of patients and } \\
\text { family; In the last two years I have } \\
\text { learned more about where I can find } \\
\text { reliable information sources; }\end{array}$ & $\begin{array}{l}\text { Inventariar as situações e as atividades } \\
\text { de aprendizagem para que se possa } \\
\text { medir as preferências de aprendizagem } \\
\text { de segmentos profissionais particulares; } \\
\text { conceituação vaga sobre uma ideia } \\
\text { central presente na definição de estilos } \\
\text { desses autores, a capacidade percebida. }\end{array}$ \\
\hline
\end{tabular}

Fonte: Brant (2014). 
Como pode-se observar, praticamente todos os instrumentos possuem problemas relacionados a validade e fidedignidade. Em alguns outros, há algumas lacunas referentes à própria definição de Estilos de Aprendizagem. Nota-se uma frágil base teórica na maioria dos estudos, o que pode influenciar na qualidade das medidas. Por fim, novamente evidencia-se a escassez de pesquisas sobre o tema, o que dificulta o desenvolvimento e adaptação das medidas já existentes, bem como propostas de novas medidas.

A autora afirma que, apesar do instrumento Index of Learning Styles ser pouco utilizado, é o que apresenta melhores evidências de validade, além de já ter sido utilizado no contexto educacional de ensino superior presencial e à distância. Esse último contexto, é o selecionado para o presente trabalho. Sendo assim, tal instrumento foi selecionado como base para a construção do instrumento de Estilos de Aprendizagem em contexto de ensino superior ofertado à distância.

Por fim, Warr e Allan (1998) atribuem a mesma importância para o estudo de Estilos e Estratégias de Aprendizagem, já que informações sobre preferências do indivíduo (Estilos) podem ser úteis para adaptar os procedimentos utilizados no evento instrucional. Porém, destacam a importância de diferenciar esses dois conceitos.

No próximo capítulo serão apresentadas as características metodológicas da presente pesquisa: os objetivos, os instrumentos utilizados, os procedimentos de coleta e análise de dados. Além disso, são caracterizadas a população, a amostra, a instituição participante e o curso-alvo. 


\section{CAPÍTULO 4. CARACTERÍSTICAS METODOLÓGICAS DA PESQUISA}

\section{Objetivo do capítulo 4}

O presente capítulo se propõe a descrever a delimitação do problema, a justificativa e os objetivos da pesquisa, apresentar as características da IES participante, a população e amostra, os instrumentos de medida, assim como os procedimentos de coleta e análise estatística dos dados.

\subsection{Delimitação do problema, objetivos de pesquisa e modelo de investigação}

Tendo como base a apreciação das questões empíricas que permeiam o campo literário nacional e estrangeiro em TD\&E, com foco no subsistema de avaliação de treinamento e em agendas de pesquisas de investigações anteriores que se voltaram a essa temática, o problema de pesquisa desse estudo foi delimitado.

A partir da revisão de literatura, percebe-se que os Estilos de Aprendizagem estão sendo pouco estudados na área de POT, sua conceituação não está bem definida, e os instrumentos que se propõem a medir o construto não possuem bons índices de validade. Além disso, por mais que alguma vezes seja estudado em conjunto com as Estratégias de Aprendizagem, as diferenças conceituais entre os construtos não estão traçadas claramente. Constata-se também a necessidade doe estudo dos Estilos de Aprendizagem no contexto de EaD e sua possível relação com a Evasão.

Em função disso, propõem-se os seguintes problemas de pesquisa:

1. Quais as diferenças e semelhanças conceituais e metodológicas entre Estratégias de Aprendizagem e Estilos de Aprendizagem?

2. É possível propor uma definição operacional mais adequada de Estilos de Aprendizagem, considerando o contexto de Ações Educacionais Ofertadas a Distância?

3. Os Estilos de Aprendizagem e as Estratégias de Aprendizagem se relacionam com a possibilidade do aluno se evadir de um curso na modalidade EaD?

A fim de responder às questões empíricas acima descritas, foram traçados os objetivos da pesquisa, apresentados a seguir. 


\section{Objetivo Geral}

Construir e verificar evidências de validade de um instrumento de medida de Estilos de Aprendizagem, bem como realizar a validade convergente com o instrumento de Estratégias de Aprendizagem, além de propor uma discussão conceitual acerca dos Estilos de Aprendizagem.

\section{Objetivos Específicos}

- Construir e verificar evidências de validade de um instrumento de Estilos de Aprendizagem, com base na definição de Zerbini (2007), e nos instrumentos de Vermunt (1998) e Brant (2014).

- Verificar evidências de validade da Escala de Estratégias de Aprendizagem (Martins, 2012).

- Analisar a relação entre o uso de Estratégias de Aprendizagem e Estilos de Aprendizagem com a possibilidade de Evasão do curso.

- Analisar diferenças entre dados sociodemográficos e utilização de Estratégias de Aprendizagem e Estilos de Aprendizagem.

- Realizar a validade convergente entre os instrumentos de Estratégias de Aprendizagem e Estilos de Aprendizagem, a fim de verificar as semelhanças e diferenças conceituais e metodológicas - referentes às medidas existentes e utilizadas.

- Propor uma discussão conceitual sobre Estilos de Aprendizagem.

\subsection{Características da instituição-alvo}

A Universidade de São Paulo - responsável pela oferta do curso a distância denominado "Licenciatura em Ciências" - integra o rol das instituições parceiras já estabelecidas para execução a presente pesquisa. Em virtude da colaboração da referida universidade em estudo posterior conduzido pela proponente, a instituição declarou seu desejo e aceite em manter a conjugação de esforços de pesquisa já iniciada.

A proposta inicial de trabalhar em âmbito dessa IES partiu de uma profissional que integra o corpo docente do departamento de Psicologia da Faculdade de Filosofia, Ciências e Letras FFCLRP-USP. A referida docente, por ter uma atuação intensa no curso "Licenciatura em Ciências" da USP, teceu a sugestão de que esta ação instrucional fosse também investigada. Dessa feita, foi solicitada ao corpo administrativo competente permissão para coleta e 
utilização de dados advindos do referido curso. Após o deferimento do pedido, foram iniciadas as ações metodológicas necessárias.

O curso "Licenciatura em Ciências", de feitio semipresencial, passou a ser ministrado pela USP visando satisfazer uma demanda de aperfeiçoamento nas etapas do Ensino Fundamental e Médio paulistas, e está incluso no Programa Universidade Virtual do Estado de São Paulo (UNIVESP). Por meio de tal iniciativa, a universidade em questão pretende fomentar a preparação de recursos humanos altamente qualificados que, consequentemente, concorrerão para o desenvolvimento da coletividade. Segundo informações constantes no site do referido curso, pelo fato de os modelos tradicionais de ensino superior presencial guardarem limitações no tocante a uma formação mais personalizada e flexível, a USP compreende que ações instrucionais ofertadas a partir das modalidades a distância ou semipresencial operam como alternativas factíveis e, neste sentido, não só contribuem para o processo de democratização do ensino nacional, bem como suplementam medidas governamentais de capacitação e qualificação dos professores do Ensino Fundamental.

O curso Licenciatura em Ciências destina-se ao preparo de indivíduos que desejam se tornar aptos à prática do magistério no Ensino Fundamental ou de docentes atuantes na Educação Básica. Atualmente, são oferecidas 360 vagas distribuídas entre polos estabelecidos em diversas cidades do estado de São Paulo, tais como: São Paulo, São Carlos, Ribeirão Preto, Piracicaba, Jaú, Lorena e Santos. Vale mencionar que a forma de ingresso no curso ocorre por meio de concurso vestibular efetivado pela Fundação Universitária para o Vestibular (FUVEST). A fim de cumprir as deliberações previstas na Resolução CoG n $^{\circ}$ $5539 / 2009$, bônus são adicionados nas notas da $1^{\mathrm{a}}$ e $2^{\mathrm{a}}$ fases de candidatos com o seguinte perfil:

- Professores sem curso superior completo, atuando em docência na Educação Básica nas redes públicas há pelo menos 2 anos - bônus: 12 \%;

- Portadores de diploma de conclusão de curso superior (público ou reconhecido), com experiência docente comprovada de, no mínimo, 2 anos na Educação Básica nas redes públicas, em qualquer área, e que não possuam licenciatura - bônus: 9 \%;

- Licenciados que, necessariamente, tenham experiência docente de pelo menos 2 anos em escolas das redes públicas - bônus: $6 \%$;

- Egressos do ensino médio, sem formação universitária, formados há, no mínimo, 10 anos - bônus: $3 \%$. 


\subsection{Características do curso}

$\mathrm{Na}$ Tabela 8, seguem informações referentes ao curso de Licenciatura em Ciências ofertado pela Universidade de São Paulo.

Tabela 8. Características do curso a ser avaliado.

\begin{tabular}{|c|c|c|c|c|}
\hline $\begin{array}{c}\text { Instituição } \\
\text { Ofertante }\end{array}$ & Curso & Objetivo geral & Estrutura & Conteúdos \\
\hline $\begin{array}{l}\text { Universidade } \\
\text { de São Paulo }\end{array}$ & $\begin{array}{l}\text { Licenciatura } \\
\text { em Ciências }\end{array}$ & $\begin{array}{l}\text { Habilitar professores } \\
\text { atuantes na área de } \\
\text { Ciências na etapa do } \\
\text { Ensino Fundamental. Tal } \\
\text { preparação a compreensão } \\
\text { abrangente e integrada das } \\
\text { Ciências da Natureza e, ao } \\
\text { mesmo tempo, a postura } \\
\text { como intelectual crítico e } \\
\text { reflexivo, apto a orientar e } \\
\text { estimular os alunos para o } \\
\text { aprendizado significativo } \\
\text { das ciências. }\end{array}$ & 48 meses módulos & $\begin{array}{l}\text { Atividades formativas são } \\
\text { desenvolvidas durante os } \\
\text { módulos estabelecidos, } \\
\text { um por semestre. }\end{array}$ \\
\hline
\end{tabular}

Tal como já foi explicitado, o evento instrucional ministrado pela USP, Licenciatura em Ciências, encontra-se organizado em 8 módulos, sendo que cada um deles apresenta duração de 1 semestre e é constituído por disciplinas ou temas de interesse. Há a possibilidade de que uma ou mais disciplinas/temas sejam ofertadas concomitantemente. As atividades formativas previstas - atividades web, leitura e encontros presenciais - contabilizam uma carga horária total de 2.835 horas, compreendendo:

- 405 horas presenciais dedicadas às Práticas como Componente Curricular;

- 403 horas ao Estágio Curricular Supervisionado;

- 210 horas destinadas às Atividades Acadêmico-Científico-Culturais;

- 1800 horas de atividades relacionadas com os Conteúdos Curriculares de Natureza Científico-Cultural, sendo 1470 horas desenvolvidas a distância.

A Tabela 9 apresenta de forma mais detalhada as temáticas desenvolvidas em cada módulo, assim como as respectivas cargas horárias. 
Tabela 9. Curso "Licenciatura em Ciências": estrutura e organização.

\begin{tabular}{|c|c|c|}
\hline Atividade & Tema & Carga Horária \\
\hline Capacitação Tutor & Capacitação geral do tutor no ambiente Moodle (AVA); & 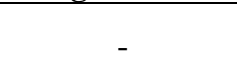 \\
\hline Capacitação Tutor/Disciplina & Capacitação específica do tutor na disciplina com professor da disciplina/tema; & - \\
\hline Capacitação Alunos & Capacitação dos alunos no Ambiente AVA; & - \\
\hline Módulo/Semestre 1: Terra e Universo & $\begin{array}{l}\text { Fundamentações matemáticas - Revisão e Cálculo; } \\
\text { Dinâmica do movimento dos corpos; } \\
\text { Matéria: organização e transformações; } \\
\text { Luz e ondas eletromagnéticas; } \\
\text { Céu; } \\
\text { Estrelas; } \\
\text { Evolução das Ciências: natureza dos conhecimentos científico, filosófico e do senso comum; } \\
\text { Laboratório Didático I; }\end{array}$ & $285 \mathrm{~h}$ \\
\hline $\begin{array}{l}\text { Módulo/Semestre 2: Ambiente na } \\
\text { Terra }\end{array}$ & $\begin{array}{l}\text { Atmosfera: composição e propriedades; ar e vida; perturbações e ação humana; } \\
\text { Hidrosfera: Composição e propriedades; fonte de recursos; perturbações e ação humana; ciclos; modelos } \\
\text { físicos. Geosfera: composição e propriedades; Solo e vida; } \\
\text { A Terra: clima e tempo; dias e estações do ano; determinantes geofísicos da organização da vida; } \\
\text { Fundamentações matemáticas; estudo de modelos; fundamentos de Estatística e Probabilidade; } \\
\text { Evolução das Ciências: Construção histórica e individual do conhecimento científico; }\end{array}$ & $315 \mathrm{~h}$ \\
\hline $\begin{array}{c}\text { Módulo/Semestre 3: Vida e Meio } \\
\text { Ambiente }\end{array}$ & $\begin{array}{l}\text { Ser vivo características gerais: biomoléculas e funções vitais; } \\
\text { Diversidade dos organismos: grupos de animais e plantas; } \\
\text { Fungos, bactérias e vírus; } \\
\text { Ciclos da natureza; Fotossíntese e cadeia alimentar; } \\
\text { História da vida no planeta; } \\
\text { A distribuição da vida no planeta; biomas; biodiversidade; } \\
\text { Bioenergética: transformações de energia nos seres vivos; } \\
\text { Estudo de modelos matemáticos pertinentes aos assuntos tratados neste módulo; } \\
\text { Fundamentos de Estatística Descritiva; } \\
\text { Introdução aos Estudos da Educação; }\end{array}$ & $315 \mathrm{~h}$ \\
\hline
\end{tabular}


Tabela 9. Curso "Licenciatura em Ciências": estrutura e organização (continuação).

Atividade

Tema

Carga Horária

O Ser Humano e o Meio Ambiente: Introdução à Ecologia Humana;

Do indivíduo à comunidade: Conceitos ecológicos de população, comunidade, ecossistemas e biomas;

A homeostasia e o organismo humano;

Interações do ser humano com o meio ambiente;

O Organismo Humano: grandes sistemas de integração e controle do meio interno: sistema nervoso,

Módulo/Semestre 4: Ser Humano e

sistema endócrino e sistema imunitário;

Meio Ambiente

O Ser Humano e a Ontogênese: reprodução, desenvolvimento, crescimento, manutenção,

envelhecimento e morte;

Alimentação e nutrição;

Atividade física e suas consequências sobre a saúde;

Estudo de modelos matemáticos e estatísticos vinculados a assuntos tratados neste Módulo;

Política e Organização da Educação Brasileira;

Introdução aos Estudos da Educação em Ciências;

Distribuição de doenças e de seus condicionantes em populações humanas;

A intervenção humana sobre o ambiente e suas consequências;

Fenômenos sociais universais como cultura, socialização e organização social;

Módulo/Semestre 5: Ser Humano, Saúde e Sociedade

Módulo/Semestre 6:

Trabalho Humano, Tecnologia e Sociedade

Métodos estatísticos: aplicações nas pesquisas em saúde pública, controle de

Educação em Ciências: diferentes abordagens da ciência na prática docente;

Psicologia da Educação: desenvolvimento físico, psicológico, cognitivo e social;

O ser humano e a transformação da Natureza;

Ciência, Sociedade e Tecnologia;

Apropriação e transformação de recursos minerais, animais, vegetais pela sociedade, causas e

consequências;

Perspectivas tecnológicas: engenharia genética, células tronco, nanotecnologia;

Educação em Ciências: diferentes abordagens da ciência na prática docente;

Didática: Organização do trabalho pedagógico/didático na escola; planejamento de ensino;

Metodologia do Ensino de Ciências;
Primeira fase de elaboração de um proje

Módulo/Semestre 7: Estágio e tema do projeto;

Trabalho de Conclusão de Curso 
Tabela 9. Curso "Licenciatura em Ciências": estrutura e organização (continuação).

\section{Atividade}

Módulo/Semestre 8: Estágio e

Trabalho de Conclusão de Curso

Fonte: Umekawa (2014)

\section{Tema}

Carga Horária

Metodologia do Ensino de Ciências: teorias, abordagens e concepções pedagógicas relacionadas ao

ensino de Ciências;

Segunda fase de elaboração de um projeto de ensino em ciências, estudo e discussão das bases teóricas;

elaboração do projeto de ensino; análise e discussão dos resultados; redação e apresentação do

trabalho;

Apropriação e transformação de recursos minerais, animais, vegetais pela sociedade, causas e

consequências;

Perspectivas tecnológicas: engenharia genética, células tronco, nanotecnologia;

Educação em Ciências: diferentes abordagens da ciência na prática docente;

Didática: Organização do trabalho pedagógico/didático na escola; planejamento de ensino; 
Segundo informações constantes no site do referido curso (licenciaturaciencias.usp.br) são necessárias, no mínimo, 10 horas semanais ( 2 horas por dia) para o cumprimento das tarefas online. Aos sábados são realizadas aulas presenciais (8-12h e 13h30-17h30) acerca dos temas/disciplinas previamente estabelecidos em calendário escolar; em tais momentos, educadores e docentes contam com a possibilidade de adotarem diferentes estratégias metodológicas tendo em vista as turmas e os conteúdos a serem trabalhos, exemplo: apresentação de nova temática durante aula presencial que antecede o estudo da mesma, ou revisão e síntese do objeto de interesse após a semana de estudos online. Ao final de cada um dos módulos estão previstas aulas laboratoriais (cerca de 7), nas quais são efetuadas experiências relativas aos tópicos considerados.

Por fim, no que diz respeito às atividades avaliativas - produtos/resultados de ações efetuadas no AVA (fóruns, tarefas discursivas, relatórios, exercícios) e produções derivadas de trabalhos presenciais postados após o desenvolvimento dos mesmos - estas podem ser consideradas pelo tutor válidas ou não dentro do prazo de dois dias a contar do momento da entrega. Neste processo de atribuição de "status" às atividades discentes o tutor deverá se atentar para os seguintes aspectos: a coerência das respostas emitidas frente à questão formulada e respeito aos prazos de entrega estabelecidos; sob algumas outras condições as produções podem ser consideradas inválidas, tais como: atividades em branco e conteúdos que encerrem materiais ilícitos.

\subsection{População e amostra}

De acordo com o site do curso partícipe (www.licenciaturaciencias.usp.br), todo ano são disponibilizadas 360 vagas anuais, que são distribuídas pelos 7 pólos. No pólo de Ribeirão Preto, soma-se aproximadamente 205 vagas, considerando os quatro anos de curso. Informações sobre Evasão não foram repassadas. Dessa maneira, não se pode afirmar com exatidão o número de inscritos no curso.

A amostra foi composta por 135 respondentes. Se considerarmos o total de 205 vagas, o índice de retorno foi de $65,8 \%$. Devido ao fato de que a coleta foi exclusivamente realizada online, esse é um ótimo índice retorno de respostas. A literatura aponta dificuldades com a coleta de dados online, como por exemplo, na pesquisa de Martins (2012), na qual os índices de retorno foram baixíssimos. Tal índice pode ser justificado pelo apoio constante da Docente parceira de pesquisa, que nos auxiliou no sentido de realizar lembretes semanais aos alunos, seja por meio eletrônico ou presencial. A caracterização da amostra está representada na 
tabela 10 .

Tabela 10. Características da amostra

\begin{tabular}{|c|c|c|c|c|c|}
\hline Variável & $\mathbf{F}$ & $\%$ & Variável & $\mathbf{F}$ & $\%$ \\
\hline Sexo & & & \multicolumn{3}{|c|}{ Experiência anterior no uso da internet } \\
\hline Masculino & 57 & 42,2 & Sim & 128 & 94,8 \\
\hline Feminino & 78 & $\mathbf{5 7 , 8}$ & Não & 7 & 5,2 \\
\hline Renda Mensal* & & & Escolaridade & & \\
\hline Até 1 & 18 & 13,3 & Ensino Médio Completo & 5 & 3,7 \\
\hline 2 a 3 & 56 & 41,5 & Ensino Superior Incompleto & 53 & 38,5 \\
\hline 4 a 5 & 28 & 20,7 & Ensino Superior Completo & 46 & 34,1 \\
\hline 6 ou mais & 33 & 24,4 & Pós-Graduação & 32 & 23,7 \\
\hline Estado Civil & & & Idade & & \\
\hline Solteiro & 43 & 31,9 & 20 a 29 anos & 34 & 25,2 \\
\hline Casado & 66 & 48,9 & 30 a 39 anos & 36 & 26,7 \\
\hline Amasiado & 15 & 11,1 & 40 a 49 anos & 41 & 30,4 \\
\hline Viúvo & 1 & 0,7 & 50 a 59 anos & 24 & 17,8 \\
\hline Outros & 10 & 7,4 & Média & 38 & \\
\hline Filhos & & & Desvio-Padrão & 10,16 & \\
\hline Sim & 79 & 58,5 & Moda** & 27 & \\
\hline Não & 56 & 41,5 & Mínimo & 20 & \\
\hline Profissão & & & Máximo & 59 & \\
\hline Professor(a) & 47 & 34,8 & & & \\
\hline Área Administrativa & 14 & 10,4 & & & \\
\hline Vendedor(a) & 7 & 5,2 & & & \\
\hline Autônomo(a) & 8 & 5,9 & & & \\
\hline Estudante & 22 & 16,3 & & & \\
\hline Desempregado(a) & 6 & 4,4 & & & \\
\hline Funcionário(a) Público(a) & 5 & 2,7 & & & \\
\hline Outros & 26 & 19,3 & & & \\
\hline
\end{tabular}

$\mathrm{N}=135 . \mathrm{F}=$ Frequência absoluta e \%=Porcentagem

* Renda em salários mínimos

**A amostra possui várias modas, a menor foi apresentada

As informações coletadas demonstram que a maioria dos alunos é do sexo feminino $(57,8 \%)$, casada $(48,9 \%)$ e com filhos $(58,5 \%)$. A maioria dos participantes tem entre 40 e 49 anos (30,4\%), possuindo, em média, 38 anos de idade ( $\mathrm{DP}=10,16)$, sendo 20 anos a mínima e 59 anos, a máxima. Nota-se uma população com uma faixa etária mais avançada.

Outro quesito avançado entre os participantes foi a escolaridade. A maioria dos alunos possui Ensino Superior Incompleto (38,5\%), porém, uma porcentagem bem aproximada $(34,1 \%)$ possui Ensino Superior Completo, levando a concluir que essa seria o segundo Curso de Graduação dos mesmos. A porcentagem de alunos portadores de pós-graduação também foi alta $(23,7 \%)$.

Dentre as profissões apresentadas pelos participantes, a de professor(a), foi a mais frequente $(34,8)$. Há muitos profissionais de nível técnico, que foram enquadrados na 
categoria "Outros" (19,3\%). Pode ser um leque de profissionais que gostariam de mudar de área ou apenas ampliar suas possibilidades de atuação. Algumas das profissões dessa categoria foram: Técnico em Informática, Roteirista, Técnico de Radiologia, Tecnólogo de Materiais, Metalúrgico, etc.

Por fim, a maioria afirmou ter experiência anterior no uso da internet $(94,8 \%)$.

\subsection{Instrumentos de medida}

Os instrumentos de medida empregados no estudo estão apresentados na Tabela 11.

Tabela 11. Resumo das informações sobre os instrumentos a serem utilizados na pesquisa.

\begin{tabular}{|c|c|c|c|c|c|}
\hline \multirow[t]{2}{*}{ Instrumento } & \multirow[t]{2}{*}{ Escalas obtidas } & \multirow{2}{*}{$\begin{array}{l}N^{\circ} \text { de } \\
\text { itens }\end{array}$} & \multirow[t]{2}{*}{ Alfa } & \multicolumn{2}{|c|}{$\begin{array}{c}\text { Cargas } \\
\text { fatoriais }\end{array}$} \\
\hline & & & & Min. & Max. \\
\hline \multirow{4}{*}{$\begin{array}{l}\text { Estratégias de Aprendizagem } \\
\text { (Martins, 2012) }\end{array}$} & Monitoramento da compreensão & 15 & 0,90 & 0,33 & 0,72 \\
\hline & Estratégias autorregulatórias & 4 & 0,77 & 0,46 & 0,76 \\
\hline & Busca de ajuda interpessoal & 7 & 0,86 & $-0,50$ & $-0,69$ \\
\hline & $\begin{array}{l}\text { Estratégias cognitivo- } \\
\text { comportamentais }\end{array}$ & 3 & 0,68 & 0,45 & 0,69 \\
\hline $\begin{array}{l}\text { Estilos de Aprendizagem em } \\
\text { contexto de Educação a Distância } \\
\text { em Instituição de Ensino Superior }\end{array}$ & $\begin{array}{l}\text { Instrumento construído pela autora, } \\
\text { submetido à validação estatística } \\
\text { posteriormente à aplicação. }\end{array}$ & & & & \\
\hline
\end{tabular}

As informações referentes à possibilidade de Evasão e dados sociodemográficos foram coletadas por um questionário elaborado pela autora (ANEXO A), com questões de múltipla escolha acerca dos referidos assuntos. Em relação à Evasão, foi questionado se o aluno abandonaria o curso por algum motivo, tendo como possíveis respostas o sim e o não. Para os que responderam sim, uma nova resposta era necessária, dessa vez dissertativa, explicitando o motivo dessa escolha. O instrumento de Martins (2012) foi derivado da escala proposta por Zerbini et al. (2005). A autora efetuou modificações na referida ferramenta a fim de também adaptá-la a cenários educacionais de nível superior.

Para a construção do instrumento de Estilos de Aprendizagem em contexto de EAD em IES foi adotada uma abordagem qualitativa e realizada uma revisão de literatura que auxiliasse na criação dos itens, conforme apresentado no Capítulo 3. O levantamento bibliográfico visou examinar os avanços na construção e validação de instrumentos nacionais e estrangeiros que se dedicaram a mensurar os Estilos de Aprendizagem em alunos de cursos superiores a distância. Após realizada a revisão de literatura, foi selecionado o instrumento 
Index of Learnings Styles (ILS) de Vermunt (1998), por ser um instrumento aplicado no contexto de IES em EaD com melhores índices de validade (Brant, 2014).

Este instrumento é composto por 120 itens e quatro domínios, a saber: Atividades de processamento da informação, com 27 itens e 5 escalas com $\alpha$ variando de 0,67 a 0,80 e cargas fatoriais variando de 0,27 a 0,75; Atividades de regulação da aprendizagem, com 28 itens e 5 escalas com $\alpha$ variando de 0,67 a 0,78 e cargas fatoriais variando de 0,67 a 0,82 ; Orientações de aprendizagem, 25 itens, 5 escalas com índice de confiabilidade $\alpha$ variando de 0,74 a 0,93, e cargas fatoriais variando de 0,35 a 0,72; Modelos mentais de aprendizagem, 40 itens, 5 escalas com $\alpha$ de 0,68 a 0,93 , e cargas fatoriais entre 0,24 e 0,84 . Os itens estão associados a uma escala tipo Likert de frequência de 5 pontos. O instrumento foi validado em uma Regular University (RU) em uma Open University (OU). A RU oferecia cursos de graduação presencialmente enquanto a OU oferecia cursos à distância. Tais índices se referem à validação estatística em uma $\mathrm{OU}$ e foram selecionados devido à semelhança com o objetivo do instrumento dessa pesquisa.

Por serem preferências do indivíduo, optou-se pela construção de uma escala de preferências, variando de "sempre prefiro" a "nunca prefiro", associados a uma escala Likert de 5 pontos.

A partir disso, temos uma definição diferenciada da de Vermunt (1998), a saber: "Os Estilos de Aprendizagem são um conjunto coerente de atividades de aprendizagem que os indivíduos utilizam frequentemente, de acordo com a orientação e as concepções individuais de aprendizagem. São um construto multidimensional no qual as estratégias regulatórias e as estratégias de processamento são influenciadas pela visão pessoal e pelas atitudes do participante a respeito do evento de treinamento".

Analisando as definições de atividades de Processamento da Informação (Sub escala de relacionamento e estruturação: relacionar elementos do assunto principal entre si e estruturar esses elementos em um único conjunto, que é o assunto como um todo; Sub escala de processamento crítico: formar sua própria opinião sobre os assuntos que são tratados, tirando suas próprias conclusões e sendo críticos em relação às conclusões tiradas pelos autores do materiais de estudo; Sub escala memorização e ensaio: aprender fatos, definições, listas de características, repetindo-as e decorando-as; Sub escala de análise: o assunto é estudado de forma gradual e seus elementos são estudados individualmente e separadamente, um por um.; Escala de processamento concreto: pensar em exemplos que eles conheçam de sua própria experiência enquanto estudam, e usar o que aprender no curso em suas atividades fora dos 
estudos), bem como as atividades de regulação da aprendizagem (Sub escala de autorregulação dos processos de aprendizagem e resultados: Planejar as atividades de processamento, diagnosticar a causa dos problemas que ocorrem durante a aprendizagem, inventar perguntas para testar seu progresso de aprendizagem, e também dirigir a aprendizagem para objetivos que não são apresentados a eles, mas que eles se colocam; Sub escala de autorregulação dos conteúdos de aprendizagem: consultar a literatura e fontes fora do programa; sub escala de regulação externa dos processos de aprendizagem: definir os instrumentos para sua regulação de aprendizagem através do material didático apresentado no curso ou através das informações em repassadas em aula; Sub escala de regulação externa dos resultados de aprendizagem: os alunos, para monitorar e testar seus resultados de aprendizagem, são dirigidos, em grande parte, pelo complemento didático, buscando ajuda no material didático oferecido pelos docentes, tais como auto-testes, trabalhos e perguntas; escala de falta de regulamentação: dificuldade no monitoramento para regulamentar os próprios processos de aprendizagem.), pode-se verificar que as definições são semelhantes às Estratégias de Aprendizagem definidas por Zerbini (2007): "São procedimentos utilizados pelos indivíduos durante as atividades de aprendizagem para ser bem sucedido. As estratégias variam mais do que os estilos, já que podem ter a influência das preferências gerais do indivíduo. São passíveis de treinamento”. Da mesma maneira, os itens pertencentes a esses domínios geralmente foram relacionados a Estratégias de Aprendizagem.

Portanto, foi realizada uma exclusão dos itens que segundo pesquisas recentes em TD\&E são relacionados às Estratégias de Aprendizagem, alterados alguns itens em sua redação, tornando a escala de preferência, e adicionados alguns itens que não foram contemplados por Vermunt e são parte constituinte da definição de Zerbini (2007). O cotejamento entre o instrumento e as definições supracitadas possibilitou a modificação, inclusão e exclusão de itens, tendo resultado em uma nova versão composta por 27 itens - mais adequados à aplicação em curso de ensino superior oferecido a distância (Anexo A).

A versão final do conjunto de itens de Estilos de Aprendizagem obtida na revisão bibliográfica e na análise de conteúdo foi submetida à validação semântica, onde foram identificados e corrigidos os termos e nomenclaturas do instrumento, bem como a clareza dos itens e contou com participantes semelhantes à amostra desse estudo. Posteriormente, foi submetida à validação por juízes, na qual especialistas da área analisaram a representatividade, clareza e precisão dos itens, bem como avaliam as instruções e a adequação do instrumento produzido. 
Para que os itens do instrumento fossem submetidos à validação semântica, um grupo de alunos de graduação foi orientado a realizar a leitura e julgamento de cada item elencado, avaliando-os quanto à precisão, clareza e objetividade apresentada pelos mesmos, bem como a adequação das instruções constantes na escala. Após realizarem a leitura de cada item, os participantes da validação semântica julgaram e indicaram a substituição de palavras ou acréscimo de expressões que complementassem as variáveis expressas; foram apontadas dúvidas ou incertezas que se manifestaram no momento de responder à escala devido aos aspectos dúbios de alguns itens. Todas as modificações sugeridas pelos participantes foram inseridas em um arquivo desenvolvido para este intento. As alterações propostas foram avaliadas por meio de análise e comparação com a versão do questionário aplicado e, quando consideradas alternativas mais adequadas para o aperfeiçoamento da escala, os itens sofreram a reelaboração necessária.

O conjunto final de itens relacionados aos Estilos de Aprendizagem em EAD foi submetido à validação por juízes.

Após essa validação, o instrumento estava pronto para ser aplicado e, posteriormente, prosseguir a validação estatística do mesmo.

\subsection{Considerações éticas}

O projeto de pesquisa foi submetido ao Comitê de Ética em Pesquisa FFCLRP - USP. Após a aprovação, a universidade participante foi contatada, sendo o coordenador do Pólo de Ribeirão Preto esclarecido sobre os objetivos da pesquisa e os procedimentos que seriam utilizados. Mediante sua autorização, foi possível a realização da pesquisa.

Como a pesquisa foi realizada inteiramente online, previamente ao início dos questionários, era apresentado aos participantes um Termo de Consentimento Livre e Esclarecido (ANEXO B), aprovado pelo Comitê de Ética referido, que assegurava a manutenção de sigilo e anonimato acerca de sua identidade, o caráter de sua participação voluntária, bem como solicitava a autorização do uso de suas informações no estudo. Para prosseguir com as respostas dos questionários, o participante deveria assinalar "Eu concordo". Caso ele optasse pela opção "Não concordo", uma nova tela aparecia, agradecendo e encerrando sua participação na pesquisa. 


\subsection{Procedimentos de coleta de dados}

Para cumprir com os objetivos propostos pela presente pesquisa, foram aplicados questionários a uma amostra de alunos de graduação na modalidade EAD da universidade participante. Tais questionários se propuseram a levantar o perfil sociodemográfico dos alunos, as Estratégias e os Estilos de Aprendizagem utilizados por eles durante o curso, e a possibilidade ou não da Evasão.

A coleta aconteceu nos meses de Setembro e Outubro de 2015 e foi realizada totalmente à distância, por meio da internet e um aplicativo gratuito fornecido pela Google (GoogleDocs). Tal aplicativo possibilitou a publicação dos questionários online através de um link a ser fornecido a eles. A Docente que nos auxiliou na pesquisa forneceu o link para todos os alunos via e-mail e via lembrete no ambiente virtual de aprendizagem (AVA). A cada semana, a mesma realizada novos lembretes aos alunos. A pesquisa ficou no ar por cinco semanas.

As respostas foram gravadas em um software online também do GoogleDocs, no formato de planilhas, e posteriormente foram importadas para o software de análise de dados. Somente a pesquisadora responsável teve acesso a esses dados, não sendo, portanto, de domínio público.

Dos aproximadamente 205 inscritos do curso, obteve-se um retorno de 135 respostas, o que gera um índice de retorno de aproximadamente $66 \%$. Tal índice pode ser considerado um ótimo índice, especialmente no contexto de coleta de dados a distância.

\subsection{Procedimentos de análise de dados}

Em primeiro lugar, foram realizadas análises descritivas (média, desvio-padrão, moda, mínimo e máximo) e exploratórias para investigar a exatidão da entrada dos dados, a presença de casos extremos, a distribuição de casos omissos, a distribuição de frequência das variáveis e o tamanho das amostras. Após esse momento, foram realizadas as análises diretamente relacionadas ao alcance dos objetivos desta pesquisa. A seguir, apresentam-se os procedimentos das análises feitas nas duas etapas da presente pesquisa. ${ }^{1}$

\footnotetext{
${ }^{1}$ Os procedimentos de análises de dados, bem como os autores supracitados, são retirados de Zerbini (2007), que descreve todas as etapas de maneira detalhada. Sendo assim, tal referência foi utilizada como norteadora da presente análise de dados.
} 


\subsubsection{Procedimentos de análises exploratórias das estruturas empíricas dos questionários}

Todas as análises da validação dos instrumentos foram realizadas no SPSS versão 21.0. Foram realizadas análises exploratórias para identificação de casos omissos; casos extremos univariados e multivariados, multicolinearidade, singularidade e linearidade, de acordo com as orientações de Tabachnick e Fidell (2007). Os testes de normalidade das distribuições de frequência não foram realizados, uma vez que segundo Pasquali (2004), a normalidade não é um problema grave na análise fatorial exploratória, pois essa técnica é robusta à violação desse pressuposto, suportando desvios da normalidade.

Tabachnick e Fidell (2007) orientam que, caso sejam identificados casos omissos, os mesmo podem ser tratados de três maneiras: substituí-los pela média; eliminá-los em uma ou duas variáveis, quando os mesmos são tomados aos pares (pairwise); considerar apenas os casos que contêm dados válidos em todos os indicadores/variáveis (listwise). Ao optar-se por um desses procedimentos, é importante considerar a quantidade e a aleatoriedade de dados ausentes, em função da possível identificação de subgrupos amostrais. Porém, tal análise não é necessária quando o percentual de dados omissos for inferior a 5\% dos casos. Sendo assim, ao verificar-se os casos omissos da presente pesquisa, notou-se que nenhuma variável apresentava mais do que $5 \%$ dos casos omissos e optou-se pela utilização do método pairwise.

Ainda sob a orientação de Tabachnick e Fidell (2007), todas as variáveis foram transformadas em escores $\mathrm{Z}$, visando a identificação dos casos extremos univariados. Para os autores, casos extremos univariados são definidos como respostas que destoam do conjunto de respostas em uma única variável. Foram excluídas todas as respostas cujos escores padronizados eram iguais ou superiores a 3,29 ( $\mathrm{p}<0,001$, two-tailed). Já casos extremos multivariados são definidos como valores resultantes de uma combinação anormal de escores em duas ou mais variáveis. Os mesmos foram identificados a partir da distância Mahalanobis - distância de um caso do centro do restante dos casos, quando o centro é o ponto criado pelas médias de todas as variáveis - $(\alpha=0,001)$ e, posteriormente, excluídos.

Em seguida, iniciaram-se as análises fatoriais exploratórias dos dois instrumentos, seguindo as orientações de Pasquali (2004). Algumas das orientações do autor são: a) coleta da informação através de pesquisa empírica; b) elaboração da matriz de covariância; c) análise da matriz de covariância em termos de fatorabilidade e do número de fatores; d) extração inicial dos fatores; e) rotação dos fatores para uma estrutura final; f) interpretação dos fatores; 
g) construção dos escores fatoriais para uso em análises futuras. Para elaborar a matriz de covariância, foram seguidas mais algumas orientações do autor, sendo elas:

a) Tipos de coeficientes de correlação: utilizou-se as correlações bivariadas paramétricas de Pearson, pois é o tipo mais adequado de matriz de covariâncias para análise fatorial;

b) Tamanho da amostra: considerou-se o recomendado de cerca de 10 casos para cada variável observável

c) Normalidade e Linearidade: não foi realizado teste de normalidade, pois, como dito anteriormente, não é um problema grave na análise fatorial exploratória, uma vez que a análise é robusta contra este problema e suporta desvios da normalidade. Já a linearidade afeta a análise fatorial, uma vez que as correlações consistem em medidas de relações lineares. A linearidade foi analisada através de correlações bivariadas, considerando o coeficiente de correlação produto-momento de Pearson - valores diferentes de 0 (zero) e significativos indicam a presença de uma relação linear, considerada forte quanto mais próxima de 1 (um) for o coeficiente obtido;

d) Multicolinearidade e Singularidade - as variáveis possuem multicolinearidade quando são tão correlacionadas que parecem sinônimos. A orientação para esse caso, é que uma das variáveis deve ser eliminada da análise. Já as variáveis com singularidade são redundantes, ou seja, uma variável é a combinação de duas ou mais variáveis. Para analisar a multicolinearidade e singularidade, verificou-se a existência de correlações superiores a 0,90, tal como sugerido por Pasquali (2004).

A análise da matriz de covariância em termos de fatorabilidade (verificar se de fato a matriz tem covariâncias) e do número de fatores, foi realizada de acordo com os seguintes passos:

a) Análise do tamanho das correlações - considerou-se uma correlação importante quando o valor obtido estava acima de 0,30, positivo ou negativo. Quando os valores de correlações acima de 0,30 ultrapassavam $50 \%$ dos casos, a matriz podia ser fatorizável;

b) Teste de adequação da amostra de Kaiser-Meyer-Olkin (KMO) - analisou-se as correlações parciais das variáveis. Quanto mais próximo do valor 1 for esta estatística, mais a matriz é fatorável, porque isto indica que as variáveis têm muita variância em comum.

A análise dos componentes principais (Principal Components - PC) foi realizada para obter a extração inicial dos fatores. A PC pretende reduzir o número de variáveis em componentes que expliquem a maior parte da variância original das variáveis. Para isso, analisa os componentes mais importantes e é considerada uma técnica de simplificação e 
ortogonalização apenas. Por outro lado, a análise fatorial (AF) analisa as covariâncias e possui um modelo teórico que subsidia as suas análises, ou seja, a AF assume que a covariância entre as variáveis é produto de uma causa comum entre elas: os fatores comuns. A PC preocupa-se apenas em reduzir o tamanho de uma matriz (rank reduction). Para definir o número de componentes na PC, foram utilizados os seguintes critérios:

a) Critérios convencionais - foram considerados apenas os valores próprios (eigenvalues) superiores a 1 (um); e foi analisada a distribuição visual dos valores próprios, o scree plot (os pontos que representam os componentes passam de uma inclinação acentuada para uma inclinação quase horizontal; esse ponto de mudança considera-se indicativo do número máximo de fatores a serem extraídos);

b) Critérios estatísticos (testes de significância) - através da análise paralela de Horn, foram comparados valores próprios empíricos, obtidos pela análise da PC, com valores próprios aleatórios, obtidos com o auxílio do software RanEign, em função da quantidade de variáveis e do tamanho da amostra. Os fatores são retirados da estrutura quando apresentam valor próprio empírico igual ou menor que os valores aleatórios. Segundo Laros (2004), tal análise apresenta índice de precisão de $92 \%$ de indicação correta do número de fatores, sendo o melhor método para definição de número de fatores de uma matriz de respostas a questionários;

c) Critérios de relevância do fator - foram feitas análises de interpretabilidade, importância e consistência dos fatores após a rotação dos fatores. A importância do fator é definida pela variância que consegue explicar após a rotação da matriz fatorial. O critério de Harman considera um fator irrelevante aquele que explica menos do que 3\% da variância total das variáveis. A validade do fator é expressa pelo tamanho das cargas fatoriais, ou seja, quanto maiores elas forem, mais a variável é representativa do fator. Entretanto, um fator pode ser válido, porém pode não ser consistente, por isso, também foram feitas análises de consistência dos fatores, por meio da análise de Alfa de Cronbach.

Para confirmar as estruturas fatoriais, foram realizadas análises fatoriais utilizando o método de fatoração dos eixos principais (Principal Axis Factoring - PAF). Tal método, apesar de utilizar os mesmos procedimentos da PC, substitui o valor 1 da PC por uma estimativa das comunalidades na diagonal da matriz, uma vez que a variabilidade que interessa na PAF é a variabilidade que as variáveis têm em comum, isto é, a covariância entre elas (modelo causal). A vantagem de realizar a PC antes da PAF, com todos os seus critérios, é definir os números mínimos de fatores a serem inicialmente extraídos. 
Foi utilizado o método de rotação oblíqua (direct oblimin), o qual permite que apareçam fatores ortogonais quando estes existem, e, ao mesmo tempo, não força a dependência entre os fatores, ao passo que a rotação ortogonal só permite fatores independentes. Por fim, após a extração dos fatores, verificou-se a estabilidade e interpretabilidade dos mesmos, bem como, foram produzidos escores fatoriais.

Para analisar a estabilidade, foi verificado o quanto os itens eram bons representantes do fator, pelo tamanho da carga fatorial, que é a correlação entre o item com o conjunto dos outros itens do fator (quanto mais próxima de 1 for esta carga, melhor representa o fator). Para analisar a interpretabilidade, identificou-se o traço latente que é considerado a causa do agrupamento das variáveis, por meio da análise da literatura da área. Os escores fatoriais foram produzidos pela média dos escores das variáveis originais que pertencem ao fator.

\subsubsection{Procedimentos de análise dos testes ANOVAS, Testes $t$ e Validade Convergente entre instrumentos.}

Após as análises fatoriais exploratórias, foram produzidos os escores fatoriais a partir da média das variáveis originais dos fatores. As ANOVAS e Testes $t$ foram realizadas para complementar as informações obtidas no processo de validação estatísticas das escalas utilizadas. As correlações entre os escores fatoriais dos instrumentos de Estratégias de Aprendizagem e Estilos de Aprendizagem possibilitaram a Validação Convergente dos instrumentos.

Para o cálculo da ANOVA e do Teste t, foi utilizado o mesmo banco de dados obtido após as análises exploratória, sendo observados os casos omissos; casos extremos univariados e multivariados, multicolinearidade, singularidade e linearidade. Os dados omissos foram tratados pelo método pairwise, uma vez que nenhuma variável apresentava mais do que 5\% dos casos omissos. Para identificação dos casos extremos univariados todas as variáveis foram transformadas em escores $\mathrm{Z}$ e excluídas todas as respostas cujos escores padronizados eram iguais ou superiores a 3,29 ( $\mathrm{p}<0,001$, two-tailed). Os casos extremos multivariados foram identificados a partir da distância Mahalanobis $(\alpha=0,001)$ e, posteriormente, excluídos.

Após obtidos os escores fatoriais dos instrumentos, os mesmos foram submetidos à uma correlação bivariada, sendo consideradas para análise as correlações significativas, considerando $\mathrm{p}<0,01$. Foram consideradas as correlações maiores que 0,30 . 
Os autores Morales Vallejo et al. (2003), ao discorrer a respeito da validade de instrumentos, demonstram dois tipos de estratégias complementares para provar as hipóteses elaboradas em relação ao construto estudado: a validade convergente e a validade divergente.

Ao realizar a validade convergente, serão estudadas as relações esperadas e plausíveis com outras medidas relacionadas. São possíveis dois tipos de relações nesse tipo de validação: 1 . Relações estabelecidas com variáveis medidas por outros instrumentos que intencionalmente medem o mesmo construto; 2. Relações com instrumentos que medem outros aspectos com o qual se espera que exista uma relação positiva ou negativa.

A validade divergente, também denominada validade discriminante, por sua vez, está relacionada ao grau em que uma medida não se correlaciona com outras medidas das quais se supõe que deve divergir (Sánchez \& Sarábia, 1999). Segundo Morales Vallejo et al. (2003), os dados dos instrumentos a serem correlacionados devem ser coletados simultaneamente, o que necessariamente exige um planejamento por parte do pesquisador.

Dessa maneira, no processo de validação convergente e divergente é necessário especificar as hipóteses previstas entre as variáveis envolvidas indicando: 1. O sentido que se espera da relação, seja positivo, negativo, ou ausência de relação e; 2 . A magnitude relativa esperada da relação, onde se pode comprovar a existência de relações maiores e mais claras (Silva, Macêdo \& Silva, 2013).

Para esse estudo, foram analisadas as correlações entre os fatores dos Instrumentos de Estratégias de Aprendizagem e Estilos de Aprendizagem. No caso da presente amostra, não foram encontradas correlações negativas, como será demonstrado nos resultados. Além disso, o critério 10 participantes por variável de Pasquali (2005) não foi atendido, tornando inviável a realização da análise divergente através da Análise Fatorial Exploratória. Sendo assim, considera-se que foi realizada somente a validação convergente dos instrumentos.

\subsubsection{Procedimentos de análise de conteúdo da questão dissertativa relacionada ao motivo pelo qual evadiria do curso}

Para analisar as respostas dissertativas respondidas pelos alunos que optaram pelo "Sim" na questão "Você abandonaria o curso por algum motivo?", Foram considerados os fatores do instrumento "Fatores relacionados à evasão e à persistência em EAD" de Umekawa (2014).

O Fator 1, denominado pela autora como "Suporte Tecnológico e de Tutoria”, é composto por itens que objetivam avaliar o quanto aspectos relacionados às competências demonstradas pelo tutor ao longo do curso; à acessibilidade dos materiais e o suporte institucional e social 
recebido pelo estudante; e às ferramentas virtuais de acesso dificultaram a permanência do aluno no curso. O Fator 2, denominado "Características Exógenas ao Curso", é formado por 11 itens e visa apreciar o quanto variáveis ligadas à conciliação do curso com outras atividades de estudos, profissionais e compromissos familiares; à disponibilidade de tempo; e a problemas de saúde dificultaram a persistência do estudante. O Fator 3, "Características do Aluno", é constituído por 8 itens e pretende averiguar o quanto elementos relativos às habilidades e atributos discentes (tais como administrar o tempo de estudo, elaborar planos de estudo, respeitar e cumprir prazos, perseverar frente a contratempos e experiências prévias com os recursos tecnológicos) interferiram sobre a permanência do mesmo na ação educativa. Por fim, o Fator 4, denominado "Desenho do Curso" e composto por 4 itens mede se os aspectos relativos ao planejamento instrucional (objetivos propostos, planejamento de conteúdos, sequência de conteúdos, avaliações de aprendizagem, carga horária, linguagem empregada e complexidade do curso) contribuem para a saída/permanência do aluno do evento educativo. Através da análise de conteúdo das respostas, buscou-se relacioná-las aos fatores do presente instrumento, verificando a frequência de cada fator.

Após ser apresentado todo o método utilizado nesse estudo, o próximo capítulo trata dos resultados obtidos. Os mesmos serão apresentados detalhadamente a seguir. 


\section{CAPÍTULO 5. RESULTADOS}

\section{Objetivos do capítulo 5}

O presente capítulo tem como objetivo apresentar os resultados da presente pesquisa, resultantes das análises descritivas dos Instrumentos de Estilos de Aprendizagem e Estratégias de Aprendizagem, da análise acerca da possibilidade de Evasão do curso, da construção e validação semântica, por juízes e estatística do instrumento Estilos de Aprendizagem para EAD em IES; da validação estatística do instrumento de Estratégias de Aprendizagem; da aplicação dos testes T e ANOVA; da validade convergente entre os instrumentos de Estilos de Aprendizagem e de Estratégias de Aprendizagem e da análise conceitual do construto Estilos de Aprendizagem.

\subsection{Análises descritivas}

Essa seção apresenta os resultados descritivos dos instrumentos utilizados nesta pesquisa. São discutidos o valor das médias, desvio-padrão, modas, mínimo, máximo e a concentração das respostas dadas pelos participantes. Além disso, será apresentado os dados descritivos da questão objetiva que tratava da possibilidade de Evasão dos alunos.

\subsubsection{Estratégias de Aprendizagem}

A tabela 12 apresenta os resultados descritivos dos itens do questionário de Estratégias de Aprendizagem de Martins (2012). O questionário mensura a frequência de uso de capacidades cognitivas, habilidades comportamentais, monitoramento da compreensão e controle da ansiedade e da motivação pelos alunos, para controlar os próprios processos psicológicos de aprendizagem durante o curso. São 29 itens associados a uma escala de frequência de varia de 0 (Nunca) a 10 (Sempre). Os valores máximo e mínimo foram omitidos, uma vez que todos os itens apresentaram valores iguais a dez e zero, respectivamente. 
Tabela 12. Resultados descritivos de Estratégias de Aprendizagem

\begin{tabular}{|c|c|c|c|c|c|c|c|}
\hline \multirow[t]{2}{*}{ Itens } & \multirow{2}{*}{$\begin{array}{l}\text { Casos } \\
\text { Omissos }\end{array}$} & \multirow[t]{2}{*}{ Média } & \multirow[t]{2}{*}{ Moda } & \multirow{2}{*}{$\begin{array}{l}\text { Desvio } \\
\text { Padrão }\end{array}$} & \multicolumn{3}{|c|}{$\begin{array}{l}\text { Concentração de } \\
\text { respostas }(\%)\end{array}$} \\
\hline & & & & & $0-4$ & $5-7$ & $8-10$ \\
\hline $\begin{array}{l}\text { 27. Associei os conteúdos do curso aos meus } \\
\text { conhecimentos anteriores. }\end{array}$ & 1 & 8,45 & 10 & 1,83 & 3,7 & 21,7 & 74,6 \\
\hline $\begin{array}{l}\text { 16. Busquei sites relacionados ao conteúdo do } \\
\text { curso para me ajudar a aprender. }\end{array}$ & 0 & 8,35 & 10 & 2,25 & 6,7 & 14,8 & 78,5 \\
\hline $\begin{array}{l}\text { 10. Busquei solucionar minhas dúvidas ao } \\
\text { consultar as apostilas do curso. }\end{array}$ & 0 & 8,06 & 10 & 2,2 & 7,4 & 24,5 & 68,1 \\
\hline $\begin{array}{l}\text { 15. Busquei outras fontes de pesquisa, fora da } \\
\text { internet, relacionadas ao curso para me ajudar a } \\
\text { aprender. }\end{array}$ & 2 & 7,92 & 10 & 2,72 & 12,8 & 12,8 & 74,4 \\
\hline $\begin{array}{l}\text { 9. Esforcei-me para verificar minha compreensão } \\
\text { sobre o que estava sendo ensinado. }\end{array}$ & 2 & 7,88 & 8 & 1,88 & 3,8 & 30 & 66,2 \\
\hline $\begin{array}{l}\text { 11. Busquei compreender melhor os conteúdos } \\
\text { ao estudá-los nas apostilas do curso. }\end{array}$ & 1 & 7,88 & 10 & 2,09 & 7,5 & 25,3 & 67,2 \\
\hline $\begin{array}{l}\text { 29. Identifiquei situações diárias em que eu } \\
\text { pudesse aplicar os conteúdos do curso }\end{array}$ & 0 & 7,82 & 10 & 2,08 & 5,2 & 31,1 & 63,7 \\
\hline $\begin{array}{l}\text { 26. Busquei desenvolver uma ideia global sobre } \\
\text { como os conteúdos do curso se relacionavam } \\
\text { entre si. }\end{array}$ & 2 & 7,80 & 10 & 2,09 & 8,3 & 26,3 & 65,4 \\
\hline $\begin{array}{l}\text { 25. Refleti sobre as implicações que os } \\
\text { conteúdos aprendidos poderiam ter. }\end{array}$ & 1 & 7,72 & 10 & 2,08 & 6,7 & 32,1 & 61,2 \\
\hline 21. Fiz anotações sobre o conteúdo do curso. & 2 & 7,69 & 10 & 2,63 & 9 & 28,6 & 62,4 \\
\hline $\begin{array}{l}\text { 5. Esforcei-me mais quando percebi que estava } \\
\text { perdendo a concentração. }\end{array}$ & 2 & 7,65 & 10 & 2,27 & 10,5 & 27,1 & 62,4 \\
\hline $\begin{array}{l}\text { 6. Forcei-me a manter a atenção nos estudos } \\
\text { quando me senti desinteressado. }\end{array}$ & 1 & 7,55 & 8 & 2,31 & 9 & 28,3 & 62,7 \\
\hline $\begin{array}{l}\text { 2. Repeti a mim mesmo, quando me senti } \\
\text { ansioso, que tudo sairia bem ao final do curso. } \\
\text { 28. Diferenciei, ao analisar os conteúdos do }\end{array}$ & 1 & 7,54 & 10 & 2,6 & 11,9 & 22,4 & 65,7 \\
\hline $\begin{array}{l}\text { curso, os aspectos mais importantes dos menos } \\
\text { importantes. }\end{array}$ & 0 & 7,45 & 8 & 2,35 & 8,9 & 30,4 & 60,7 \\
\hline 1. Mantive a calma quando tive dificuldades. & 1 & 7,22 & 8 & 2,32 & 11,9 & 34,4 & 53,7 \\
\hline $\begin{array}{l}\text { 7. Esforcei-me mais quando percebi que estava } \\
\text { perdendo o interesse no assunto. }\end{array}$ & 1 & 7,13 & 8 & 2,54 & 16,4 & 25,4 & 58,2 \\
\hline 22. Fiz resumos do conteúdo do curso. & 2 & 6,98 & 10 & 2,94 & 19,5 & 26,4 & 54,1 \\
\hline $\begin{array}{l}\text { 18. Revisei os conteúdos relativos aos exercícios } \\
\text { em que cometi erros. }\end{array}$ & 0 & 6,91 & 8 & 2,42 & 12,6 & 42,2 & 45,2 \\
\hline $\begin{array}{l}\text { 8. Revisei a matéria para verificar o quanto eu } \\
\text { dominava o conteúdo. }\end{array}$ & 2 & 6,83 & 8 & 2,37 & 16,5 & 38,4 & 45,1 \\
\hline $\begin{array}{l}\text { 4. Mantive a calma diante dos erros que cometi } \\
\text { ao realizar atividades do curso. }\end{array}$ & 1 & 6,81 & 10 & 2,48 & 16,4 & 38,1 & 45,5 \\
\hline $\begin{array}{l}\text { 14. Troquei mensagens com os colegas para } \\
\text { esclarecer dúvidas sobre o conteúdo do curso. }\end{array}$ & 1 & 6,77 & 10 & 3,2 & 22,4 & 22,4 & 55,2 \\
\hline $\begin{array}{l}\text { 3. Mantive a calma com a possibilidade de ter } \\
\text { um rendimento abaixo do esperado. }\end{array}$ & 2 & 6,47 & 7 & 2,48 & 21,1 & 42,8 & 36,1 \\
\hline $\begin{array}{l}\text { 24. Fiz esquemas do conteúdo do curso como } \\
\text { método para aprender. }\end{array}$ & 0 & 6,42 & 8 & 3,02 & 20,7 & 32,6 & 46,7 \\
\hline
\end{tabular}


Tabela 12. Resultados descritivos de Estratégias de Aprendizagem (continuação)

\begin{tabular}{lccccccc}
\hline \multicolumn{1}{c}{ Itens } & $\begin{array}{c}\text { Casos } \\
\text { Omissos }\end{array}$ & Média & Moda & \multicolumn{2}{c}{$\begin{array}{c}\text { Desvio } \\
\text { Padrão }\end{array}$} & \multicolumn{2}{c}{$\begin{array}{c}\text { Concentração de } \\
\text { respostas (\%) }\end{array}$} \\
\hline & & & & $\mathbf{0 - 4}$ & $\mathbf{5 - 7}$ & $\mathbf{8 - 1 0}$ \\
\hline $\begin{array}{l}\text { 12. Busquei auxílio do tutor para esclarecer } \\
\text { minhas dúvidas sobre o conteúdo. }\end{array}$ & 1 & 6,16 & 10 & 3,08 & 27,6 & 29,1 & 43,3 \\
$\begin{array}{l}\text { 23. Li o conteúdo do curso várias vezes como } \\
\text { método para aprender. }\end{array}$ & 1 & 6,10 & 7 & 2,83 & 22,4 & 44,8 & 32,8 \\
$\begin{array}{l}\text { 20. Repeti mentalmente os conteúdos do curso } \\
\text { que gostaria de aprender. }\end{array}$ & 2 & 5,76 & 8 & 2,83 & 26,3 & 42,1 & 31,6 \\
$\begin{array}{l}\text { 17. Tentei entender o conteúdo ao aplicá-lo na } \\
\text { prática, ao invés de dedicar tempo lendo ou } \\
\text { pedindo ajuda a alguém. }\end{array}$ & 1 & 5,54 & 5 & 2,79 & 32,8 & 41,1 & 26,1 \\
$\begin{array}{l}\text { 19. Aprendi conteúdos ao mentalizá-los } \\
\text { repetidamente até perceber que havia entendido. }\end{array}$ & 1 & 5,53 & 5 & 2,89 & 28,4 & 44 & 27,6 \\
$\begin{array}{l}\text { 13. Busquei auxílio de colegas nos fóruns para } \\
\text { esclarecer minhas dúvidas. }\end{array}$ & 3 & 4,87 & 0 & 3,35 & 42,4 & 29,6 & 28 \\
\hline
\end{tabular}

\section{$\mathrm{N}=135$ casos}

*0-4: pouco se comportou da maneira descrita no item; 5-7: comportou-se com frequência razoável da maneira descrita no item; 8-10: comportou-se com muita frequência da maneira descrita no item.

As estatísticas descritivas do instrumento de Estratégias de Aprendizagem demonstram que, nessa amostra, a média de uso das Estratégias de Aprendizagem descritas nos itens teve uma variação de 4,87 a 8,45. Dos 29 itens presentes no questionário, 18 apresentaram maior concentração de respostas nos pontos mais altos da escala (entre 53,7\% e 74,6\%), 5 itens concentraram a pontuação nos pontos médios (entre 41,1\% e 44,8\%), 1 obteve a concentração de respostas nos pontos mais baixos $(42,4 \%)$ e 6 mantiveram um equilíbrio nas repostas, sem grande concentração em algum ponto. A moda também apresenta valores diversificados, com pontuações de $0,5,7,8$ e 10. As modas ratificam os valores das médias, o que indica que os alunos se comportaram com muita frequência em determinados aspectos e com baixa frequência em outros, demonstrando que algumas Estratégias de Aprendizagem são muito utilizadas enquanto que outras estratégias são pouco usadas. O número de casos omissos foi extremamente baixo, representando $0,86 \%$ de 135 casos.

Os desvios padrão apresentados são altos em sua grande maioria, o que já era esperado, pois os alunos utilizam-se de diferentes Estratégias de Aprendizagem ao longo do curso. $\mathrm{Ou}$ seja, uma mesma Estratégia pode ser extremamente utilizada por um certo aluno, e praticamente não usada por outro. O padrão e frequência de uso diferenciados de Estratégias de Aprendizagem pelos alunos também podem ser observados através da discrepância nas concentrações de respostas, valores das modas e médias.

Os 16 itens que apresentaram as médias mais altas, superiores a 7 (sete) foram: $1(\mathrm{M}=7,22$ e $\mathrm{DP}=2,32), 2(\mathrm{M}=7,54$ e $\mathrm{DP}=2,60), 5(\mathrm{M}=7,65$ e $\mathrm{DP}=2,27), 6(\mathrm{M}=7,55$ e $\mathrm{DP}=2,31), 7$ 
$(\mathrm{M}=7,13$ e $\mathrm{DP}=2,54), 9(\mathrm{M}=7,88$ e $\mathrm{DP}=1,88), 10(\mathrm{M}=8,06$ e $\mathrm{DP}=2,20), 11(\mathrm{M}=7,88$ e 2,09), $15(\mathrm{M}=7,92$ e $\mathrm{DP}=2,72), 16(\mathrm{M}=8,35$ e $\mathrm{DP}=2,25), 21(\mathrm{M}=7,69$ e $\mathrm{DP}=2,63), 25(\mathrm{M}=7,72$ e $\mathrm{DP}=2,08), 26(\mathrm{M}=7,80$ e $\mathrm{DP}=2,09), 27(\mathrm{M}=8,45$ e $\mathrm{DP}=1,83), 28(\mathrm{M}=7,45$ e $\mathrm{DP}=2,35)$ e 29 $(\mathrm{M}=7,82$ e $\mathrm{DP}=2,08)$. Esse conjunto de itens contém Estratégias Cognitivas, de Controle da Emoção, Autorregulatórias e de Busca de Ajuda Interpessoal. Ou seja, possuem itens que representam os quatro fatores do instrumento de Martins (2012).

Dos 4 itens que apresentaram as médias mais baixas, ou seja, inferiores a 6 (seis), 3 deles são representantes de Estratégias Cognitivas e apenas um pertence ao fator de Ajuda Interpessoal de Martins (2012). São eles os itens 13 ( $M=4,87$ e DP=3,35), 17 ( $M=5,54$ e $\mathrm{DP}=2,79), 19(\mathrm{M}=5,53$ e $\mathrm{DP}=2,89)$ e $20(\mathrm{M}=5,76$ e $\mathrm{DP}=2,83)$.

Analisando os presentes dados descritivos, nota-se que a maior ocorrência de médias altas está presente nos itens dos fatores 1 e 4 do presente estudo, denominados de Estratégias Autorregulatórias e Estratégias Comportamentais, respectivamente. Nota-se, portanto, que essas duas Estratégias de Aprendizagem foram as mais utilizadas pela amostra.

Por outro lado, todos os itens que apresentaram médias baixas estão relacionados ao fator 3 deste estudo, denominado Estratégias Cognitivas. Esse resultado indica que os alunos fizeram pouco uso de Estratégias Cognitivas para aquisição, organização e sistematização de conhecimentos.

\subsubsection{Estilos de Aprendizagem}

A Tabela 13 apresenta os resultados descritivos dos itens do questionário de Estilos Aprendizagem desenvolvido pela autora para esse estudo (ANEXO C). Como dito anteriormente, o instrumento foi desenvolvido sob orientação dos questionários de Vermunt (1998) e Brant (2014). No momento da aplicação, o questionário, após ter passado por validação semântica e de por Juízes, possuía 27 itens (ANEXO D). Porém, o item 23 “...realizar individualmente as tarefas", não obteve suas respostas computadas pelos aplicativo utilizado (GoogleDocs). Sendo assim, o questionário aplicado continha 26 itens que pretendiam mensurar as preferências de estudo dos alunos em ações educacionais ofertadas à distância. A escala varia de 1 (Nunca Prefiro) a 5 (Sempre Prefiro). Não serão apresentados os valores mínimo e máximo, pois todos a grande maioria dos itens apresentaram os valores 1 e 5, respectivamente. Somente os itens 8,13 e 24 apresentaram valores mínimo de 2 e máximo de 5 . 


\begin{tabular}{|c|c|c|c|c|c|c|c|}
\hline \multirow[b]{2}{*}{ Itens } & \multirow{2}{*}{$\begin{array}{l}\text { Casos } \\
\text { Omissos }\end{array}$} & \multirow{2}{*}{ Média } & \multirow[b]{2}{*}{ Moda } & \multirow{2}{*}{$\begin{array}{l}\text { Desvio } \\
\text { Padrão }\end{array}$} & \multicolumn{3}{|c|}{$\begin{array}{l}\text { Concentração das } \\
\text { respostas }(\%)\end{array}$} \\
\hline & & & & & $1-2$ & 3 & $4-5$ \\
\hline 8. Que o material didático facilite meus estudos. & 1 & 4,66 & 5 & 0,67 & 2,2 & 4,5 & 93,3 \\
\hline $\begin{array}{l}\text { 20. Realizar meus estudos em lugares bem } \\
\text { iluminados. }\end{array}$ & 0 & 4,59 & 5 & 0,82 & 3,7 & 5,9 & 90,4 \\
\hline 21. Estudar em ambientes com pouco barulho. & 1 & 4,54 & 5 & 0,87 & 3 & 9,7 & 87,3 \\
\hline $\begin{array}{l}\text { 17. Adquirir conhecimentos que sejam úteis para } \\
\text { resolução de problemas práticos. }\end{array}$ & 0 & 4,38 & 5 & 0,83 & 2,2 & 13,3 & 84,4 \\
\hline $\begin{array}{l}\text { 13. Receber instruções detalhadas sobre as } \\
\text { atividades a serem realizadas no curso. }\end{array}$ & 2 & 4,32 & 5 & 0,9 & 3,8 & 18 & 78,2 \\
\hline $\begin{array}{l}\text { 3. Cursos que atendam meus interesses } \\
\text { profissionais. }\end{array}$ & 1 & 4,17 & 5 & 1,09 & 7,5 & 17,9 & 74,6 \\
\hline $\begin{array}{l}\text { 24. Cursos que auxiliem a descoberta de minhas } \\
\text { qualidades e limitações como aprendiz }\end{array}$ & 0 & 4,16 & 5 & 0,94 & 5,2 & 21,5 & 73,3 \\
\hline $\begin{array}{l}\text { 15. Que os professores/tutores expliquem } \\
\text { claramente o que é importante estudar para alcançar } \\
\text { os objetivos propostos no curso. }\end{array}$ & 1 & 4,08 & 5 & 1,05 & 9,7 & 14,9 & 75,4 \\
\hline $\begin{array}{l}\text { 14. Ser crítico em relação ao conteúdo apresentado } \\
\text { no material didático. }\end{array}$ & 2 & 4,04 & 5 & 1,03 & 9,8 & 15 & 75,2 \\
\hline 25. Ter o material impresso para ler. & 1 & 4,04 & 5 & 1,31 & 14,2 & 16,4 & 69,4 \\
\hline 9. Cursos desafiadores. & 0 & 4,01 & 5 & 1 & 8,1 & 22,2 & 69,7 \\
\hline $\begin{array}{l}\text { 1. Ser crítico em relação às discussões apresentadas } \\
\text { pelos professores/tuores }\end{array}$ & 0 & 3,93 & 5 & 1,03 & 8,1 & 28,1 & 63,8 \\
\hline 18. Cursos que me garantam um diploma/título. & 1 & 3,91 & 5 & 1,2 & 10,4 & 25,4 & 64,2 \\
\hline $\begin{array}{l}\text { 2. Estudar uma pequena quantidade de conteúdo por } \\
\text { vez. }\end{array}$ & 1 & 3,90 & 5 & 1,09 & 9,7 & 26,9 & 63,4 \\
\hline $\begin{array}{l}\text { 23. Que sejam realizadas avaliações de } \\
\text { aprendizagem para verificar meu domínio do } \\
\text { conteúdo apresentado. }\end{array}$ & 1 & 3,84 & 4 & 1,02 & 8,2 & 25,4 & 66,4 \\
\hline $\begin{array}{l}\text { 6. Que os professores/tutores ofereçam exemplos de } \\
\text { como se deve estudar. }\end{array}$ & 0 & 3,60 & 5 & 1,32 & 20 & 21,5 & 58,5 \\
\hline 5. Estudar no período da noite. & 0 & 3,56 & 5 & 1,26 & 19,3 & 28,9 & 51,8 \\
\hline $\begin{array}{l}\text { 22. Decidir sozinho o que é importante estudar para } \\
\text { alcançar os objetivos propostos no curso. }\end{array}$ & 0 & 3,49 & 3 & 1,13 & 17 & 35,6 & 47,4 \\
\hline $\begin{array}{l}\text { 16. Avaliar sozinho meu domínio sobre o conteúdo } \\
\text { apresentado. }\end{array}$ & 1 & 3,37 & 3 & 1,1 & 16,4 & 37,3 & 46,3 \\
\hline 10. Estudar juntamente com outros alunos. & 0 & 3,29 & 3 & 1,37 & 24,4 & 28,9 & 46,7 \\
\hline $\begin{array}{l}\text { 7. Fazer minhas anotações em arquivos digitais no } \\
\text { computador. }\end{array}$ & 1 & 3,16 & 5 & 1,45 & 37,3 & 17,9 & 44,8 \\
\hline $\begin{array}{l}\text { 12. Participar das atividades de interação virtual } \\
\text { (fóruns, bate-papo) para discutir os conteúdos com } \\
\text { os outros estudantes. }\end{array}$ & 1 & 2,98 & 3 & 1,29 & 33,6 & 32,1 & 34,3 \\
\hline 11. Estudar no período da manhã. & 0 & 2,82 & 3 & 1,39 & 37,8 & 31,1 & 31,1 \\
\hline 19. Estudar no período da tarde. & 3 & 2,66 & 3 & 1,22 & 38,6 & 39,4 & 22 \\
\hline $\begin{array}{l}\text { 4. Realizar uma atividade paralela enquanto estudo, } \\
\text { como ouvir música, assistir televisão, navegar na } \\
\text { internet. }\end{array}$ & 0 & 2,34 & 1 & 1,44 & 59,3 & 16,3 & 24,5 \\
\hline 8. Que o material didático facilite meus estudos. & 1 & 4,66 & 5 & 0,67 & 2,2 & 4,5 & 93,3 \\
\hline
\end{tabular}

A partir da análise das estatísticas descritivas do instrumento de Estilos de Aprendizagem pode-se afirmar que, nessa amostra, a média de uso dos Estilos de Aprendizagem descritos 
nos itens apresentou uma variação de 2,34 a 4,66. Dos 26 itens presentes no questionário, 22 apresentaram maior concentração de respostas nos pontos mais altos da escala (variando entre $48,8 \%$ e 93,3\%), nenhum item concentrou a pontuação no ponto médio, somente 1 item obteve a concentração de respostas nos pontos mais baixos (59,3\%) e 3 itens mantiveram um equilíbrio nas repostas, sem grande concentração em algum ponto. A moda também apresenta valores diversificados, com pontuações de 1, 3, 4, e 5. Os valores das médias são ratificados pelos valores das modas, indicando que os alunos preferem frequentemente determinadas atividades e raramente outras atividades. Isso significa que alguns Estilos de Aprendizagem são muito comuns entre a amostra enquanto outros Estilos são pouco comuns. O número de casos omissos foi extremamente baixo, representando apenas 0,54\% de 135 casos.

Os desvios padrão apresentados são altos em sua grande maioria, o que já era esperado, pois os alunos possuem diferenciados Estilos de Aprendizagem, uma vez que preferências podem ser totalmente alteradas de acordo com o indivíduo. Ou seja, uma mesma atividade pode ser definida como uma preferência para um aluno, enquanto outro aluno não prefira a mesma em momento algum. O padrão diferenciado de Estilos de Aprendizagem dos alunos também pode ser observado através da discrepância nas concentrações de respostas, valores das modas e médias.

Os 8 itens que apresentaram as médias mais altas, superiores a 4 (quatro) foram: 3 $(\mathrm{M}=4,17$ e $\mathrm{DP}=1,09), 8(\mathrm{M}=4,66$ e $\mathrm{DP}=0,67), 9$ (4,01 e $\mathrm{DP}=1), 17(\mathrm{M}=4,38$ e $\mathrm{DP}=0,83), 21$ $(\mathrm{M}=4,54$ e $\mathrm{DP}=0,87), 24(\mathrm{M}=4,16$ e $\mathrm{DP}=0,94), 25(\mathrm{M}=4,04$ e $\mathrm{DP}=1,31)$ e $26(\mathrm{M}=4,41$ e $\mathrm{DP}=0,97)$. Os itens tratam de Estilos de uma maneira geral: tratam desde aspectos do curso, material didático, conhecimentos práticos, preferências ambientais, entre outros. Ou seja, são preferências constantes na amostra participante desse estudo.

Em relação às médias mais baixas, 4 itens obtiveram médias inferiores a 3 (três). São eles: $4(\mathrm{M}=2,34$ e $\mathrm{DP}=1,44), 11(\mathrm{M}=2,82$ e $\mathrm{DP}=1,39), 12(\mathrm{M}=2,98$ e $\mathrm{DP}=1,29)$ e $19(\mathrm{M}=2,66$ e $\mathrm{DP}=1,22$ ). Já esses itens tratam de questões relacionadas a interação, ambiente e horário de estudo. Nota-se que os alunos dessa amostra raramente preferem estudar no período da manhã ou tarde. Tal resultado pode ser justificado pelo fato de que a grande maioria dos participantes trabalha e não possui tempo livre para estudos nesses períodos. Além disso, os alunos raramente preferem participar de atividades de interação virtual, ou realizar uma atividade paralela durante os estudos.

Analisando os presentes dados descritivos, nota-se que a maior ocorrência de médias altas está presente nos itens dos fatores 1 e 2 do presente estudo, denominados Ambiente de Estudo 
e Regulação interna, respectivamente. Nota-se, portanto, que a presente amostra apresentou, para estudar, preferências relacionadas ao ambiente em que realizam esse estudo. Além disso, os alunos demonstraram preferir que o material didático e/ou os professores/tutores auxiliem na sua orientação para os estudos.

Por outro lado, o único item que apresentou uma média baixa e que não foi descartado do instrumento foi o item 12, que pertence ao fator 3 do instrumento de Estilos de Aprendizagem deste estudo, denominado Interação Interpressoal. Ou seja, os alunos da amostra deste estudo poucas vezes preferem realizar atividades que envolvam outros alunos, preferindo estudar sozinhos.

\subsubsection{Evasão}

Uma última pergunta do questionário sociodemográfico tratou da possibilidade de Evasão dos alunos, com a questão: "Você abandonaria o curso por algum motivo"? Na questão seguinte, os alunos que responderam "Sim" puderam escrever o motivo pelo qual abandonariam. Nessa seção serão apresentados os resultados quantitativos dessa questão, e na seção 5.2, os resultados qualitativos. A tabela 14 detalha esses resultados.

Tabela 14. Resultados descritivos sobre a possibilidade de Evasão

\begin{tabular}{lll}
\hline $\begin{array}{l}\text { Você abandonaria o } \\
\text { curso por algum } \\
\text { motivo? }\end{array}$ & Frequência & $\begin{array}{l}\text { Porcentagem } \\
\text { válida }\end{array}$ \\
\hline Sim & 44 & 32,6 \\
Não & 91 & 67,4 \\
Total & 135 & 100,0 \\
\hline
\end{tabular}

Nota-se, portanto, que de 135 casos, 44 abandonariam o curso por algum motivo, representando $32,6 \%$ da amostra. Os motivos pelos quais o participante abandonaria o curso foram investigados e serão apresentados na seção seguinte.

\subsection{Análise de conteúdo: Motivos pelos quais o aluno abandonaria o curso}

A presente seção apresenta os resultados advindos da análise de conteúdo realizada na questão dissertativa respondida pelos participantes que afirmaram que abandonariam o curso por algum motivo. Foi solicitado a eles que escrevessem a respeito desses motivos.

Foram um total de 44 respostas, como demonstrado na seção anterior. Todas as respostas foram lidas e organizadas segundo as categorias denominadas por Umekawa (2014), sendo elas: Suporte Tecnológico, Características Exógenas, Características do Aluno e 
Desenho do Curso. A definição de cada uma dessas categorias, que são fatores do instrumento “Fatores relacionados à evasão e à persistência em EAD”, está descrita na seção 4.8.3.

A Tabela 15 apresenta a distribuição das respostas em relação aos fatores:

Tabela 15. Distribuição dos motivos pelos quais os alunos evadiriam o curso.

\begin{tabular}{lcc}
\hline \multicolumn{1}{c}{ Motivos pelo qual evadiria do curso* } & N & Porcentagem** \\
\hline Suporte Tecnológico & 0 & 0 \\
Características Exógenas & 26 & $59,13 \%$ \\
Características do Aluno & 2 & $4,52 \%$ \\
Desenho do Curso & 16 & $36,35 \%$ \\
\hline Total & $\mathbf{4 4}$ & $\mathbf{1 0 0 \%}$ \\
\hline *Baseado nas principais categorias encontradas por Umekawa (2014) que levam a evasão &
\end{tabular}

A partir da tabela 15, pode-se concluir que em sua maioria os principais motivos pelos quais os participantes da presente pesquisa abandonariam o curso estão relacionados a Características Exógenas ao curso, representando 59,13\% das repostas. Em segundo lugar aparecem questões relacionadas ao Desenho do Curso, responsável por 36,35\% das possíveis evasões do curso. As Características do Aluno não tiveram muita influência nessa amostra, com apenas 4,52\% de representatividade. O Suporte Tecnológico, por sua vez, não obteve resposta alguma que o representasse nessa amostra. Tais dados se contrapõem com os achados de Umekawa (2014), que demonstram que o Suporte Tecnológico é o fator mais influente, explicando 29,34\% da variância do instrumento. Na sequência aparecem os Fatores Exógenos (9,36\% de variância explicada), Características do Aluno (5,55\% de variância explicada) e por fim o Desenho do Curso (4,75\% de variância explicada).

Em relação às Características Exógenas, os respondentes da presente pesquisa apresentaram motivos relacionados a problemas familiares (7 respostas $-15,9 \%)$, problemas de saúde (9 respostas $-20,45 \%)$ e falta de tempo (10 respostas - 22,78\%). Abaixo alguns exemplos de respostas do fator:

"Minha filha tem necessidades especiais e eu abandonaria o curso se não tivesse quem cuidasse dela para que eu pudesse frequentar as aulas". - Problemas Familiares "Se tiver que escolher entre o trabalho e o curso, por conta de ser pai de família, teria que escolher o trabalho". - Falta de tempo 
"Na verdade, já abandonei uma vez e estou voltando agora, eu saí por conta da minha gravidez que foi de risco e para cuidar do meu bebê que nasceu prematuro e com condição de saúde frágil’". - Problemas de saúde

As características do Aluno apresentadas pelos participantes estão relacionadas à desmotivação, dificuldade de se adaptar ao formato da EAD, entre outras. Segue exemplo:

"Por não conseguir acompanhar alguma disciplina que exige uma dedicação maior, como disciplinas voltadas para exatas que particularmente tenho dificuldade”. - Dificuldade em determinada disciplina

Por fim, o Desenho do Curso foi discutido no sentido de qualidade de ensino, o formato com somente uma aula presencial por semana, etc. Alguns participantes afirmaram que se a atual estrutura se modificar eles deixariam o curso. Já outros participantes reivindicaram mudanças no desenho atual, e discutiram a possibilidade de evadir caso não houvessem modificações/melhorias. Abaixo alguns exemplos:

"Por motivo de força maior, ou por uma queda considerável na qualidade do curso". Abandono caso o curso sofresse uma redução de qualidade

“Já pensei várias vezes em abandonar, sinceramente não me agradou muito curso EAD na USP, sinto que apenas estamos utilizando uma sala de aula para serem ministradas as aulas presenciais aos sábados, até agora não tivemos aulas presenciais com professores titulares USP, as aulas de laboratório são mal ministradas (em sala de aula) e quando termina a aula nem conseguimos compreender corretamente o que foi realizado". - Abandono caso o curso não passe por melhorias/alterações no desenho.

Nota-se, portanto, que o aluno pode evadir o curso por variados motivos, porém, todos os motivos descritos de maneira dissertativa se encaixam nos fatores denominados por Umekawa (2014), por mais que os fatores de destaque nesse estudo foram diferentes dos que se apresentaram com maior frequência no estudo da autora. Uma das causas pode ser o fato de ser uma outra amostra, com características pessoais diferenciadas, uma vez que o contexto é o mesmo.

Na próxima seção, serão apresentados os resultados da validação semântica e por juízes do instrumento de Estilos de Aprendizagem. 


\subsection{Instrumento de Estilos de Aprendizagem: Validação Semântica e por Juízes}

São apresentados nessa seção, os resultados advindos da Validação Semântica e por Juízes do instrumento de Estilos de Aprendizagem. Todos os itens, de alguma forma, sofreram alterações. Nesse trabalho, serão demonstradas apenas as discussões mais relevantes, que não se tratavam apenas de questões de escrita e semântica. Tais dados estão sistematizados na Tabela 16. Para facilitar a apresentação dos resultados, os itens serão agrupados de acordo com o tema que abordam.

Tabela 16. Validação semântica e por juízes dos itens do instrumento de Estilos de Aprendizagem

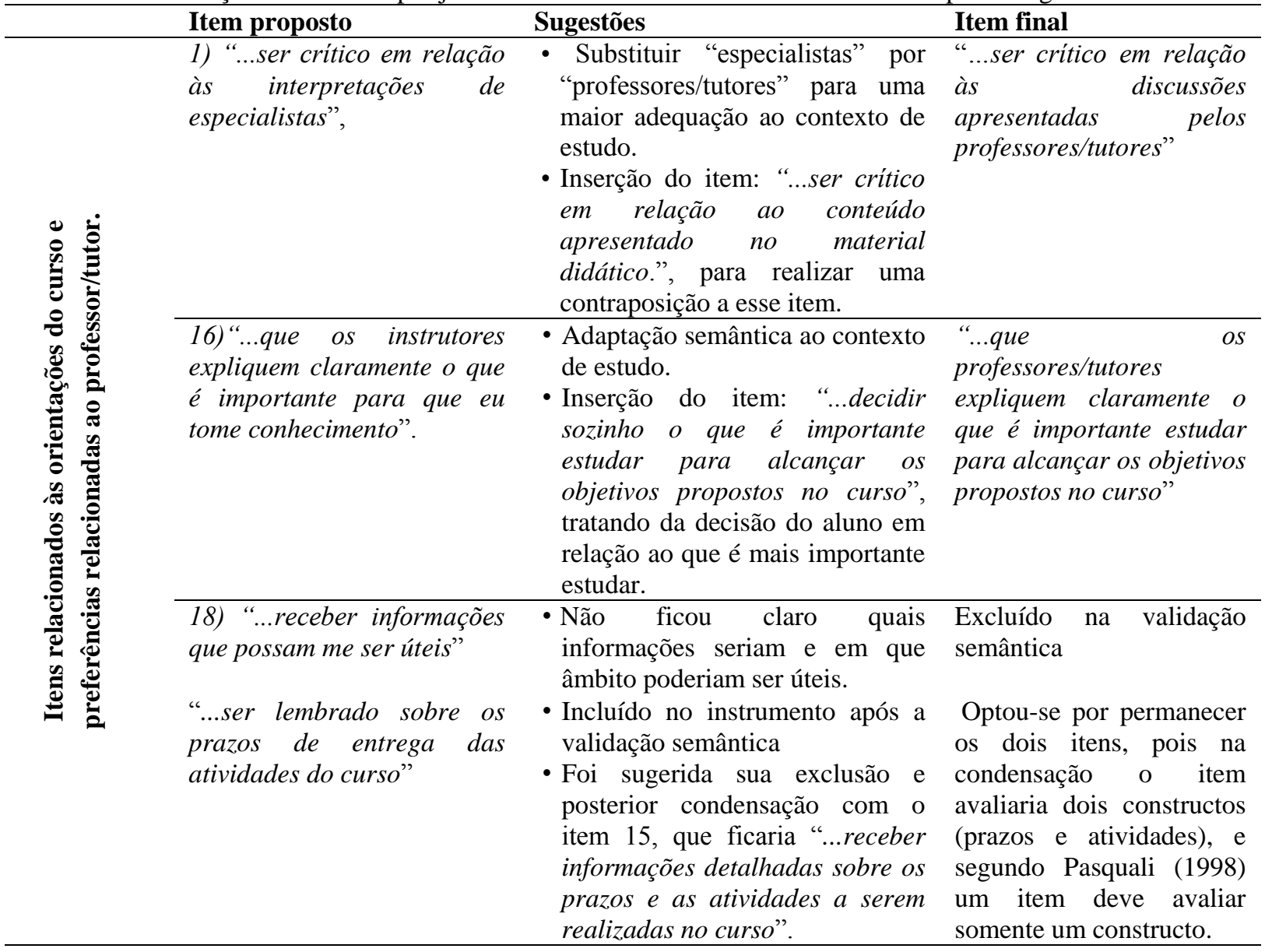


Tabela 16. Validação semântica e por juízes dos itens do instrumento de Estilos de Aprendizagem (continuação)

\begin{tabular}{|c|c|c|c|}
\hline & Item proposto & Sugestões & Item final \\
\hline \multirow{4}{*}{ 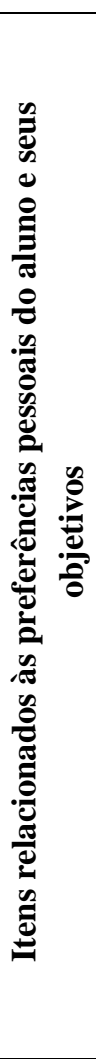 } & $\begin{array}{l}\text { 17) “...que tenham testes } \\
\text { para verificar se eu dominei } \\
\text { todo o assunto" }\end{array}$ & $\begin{array}{l}\text { - Melhoras na escrita para obter } \\
\text { uma maior clareza do item. } \\
\text { - Foi sugerido um item que } \\
\text { apresentasse uma contraposição, } \\
\text { sendo elaborado o enunciado: } \\
\text { "...avaliar sozinho meu domínio } \\
\text { do conteúdo apresentado" }\end{array}$ & $\begin{array}{lr}\text { "...que sejam realizadas } \\
\text { avaliações } & \text { de } \\
\text { aprendizagem } & \text { para } \\
\text { verificar meu domínio do } \\
\text { conteúdo apresentado". }\end{array}$ \\
\hline & $\begin{array}{l}\text { "estudar no período da } \\
\text { noite", "estudar no período } \\
\text { da manhã" e "estudar no } \\
\text { período da tarde" }\end{array}$ & $\begin{array}{l}\text { - Incluídos após a validação } \\
\text { semântica por serem preferências } \\
\text { importantes a serem medidas e } \\
\text { foi notada sua ausência. } \\
\text { - Na validação por juízes, foi } \\
\text { questionado sobre sua } \\
\text { permanência. }\end{array}$ & $\begin{array}{l}\text { Por serem três itens e pelo } \\
\text { fato que Zerbini (2007) } \\
\text { afirma sua importância } \\
\text { como um estilo de } \\
\text { aprendizagem, optou-se } \\
\text { pela permanência dos } \\
\text { mesmos. }\end{array}$ \\
\hline & $\begin{array}{l}\text { "...estabelecer metas de } \\
\text { desempenho no curso" }\end{array}$ & $\begin{array}{l}\text { - Incluído após a validação } \\
\text { semântica por ser considerado } \\
\text { uma preferência do aluno por } \\
\text { Brant (2014), foi questionado } \\
\text { sobre sua necessidade. }\end{array}$ & $\begin{array}{l}\text { O item foi excluído por } \\
\text { não ter sido encontra } \\
\text { nenhuma literatura que o } \\
\text { justificasse. }\end{array}$ \\
\hline & $\begin{array}{l}\text { "...tentar aprender sozinho } \\
\text { mesmo quando acho o } \\
\text { conteúdo difícil" }\end{array}$ & $\begin{array}{l}\text { - Incluído após } \quad \text { validação } \\
\text { semântica por ser considerado } \\
\text { uma preferência do aluno. }\end{array}$ & 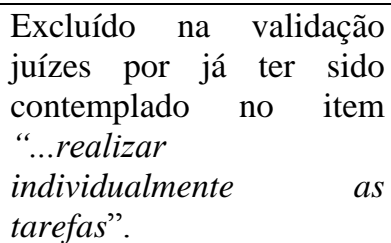 \\
\hline \multirow{4}{*}{ 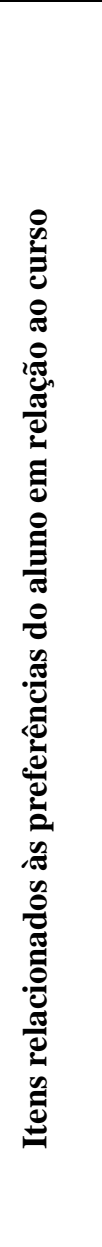 } & $\begin{array}{l}\text { 4) “...fazer cursos que me } \\
\text { enriqueçam } \\
\text { financeiramente" }\end{array}$ & $\begin{array}{l}\text { - Questionado acerca da } \\
\text { impossibilidade de garantir } \\
\text { retorno financeiro após a } \\
\text { finalização do curso }\end{array}$ & Item excluído. \\
\hline & $\begin{array}{l}\text { 5) “...cursos que sejam um } \\
\text { passatempo para mim" } \\
\text { 6) "...fazer qualquer curso, } \\
\text { pois gosto de estudar" } \\
\text { 12) "...cursos que sejam } \\
\text { adequados às minhas } \\
\text { capacidades de estudo" }\end{array}$ & - $\quad$ Falta de objetividade & Itens eliminados. \\
\hline & $\begin{array}{l}\text { 7) “... cursos que me } \\
\text { garantem um diploma" }\end{array}$ & $\begin{array}{l}\text { - Questionado acerca da redução } \\
\text { do ensino superior à obtenção } \\
\text { de um diploma, ignorando a } \\
\text { qualificação profissional, }\end{array}$ & $\begin{array}{l}\text { O item foi mantido devido } \\
\text { ao fato que atualmente o } \\
\text { diploma é muito } \\
\text { valorizado no mercado de } \\
\text { trabalho, fornecendo um } \\
\text { maior número de } \\
\text { oportunidades para os que } \\
\text { o possuem. Sendo assim, } \\
\text { foi realizada somente uma } \\
\text { alteração semântica: “... } \\
\text { cursos que me garantem } \\
\text { um diploma/título". }\end{array}$ \\
\hline & $\begin{array}{l}\text { 10) “...cursos que me } \\
\text { possibilitem } \\
\text { minhas próprias } \\
\text { e limitações" }\end{array}$ & $\begin{array}{ll} & \text { Foi } \quad \text { julgado } \\
\text { desnecessário. }\end{array}$ & $\begin{array}{l}\text { O item foi mantido para } \\
\text { medir o interesse do aluno } \\
\text { em seu autoconhecimento } \\
\text { durante o curso, ficando: } \\
\text { "...cursos que auxiliem a } \\
\text { descoberta de minhas } \\
\text { qualidades e limitações } \\
\text { como aprendiz"," }\end{array}$ \\
\hline
\end{tabular}


Tabela 16. Validação semântica e por juízes dos itens do instrumento de Estilos de Aprendizagem (continuação)

\begin{tabular}{|c|c|c|c|}
\hline & Item proposto & Sugestões & Item final \\
\hline 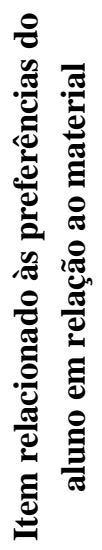 & $\begin{array}{l}\text { "...ler o material didático na } \\
\text { tela do computador" e "ter o } \\
\text { material impresso para ler e } \\
\text { fazer anotações" }\end{array}$ & $\begin{array}{l}\text { - Incluídos após a validação } \\
\text { semântica por serem } \\
\text { considerados preferências dos } \\
\text { alunos. } \\
\text { - Foram questionados na } \\
\text { validação por juízes sob o } \\
\text { argumento que um poderia } \\
\text { eliminar o outro. }\end{array}$ & $\begin{array}{l}\text { Optou-se por manter os } \\
\text { dois itens, porém, foram } \\
\text { reestruturados visando a } \\
\text { avaliação apenas de um } \\
\text { constructo em cada, } \\
\text { ficando: "...fazer minhas } \\
\text { anotações em arquivos } \\
\text { digitais no computador" e } \\
\text { "...ter o material impresso } \\
\text { para ler". }\end{array}$ \\
\hline
\end{tabular}

A frase que orienta o preenchimento do instrumento, antes colocada como "para estudar em cursos de ensino superior à distância, eu prefiro..." não recebeu crítica alguma na validação semântica, porém, na validação por juízes, foi sugerido que se retirasse o "ensino superior" pois toda a amostra será composta por estudantes desse grau de escolaridade, além de diminuir a frase e torná-la mais dinâmica para a leitura e compreensão. Ficando, portanto, "para estudar em cursos à distância, eu prefiro...".

As alterações propostas no processo de validação semântica e por juízes, possibilitaram o aprimoramento e a adaptação da escala de medida em questão, que ficou com 27 itens.

Na próxima seção, são demonstrados os resultados das análises fatoriais exploratórias dos instrumentos utilizados no presente estudo.

\subsection{Análises exploratórias fatoriais das estruturas empíricas dos questionários - evidências de validade}

A presente seção demonstra os resultados das análises fatoriais exploratórias das estruturas empíricas dos questionários de Estilos de Aprendizagem e Estratégias de Aprendizagem Tais análises se relacionam ao alcance dos objetivos específicos dessa pesquisa, relacionados à verificação de evidências de validade dos instrumentos de medida em contexto de ações educacionais ofertadas a distância. 


\subsubsection{Estilos de Aprendizagem}

Antes de iniciar a explanação acerca dos resultados das análises exploratórias do instrumento de Estilos de Aprendizagem, é necessário descrever o percurso que levou a esses resultados. Em um primeiro momento, foram realizadas todas as análises necessárias (linearidade, multicolinearidade, casos omissos, casos extremos e $P C$ ). Após realizar a análise paralela, obteve-se 4 fatores e realizou-se a $P A F$. No momento do cálculo da consistência interna $(\alpha)$, um dos fatores obteve um valor negativo nessa variável. O Alfa de Cronbach deve ser interpretado no intervalo entre 0 e 1, onde os valores negativos do alfa devem ser considerados como escalas sem confiança (ou seja, zero) (Nichols, 1999). Considerando isso, realizou-se novamente a $P A F$ com três e dois fatores, sempre com o mesmo problema no momento de verificação da consistência interna. Uma observação importante é que o instrumento era fatorizável, uma vez que o índice de KMO estava acima de 0,70. Além dos valores negativos do Alfa, muitos itens possuíam cargas fatoriais e comunalidades extremamente baixas. Sendo assim, fez-se necessário a revisão dos itens, pois os cálculos estavam indicando um possível erro de medida. Foi realizada, então, a revisão dos itens, bem como a análise conceitual do construto Estilos de Aprendizagem, como descrito anteriormente na seção 5.2. Feito isso, foram eliminados os itens que não estavam contemplados na definição de Estilos de Aprendizagem, ou que ainda estavam contemplados em outras definições, como por exemplo Estratégias de Aprendizagem.

A revisão do instrumento resultou num total de 13 itens. Porém, mais uma vez obtevese problemas nas análises exploratórias. Os itens 5) “...estudar no período da noite”, 11) “...estudar no período da manhã” e 19) “...estudar no período da tarde” estavam se agrupando e formando um fator, e independente dos rearranjos que pudessem serem feitos (retirada de um dos três itens, visto que dois não poderiam ser retirados simultaneamente, uma vez que não existe fator de um único item), o valor do Alfa desse fator se apresentava negativo. Buscou-se então, literatura que justificasse a inclusão dessas preferências como um Estilo de Aprendizagem, e foi encontrado apenas em Zerbini (2007). Por questões estatísticas, foi optado pela retirada dos três itens. Em uma futura pesquisa, aconselha-se a inserção dos mesmos novamente, pois pode ser uma característica dessa amostra não possuir preferências em relação ao horário de estudo, visto que a grande maioria trabalha e não tem opções de horário para realizar as atividades acadêmicas, dispondo somente do tempo no qual não está no emprego. Sendo assim, o questionário final ficou com 10 itens, sendo eles: 4, 10, 12, 13, 
15, 20, 21, 23, 25 e 26. Feitas todas essas considerações, serão apresentados aqui os resultados encontrados após as revisões e releituras do instrumento.

O questionário de Estilos de Aprendizagem apresentou 135 casos válidos e entre 0 e 1 um caso omisso nos seus 10 itens, com exceção do item 13 que apresentou 2 casos omissos. Dadas as recomendações de Tabachnick e Fidell (2007), quando o total de casos omissos não ultrapassa 5\% dos dados, não é preciso realizar nenhuma análise ou alteração dos dados. As respostas apresentaram 8 casos extremos univariados, distribuídos entre 3 dos 10 itens, cerca de 2 ou 3 por item. Por ser também um número muito baixo, optou-se por mantê-los. Não foram identificados casos extremos multivariados.

A matriz de covariância foi elaborada e analisada, o que possibilitou a verificação de que não houve relacionamentos lineares entre as variáveis (linearidade), nem a presença de singularidade e multicolinearidade. Em relação a fatorabilidade, o tamanho das correlações e a adequação da amostra foram analisados. Foram encontrados valores de correlação superiores a 0,30 em mais de 50\% dos casos, indicando que uma matriz provavelmente fatorizável. O teste de KMO também foi realizado e obteve-se um valor de 0,70, considerado um bom índice de adequação da amostra.

A extração inicial de fatores foi feita mediante análise dos componentes principais. Foi realizado o tratamento pairwise para os casos omissos. A análise dos componentes principais sugeriu uma estrutura empírica com 3 componentes, que explicam, em conjunto, $52,02 \%$ da variância total das respostas dos participantes aos itens do questionário. Foi seguido o critério dos eigenvalues (valores próprios) dos fatores maiores ou iguais a 1 (um). Considerando a importância de cada fator, cada um deles deveria explicar no mínimo 3\% da variância total. Dessa maneira, chegou-se ao valor máximo de 3 fatores a serem extraídos. Ao realizar a análise do scree plot, foi verificada a existência de 3 a 4 fatores, como pode ser observado na figura 8 . 


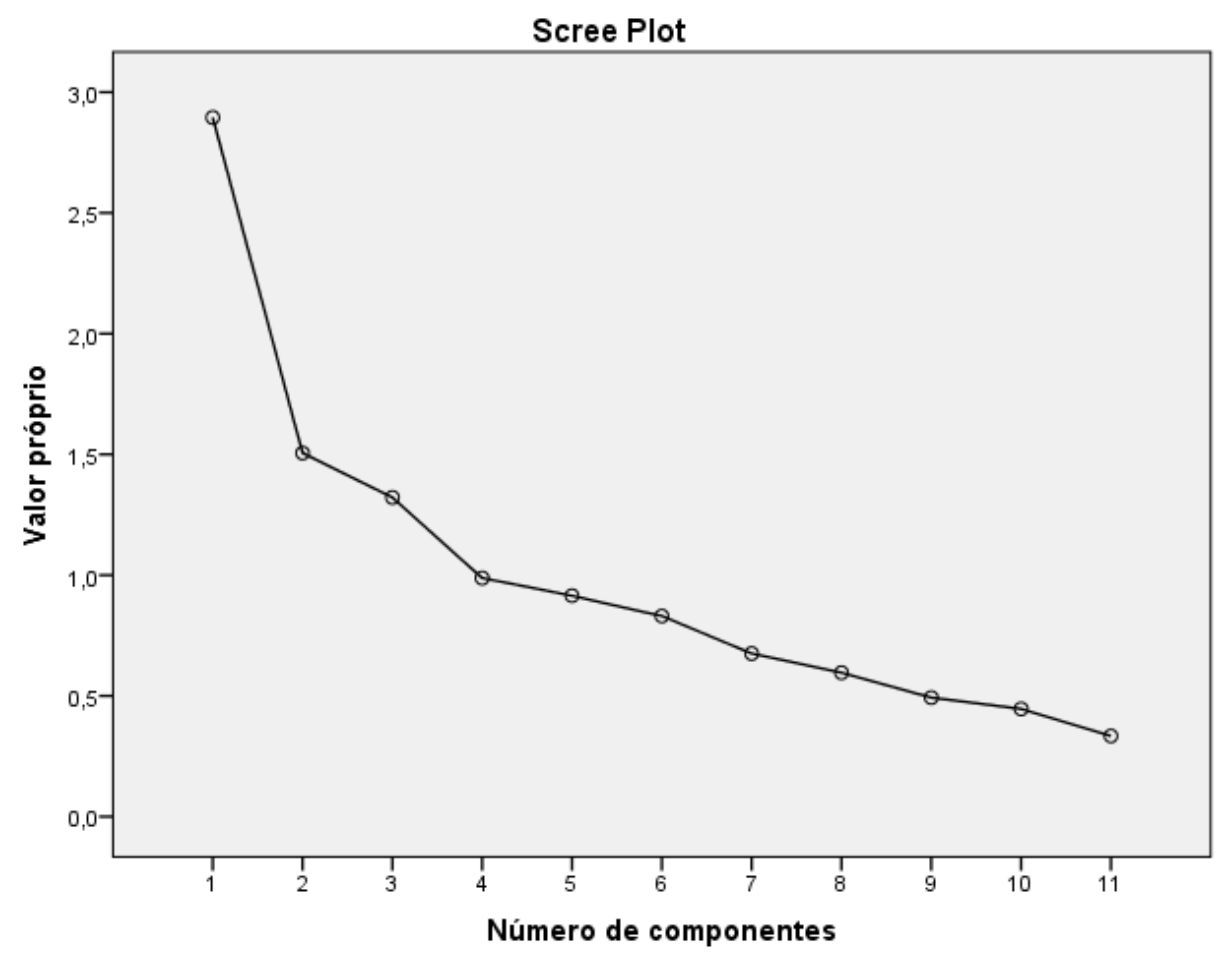

Figura 8: Distribuição dos valores próprios (scree plot) da escala de Estilos de Aprendizagem.

A análise paralela de Horn, por sua vez, apontou 3 fatores para este instrumento. Como demonstrado na tabela 17, apenas os fatores com valores empíricos maiores ou iguais aos valores aleatórios são mantidos na estrutura.

Tabela 17. Valores próprios empíricos e aleatórios dos primeiros cinco componentes de Estratégias de Aprendizagem

\begin{tabular}{lrrrrr}
\hline \multirow{2}{*}{$\begin{array}{c}\text { Valores } \\
\text { próprios }\end{array}$} & $\mathbf{1}$ & $\mathbf{2}$ & $\mathbf{3}$ & 4 & 5 \\
\hline Empírico & $\mathbf{2 , 8 9}$ & $\mathbf{1 , 5 0}$ & $\mathbf{1 , 3 2}$ & 0,98 & 0,91 \\
Aleatório & $\mathbf{1 , 9 8}$ & $\mathbf{1 , 8 3}$ & $\mathbf{1 , 7 2}$ & 1,62 & 1,53 \\
\hline
\end{tabular}

$\mathrm{N}^{\mathrm{o}}$ de itens: $10 ; \mathrm{n}=135$

A tabela 17 demonstra que os três primeiros fatores explicam maior variância do que os fatores correspondentes nos dados aleatórios. Sendo assim, a partir da análise paralela, foi possível confirmar uma estrutura com 3 fatores.

Para confirmar de maneira definitiva a estrutura fatorial do instrumento, foi realizada a $P A F$, com método de rotação oblíqua e tratamento pairwise para casos omissos. Decidiu-se incluir na escala apenas os itens com cargas fatoriais iguais ou superiores a 0,30. Tal análise permitiu a extração de 3 fatores que explicam, respectivamente, $27,41 \%, 14,13 \%$ e 12,94\% da variância total das respostas aos itens do instrumento. Somados explicam, portanto, 54,50\% 
da variância total. Após toda a revisão de literatura, a maneira pela qual os itens se agruparam e formaram fatores fez sentido teórico.

A tabela 18 apresenta a estrutura empírica da escala, as cargas fatoriais, as comunalidades $\left(h^{2}\right)$ dos itens, as médias e desvios-padrão, os índices de consistência interna, os valores próprios e percentuais de variância explicada de cada fator.

Tabela 18. Estrutura empírica da Escala de Estilos de Aprendizagem.

\begin{tabular}{|c|c|c|c|c|c|c|}
\hline \multirow{2}{*}{ Descrição dos itens } & \multicolumn{3}{|c|}{ Cargas fatoriais } & \multirow{2}{*}{$\mathbf{h}^{2}$} & \multirow{2}{*}{$\mathbf{X}$} & \multirow{2}{*}{ DP } \\
\hline & 1 & 2 & 3 & & & \\
\hline $\begin{array}{l}\text { 4. Realizar uma atividade paralela enquanto } \\
\text { estudo, como ouvir música, assistir televisão, } \\
\text { navegar na internet. }\end{array}$ & & & & 0,16 & 2,34 & 1,44 \\
\hline 10. Estudar juntamente com outros alunos. & & & 0,84 & 0,72 & 3,29 & 1,37 \\
\hline $\begin{array}{l}\text { 12. Participar das atividades de interação virtual } \\
\text { (fóruns, bate-papo) para discutir os conteúdos com } \\
\text { os outros estudantes. }\end{array}$ & & & 0,31 & 0,12 & 2,98 & 1,29 \\
\hline $\begin{array}{l}\text { 13. Receber instruções detalhadas sobre as } \\
\text { atividades a serem realizadas no curso. }\end{array}$ & & 0,39 & & 0,29 & 4,32 & 0,90 \\
\hline $\begin{array}{l}\text { 15. Que os professores/tutores expliquem } \\
\text { claramente o que é importante estudar para } \\
\text { alcançar os objetivos propostos no curso. }\end{array}$ & & 0,48 & & 0,38 & 4,08 & 1,05 \\
\hline $\begin{array}{l}\text { 20. Realizar meus estudos em lugares bem } \\
\text { iluminados. }\end{array}$ & 0,61 & & & 0,49 & 4,59 & 0,82 \\
\hline 21. Estudar em ambientes com pouco barulho. & 0,86 & & & 0,81 & 4,54 & 0,87 \\
\hline $\begin{array}{l}\text { 23. Que sejam realizadas avaliações de } \\
\text { aprendizagem para verificar meu domínio do } \\
\text { conteúdo apresentado. }\end{array}$ & & & & 0,09 & 3,84 & 1,02 \\
\hline 25. Ter o material impresso para ler. & & 0,44 & & 0,24 & 4,04 & 1,31 \\
\hline $\begin{array}{l}\text { 26. Ser lembrado sobre os prazos de entrega das } \\
\text { atividades do curso. }\end{array}$ & & 0,85 & & 0,70 & 4,41 & 0,97 \\
\hline $\mathbf{N}$ & 134 & 131 & 134 & & & \\
\hline Eigenvalue (valor próprio) & 2,74 & 1,41 & 1,29 & & & \\
\hline \% da variância explicada & 27,41 & 14,13 & 12,94 & & & \\
\hline $\mathbf{N}^{0}$ de itens & 2 & 4 & 2 & & & \\
\hline Alfa $(\alpha)$ & 0,76 & 0,63 & 0,40 & & & \\
\hline
\end{tabular}

O instrumento de Estilos de Aprendizagem (ANEXO E) possui 10 itens e é formado por 3 fatores que foram chamados de: Fator 1 "Ambiente de Estudo", Fator 2 "Regulação Externa" e Fator 3 "Interação Interpessoal”.

O item 23 "Que sejam realizadas avaliações de aprendizagem para verificar meu domínio do conteúdo apresentado" não permaneceu na estrutura por não possuir carga fatorial igual ou maior que 0,30, positiva ou negativa. Tal item pertence ao fator "Regulação Externa da Aprendizagem” de Brant (2014). Um possível motivo pelo qual o item não permaneceu no 
questionário nessa amostra é que a aplicação de avaliações não é uma preferência, pois ela ocorrerá inevitavelmente.

O item 4 "Realizar uma atividade paralela enquanto estudo, como ouvir música, assistir televisão, navegar na internet" inicialmente foi incluso no fator 1, denominado "Ambiente de Estudo”. Porém, ao realizar o cálculo de confiabilidade, o valor do Alfa apresentou um valor negativo, e foi indicado que o mesmo teria seu valor alterado caso esse item fosse retirado do fator. Sendo assim, optou-se por sua exclusão do instrumento.

O Fator 1, "Ambiente de Estudo", apresenta um total de 2 itens e possui um bom índice de consistência interna $(\alpha=0,76)$, com cargas fatoriais variando entre 0,61 e 0,86 . Os dois itens pertencentes a esse fator tratam de questões relativas ao ambiente no qual o estudo está sendo realizado, e as preferências do aluno em relação a esse contexto. São confirmados pela literatura em Zerbini (2007), que afirma que os Estilos de Aprendizagem também envolvem preferências relativas ao contexto de estudo do aluno.

O Fator 2, "Regulação Externa", apresenta um total de 4 itens e possui um moderado índice de consistência interna $(\alpha=0,63)$, com cargas fatoriais variando entre 0,39 e 0,85 . Todos os itens pertencentes a esse fator foram escritos baseado no fator "Regulação Externa da Aprendizagem" de Brant (2014), que descreve preferências do aluno em ter sua aprendizagem regulada por fatores externos a ele, como por exemplo o material didático e/ou os professores/tutores.

O Fator 3, "Interação Interpessoal”, é composto por 2 itens e apresenta um baixo índice de consistência interna $(\alpha=0,40)$, com cargas fatoriais variando entre 0,31 e 0,84 . Os itens desse fator remetem à preferência do aluno em estudar e/ou realizar as atividades do curso sozinho ou com os demais alunos. Tal preferência é citada por Vermunt (1998), Zerbini (2007) e Brant (2014).

\subsubsection{Estratégias de Aprendizagem}

O questionário de Estratégias de Aprendizagem apresenta 135 casos válidos e entre 0 1 um caso omisso nos seus 29 itens. Dada as recomendações de Tabachnick e Fidell (2007), quando o total de casos omissos não ultrapassa 5\% dos dados, não é preciso realizar nenhuma análise ou alteração dos dados. Dessa maneira, optou-se pelo tratamento de dados por pairwise. As respostas apresentaram 13 casos extremos univariados, distribuídos entre 9 dos 29 itens, cerca de 1 ou 2 por item. Por ser também um número muito baixo, optou-se por mantê-los. Não foram identificados casos extremos multivariados. 
A matriz de covariância foi elaborada e analisada, o que possibilitou a verificação de que não houve relacionamentos lineares entre as variáveis (linearidade), nem a presença de singularidade e multicolinearidade. Em relação a fatorabilidade, o tamanho das correlações e a adequação da amostra foram analisados. Sendo assim, foram encontrados valores de correlação superiores a 0,30 em mais de $50 \%$ dos casos, indicando que a matriz provavelmente fatorizável. O teste de KMO também foi realizado e obteve-se um valor de 0,80, considerado um excelente índice de adequação da amostra.

De acordo com os critérios já descritos anteriormente, a extração inicial de fatores foi feita mediante análise dos componentes principais. Foi realizado o tratamento pairwise para os casos omissos. A análise dos componentes principais sugeriu uma estrutura empírica com 8 componentes, que explicam, em conjunto, $72,70 \%$ da variância total das respostas dos participantes aos itens do questionário. Foi seguido o critério dos eigenvalues (valores próprios) dos fatores maiores ou iguais a 1 (um). Considerando a importância de cada fator, cada um deles deveria explicar no mínimo 3\% da variância total. Dessa maneira, chegou-se ao valor máximo de 8 fatores a serem extraídos. Ao realizar a análise do scree plot, foi verificada a existência de 5 a 6 fatores, como pode ser observado na figura 9:

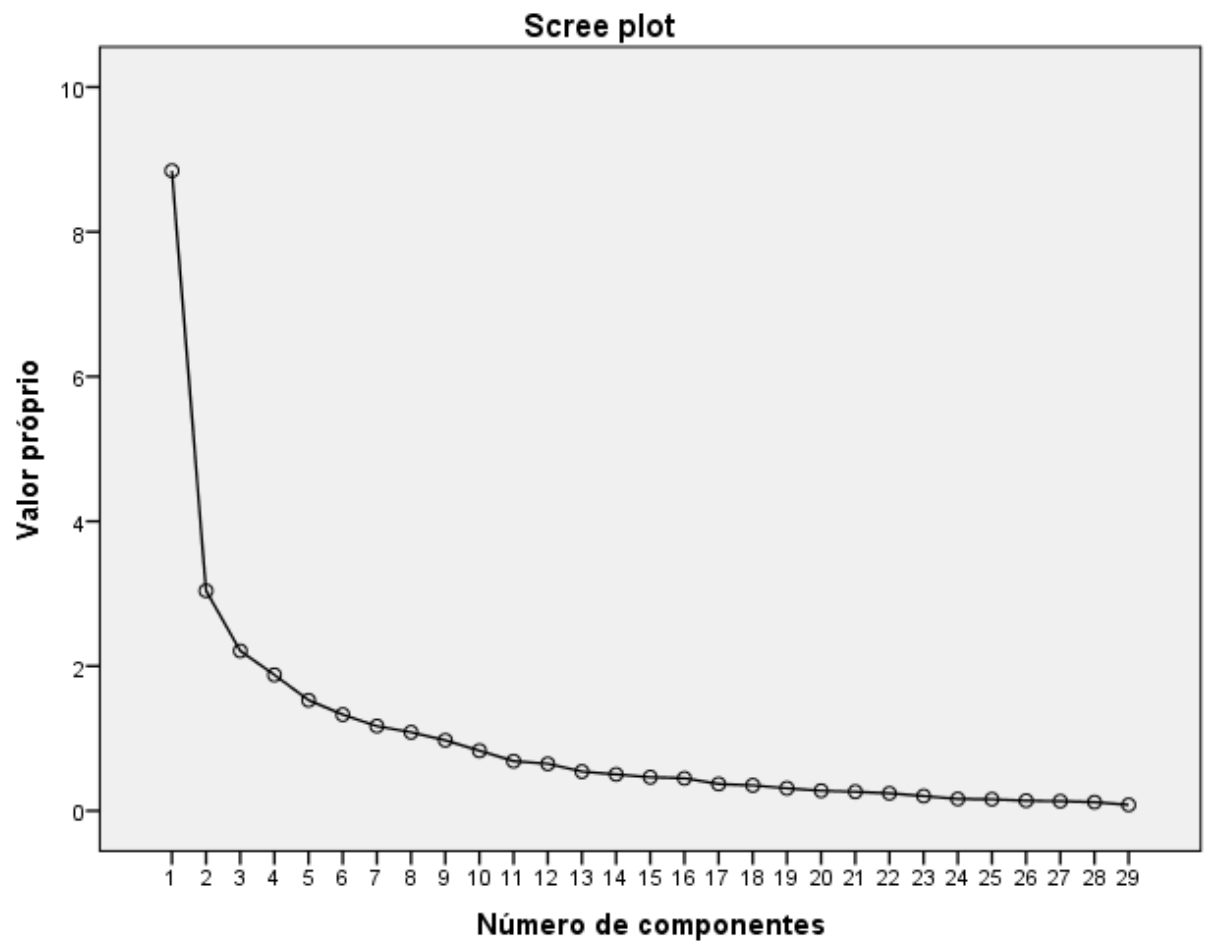

Figura 9: Distribuição dos valores próprios (scree plot) da escala de Estratégias de Aprendizagem. 
A análise paralela de Horn, por sua vez, apontou 4 fatores para este instrumento. Como demonstrado na Tabela 19, apenas os fatores com valores empíricos maiores ou iguais aos valores aleatórios são mantidos na estrutura.

Tabela 19. Valores próprios empíricos e aleatórios dos primeiros sete componentes de Estratégias de Aprendizagem

\begin{tabular}{|c|c|c|c|c|c|c|c|}
\hline \multirow{2}{*}{$\begin{array}{c}\text { Valores } \\
\text { próprios }\end{array}$} & \multicolumn{7}{|c|}{ Componentes } \\
\hline & 1 & 2 & 3 & 4 & 5 & 6 & 7 \\
\hline Empírico & 8,84 & 3,04 & 2,21 & 1,87 & 1,52 & 1,32 & 1,17 \\
\hline Aleatório & 1,98 & $\mathbf{1 , 8 3}$ & 1,72 & 1,62 & 1,53 & 1,46 & 1,39 \\
\hline
\end{tabular}

A tabela 19 demonstra que os quatro primeiros fatores explicam maior variância do que os fatores correspondentes nos dados aleatórios. Sendo assim, a partir da análise paralela, foi possível definir uma estrutura com 4 fatores.

Para de confirmar de maneira definitiva a estrutura fatorial do instrumento, foi realizada a $P A F$, com método de rotação oblíqua e tratamento pairwise para casos omissos. Devido ao fato de que o Instrumento de Estratégias de Aprendizagem já vem sido constantemente validado para diversos contextos - aqui podemos citar o exemplo de Zerbini (2007) e Martins (2012), decidiu-se incluir na escala apenas os itens com cargas fatoriais iguais ou superiores a 0,40. Tal análise permitiu a extração de 4 fatores que explicam, respectivamente, 28,78\%, 8,79\%, 5,96\% e 4,74\% da variância total das respostas aos itens do instrumento. Somados explicam, portanto, 48,27\% da variância total. A opção pela solução com 4 fatores faz sentido empírico e teórico, considerando a literatura anterior de Estratégias de Aprendizagem.

A tabela 20 apresenta a estrutura empírica da escala, as cargas fatoriais, as comunalidades $\left(h^{2}\right)$ dos itens, as médias e desvios-padrão, os índices de consistência interna os valores próprios e percentuais de variância explicada de cada fator. 
Tabela 20. Estrutura empírica da Escala de Estratégias de Aprendizagem

\begin{tabular}{|c|c|c|c|c|c|c|c|}
\hline \multirow{2}{*}{ Descrição dos itens } & \multicolumn{4}{|c|}{ Cargas fatoriais } & \multirow[t]{2}{*}{$\mathbf{h}^{2}$} & \multirow[t]{2}{*}{$\mathbf{X}$} & \multirow[t]{2}{*}{ DP } \\
\hline & 1 & 2 & 3 & 4 & & & \\
\hline 1. Mantive a calma quando tive dificuldades. & & 0,72 & & & 0,53 & 7,22 & 2,32 \\
\hline $\begin{array}{l}\text { 2. Repeti a mim mesmo, quando me senti ansioso, que tudo } \\
\text { sairia bem ao final do curso. }\end{array}$ & & & & & 0,32 & 7,54 & 2,60 \\
\hline $\begin{array}{l}\text { 3. Mantive a calma com a possibilidade de ter um rendimento } \\
\text { abaixo do esperado. }\end{array}$ & & 0,78 & & & 0,60 & 6,47 & 2,48 \\
\hline $\begin{array}{l}\text { 4. Mantive a calma diante dos erros que cometi ao realizar } \\
\text { atividades do curso. }\end{array}$ & & 0,60 & & & 0,43 & 6,81 & 2,48 \\
\hline $\begin{array}{l}\text { 5. Esforcei-me mais quando percebi que estava perdendo a } \\
\text { concentração. }\end{array}$ & 0,57 & & & & 0,59 & 7,65 & 2,27 \\
\hline $\begin{array}{l}\text { 6. Forcei-me a manter a atenção nos estudos quando me senti } \\
\text { desinteressado. }\end{array}$ & 0,63 & & & & 0,50 & 7,55 & 2,31 \\
\hline $\begin{array}{l}\text { 7. Esforcei-me mais quando percebi que estava perdendo o } \\
\text { interesse no assunto. }\end{array}$ & 0,55 & & & & 0,40 & 7,13 & 2,54 \\
\hline $\begin{array}{l}\text { 8. Revisei a matéria para verificar o quanto eu dominava o } \\
\text { conteúdo. }\end{array}$ & 0,44 & & & & 0,42 & 6,83 & 2,37 \\
\hline $\begin{array}{l}\text { 9. Esforcei-me para verificar minha compreensão sobre o que } \\
\text { estava sendo ensinado. }\end{array}$ & 0,66 & & & & 0,71 & 7,88 & 1,88 \\
\hline $\begin{array}{l}\text { 10. Busquei solucionar minhas dúvidas ao consultar as } \\
\text { apostilas do curso. }\end{array}$ & 0,50 & & & & 0,52 & 8,06 & 2,20 \\
\hline $\begin{array}{l}\text { 11. Busquei compreender melhor os conteúdos ao estudá-los } \\
\text { nas apostilas do curso. }\end{array}$ & 0,51 & & & & 0,57 & 7,88 & 2,09 \\
\hline $\begin{array}{l}\text { 12. Busquei auxílio do tutor para esclarecer minhas dúvidas } \\
\text { sobre o conteúdo. }\end{array}$ & & & 0,43 & & 0,35 & 6,16 & 3,08 \\
\hline $\begin{array}{l}\text { 13. Busquei auxílio de colegas nos fóruns para esclarecer } \\
\text { minhas dúvidas. }\end{array}$ & & & 0,58 & & 0,37 & 4,87 & 3,35 \\
\hline $\begin{array}{l}\text { 14. Troquei mensagens com os colegas para esclarecer } \\
\text { dúvidas sobre o conteúdo do curso. }\end{array}$ & & & 0,44 & & 0,26 & 6,77 & 3,20 \\
\hline $\begin{array}{l}\text { 15. Busquei outras fontes de pesquisa, fora da internet, } \\
\text { relacionadas ao curso para me ajudar a aprender. }\end{array}$ & & & & $-0,67$ & 0,51 & 7,92 & 2,72 \\
\hline $\begin{array}{l}\text { 16. Busquei sites relacionados ao conteúdo do curso para me } \\
\text { ajudar a aprender. }\end{array}$ & & & & $-0,60$ & 0,46 & 8,35 & 2,25 \\
\hline $\begin{array}{l}\text { 17. Tentei entender o conteúdo ao aplicá-lo na prática, ao } \\
\text { invés de dedicar tempo lendo ou pedindo ajuda a alguém. }\end{array}$ & & & 0,60 & & 0,41 & 5,54 & 2,79 \\
\hline $\begin{array}{l}\text { 18. Revisei os conteúdos relativos aos exercícios em que } \\
\text { cometi erros. }\end{array}$ & & & & & 0,41 & 6,91 & 2,42 \\
\hline $\begin{array}{l}\text { 19. Aprendi conteúdos ao mentalizá-los repetidamente até } \\
\text { perceber que havia entendido. }\end{array}$ & & & 0,80 & & 0,59 & 5,53 & 2,89 \\
\hline $\begin{array}{l}\text { 20. Repeti mentalmente os conteúdos do curso que gostaria de } \\
\text { aprender. }\end{array}$ & & & 0,79 & & 0,60 & 5,76 & 2,83 \\
\hline 21. Fiz anotações sobre o conteúdo do curso. & 0,47 & & & & 0,51 & 7,69 & 2,63 \\
\hline 22. Fiz resumos do conteúdo do curso. & & & & & 0,57 & 6,98 & 2,94 \\
\hline $\begin{array}{l}\text { 23. Li o conteúdo do curso várias vezes como método para } \\
\text { aprender. }\end{array}$ & & & 0,52 & & 0,51 & 6,10 & 2,83 \\
\hline $\begin{array}{l}\text { 24. Fiz esquemas do conteúdo do curso como método para } \\
\text { aprender. }\end{array}$ & & & 0,53 & & 0,55 & 6,42 & 3,02 \\
\hline $\begin{array}{l}\text { 25. Refleti sobre as implicações que os conteúdos aprendidos } \\
\text { poderiam ter. }\end{array}$ & 0,81 & & & & 0,61 & 7,72 & 2,08 \\
\hline
\end{tabular}


Tabela 20. Estrutura empírica da Escala de Estratégias de Aprendizagem (continuação)

\begin{tabular}{|c|c|c|c|c|c|c|c|}
\hline \multirow[t]{2}{*}{ Descrição dos itens } & \multicolumn{4}{|c|}{ Cargas fatoriais } & \multirow[t]{2}{*}{$\mathbf{h}^{2}$} & \multirow[t]{2}{*}{$\mathbf{X}$} & \multirow[t]{2}{*}{ DP } \\
\hline & 1 & 2 & 3 & 4 & & & \\
\hline $\begin{array}{l}\text { 27. Associei os conteúdos do curso aos meus conhecimentos } \\
\text { anteriores. }\end{array}$ & 0,40 & & & & 0,30 & 8,45 & 1,83 \\
\hline $\begin{array}{l}\text { 28. Diferenciei, ao analisar os conteúdos do curso, os aspectos } \\
\text { mais importantes dos menos importantes. }\end{array}$ & & & & & 0,32 & 7,45 & 2,35 \\
\hline $\begin{array}{l}\text { 29. Identifiquei situações diárias em que eu pudesse aplicar os } \\
\text { conteúdos do curso. }\end{array}$ & 0,61 & & & & 0,44 & 7,82 & 2,08 \\
\hline $\mathrm{N}$ & 122 & 131 & 125 & 131 & & & \\
\hline Eigenvalue (Valor próprio) & 8,34 & 2,54 & 1,73 & 1,37 & & & \\
\hline \% da variância explicada & 28,78 & 8,79 & 5,96 & 4,74 & & & \\
\hline $\mathrm{N}^{\mathrm{o}}$ de itens & 12 & 3 & 8 & 2 & & & \\
\hline $\operatorname{Alfa}(\alpha)$ & 0,90 & 0,81 & 0,83 & 0,80 & & & \\
\hline
\end{tabular}

O instrumento de Estratégias de Aprendizagem (ANEXO F) possui 25 itens e é formado por 4 fatores que foram chamados de: Fator 1 "Estratégias Autorregulatórias", Fator 2 "Controle da Emoção", Fator 3 "Estratégias Cognitivas" e Fator 4 "Estratégias Comportamentais".

Os itens 2 "Repeti a mim mesmo, quando me senti ansioso, que tudo sairia bem ao final do curso", 18 "Revisei os conteúdos relativos aos exercícios em que cometi erros”, 22 “Fiz resumos do conteúdo do curso" e 28 "Diferenciei, ao analisar os conteúdos do curso, os aspectos mais importantes dos menos importantes" não permaneceram na estrutura por não possuírem cargas fatoriais iguais ou maiores que 0,40 , positivas ou negativas. Desses quatro itens, três pertencem ao fator de Estratégias Cognitivas de Martins (2012), e um pertence ao fator Controle de Emoção. Era esperado que algumas Estratégias não fossem utilizadas pela amostra, pois dado o contexto, o uso e frequência das mesmas pode se alterar, como dito anteriormente.

O Fator 1, Estratégias Autorregulatórias, apresenta um total de 11 itens e possui um excelente índice de consistência interna $(\alpha=0,90)$, com cargas fatoriais variando entre 0,40 e 0,86. Dos 12 itens pertencentes a esse fator, 7 pertencem ao fator Estratégias Autorregulatórias de Martins (2012) e 5 ao fator "Estratégias Cognitivas". Desse último fator, foram agrupados os itens relacionados a elaboração, além das Autorregulatórias de controle da motivação e monitoramento da compreensão. Parece curiosa a junção de Estratégias Autorregulatórias e Estratégias Cognitivas. Porém, cabe destacar que todos os itens desse fator, de alguma maneira, estão relacionados a esforços pessoais para facilitar a aprendizagem. Por isso, o nome do fator permaneceu Estratégias Autorregulatórias.

O Fator 2, Controle da Emoção, apresenta um total de 3 itens e possui um bom índice de consistência interna $(\alpha=0,81)$, com cargas fatoriais variando entre 0,60 e 0,78 . Todos os três 
itens pertencentes a esse fator, pertencem ao Controle da Emoção de Martins (2012), corroborando assim a literatura anterior. $\mathrm{O}$ item 2, que anteriormente estava incluso nesse fator e neste estudo deixou de fazer parte do modelo, pode ter sido eliminado por um perfil dos alunos, que na amostra participante, pode não apresentar ansiedade demasiada.

O Fator 3, Estratégias Cognitivas, é composto por 8 itens e apresenta um bom índice de consistência interna $(\alpha=0,81)$, com cargas fatoriais variando entre 0,43 e 0,80 . O fator apresenta, dentre os 8 itens, 3 pertencentes ao fator de Ajuda Interpessoal de Martins (2012) e 5 pertencentes ao fator de Estratégias Cognitivas. Apresenta itens de busca de ajuda interpessoal, aplicação prática, repetição e organização. Tal organização é diferente do apresentado por Warr e Allan (1998), pois une em um único item estratégias Cognitivas e Comportamentais. A justificativa para essa junção, nesse caso, pode se dar pelo fato que os estudantes da amostra fazem uso da ajuda interpessoal (a grande maioria das vezes realizadas através de fóruns online) de maneira cognitiva. Ou seja, suas interações são voltadas para a realização de trabalho, discussão de exercícios, que são atividades cognitivas.

O Fator 4, denominado de Estratégias Comportamentais possui dois itens, possui um bom índice de consistência interna $(\alpha=0,81)$ e cargas fatoriais variando de $-0,60$ a $-0,67$. O fator apresentou dois itens anteriormente descritos no fator de Estratégias Cognitivas de Martins (2012), porém, de acordo com a definição de Warr e Allan (1998), seriam Estratégias Comportamentais de busca de ajuda no material didático, que em sua definição fala da obtenção de informações em documentos escritos, manuais de instruções, programas de computador e outras fontes que não envolvam contato social. Esse é o caso dos itens relatados nesse fator, que tratam da busca de ajuda em sites e fontes fora da internet para ajudar nos estudos.

\subsubsection{Síntese dos resultados: verificação de evidências de validade dos instrumentos}

A tabela 21 abaixo apresenta um resumo dos dados dos instrumentos aplicados no presente estudo, que passaram por análises exploratórias, tal como descrito nas seções anteriores, para verificação de evidências de validade dos mesmos. 
Tabela 21. Resumo das informações sobre os instrumentos utilizados nesta pesquisa.

\begin{tabular}{clccccc}
\hline \multirow{2}{*}{ Instrumento } & \multicolumn{1}{c}{ Escalas Obtidas } & $\begin{array}{c}\mathbf{N}^{\mathbf{0}} \\
\text { de }\end{array}$ & & \multicolumn{2}{c}{ Cargas fatoriais } \\
\cline { 5 - 7 } & & itens & Alfa & Mínima & Máxima \\
\hline \multirow{2}{*}{$\begin{array}{c}\text { Estilos de } \\
\text { Aprendizagem }\end{array}$} & Ambiente de Estudo & 2 & 0,76 & 0,61 & 0,86 \\
& Regulação Externa & 4 & 0,63 & 0,39 & 0,85 \\
& Interação Interpessoal & 2 & 0,40 & 0,31 & 0,84 \\
\hline \multirow{2}{*}{ Estratégias de } & Estratégias Autorregulatórias & 12 & 0,90 & 0,40 & 0,86 \\
Aprendizagem & Controle da Emoção & 3 & 0,81 & 0,60 & 0,78 \\
& Estratégias Cognitivas & 8 & 0,83 & 0,43 & 0,80 \\
& Estratégias Comportamentais & 2 & 0,80 & $-0,60$ & $-0,67$ \\
\hline
\end{tabular}

Observa-se, a partir da tabela 21, que os índices de confiabilidade variaram de 0,40 a 0,90, indicando que as escalas, em sua maioria, apresentam consistência interna. É importante destacar que o instrumento de Estilos de Aprendizagem passou por validação estatística pela primeira vez no presente estudo, o que justifica suas cargas fatoriais um de valores menores que o instrumento de Estratégias de Aprendizagem, que vem passando por constantes revisões e validações. As cargas fatoriais, por sua vez, variaram de 0,31 a 0,86 , o que indica que as escalas são válidas e contemplam itens representativos do fator.

Na próxima seção serão apresentados resultados relativos a alguns testes complementares realizados com os instrumentos envolvendo a questão acerca da possibilidade de evasão e os dados sociodemográficos.

\subsection{Análises Complementares sobre as Escalas: ANOVAS e Testes $t$}

Com o objetivo de complementar os resultados obtidos nas análises exploratórias das estruturas empíricas e investigar um pouco mais a fundo a questão da evasão, bem como os dados sociodemográficos, foram realizados testes de diferença de médias (ANOVA e Teste $t$ ). Tais testes visam identificar possíveis diferenças significativas de variáveis sociodemográficas e a possibilidade de evasão quanto aos escores fatoriais obtidos após as análises fatoriais exploratórias. Também foi possível identificar algumas características do aluno que abandonaria o curso por algum motivo.

Para realizar essas análises, as médias das respostas dos participantes às escalas de Estratégias de Aprendizagem e Estilos de Aprendizagem foram transformadas na variávelcritério dos modelos. As variáveis inseridas separadamente nos modelos foram: sexo, idade, escolaridade, estado civil, renda mensal, profissão, composição familiar, número de filhos, 
experiência anterior no uso da internet. Para verificar o perfil do aluno passível de evasão, a variável critério foi a resposta à questão relacionada ao abandono do curso por algum motivo, e as demais (incluindo as médias das respostas aos questionários) foram inseridas separadamente.

Os resultados das comparações de médias estão representados nas tabelas 22, 23, 24 e 25.

Tabela 22. Teste de diferença entre médias (Teste $t$ ), segundo a resposta se abandonaria o curso.

\begin{tabular}{|c|c|c|c|c|c|}
\hline $\begin{array}{l}\text { Abandonaria o curso por algum } \\
\text { motivo* }\end{array}$ & Média & $\begin{array}{l}\text { Desvio- } \\
\text { Padrão }\end{array}$ & $t$ & $g l$ & $P * *$ \\
\hline \multicolumn{6}{|c|}{ Média Estratégias de Aprendizagem - Estratégias Autorregulatórias (Fator1Estratégia) } \\
\hline Não & 8,21 & 1,26 & 2,13 & 77 & 0,036 \\
\hline $\operatorname{Sim}$ & 7,58 & 1,36 & & & \\
\hline \multicolumn{6}{|c|}{ Média Estratégias de Aprendizagem - Estratégias Comportamentais (Fator4Estratégia) } \\
\hline Não & 8,92 & 1,24 & 2,40 & 84 & 0,018 \\
\hline Sim & 7,81 & 2,73 & & & \\
\hline \multicolumn{6}{|c|}{ Média Estilos de Aprendizagem - Ambiente de Estudo (Fator1Estilos) } \\
\hline Não & 4,77 & 0,36 & 2,23 & 85 & 0,028 \\
\hline Sim & 4,45 & 0,88 & & & \\
\hline \multicolumn{6}{|c|}{ Sexo*** } \\
\hline Não & 1,66 & 0,47 & 2,63 & 86 & 0,01 \\
\hline Sim & 1,39 & 0,49 & & & \\
\hline \multicolumn{6}{|l|}{ *Não N=44; Sim N=44 } \\
\hline \multicolumn{6}{|l|}{$* *$ Considerando $\mathrm{p}<0,05$} \\
\hline
\end{tabular}

Com o intuito de estudar dois grupos homogêneos, foi selecionada uma amostra do grupo que não abandonaria o curso do mesmo tamanho da amostra dos alunos que abandonariam. Sendo assim, ficaram dois grupos de 44 participantes.

Como apresentado na Tabela 22, o resultado do teste de diferença entre médias (Teste $t$ ), considerando $\mathrm{p}<0,05$, mostra que o participante que não abandonaria o curso utiliza com mais frequência as Estratégias de Aprendizagem Autorregulatórias do que o participante que abandonaria o curso por algum motivo. $\mathrm{O}$ grupo que não abandonaria apresentou média igual a 8,21 ( $\mathrm{DP}=1,26)$, enquanto que o grupo dos alunos que abandonariam apresentou média igual a 7,58 (DP=1,36), para um valor do teste $t$ igual a $2,13(\mathrm{gl}=77 ; \mathrm{p}=0,036)$. $\mathrm{O}$ grupo que não abandonaria o curso também utiliza com mais frequência as Estratégias de Aprendizagem Comportamentais, apresentando uma média de 8,92 ( $\mathrm{DP}=1,24)$, enquanto o grupo que 
abandonaria o curso apresentou uma média de 7,81 (DP=2,73), para um valor do teste $t$ igual a 2,40 (gl=84; $\mathrm{p}=0,018)$.

Em relação aos Estilos de Aprendizagem, os alunos que não abandonariam o curso valorizam mais os aspectos do ambiente no qual no qual realizam seus estudos, apresentando uma maior média de Ambiente de Estudo $(M=4,77 ; \mathrm{DP}=0,36)$ do que os alunos que abandonariam o curso $(\mathrm{M}=4,45 ; \mathrm{DP}=0,88)$. $\mathrm{O}$ valor do teste $t$ nesse caso foi de 2,23 ( $\mathrm{gl}=85$; $\mathrm{p}=0,028$ ). Por fim, a maioria dos alunos que não abandonam o curso são do sexo feminino. Considerando que foi utilizado o valor 1 para o sexo masculino e o valor 2 para o sexo feminino, quanto mais próximo de 2 , mais mulheres possui esse grupo. Ou seja, o grupo com maior média possui mais mulheres. Observando a média dos alunos que não abandonariam o curso $(M=1,66 ; D P=0,47)$ e a média dos alunos que abandonariam $(M=1,39$; $D P=0,49)$, podese concluir que o primeiro grupo é formado majoritariamente por mulheres, para um teste $t$ de valor 2,63 ( $\mathrm{gl}=86 ; \mathrm{p}=0,01)$.

A tabela 23 demonstra os resultados do teste de diferença entre médias (Teste $t$ ), segundo o sexo dos participantes, considerando $\mathrm{p}<0,05$. Pode-se observar que os participantes do sexo Masculino utilizam com mais frequência as Estratégias de Aprendizagem de Controle da Emoção do que os participantes do sexo feminino. O grupo dos homens apresentou uma média de 7,36 ( $\mathrm{DP}=2,02)$, enquanto o grupo das mulheres apresentou uma média de 6,39 $(\mathrm{DP}=1,77)$, para um valor do teste $t$ de 2,56 ( $\mathrm{gl}=109 ; \mathrm{p}=0,012)$. Aqui, novamente, em busca de grupos homogêneos, foi selecionada uma amostra de homens com um número igual da amostra de mulheres.

Tabela 23. Teste de diferença entre médias (Teste $t$ ), segundo o sexo dos participantes

\begin{tabular}{|c|c|c|c|c|c|}
\hline Sexo* & Média & $\begin{array}{l}\text { Desvio- } \\
\text { Padrão } \\
\end{array}$ & $t$ & $g l$ & $P * *$ \\
\hline \multicolumn{6}{|c|}{ Média Estratégias de Aprendizagem - Controle da emoção (Fator2Estratégia) } \\
\hline Masculino & 7,36 & 2,02 & 2,56 & 109 & 0,012 \\
\hline Feminino & 6,39 & 1,77 & & & \\
\hline
\end{tabular}

*Masculino N=57; Feminino N=57

$* *$ Considerando $\mathrm{p}<0,05$

O Teste $t$ também foi utilizado para verificar a diferença entre médias dos escores das escalas de acordo com a composição familiar dos participantes (se possui filhos ou não). A Tabela 24 demonstra que os alunos que possuem filhos valorizam mais os aspectos do ambiente no qual no qual realizam seus estudos, apresentando uma maior média de Ambiente 
de Estudo ( $M=4,68 ; \mathrm{DP}=0,61)$ do que os alunos não possuem filhos $(\mathrm{M}=4,37 ; \mathrm{DP}=0,91)$ para um teste $t$ de valor 2,41 ( $\mathrm{gl}=132 ; \mathrm{p}=0,017)$, considerando $\mathrm{p}<0,05$.

Tabela 24. Teste de diferença entre médias (Teste $t$ ), segundo a composição familiar dos alunos.

\begin{tabular}{|c|c|c|c|c|c|}
\hline Composição familiar* & Média & $\begin{array}{l}\text { Desvio- } \\
\text { Padrão }\end{array}$ & $t$ & $g l$ & $P^{* * *}$ \\
\hline \multicolumn{6}{|c|}{ Média Estilos de Aprendizagem - Ambiente de Estudo (Fator1Estilos) } \\
\hline Possui filhos & 4,68 & 0,61 & 2,41 & 132 & 0,017 \\
\hline Não possui filhos & 4,37 & 0,91 & & & \\
\hline
\end{tabular}

Para realizar a comparação dos grupos de renda mensal e médias dos escores das escalas, foi realizado o teste de diferença entre médias ANOVA. A tabela 25 apresenta os resultados, segundo a renda dos participantes, considerando $\mathrm{p}<0,05$.

Tabela 25. Teste de diferença entre médias (ANOVA), segundo a renda mensal dos participantes.

\begin{tabular}{|c|c|c|c|c|c|}
\hline Renda Mensal & Média & $\begin{array}{l}\text { Desvio- } \\
\text { Padrão }\end{array}$ & $\boldsymbol{F}$ & $g l$ & $P^{*}$ \\
\hline \multicolumn{6}{|c|}{ Média Estilos de Aprendizagem - Interação Interpessoal (Fator3Estilos) } \\
\hline Até um salário mínimo & 2,25 & 1,06 & 5,56 & 3 & 0,001 \\
\hline 2 a 3 salários mínimos & 3,31 & 0,97 & & & \\
\hline 4 a 5 salários mínimos & 3,3 & 0,91 & & & \\
\hline 6 ou mais salários mínimos & 3,19 & 1,08 & & & \\
\hline \multicolumn{6}{|c|}{ Média Estratégias de Aprendizagem - Estratégias Cognitivas (Fator3Estratégia) } \\
\hline Até um salário mínimo & 4,6 & 1,92 & 3,97 & 3 & 0,01 \\
\hline 2 a 3 salários mínimos & 6,46 & 1,88 & & & \\
\hline 4 a 5 salários mínimos & 6,01 & 2,02 & & & \\
\hline 6 ou mais salários mínimos & 5,54 & 2,15 & & & \\
\hline
\end{tabular}

Observando a tabela 25, verifica-se que existem diferenças significativas entre as médias dos grupos definidos a partir da renda mensal em comparação com as médias obtidas no uso de Estilos de Aprendizagem de Interação Interpessoal. As médias variaram de 3,31 a 2,25, nesta ordem: 2 a 3 salários mínimos $(\mathrm{M}=3,31 ; \mathrm{DP}=0,97) ; 4$ a 5 salários mínimos $(\mathrm{M}=3,30$; $\mathrm{DP}=0,91) ; 6$ ou mais salários mínimos $(\mathrm{M}=3,19 ; \mathrm{DP}=1,08)$; até um salário mínimo $(\mathrm{M}=2,25$; $\mathrm{DP}=1,06)$, para um valor da ANOVA igual a 5,56 $(\mathrm{gl}=3 ; \mathrm{p}=0,001)$. A análise Post Hoc demonstrou, por sua vez, que os participantes com renda de 2 a 3 salários mínimos preferem mais estudar com outros alunos do que os participantes que possuem renda de até um salário mínimo ( $\mathrm{p}=0,01$ ). Da mesma maneira, os participantes com renda de 4 a 5 salários mínimos 
também preferem mais estudar com outros alunos do que os alunos que possuem renda de até um salário mínimo $(\mathrm{p}=0,04)$.

A tabela também mostra que existem diferenças significativas entre as médias dos grupos definidos a partir da renda mensal em comparação com as médias obtidas no uso de Estratégias de Aprendizagem Cognitivas. As médias variaram de 6,46 a 4,6, nesta ordem: 2 a 3 salários mínimos $(\mathrm{M}=6,46 ; \mathrm{DP}=1,88) ; 4$ a 5 salários mínimos $(\mathrm{M}=6,01 ; \mathrm{DP}=2,02) ; 6$ ou mais salários mínimos $(\mathrm{M}=5,54 ; \mathrm{DP}=2,15)$; até um salário mínimo $(\mathrm{M}=4,60 ; \mathrm{DP}=1,92)$, para um valor da ANOVA igual a 3,97 (gl=3; p=0,01). Porém, ao realizar a análise Post Hoc, não foi apresentada diferença significativa entre os grupos.

O resumo dos achados nos Testes $t$ e ANOVA são apresentados de maneira resumida na tabela 26 abaixo:

Tabela 26: Resumo dos resultados das análises de diferenças de médias (Teste $t$ e ANOVA)

\begin{tabular}{ll}
\hline \multicolumn{1}{c}{ Variável } & \multicolumn{1}{c}{ Resultado } \\
\hline O participante do sexo masculino... & $\begin{array}{l}\text { 1. Abandona o curso com mais facilidade. } \\
\text { 2. Faz mais uso da Estratégia de } \\
\text { Aprendizagem Controle da Emoção. }\end{array}$ \\
\hline O participante que possui filhos... & $\begin{array}{l}\text { 1. Valoriza mais os aspectos do Ambiente no } \\
\text { qual realiza seus estudos. }\end{array}$ \\
\hline & $\begin{array}{l}\text { 1. Faz mais uso das Estratégias de } \\
\text { Aprendizagem Autorregulatórias. }\end{array}$ \\
O participante que não abandonaria o curso & $\begin{array}{l}\text { 2. Faz mais uso das Estratégias de } \\
\text { Aprendizagem Comportamentais. } \\
\text { por motivo algum... }\end{array}$ \\
$\begin{array}{l}\text { 3. Valoriza mais os aspetos do Ambiente no } \\
\text { qual realiza seus estudos. }\end{array}$ \\
$\begin{array}{ll}\text { O participante com renda de } 2 \text { a } 5 \text { salários mais uso das Estratégias de } \\
\text { mínimos... }\end{array}$ \\
\hline
\end{tabular}

A Tabela 26 demonstra que os participantes do sexo masculino abandonam o curso com mais facilidade, e fazem mais uso da Estratégia de Aprendizagem Controle da Emoção. Os participantes que possuem filhos valorizam mais os aspectos do Ambiente no qual realiza seus estudos, possuindo mais preferências relacionadas a ele. Os participantes que não abandonariam o curso por nenhum motivo fazem mais uso das Estratégias de Aprendizagem Autorregulatórias e Comportamentais. Além disso, valorizam mais os aspectos do Ambiente no qual realiza seus estudos, possuindo mais preferências relacionadas a ele. Por fim, os estudantes com renda de 2 a 5 salários mínimos fazem mais uso das Estratégias de Aprendizagem Comportamentais. 
Na próxima seção serão apresentados os resultados resultantes da validação convergente dos instrumentos de Estilos de Aprendizagem e Estratégias de Aprendizagem.

\subsection{Validade Convergente dos instrumentos de Estratégias de Aprendizagem e Estilos de Aprendizagem}

Para cumprir com um dos objetivos dessa pesquisa, foi realizada a validação convergente dos instrumentos utilizados. Para essa análise, como foi citado anteriormente, foram calculados os escores fatoriais dos dois instrumentos, e os mesmos foram usados para a análise. O objetivo foi verificar quais escores se correlacionam de maneira positiva, negativa, ou simplesmente não se correlacionam significativamente. Sendo assim, pretende-se relacionar os resultados dessa validade com os dados da literatura, propondo uma maior concepção acerca dos conceitos de Estratégias de Aprendizagem e Estilos de Aprendizagem.

A tabela 27 apresenta os resultados da correlação, marcando as correlações significativas para $\mathrm{p}<0,01$.

Tabela 27. Correlação entre os fatores dos instrumentos de Estilos de Aprendizagem e Estratégias de Aprendizagem

\begin{tabular}{llcccc}
\hline & & $\begin{array}{c}\text { Estratégias } \\
\text { Autorregulatórias }\end{array}$ & $\begin{array}{c}\text { Controle } \\
\text { da emoção }\end{array}$ & $\begin{array}{c}\text { Estratégias } \\
\text { Cognitivas }\end{array}$ & $\begin{array}{c}\text { Estratégias } \\
\text { Comportamentais }\end{array}$ \\
\hline $\begin{array}{l}\text { Ambiente } \\
\text { de Estudo }\end{array}$ & $r$ & $0,60^{*}$ & 0,03 & $0,37^{*}$ & $0,26^{*}$ \\
& $p$ & 0,00 & 0,76 & 0,00 & 0,00 \\
\hline Regulação & $r$ & $0,36^{*}$ & 0,04 & $0,28^{*}$ & 0,21 \\
Externa & $p$ & 0,00 & 0,66 & 0,00 & 0,02 \\
\hline Interação & $r$ & $0,27^{*}$ & $-0,07$ & $0,50^{*}$ & 0,22 \\
Interpessoal & $p$ & 0,00 & 0,42 & 0,00 & 0,01 \\
\hline
\end{tabular}

*correlação significativa para $\mathrm{p}<0,01$

A partir da tabela 27 pode-se notar que o fator Estratégias Autorregulatórias se correlacionou positivamente com os fatores Ambiente de Estudo ( $r=0,60 ; p=0)$, Regulação Externa $(\mathrm{r}=0,36 ; \mathrm{p}=0)$ e Interação Interpessoal $(\mathrm{r}=0,27 ; \mathrm{p}=0)$. Nota-se que sua maior correlação foi apresentada juntamente ao fator Ambiente de Estudo. O fator Controle da emoção não se correlacionou significativamente com nenhum fator do instrumento de Estilos de Aprendizagem. O fator Estratégias Cognitivas também se correlacionou positivamente com os três fatores: Ambiente de Estudo $(r=0,37 ; p=0)$, Regulação Externa $(r=0,28 ; p=0)$ e Interação Interpessoal $(r=0,50 ; p=0)$. A maior correlação desse fator é a apresentada junto ao 
fator Interação Interpessoal. Por fim, o fator Estratégias Comportamentais se correlacionou somente com o fator Ambiente de Estudo ( $r=0,26 ; p=0)$.

A tabela demonstrou muitas correlações, porém, é importante destacar que apenas algumas apresentaram índices elevados, apesar de muitas serem significativas. Das sete correlações significativas, quatro apresentaram índice superior a 0,30 e dessas, apenas duas foram superiores a 0,50. Sendo assim, por mais que os fatores se correlacionem de alguma maneira, eles se correlacionam com índices baixos e medianos.

Os resultados também demonstram que o conceito de Estratégias de Aprendizagem algumas vezes se converge com o conceito de Estilos de Aprendizagem, apresentando baixos índices de correlação em sua maioria. Uma hipótese seria que os instrumentos ainda possuem itens com ambos os conceitos. O fator Controle da Emoção, por não se correlacionar de maneira alguma com os fatores de Estilos de Aprendizagem, indica que não possui relação com o conceito de Estilos de Aprendizagem, o que pode ser considerado um ponto positivo. Nenhum dos fatores se correlacionaram significativamente de modo negativo entre eles, o que indica que os conceitos de Estilos de Aprendizagem e Estratégias de Aprendizagem não possuem definições contrárias entre si.

Após serem apresentados o conjunto de resultados quantitativos, a próxima seção se dedica na apresentação da análise conceitual do construto Estilos de Aprendizagem

\subsection{Estilos de Aprendizagem: Análise Conceitual}

Pretende-se, nessa seção, iniciar a discussão sobre a análise conceitual do construto Estilos de Aprendizagem, para que parte do objetivo geral desta pesquisa seja cumprido. Serão apresentadas definições de diversos autores, das áreas da Psicologia e da Educação. Além disso, os conceitos de Estilos de Aprendizagem e Estratégias de Aprendizagem serão comparados, visando complementar a validação convergente dos instrumentos que foi apresentada nas seções anterior. A presente análise foi motivada pela necessidade de rever o instrumento de Estilos de Aprendizagem após serem encontradas dificuldades na validação estatística do mesmo.

Warr e Allan (1998) destacam a importância de diferenciar os conceitos de Estilos de Aprendizagem e Estratégias de Aprendizagem, pois ambos são importantes no desenho de um evento instrucional, mas de maneiras diferenciadas. Tal comparação tornou-se necessária para uma definição do constructo Estilos de Aprendizagem de acordo com os objetivos dessa pesquisa, bem como a área de estudo a qual ela pertence. Além disso, uma diferenciação entre 
Estilos e Estratégias de aprendizagem foi fundamental na construção do instrumento de Estilos de Aprendizagem, no momento da elaboração e organização dos itens. Nessa comparação, foram selecionados autores brasileiros que pesquisam Estilos de Aprendizagem no contexto do trabalho e organizações, e suas principais referências. A Tabela 28 demonstra os resultados da comparação. 
Estratégias de Aprendizagem são procedimentos utilizados pelos indivíduos durante as atividades de aprendizagem para ser bem sucedido. As estratégias variam mais do que os estilos, já que podem ter a influência das preferências gerais do indivíduo. Além disso, os autores dizem que as estratégias podem ser modificadas em treinamento com o intuito de aumentar a efetividade da aprendizagem em uma atividade ou ambiente específico.

Estratégias de Aprendizagem Cognitiva são compostas pelas estratégias: 1) Repetição (Rehearsal) - repetição mental da informação na forma em que foi apresentada; 2) Organização (Organization) - identificação de idéias centrais do material e criação de esquemas mentais que agrupam e relacionam elementos que foram aprendidos; e 3) Elaboração (Elaboration) - reflexão sobre

Estilos de Aprendizagem são as preferências do estudante referentes aos aspectos contextuais e as maneiras de estudo. Compreendem a preferência dos indivíduos por determinadas Estratégias de Aprendizagem e por aspectos do contexto em que esta ocorre. Exemplo de Estilos de Aprendizagem: nível de ruído e temperatura do ambiente ao estudar, horário de preferência de estudo, forma de estudo (individual, em grupo), maneira de adquirir e processar as informações (pedir ajuda a colegas, consultar o material). implicações e conexões possíveis entre o material aprendido e o conhecimento já existente.

Estratégias de Aprendizagem Comportamentais agrupam as estratégias: 1) Busca de ajuda interpessoal (Interpersonal helpseeking) - obtenção de auxílio de outras pessoas, como pares e professores, para tirar dúvidas sobre o material; 2) Busca de ajuda no material escrito (Seeking help from written material) - obtenção de informações em documentos escritos, manuais de instruções, programas de computador e outras fontes que não envolvam contato social; e 3) Aplicação prática (Practical application) aprimoramento do conhecimento por meio de aplicação prática do que foi aprendido.

Estratégias auto-regulatórias são formadas pelas estratégias: 1) Controle da emoção (Emotion control) - controle da ansiedade e prevenção de dispersões de concentração, causadas por sentimentos de ansiedade; 2) Controle da motivação (Motivation control) - controlar a motivação e a atenção, apesar de existência de um interesse limitado na tarefa a ser aprendida; e 3) Monitoramento da compreensão (Comprehension monitoring) - avaliação do processo de aquisição de aprendizagem e modificação do comportamento do indivíduo. 
Tabela 28. Definição de Estilos e Estratégias de Aprendizagem (continuação).

\section{Autor Estilos de Aprendizagem}

Tendências a usar uma combinação particular de atividades de aprendizagem que o indivíduo pode e gosta de desempenhar.

Salles (2007) Essa combinação são as Estratégias de Aprendizagem.

Diferentes estilos preferem diferentes estratégias. Há um padrão

a longo prazo, mas os estilos podem mudar em cada situação. É portanto, flexível-estável.

Conjunto coerente de atividades de aprendizagem que os indivíduos utilizam frequentemente, de acordo com a orientação e as concepções individuais de aprendizagem. Os Estilos de

Aprendizagem são um construto multidimensional no qual as estratégias regulatórias e as estratégias de processamento são influenciadas pela visão pessoal e pelas atitudes do participante a respeito do evento de treinamento.

Vermunt $(1998,2005)$

\section{Estratégias de Aprendizagem}

Processos utilizados por aprendizes para responder a demandas das atividades de aprendizagem, que podem ser aprendidas e desenvolvidas, e variam com o tempo.

Um estado que muda a cada situação de aprendizagem, determinado pelos estilos.

Fonte: Zerbini (2007), Salles (2007) e Brant (2014). 
Nota-se, de acordo com as definições expostas na Tabela 28, que a principal diferença entre os Estilos de Aprendizagem e as Estratégias de Aprendizagem é que a segunda é passível de treinamento, enquanto a primeira não é. Além disso, Vermunt (1998) fala que as Estratégias são determinadas pelos Estilos.

Falando mais objetivamente da definição de Estilos de Aprendizagem, os autores concordam que a variável é uma preferência do aluno, seja pelo contexto de estudo, ou pela maneira como isso ocorre. Também concordam quando afirmam que o conceito trata da preferência por uma ou outra Estratégia de Aprendizagem. A visão que o treinando tem a respeito do curso também é refletida sobre os Estilos de Aprendizagem, segundo Vermunt (1998).

Indo um pouco mais além, algumas das definições da palavra Estilo segundo o dicionário online Michaelis são: 1) Hábito, prática, praxe, costume; 2) Maneira especial de exprimir os pensamentos, falando ou escrevendo; 3) Maneira de dizer, escrever, compor, pintar ou de esculpir de cada um. Trazendo esses conceitos para a área da Aprendizagem, e unindo com as definições apresentadas pelos autores, pode-se dizer que os Estilos de Aprendizagem é uma característica particular de cada aprendiz, sendo preferências individuais. Em uma sala de aula, portanto, os alunos podem ser totalmente diferentes em relação às suas preferências de estudo, ou seja, seus Estilos de Aprendizagem. A vantagem da EAD, nesse sentido, é que permite a customização e adaptação do ensino para cada aluno, possibilitando atender todas as preferências.

Um fato que merece destaque, é que, por mais que os autores tenham definições parecidas entre si sobre o que é Estilos de Aprendizagem e Estratégias de Aprendizagem, ao comparar os itens dos instrumentos de Estilos de Aprendizagem de Vermunt (1998) e de Brant (2014) e os itens do instrumento de Estratégias de Aprendizagem de Martins (2012) - esse último adaptado de Zerbini (2007), nota-se que os itens dos dois primeiros instrumentos muitas vezes se divergem da definição de Estilos de Aprendizagem e se convergem com a definição de Estratégias de Aprendizagem.

Após realizada a construção do instrumento de Estilos de Aprendizagem e sua posterior Validação Semântica e por Juízes, o mesmo foi submetido a uma revisão, com o objetivo de eliminar itens que não estavam inclusos na definição de Estilos de Aprendizagem dos autores estudados, ou que estavam relacionados à definição de Estratégias de Aprendizagem. Em um segundo momento, o instrumento foi comparado ao de Estratégias de Aprendizagem de Martins (2012), com o intuito de buscar itens semelhantes, eliminando-os. Além disso, foram 
excluídos itens que não estavam contemplados na definição de Estilos de Aprendizagem ou estavam contemplados na definição de Estratégias de Aprendizagem.

O resultado dessa análise está apresentado na tabela a seguir:

Tabela 29: Análise dos itens do instrumento de Estilos de Aprendizagem

\begin{tabular}{|c|c|c|}
\hline & Item & Análise \\
\hline 1) & $\begin{array}{l}\text {...ser crítico em relação às discussões } \\
\text { apresentadas pelos professores/tutores. }\end{array}$ & $\begin{array}{l}\text { Não é contemplado pela definição de Estilos de } \\
\text { Aprendizagem dos autores estudados. }\end{array}$ \\
\hline 2) & $\begin{array}{l}\text {...estudar uma pequena quantidade de } \\
\text { conteúdo por vez. }\end{array}$ & É uma Estratégia de Aprendizagem segundo Zerbini (2007) \\
\hline 3) & $\begin{array}{l}\text {...cursos que atendam meus interesses } \\
\text { profissionais. }\end{array}$ & $\begin{array}{l}\text { É um estilo segundo Brant e Vermunt. Porém, também é } \\
\text { uma Estratégia segundo Zerbini (2007). Optou-se por } \\
\text { excluir do instrumento. }\end{array}$ \\
\hline 4) & $\begin{array}{l}\text {...realizar uma atividade paralela } \\
\text { enquanto estudo, como ouvir música, } \\
\text { assistir televisão, navegar na internet. }\end{array}$ & $\begin{array}{l}\text { Estilo segundo Zerbini (2007) e Leaver (1997). Remete a } \\
\text { preferência ambiental (luz, ruído, etc.). }\end{array}$ \\
\hline 5) & ...estudar no período da noite. & $\begin{array}{l}\text { Estilo de aprendizagem segundo Zerbini (2007). Porém, no } \\
\text { momento da análise fatorial exploratória, a inserção do item } \\
\text { impede da fatoração e validação do instrumento. Por ser a } \\
\text { única literatura encontrada que tratava o item como Estilo de } \\
\text { Aprendizagem, optou-se por excluí-lo. }\end{array}$ \\
\hline 6) & $\begin{array}{l}\text {...que os professores/tutores ofereçam } \\
\text { exemplos de como se deve estudar. }\end{array}$ & $\begin{array}{l}\text { O item sugere a aprendizagem regulada pelos } \\
\text { professores/tutores, que é contemplada por Brant (2014). } \\
\text { Porém, a maneira como o item está redigido não deixa claro } \\
\text { esse objetivo. Sendo assim, o mesmo foi retirado. }\end{array}$ \\
\hline 7) & $\begin{array}{l}\text {...fazer minhas anotações em arquivos } \\
\text { digitais no computador. }\end{array}$ & $\begin{array}{l}\text { Estilo de Aprendizagem segundo Brant. Porém o foco deve } \\
\text { estar em estudar por arquivos digitais e/ou impressos. A } \\
\text { maneira como ele está escrito sugere que ele é uma } \\
\text { Estratégia de Aprendizagem segundo Zerbini (2007). } \\
\text { Retirou-se o item. }\end{array}$ \\
\hline 8) & $\begin{array}{l}\text {...que o material didático facilite meus } \\
\text { estudos. }\end{array}$ & $\begin{array}{l}\text { Não é contemplado pela definição de Estilos de } \\
\text { Aprendizagem dos autores estudados. }\end{array}$ \\
\hline 9) & ...cursos desafiadores. & $\begin{array}{l}\text { Não é contemplado pela definição de Estilos de } \\
\text { Aprendizagem dos autores estudados. }\end{array}$ \\
\hline 10) & $\begin{array}{l}\text {... estudar juntamente com outros } \\
\text { alunos. }\end{array}$ & $\begin{array}{l}\text { Estilo de Aprendizagem segundo Brant (2014), Vermunt } \\
\text { (1998) e Zerbini (2007). Trata da interação. }\end{array}$ \\
\hline
\end{tabular}


Tabela 29: Análise dos itens do instrumento de Estilos de Aprendizagem (continuação)

\begin{tabular}{cl}
\hline \multicolumn{1}{c}{ Item } & \multicolumn{1}{c}{ Análise } \\
\hline 11) ...estudar no período da manhã. & Estilo de aprendizagem segundo Zerbini (2007). Porém, no \\
& momento da análise fatorial exploratória, a inserção do item \\
& impede da fatoração e validação do instrumento. Por ser a \\
& única literatura encontrada que tratava o item como Estilo de \\
& Aprendizagem, optou-se por excluí-lo.
\end{tabular}

12) ...participar das atividades de interação Estilo de Aprendizagem segundo Brant (2014), Vermunt virtual (fóruns, bate-papo) para discutir os conteúdos com os outros estudantes.

13) ...receber instruções detalhadas sobre Estilo de Aprendizagem segundo Brant (2014). Trata da as atividades a serem realizadas no curso.

14) ....ser crítico em relação ao conteúdo Não é contemplado pela definição de Estilos de apresentado no material didático. $\quad$ Aprendizagem dos autores estudados.

15) ...que os professores/tutores expliquem Estilo de Aprendizagem segundo Brant (2014). Trata da claramente o que é importante estudar para alcançar os objetivos propostos no curso.

16) ...avaliar sozinho meu domínio sobre o É Estilo de Aprendizagem segundo Brant (2014), tratando conteúdo apresentado.

regulação da aprendizagem pelos professores/tutores.

da regulação interna da aprendizagem. Porém também é estratégia segundo Zerbini (2007). Optou-se por retirar o item.

17) ...adquirir conhecimentos que sejam Estilo de Aprendizagem segundo Vermunt (1998), tratando úteis para resolução de problemas práticos. da ligação com a prática/carreira. Porém também é estratégia segundo Zerbini (2007), sendo encontrado um item parecido no instrumento de Estratégias de Aprendizagem de Martins (2012). Optou-se por retirar o item.

18) ...cursos que me garantam um diploma/título.

Não é contemplado pela definição de Estilos de Aprendizagem dos autores estudados.

19) ...estudar no período da tarde.

Estilo de aprendizagem segundo Zerbini (2007). Porém, no momento da análise fatorial exploratória, a inserção do item impede da fatoração e validação do instrumento. Por ser a única literatura encontrada que tratava o item como Estilo de Aprendizagem, optou-se por excluí-lo.

20) ...realizar meus estudos em lugares bem iluminados.

Estilo segundo Zerbini (2007) e Leaver (1997). Remete a preferência ambiental (luz, ruído, etc.).

21) ...estudar em ambientes com pouco barulho.

Estilo segundo Zerbini (2007) e Leaver (1997). Remete a preferência ambiental (luz, ruído, etc.).

22) ...decidir sozinho o que é importante É estilo segundo Brant (2014), tratando dar regulação estudar para alcançar os objetivos propostos no curso. interna da aprendizagem. Porém também é estratégia segundo Zerbini (2007). Optou-se por retirar o item. 
Tabela 29: Análise dos itens do instrumento de Estilos de Aprendizagem (continuação)

\begin{tabular}{|c|c|}
\hline Item & Análise \\
\hline 23) ...realizar individualmente as tarefas. & $\begin{array}{l}\text { Questão não respondida por erro do Google Docs, que não } \\
\text { computou as respostas do item. É estilo de aprendizagem } \\
\text { segundo Brant } \quad \text { (2014) e Vermunt } \quad \text { (1998). Trata da } \\
\text { preferência por estudar sozinho/em grupo. Deve permanecer } \\
\text { no próximo questionário. }\end{array}$ \\
\hline $\begin{array}{l}\text { 24) ...que sejam realizadas avaliações de } \\
\text { aprendizagem para verificar meu } \\
\text { domínio do conteúdo apresentado. }\end{array}$ & $\begin{array}{l}\text { Estilo segundo Brant (2014). Trata da regulação da } \\
\text { aprendizagem pelos professores/tutores. }\end{array}$ \\
\hline $\begin{array}{l}\text { 25) ...cursos que auxiliem a descoberta de } \\
\text { minhas qualidades e limitações como } \\
\text { aprendiz. }\end{array}$ & $\begin{array}{l}\text { Não é contemplado pela definição de Estilos de } \\
\text { Aprendizagem dos autores estudados. }\end{array}$ \\
\hline 26) ...ter o material impresso para ler. & $\begin{array}{l}\text { Estilo segundo Brant. Porém o foco deve estar em estudar } \\
\text { por arquivos digitais e/ou impressos. O item foi mantido } \\
\text { com, porém sua redação deverá ser melhorada no próximo } \\
\text { questionário. }\end{array}$ \\
\hline $\begin{array}{l}\text { 27) ...ser lembrado sobre os prazos de } \\
\text { entrega das atividades do curso. }\end{array}$ & $\begin{array}{l}\text { Estilo segundo Brant (2014). Trata da regulação da } \\
\text { aprendizagem pelos professores/tutores. }\end{array}$ \\
\hline
\end{tabular}

Nota-se, portanto, que muitos itens não estavam adequados ao constructo proposto. Muitos deles pertenciam à definição de Estratégias de Aprendizagem ao invés de Estilos de Aprendizagem. Por isso, é importante ter clareza sobre ambas definições. Seja para construção e/ou validação de instrumento, seja para interpretação de resultados que contenham as duas variáveis.

O instrumento de Estratégias de Aprendizagem também foi analisado, e notou-se que: (1) as Estratégias Autorregulatórias de Martins (2012) e os Estilos de Aprendizagem de Regulação interna de Brant (2014) tem a mesma definição; (2) os itens 15 e 16 do instrumento de Estratégias de Aprendizagem: "Busquei outras fontes de pesquisa, fora da internet, relacionadas ao curso para me ajudar a aprender" e "Busquei sites relacionados ao conteúdo do curso para me ajudar a aprender" são chamados por Vermunt (1998) de Estilo de Aprendizagem; e (3) os itens "1. Mantive a calma quando tive dificuldades", "3. Mantive a calma com a possibilidade de ter um rendimento abaixo do esperado", e "4. Mantive a calma diante dos erros que cometi ao realizar atividades do curso" do instrumento de Estratégias de Aprendizagem são definidos por Vermunt (1998) de Estilo de Aprendizagem Autorregulatório. Tanto os itens 15 e 16 quanto os itens 1, 3 e 4 do instrumento de Estratégias de Aprendizagem agruparam-se entre si na Análise Fatorial Exploratória, formando os fatores Estratégias Comportamentais e Controle da Emoção, respectivamente. Seriam esses fatores 
Estilos de Aprendizagem ou Estratégias de Aprendizagem? Para responder essas questões, foi realizada a Validade Convergente entre os instrumentos. A Validade divergente, que deveria ser realizada através da Análise Fatorial Exploratória entre os itens dos dois instrumentos juntos, não pôde ser executada devido ao número de participantes. A amostra não foi suficiente de acordo com o critério de Pasquali (2004) que fala de ao menos 10 participantes para cada variável do estudo.

Considerando que a presente pesquisa está situada na área de conhecimento da POT, incialmente foi estabelecida a referência da área para a definição de Estilos de Aprendizagem. Sendo assim, temos a definição de Warr e Allan (1998) e Zerbini (2007), que diz: "São as preferências do estudante referentes aos aspectos contextuais e as maneiras de estudo. Compreendem a preferência dos indivíduos por determinadas Estratégias de Aprendizagem e por aspectos do contexto em que esta ocorre". Essa definição foi selecionada por tratar dos Estilos de Aprendizagem no contexto de ações educacionais em IES ofertadas à distância. Enquanto as autoras Salles (2007) e Brant (2014) se focaram no contexto do trabalho, presencialmente e à distância, respectivamente.

Levando em consideração todas as análises realizadas no presente estudo, pode se concluir que Estilos de Aprendizagem são preferências do aluno relacionadas ao contexto e ambiente de estudo (luz, ruído, etc.), à maneira como sua aprendizagem é regulada (orientação dos professores/tutores em relação a maneira de estudar) e à sua interação interpessoal (estudar, fazer atividades e trocar informações com colegas do curso).

As análises também demonstraram que o uso de alguns Estilos de Aprendizagem pode levar ao aluno a persistir no curso na modalidade EAD.

Por fim, a validação convergente entre os instrumentos de Estratégias de Aprendizagem e Estilos de Aprendizagem demonstraram que as definições desses construtos ainda estão interligadas algumas vezes na literatura, o que traz à tona a necessidade de um maior aprofundamento em relação às diferenças e semelhanças entre essas duas variáveis.

Após serem apresentados todos os resultados da presente pesquisa, a próxima seção trata da discussão, relacionando os resultados com os achados da literatura. 


\section{CAPÍTULO 6. DISCUSSÃO}

\section{Objetivos do capítulo}

O presente capítulo tem como objetivo discutir os principais resultados da pesquisa, relacionando-os com os objetivos propostos e com resultados obtidos em pesquisas descritas na revisão da literatura. Serão discutidos primeiramente os resultados das análises exploratórias, seguidos da validação convergente dos instrumentos.

\subsection{Discussões dos resultados das análises fatoriais exploratórias}

Os resultados fazem com que o objetivo geral da pesquisa seja parcialmente cumprido, e cumpre com alguns objetivos específicos. Alcança parcialmente o objetivo geral no sentido que constrói e verifica evidências de validade do instrumento de Estilos de Aprendizagem. Os objetivos específicos cumpridos são: (1) Construir e verificar evidências de validade de um instrumento de Estilos de Aprendizagem, com base na definição de Zerbini (2007), e nos instrumentos de Vermunt (1998) e Brant (2014); (2) Verificar evidências de validade da Escala de Estratégias de Aprendizagem (Martins, 2012); (3) Analisar a relação entre o uso de Estratégias de Aprendizagem e Estilos de Aprendizagem com a possibilidade de Evasão do curso; (4) Analisar diferenças entre dados sociodemográficos e utilização de Estratégias de Aprendizagem e Estilos de Aprendizagem.

Os índices de confiabilidade das escalas obtidas variam de 0,40 a 0,90, o que indica que as escalas apresentam consistência interna em sua maioria. As cargas fatoriais, por sua vez, foram de 0,31 a 0,86 , demonstrando validade das escalas obtidas.

As discussões apresentadas a seguir tratam dos instrumentos de Estratégias de Aprendizagem e Estilos de Aprendizagem.

\section{$\underline{\text { Estilos de Aprendizagem }}$}

As estatísticas descritivas mostram que dentre os itens que permaneceram no questionário, os que apresentaram maiores médias, em ordem decrescente, foram: 20) Realizar meus estudos em lugares bem iluminados $(\mathrm{M}=4,59 ; \mathrm{DP}=0,82)$; 21) Estudar em ambientes com pouco barulho $(\mathrm{M}=4,54 ; \mathrm{DP}=0,87)$ e 26) Ser lembrado sobre os prazos de entrega das atividades do curso $(\mathrm{M}=4,41 ; \mathrm{DP}=0,97)$. Os dois primeiros representam o fator 1 (Ambiente de Estudo) e o terceiro pertence ao fator 2 (Regulação Externa). Dessa maneira, pode-se 
concluir que os alunos da presente amostra concentram suas preferências no ambiente no qual realizam seus estudos.

O instrumento final de Estilos de Aprendizagem, após passar pela revisão e consequente análise conceitual do construto, ficou com apenas 8 itens. $\mathrm{O}$ instrumento deve receber novos itens, especialmente nos fatores Interação Interpessoal e Ambiente de Estudo que contam somente com dois itens cada um. Deve ser realizada a tentativa de inclusão de novos itens, para que seja verificado se o construto Estilos de Aprendizagem é contemplado somente por esses itens do instrumento ou pode haver outros itens que são abordados pela definição. É importante salientar que a inserção de novos itens deve respeitar a definição do construto.

Em relação aos 10 itens finais obtidos após a revisão do instrumento e análise conceitual do construto, nenhum deles apresentou elevados índices de correlação e foram extraídos três fatores, a saber: Ambiente de Estudo, Regulação Externa e Interação Interpessoal.

O item “...realizar individualmente as tarefas” não foi computado pelo Google Docs, ou seja, as respostas a essa questão não foram gravadas. Sendo assim, sugere-se que em uma próxima aplicação o item seja incluído novamente, pois, segundo a definição de Brant (2014) e Vermunt (1998), trata de um Estilo de Aprendizagem.

O item 23 "Que sejam realizadas avaliações de aprendizagem para verificar meu domínio do conteúdo apresentado" não permaneceu na estrutura por não possuir carga fatoriais igual ou maior que 0,30. Tal item pertence ao fator "Regulação Externa da Aprendizagem" de Brant (2014), que define preferências do aluno em ter sua aprendizagem regulada pelo material didático, pelos professores, etc. Um possível motivo pelo qual o item não permaneceu no questionário nessa amostra é que a aplicação de avaliações não é uma preferência, pois ela ocorrerá inevitavelmente.

O item 4 "Realizar uma atividade paralela enquanto estudo, como ouvir música, assistir televisão, navegar na internet" inicialmente foi incluso no fator 1, denominado "Ambiente de Estudo". Porém, ao realizar o cálculo de confiabilidade, o valor do Alfa apresentou um valor negativo, e foi indicado que o mesmo teria seu valor alterado caso esse item fosse retirado do fator. Sendo assim, optou-se por sua exclusão do instrumento. Uma possível explicação para esse fato é que o item não trata de uma condição ambiental para o estudo, não demonstrando, portanto, relação com o fator em questão.

O primeiro fator, Ambiente de Estudo ( 2 itens, $\alpha=0,76$, cargas fatoriais entre 0,61 e 0,86). Os itens estão relacionados a definição de Zerbini (2007), que aponta como Estilos de Aprendizagem as preferências do aluno em relação ao ambiente no qual se realiza os estudos. 
O fator número 2, Regulação Externa (4 itens, $\alpha=0,63$, cargas fatoriais entre 0,39 e 0,85), apresentou itens pertencentes ao fator Regulação Externa de Brant (2014). Tal fator avalia, segundo a autora, as preferências relacionadas às estratégias e procedimentos instrucionais utilizados para orientação e controle do processo de aprendizagem.

Por fim, o fator 3, Interação Interpessoal ( 2 itens, $\alpha=0,40$, cargas fatoriais entre 0,31 e 0,84), possui itens relacionados à preferência do aluno em estudar e/ou realizar as atividades do curso sozinho ou com os demais alunos. Tal fator está presente no instrumento de Brant (2014) com o nome de Interação, e no instrumento de Salles (2007) com o nome de Preferência Interpessoal. Além disso, essa preferência é citada por Vermunt (1998), Zerbini (2007) e Brant (2014). Sendo assim, apesar de apresentar um índice de consistência interna não satisfatório, foi decidido manter o fator, incluir mais itens em uma próxima aplicação e reavaliar sua validade.

\section{Estratégias de Aprendizagem}

Martins (2012) realizou a primeira aplicação da escala em contexto de graduação a distância, após realizar importante modificações semânticas para adaptá-lo ao contexto de IES. Sendo assim, a autora recomendou novas aplicações do instrumento e sua consequente validação estatística.

$\mathrm{Na}$ literatura, alguns outros autores já mensuraram Estratégias de Aprendizagem, porém no nível fundamental (Boruchovitch \& Santos, 2004; Boruchovitch et al., 2006; Costa \& Boruchovitch, 2009). Ribeiro e Silva (2007) mensuraram no nível superior. Há também autores que focaram nas Estratégias de Aprendizagem usadas em ambientes de trabalho, tais como cursos técnicos profissionalizantes (Warr \& Downing, 2000), treinamentos a distância (Zerbini et al., 2005) e cursos de qualificação profissional a distância (Borges-Ferreira, 2005; Zerbini \& Abbad, 2008).

As análises descritivas mostram que os itens que obtiveram a maior média foram, em ordem crescente: 10) Busquei solucionar minhas dúvidas ao consultar as apostilas do curso $(\mathrm{M}=8,06 ; \mathrm{DP}=2,20) ; 16)$ Busquei sites relacionados ao conteúdo do curso para me ajudar a aprender (M=8,35; $\mathrm{DP}=2,25)$; e 27) Associei os conteúdos do curso aos meus conhecimentos anteriores $(\mathrm{M}=8,45 ; \mathrm{DP}=1,83)$. $\mathrm{O}$ primeiro e último item relatado pertencem ao fator de Estratégias Autorregulatórias e o segundo ao fator de Estratégias Comportamentais. Pode-se concluir que tais fatores são os mais utilizados pelos alunos. Destaca-se que, como dito anteriormente, o item 10, segundo Warr e Allan, é considerado busca de ajuda ao Material 
Didático, uma Estratégia Comportamental, e foi agrupado no fator de Estratégias Autorregulatórias de Martins (2012). O item 27 é considerado uma Estratégia Cognitiva de Elaboração, agrupado no fator Estratégias Cognitivas de Martins (2012). Uma explicação possível para que eles se agrupem em um único fator nesse estudo é a frequência com que foram usados pelos alunos, e provavelmente com um objetivo comum.

As análises exploratórias da escala não indicaram itens altamente correlacionados entre si. Foram obtidos quatro fatores de Estratégias de Aprendizagem, diferentes da estrutura empírica encontrada por Martins (2012), bem como de Zerbini e Abbad (2008). São eles: 1) Estratégias Autorregulatórias; 2) Controle da emoção; 3) Estratégias Cognitivas e 4) Estratégias comportamentais.

O primeiro fator, denominado Estratégias Autorregulatórias (12 itens, $\alpha=0,90$, cargas fatoriais entre 0,40 e 0,86) agrupou itens de Estratégias Autorregulatórias definidas por Warr e Allan (1998), dos tipos Controle da Motivação e Monitoramento da Compreensão. Além disso, agrupou alguns itens das Estratégias Cognitivas de Elaboração e de Estratégias Comportamentais de Busca de Ajuda ao Material Didático. Em relação ao instrumento de Martins (2012), os itens são pertencentes aos fatores Estratégias Autorregulatórias e Estratégias Cognitivas. Em relação ao estudo de Zerbini e Abbad (2008), os itens correspondentes ao presente fator estão distribuídos entre os fatores Elaboração, Monitoramento da Compreensão e Controle da Motivação. Nota-se que todos os itens desse fator, de alguma maneira, estão relacionados a esforços pessoais para facilitar a aprendizagem. Por isso, o nome do fator permaneceu Estratégias Autorregulatórias, pois parece que as estratégias de Elaboração são consideradas, por essa amostra, como um modo de autorregular a aprendizagem.

O segundo fator, Controle da Emoção (3 itens, $\alpha=0,81$, cargas fatoriais entre 0,60 e 0,78) agrupou itens referentes ao fator Controle da Emoção de Martins (2012) e de Zerbini e Abbad (2008). Da mesma maneira, os itens pertencentes a esse fator estão relacionados a definição de Controle da Emoção de Warr e Allan (1998). Nesse sentido, pode afirmar-se que a estrutura, bem como o conceito de Controle da Emoção foi validada nesse instrumento.

O fator de número 3, Estratégias Cognitivas ( 8 itens, $\alpha=0,81$, cargas fatoriais entre 0,43 e 0,80), apresentou itens pertencentes aos fatores de Ajuda Interpessoal e Estratégias Cognitivas de Martins (2012). Segundo a definição de Warr e Allan (1998), o fator agrupou Estratégias de Ajuda Interpessoal, Aplicação Prática, Repetição e Organização, sendo as duas primeiras Estratégias Comportamentais e as duas últimas Estratégias Cognitivas. Em relação ao estudo 
de Zerbini e Abbad (2008), os itens do presente fator estão representados nos fatores de Ajuda Interpessoal e Repetição e Organização. Nota-se, realizando uma análise dos itens, que por mais que alguns deles estejam relacionados a Estratégias Comportamentais, para os alunos da presente amostra tais Estratégias foram consideradas cognitivas no sentido de facilitação da Aprendizagem. Ou seja, tais Estratégias serviram de auxílio cognitivo para os alunos desta pesquisa. Sendo assim, o nome do fator permaneceu Estratégias Cognitivas.

Por fim, o fator 4, Estratégias Comportamentais ( 2 itens, $\alpha=0,81$, cargas fatoriais entre 0,60 e -0,67), apresentou itens anteriormente descritos no fator de Estratégias Cognitivas de Martins (2012), porém, de acordo com a definição de Warr e Allan (1998), seriam Estratégias Comportamentais de busca de ajuda no material didático, que em sua definição fala da obtenção de informações em documentos escritos, manuais de instruções, programas de computador e outras fontes que não envolvam contato social. Esse é o caso dos itens relatados nesse fator, que tratam da busca de ajuda em sites e fontes fora da internet para ajudar nos estudos. No estudo de Abbad e Zerbini (2008), tais itens estão representados no fator Busca de Ajuda no Material Didático. É importante ressaltar que Vermunt (1998) denomina essas atividades como Estilos de Aprendizagem. Segundo o autor, tais itens refletem a preferência por aprender por iniciativa pessoal, por meio de pesquisa. Tal preferência seria contrária a aprender/estudar com outros alunos. A questão que fica é que se isso seria um Estilo ou uma Estratégia de Aprendizagem. Uma possível solução para o problema seria a validação divergente dos instrumentos através da Análise Fatorial Exploratória, que não foi possível neste estudo devido ao número de participantes. A amostra não foi suficiente de acordo com o critério de Pasquali (2004) que fala de ao menos 10 participantes para cada variável do estudo.

\section{Análises complementares: ANOVA e Teste $t$}

A primeira análise realizada com o Teste $t$ refere-se a Evasão e o Uso de Estratégias e Estilos de Aprendizagem. Aqui cabe fazer uma ressalva às análises descritivas da questão relativa a possibilidade de abandono do curso respondida pelos alunos. Para realizar essa análise, foram utilizados os fatores do instrumento "Fatores relacionados à evasão e à persistência em EAD” de Umekawa (2014). Do total de 135 respondentes, 44 abandonariam o curso por algum motivo (32,6\%), e 91 não abandonaria (67,4\%). Ou seja, a maioria dos alunos da amostra não abandonaria o curso. 
Dentre os alunos que abandonariam, 59,13\% abandonaria por Características Exógenas ao Curso. Segundo Umekawa (2014), tais características apreciam o quanto variáveis ligadas à conciliação do curso com outras atividades de estudos, profissionais e compromissos familiares; à disponibilidade de tempo; e a problemas de saúde dificultaram a persistência do estudante no evento instrucional.

A porcentagem de $36,35 \%$ dos alunos que abandonariam o curso, o faria devido ao Desenho do Curso. Para Umekawa (2014), esse fator considera em que medida os aspectos relativos ao planejamento instrucional (objetivos propostos, planejamento e sequência de conteúdos, avaliações de aprendizagem, carga horária, linguagem empregada e complexidade do curso) contribuem para a saída/permanência do aluno do evento educativo.

Por fim, 4,52\% desses estudantes abandonariam o curso por características individuais, correspondendo ao fator Características do Aluno de Umekawa (2014), que se refere a quanto elementos concernentes às habilidades e atributos discentes (administrar o tempo de estudo, elaborar planos de estudo, respeitar e cumprir prazos, perseverar frente a contratempos e experiências prévias com os recursos tecnológicos) interferiram sobre a permanência no mesmo na ação educativa.

O instrumento utilizado pela autora tinha um último fator, denominado Suporte Tecnológico e de Tutoria, que avalia o quanto aspectos relacionados às competências demonstradas pelo tutor ao longo do curso; à acessibilidade dos materiais e o suporte institucional e social recebido pelo estudante; e às ferramentas virtuais de acesso dificultaram a permanência do aluno no curso. Porém, na presente amostra, nenhum aluno justificou seu possível abandono do curso por esses motivos.

De volta ao Teste $t$, foram avaliados o uso de Estratégias e Estilos de Aprendizagem pelos alunos que abandonariam o curso. Os resultados demonstraram que os alunos que não abandonariam o curso por algum motivo fizeram maior uso das Estratégias Autorregulatórias e Comportamentais, e apresentaram maiores Preferências Ambientais. Além disso, esses alunos eram em sua maioria do sexo feminino.

Outras conclusões retiradas do Teste $t$ são que os participantes do sexo Masculino utilizam com mais frequência as Estratégias de Aprendizagem de Controle da Emoção do que os participantes do sexo feminino; e que os alunos que possuem filhos valorizam mais os aspectos do ambiente no qual no qual realizam seus estudos.

Por fim, a ANOVA demonstrou que os participantes com renda de 2 a 3 salários mínimos preferem mais estudar com outros alunos do que os participantes que possuem renda de até 
um salário mínimo. Da mesma maneira, os participantes com renda de 4 a 5 salários mínimos também preferem mais estudar com outros alunos do que os alunos que possuem renda de até um salário mínimo.

\subsection{Discussões dos resultados da validação convergente dos instrumentos de Estratégias de Aprendizagem e Estilos de Aprendizagem e análise conceitual de Estilos de Aprendizagem.}

Através dos resultados obtidos na validação convergente dos instrumentos, foi cumprido parcialmente o objetivo geral da pesquisa, no sentido que foi realizada validade convergente dos instrumentos de Estratégias de Aprendizagem e Estilos de Aprendizagem, e foi proposta uma discussão conceitual sobre Estilos de Aprendizagem. Também foram cumpridos os seguintes objetivos específicos: (5) Realizar a validade convergente entre os instrumentos de Estratégias de Aprendizagem e Estilos de Aprendizagem, a fim de verificar as semelhanças e diferenças conceituais e metodológicas - referentes às medidas existentes e utilizadas; (6) Propor uma discussão conceitual sobre Estilos de Aprendizagem.

Dois itens do fator Estratégias Comportamentais (15. "Busquei outras fontes de pesquisa, fora da internet, relacionadas ao curso para me ajudar a aprender" e 16. "Busquei sites relacionados ao conteúdo do curso para me ajudar a aprender") foram considerados Estilos de Aprendizagem por Vermunt (1998). O autor considera que tais itens representam uma preferência por aprender por iniciativa própria, por meio de pesquisa. Isso seria o contrário de aprender/estudar com outros alunos. Porém, observando a validação convergente, o fator não se correlacionou de maneira significativa com o fator Interação Interpessoal, que trata do fato de estudar sozinho ou com outros alunos. Correlacionou-se, porém, com o fator Ambiente de Estudo, porém com um baixo índice de correlação. Ou seja, os resultados sugerem que tais itens não são considerados Estilos de Aprendizagem.

O fator Controle de Emoção também é considerado um Estilo de Aprendizagem para Vermunt (1998). O autor chama esse fator de Estilo Autorregulatório, que trata das preferências relacionadas ao controle das emoções durante o estudo, por exemplo: preferir ficar mais calmo ou mais agitado durante os estudos. Porém, esse fator não se correlacionou com nenhum fator de Estilos de Aprendizagem, o que sugere que tais itens não são considerados Estilos de Aprendizagem, não corroborando Vermunt.

No fator de Estratégias Cognitivas, o item 12 "Busquei auxílio do tutor para esclarecer minhas dúvidas sobre o conteúdo" é considerado um Estilo de Aprendizagem de Regulação 
Externa para Brant (2014). Isso pode ter sido um dos motivos pelos quais o fator apresentou uma correlação significativa com o fator de Regulação Externa. Os itens 13 “Busquei auxílio dos colegas nos fóruns para esclarecer minhas dúvidas" e 14 "Troquei mensagens com os colegas para esclarecer minhas dúvidas sobre o conteúdo do curso" tratam de interação do aluno com os demais alunos, o que é considerado por Brant (2014) e Vermunt (1998) um Estilo de Aprendizagem. Reflexo disso foi o alto índice de correlação do fator Estratégias Cognitivas com o fator Interação Interpessoal.

O item 10 do fator Estratégias Autorregulatórias "Busquei solucionar minhas dúvidas ao consultar as apostilas do curso" é considerado Estilo de Aprendizagem por Brant (2014), denominado de regulação externa da aprendizagem pelo material didático. $\mathrm{O}$ fator apresentou uma correlação significativa com o fator Regulação Externa do instrumento de Estilos de Aprendizagem, o que pode indicar uma convergência de conceitos. Não foi encontrada literatura relacionando os itens de Estratégias Autorregulatórias com os itens de Ambiente de Estudo, que explicasse assim a alta correlação apresentada entre os fatores.

A necessidade de construir um instrumento de Estilos de Aprendizagem em Ações Educacionais ofertadas a distância surgiu após a revisão de literatura, que apontou que não havia instrumento medindo tal construto nesse contexto dentro da POT. Os instrumentos encontrados na área medindo Estilos de Aprendizagem estão no contexto de Trabalho presencial (Salles, 2007) e a distância (Brant, 2014). Na área da Educação, muitos autores se dispuseram a medir o construto em variados contextos, porém, segundo Brant (2014), a grande maioria dispunha de problemas de validade e fidedignidade. O instrumento com melhores índices apontado pela autora foi o Index of Learning Styles de Vermunt (1998). Tal instrumento foi usado como orientador para construção realizada nessa pesquisa, juntamente com o proposto por Brant (2014), que trata do mesmo contexto que essa pesquisa.

Após a criação de alguns itens e a adaptação de alguns outros, os mesmos foram submetidos a Validação Semântica e por Juízes como descrito anteriormente. Finalizou-se essa etapa com um instrumento de 27 itens. Tal instrumento foi aplicado a amostra desta pesquisa.

Como já descrito anteriormente, foram percebidos erros de medida durante a realização da análise fatorial exploratória, o que sugeriu que alguns itens do instrumento não mediam o construto de Estilos de Aprendizagem. Sendo assim, a revisão item por item foi realizada, como demonstrada na seção 5.7. Notou-se também a necessidade de realizar uma 
análise conceitual do construto Estilos de Aprendizagem, também demonstrada na seção 5.7, pois antes de tudo, é necessário ter uma definição do construto que se pretende medir.

Durante a análise conceitual de Estilos de Aprendizagem, notou-se que alguns itens do instrumento utilizado no presente estudo necessitam serem reescritos nas próximas aplicações, para que possam deixar claro o que pretendem medir. $\mathrm{O}$ item 6) "...que os professores/tutores ofereçam exemplos de como se deve estudar" faz referência ao fator Regulação Externa da Aprendizagem de Brant (2014), e trata da regulação da aprendizagem pelos professores/tutores. Porém isso não ficou claro nessa escrita. Uma sugestão seria: “...que os professores/tutores me indiquem a melhor maneira de se estudar". Da mesma maneira, os itens 7) “...fazer minhas anotações em arquivos digitais no computador” e 26) “...ter o material impresso para ler" remetem a preferência por estudar no computador ou por material impresso. Porém, a maneira como foram escritos dá a impressão de que se tratam de Estratégias de Aprendizagem. Sendo assim, uma sugestão para os itens seria: “...realizar meus estudos usando o computador"; "estudar através do material impresso".

Os itens 5) “...estudar no período da noite”, 11) “...estudar no período da manhã” e 19) “...estudar no período da tarde" são considerados por Zerbini (2007) Estilos de Aprendizagem, indicando a preferência por horário de estudo. Por esse ser um curso a distância no qual a grande maioria dos participantes trabalha, muitos deles podem não ter a possibilidade de preferir um horário de estudo, uma vez que só podem estudar nos horários nos quais estão trabalhando. Sendo assim, os itens não foram aceitos na estrutura do instrumento, mas em outras amostras, com outras características e outros conceitos, tais itens devem ser novamente testados para verificar se realmente são Estilos de Aprendizagem.

Da mesma maneira, o instrumento final, com apenas 8 itens, deve receber novos itens, especialmente nos fatores Interação Interpessoal e Ambiente de Estudo que contam somente com dois itens cada um. Deve ser realizada a tentativa de inclusão de novos itens, para que seja verificado se o construto Estilos de Aprendizagem é contemplado somente por esses itens do instrumento ou pode haver outros itens que são abordados pela definição. É importante salientar que a inserção de novos itens deve respeitar a definição do construto.

A análise exaustiva da literatura demonstrou que o conceito de Estilos de Aprendizagem, é pouco estudado na área de POT, além de não possuir uma definição clara e seus instrumentos possuírem problemas relativos a validação. Sendo assim, foi necessária realizar a análise conceitual do construto, e explicitar sua definição. A validade convergente se fez necessária no sentido em que muitos autores tratam de Estilos de Aprendizagem e Estratégias de 
Aprendizagem de uma maneira conjunta, muitas vezes sem separar os dois conceitos, como é o caso de Vermunt (1998), que em seu instrumento Index of Learning Styles adiciona itens que são caracterizados como Estratégias de Aprendizagem. Uma outra análise necessária seria a validação divergente dos instrumentos através da Análise Fatorial Exploratória, que não foi possível neste estudo devido ao número de participantes. Como dito anteriormente, a amostra não suficiente de acordo com o critério de Pasquali (2004) que fala de ao menos 10 participantes para cada variável do estudo.

Considerando que a presente pesquisa está situada na área de conhecimento da POT, inicialmente foi estabelecida a referência da área para a definição de Estilos de Aprendizagem. Seguiu-se, assim, a definição de Warr e Allan (1998) e Zerbini (2007), que diz: "São as preferências do estudante referentes aos aspectos contextuais e as maneiras de estudo. Compreendem a preferência dos indivíduos por determinadas Estratégias de Aprendizagem e por aspectos do contexto em que esta ocorre". Essa definição foi selecionada por tratar dos Estilos de Aprendizagem no contexto de ações educacionais em IES ofertadas à distância. Enquanto as autoras Salles (2007) e Brant (2014) se focaram no contexto do trabalho, presencialmente e à distância, respectivamente. Porém, para realizar um estudo em profundidade, as definições das autoras, bem como a de Vermunt, que serviram de orientação para a construção do instrumento, também foram consideradas na análise conceitual e revisão do instrumento.

Após serem realizadas às analises descritivas e exploratórias, chegou-se a definição de Estilos de Aprendizagem como preferências do aluno relacionadas ao contexto e ambiente de estudo (luz, ruído, etc.), à maneira como sua aprendizagem é regulada (orientação dos professores/tutores em relação a maneira de estudar) e à sua interação interpessoal (estudar, fazer atividades e trocar informações com colegas do curso).

No próximo capítulo, finalizando o presente estudo, serão apresentadas as conclusões. 


\section{CAPÍTULO 7. CONCLUSÕES}

\section{Objetivo do capítulo}

O presente capítulo tem como objetivo concluir o estudo ao apresentar suas principais contribuições e limitações, e propor uma agenda de pesquisa.

Segundo Martins (2012), a área de avaliação de cursos no nível superior de ensino, especificamente, cursos de graduação ofertados a distância é bastante incipiente e carece de estudos sistemáticos, os quais proponham modelos multivariados de avaliação e façam uso de instrumentos de medida para cursos na modalidade EAD. Deve-se considerar que este é um campo de conhecimento ainda em fase de exploração, com poucas pesquisas e instrumentos disponíveis na literatura. Devido a esse fato foram realizadas análises exploratórias dos instrumentos utilizados nessa pesquisa. Além disso, recomenda-se que as escalas utilizadas nessa pesquisa sejam aplicadas em diferentes contextos de IES e amostras que estudem essencialmente a distância.

Ainda no contexto de EaD em IES, o estudo de Estilos de Aprendizagem é extremamente raro. Em outros contextos, destaca-se a falta de instrumentos fidedignos e válidos. Outro ponto é sua relação e diferenciação com o conceito de Estratégias de Aprendizagem. Devido a essas questões, o presente estudo realizou análise conceitual do construto de Estilos de Aprendizagem, construção e validação do instrumento de Estilos de Aprendizagem e sua validação convergente com o instrumento de Estratégias de Aprendizagem.

Após a realização das análises fatoriais exploratórias dos instrumentos, obteve-se escalas psicometricamente válidas e confiáveis em sua maioria. Os próximos passos devem incluir Análises Fatoriais Confirmatórias dos instrumentos de Estratégias de Aprendizagem e Estilos de Aprendizagem. O instrumento de Estilos de Aprendizagem deve receber novos itens e ter alguns dos seus atuais itens reescritos. Outra possibilidade são os procedimentos de análises de dados mais robustos e rigorosos para o teste de relações entre variáveis de TD\&E, como a modelagem por equação estrutural (MEE). Tais procedimentos são recomendados por Zerbini (2007) e Martins (2012) e auxiliam no desenvolvimento do campo teórico da área de avaliação instrucional.

Com um maior número de participantes, pode-se medir o quanto o uso de Estilos e Estratégias de Aprendizagem influenciam na Evasão em ações educacionais ofertadas a 
distância. Em relação a evasão, deve-se avançar na metodologia para a coleta de dados, a fim de que permita uma mensuração exatas do número de evadidos.

Os objetivos de pesquisa foram atingidos, e sobre os problemas de pesquisa levantados, pode-se dizer:

1) Quais as diferenças e semelhanças conceituais e metodológicas entre Estratégias de Aprendizagem e Estilos de Aprendizagem? Através das análises realizadas na literatura, podese concluir que a principal diferença conceitual entre Estilos de Aprendizagem e Estratégias de Aprendizagem é que a última é passível de treinamento, enquanto que o primeiro, por ser uma preferência individual, não pode ser treinado, mesmo que possa ser alterado de acordo com o contexto de estudo. A semelhança é que ambos são utilizados para facilitar o processo de aprendizagem. Um uso correto das Estratégias de Aprendizagem e a adaptação dos estudos segundo os Estilos de Aprendizagem de cada um, devem auxiliar na aprendizagem. Além disso, os conceitos dos dois construtos se convergem em alguns pontos, como foi demonstrado pela análise convergente. Cabe, no entanto, realizar mais estudos sobre o tema para ter certeza em que ponto os conceitos se convergem e divergem. Esse estudo foi somente um pontapé inicial. O próximo passo é a realização da Análise Fatorial Confirmatória dos instrumentos.

2) É possível propor uma definição conceitual mais adequada de Estilos de Aprendizagem, considerando o contexto de Ações Educacionais Ofertadas a Distância? Levando em consideração todas as análises realizadas, pode se concluir que Estilos de Aprendizagem são preferências do aluno relacionadas ao contexto e ambiente de estudo (luz, ruído, etc.), à maneira como sua aprendizagem é regulada (orientação dos professores/tutores em relação a maneira de estudar) e à sua interação interpessoal (estudar, fazer atividades e trocar informações com colegas do curso). Porém, ainda há um longo caminho a ser percorrido, especialmente no que se trata da sua correlação com o construto Estratégias de Aprendizagem. O presente estudo possibilitou o início de uma discussão acerca do tema.

3) Os Estilos de Aprendizagem e as Estratégias de Aprendizagem se relacionam com a possibilidade do aluno se evadir de um curso na modalidade EaD? Os testes $t$ realizados com os fatores dos instrumentos de Estilos de Aprendizagem e Estratégias de Aprendizagem relacionados com a possibilidade de Evasão do curso indicaram que os alunos que fizeram uso de certas Estratégias de Aprendizagem, tais como Estratégias Autorregulatórias e Estratégias Comportamentais, e demonstraram mais preferências em relação ao ambiente no 
qual realizam o estudo, ou seja, Estilos de Aprendizagem de Ambiente de Estudo tendem a não abandonar o curso.

Dentre as contribuições deste estudo, destacam-se: (1) Revisão de literatura sobre a variável "Estilos de Aprendizagem" nos campos de conhecimento da Psicologia e da Educação, a qual apoiou embasamento teórico do texto, contribuindo para o alcance dos resultados de pesquisa sobre a temática de interesse; (2) Construção de um instrumento de Estilos de Aprendizagem no contexto de ações educacionais ofertadas a distância em IES, baseado no campo teórico da POT; (3) Verificação de evidências de validade dos instrumentos de "Estratégias de Aprendizagem" de Martins (2012) e de "Estilos de Aprendizagem", que podem ser utilizados em futuras pesquisadas da área de avaliação de ações educacionais a distância, em O\&T e IES que ofertam cursos EAD; (4) Análise conceitual do construto de Estilos de Aprendizagem; (5) Análise convergente dos instrumentos de Estilos de Aprendizagem e Estratégias de Aprendizagem, colaborando com a análise conceitual do construto de Estilos de Aprendizagem, além de contribuir para a definição mais completa do construto de Estilos de Aprendizagem.

Quanto às limitações do estudo, pode-se citar:

1) Não utilização de métodos estatísticos mais robustos, tais como a Análise Fatorial Confirmatória e Modelagem de Equação Estrutural, sendo que essas duas últimas poderiam colaborar na testagem de modelos de predição, como por exemplo na influência dos Estilos e das Estratégias de Aprendizagem na Possibilidade de Evasão;

2) Impossibilidade de generalizar os resultados encontrados na presente pesquisa para outros contextos e participantes, pois foi avaliado apenas um curso, de apenas uma IES. Além disso, como não foi possível coletar dados sobre a população de alunos, não se pode afirmar se as características da amostra são semelhantes à da população;

3) Uso de apenas uma fonte de informação: os alunos do curso participante da IES avaliada - deve-se, em estudos futuros, incluir outros atores envolvidos nas ações educacionais, como os tutores;

4) Amostra, por mais que relativamente grande se comparada à população, ainda insuficiente para realizar outras análises necessárias, como a Análise Fatorial Exploratória conjunta entre os Instrumentos de Estratégias de Aprendizagem e Estilos de Aprendizagem, possibilitando uma validação convergente e divergente mais completa; 
5) Ainda sobre a amostra, o critério de 10 participantes por variável sugerido por Pasquali (2004) não foi cumprido no instrumento de Estratégias de Aprendizagem, o que pode diminuir a validade dos resultados.

6) Pergunta frágil metodologicamente para mensurar a Evasão, pois questionava somente se o aluno evadiria por algum motivo, mas não mensurou se o mesmo evadiu ou não;

7) Instrumento de Estilos de Aprendizagem pouco consistente, com pouco itens e necessitado de uma revisão e melhorias.

Os resultados obtidos trazem implicações práticas que referem ao uso das medidas de avaliação de cursos a distância em instituições de ensino e também em organizações de trabalho que oferecem ações educacionais EAD no que concerne às características dos alunos (Estilos e Estratégias de Aprendizagem). Tendo conhecimento a respeito do melhor método de mensuração dessas variáveis, pode-se compilar informações pertinentes ao aprimoramento do planejamento instrucional adotado e, consequentemente, dos efeitos produzidos. Segundo Martins (2012), o aperfeiçoamento de cursos na modalidade a distância contribui para que a mesma possa ser vista como uma alternativa educacional disponível, com aplicabilidade atestada por meio de pesquisas científicas. As pesquisas, segundo a autora, podem fornecer conhecimentos e discussões acerca dos elementos necessários para que a modalidade não caia no descrédito e esteja constantemente à revelia de preconceitos e comentários depreciativos sobre a sua qualidade e eficácia.

Diante dos resultados e das discussões promovidas no presente estudo, a seguinte agenda de pesquisa é proposta:

1) Aplicação dos instrumentos de medida utilizados nesta pesquisa em outros contextos e amostras, como por exemplo em organizações que ofereçam cursos à distância.

2) Realizar análises confirmatórias das estruturas empíricas utilizadas nesta pesquisa;

3) Testar por meio de modelagem por equação estrutural, diferentes relacionamentos entre variáveis, incluindo relação de mediação e moderação;

4) Aprofundar as discussões sobre Estilos de Aprendizagem em contextos de IES e EAD;

5) Realizar análise fatorial confirmatória entre os instrumentos de Estilos de Aprendizagem e Estratégias de Aprendizagem, complementando de forma consistente a validação divergente e convergente dos instrumentos;

6) Realizar modificações visando a complementação e melhoria do instrumento de Estilos de Aprendizagem, com inserção de novos itens e adaptação de alguns atuais; 
7) Mensurar a variável Evasão de maneira mais robusta, através da melhoria do método de coleta de dados;

8) Rever o instrumento de Estratégias de Aprendizagem, baseado na validação convergente com o instrumento de Estilos de Aprendizagem e na análise conceitual de Estilos de Aprendizagem.

O presente estudo pretendeu atender recomendações e agendas de pesquisas anteriormente propostas (Zerbini, 2007; Martins, 2012; Umekawa, 2014) e espera ter contribuído com a área de área de avaliação de cursos a distância, especialmente, em relação às características do aluno em contexto de IES. 


\section{REFERÊNCIAS}

Abbad, G. (1999). Um modelo integrado de avaliação de impacto de treinamento no trabalho. Tese Doutorado, Instituto de Psicologia, Universidade de Brasília.

Abbad, G. S., Carvalho, R. S. \& Zerbini, T. (2006). Evasão em curso via internet: explorando variáveis explicativas. Revista de administração de empresas eletrônica, 5(2), Art. 17, jul./dez.

Abbad, G., \& Meneses, P. P. M. (2004). Locus de controle: validação de uma escala em situação de treinamento. Estudos de Psicologia, 9(3), 441-450.

Abbad, G., Côrrea, V. P., \& Meneses, P. P. M. (2010). Avaliação de treinamentos a distância: relações entre Estratégias de Aprendizagem e satisfação com o treinamento. RAM - Revista de Administração Mackenzie, 11(2),43-67.

Abbad, G., Pantoja, M. J., \& Pilati, R. (2001). Avaliação de treinamento: o estado da arte e o futuro necessário. In Encontro anual da ANPAD, 25. Campinas: ANPAD.

Abbad, G., Zerbini, T., Carvalho, R. S. \& Meneses, P. P. M. (2006). Planejamento instrucional em TD\&E. In J. E. Borges-Andrade, G. Abbad, L. Mourão (Orgs.), Treinamento, desenvolvimento e educação em organizações e trabalho: fundamentos para a gestão de pessoas (pp. 289-321). Porto Alegre, RS: Artmed.

Abbad, G.; Zerbini, T. \& Souza, D. B. L.(2010). Panorama das pesquisas em Educação a Distância no Brasil. Estudos de Psicologia (UFRN), 15, 291-298.

Abbad, G.S. (2007). Educação a Distância: O Estado da Arte e o Futuro Necessário. In International Seminar on Distance Learning. Brasília.

Aguinis, H., \& Kraiger, K. (2009). Benefitis of training and development for individuals and teams, organizations, and society. Annual Review of Psychology, 60, 451-474

Almeida, O. C. S. (2007). Evasão em cursos a Distância: validação de instrumento, fatores influenciadores e cronologia da desistência. Dissertação de Mestrado, Instituto de Psicologia, Universidade de Brasília.

Altman, H., \& Arambasich, L. (1982). A Study of Locus of Control with Adult Students. Canadian Counsellor Conseiller Canadien, 16(2), 97-101.

Alves, L. (2011). Educação a distância: conceitos e história no Brasil e no mundo. Revista Brasileira de Aprendizagem Aberta e a Distância, 10, 83-92.

Amidani, C. (2004). Evasão no ensino superior a distância: o curso de licenciatura em matemática a distância da Universidade Federal Fluminense/CEDERJ - RJ. Dissertação de Mestrado. Faculdade de Educação, Universidade de Brasília, Brasília.

Anuário Brasileiro Estatístico de Educação Aberta e a Distância. Instituto Monitor. São Paulo: Autor, 2007. 
Appana, S. (2008). A Review of Benefits and Limitations of Online Learning in the Context of the Student, the Instructor and the Tenured Faculty. International Journal on E-Learning, $7(1), 5-22$.

Associação Brasileira de Educação a Distância (2012).

Battalio, J. (2009) Success in Distance Education: Do Learning Styles and Multiple Formats Matter? American Journal od Distance Education, 23(2), 71-87

Belloni, M. L. (1999). Educação a distância. Campinas: Autores Associados.

Beluce, A. C. \& Oliveira, K. L. (2012). Ambientes virtuais de aprendizagem: das estratégias de ensino às Estratégias de Aprendizagem. In IX ANPED SUL (pp. 1-14).

Berings, M. G. M. C., Poell R.F., \& Simons, P. R. J. (2005). Conceptualizing on-the-job learning styles. Human Resource Development Review, 4, 373-400.

Bjork, R. A.; Dunlosky, J.; \& Kornell, N. (2013). Self-Regulated Learning: Beliefs, Techniques, and Illusions. Annu. Rev. Psychol., 64, 417-44.

Borges-Andrade, J. E. (1982). Avaliação somativa de sistemas instrucionais: integração de três propostas. Tecnologia Educacional, 11(46), 29-39.

Borges-Andrade, J. E. (2006). Avaliação integrada e somativa em TD\&E. In J. E. BorgesAndrade, G. Abbad, L. Mourão (Orgs.). Treinamento, desenvolvimento e educação em organizações e trabalho: fundamentos para a gestão de pessoas (pp. 343-358). Porto Alegre: Artmed.

Brandão, H. P.; \& Borges-Andrade, J. E. (2011). Desenvolvimento e Validação de uma Escala de Estratégias de Aprendizagem no Trabalho. Psicologia: Reflexão e Crítica, 24(3), 448-457.

Brant, S. R. C. (2014). Estudo multinível de antecedentes do impacto no trabalho e da persistência/Evasão em treinamentos a distância. Tese de doutorado, Instituto de Psicologia, Universidade de Brasília.

Brauer, S. (2005). Avaliação de um Curso a Distância: Valor Instrumental do Treinamento, Barreiras Pessoais à Conclusão e Evasão. Instituto de Psicologia, Universidade de Brasília, Brasília.

Brown, T., Zoghi, M., Willians, B., Jaberzadeh, S., Roller, L.., Palermo, C., et al. (2009). Are learning style preferences oh health Science students predictive of their atitudes towards elearning? Australasian Journal of Educational Technology, 25(4), 524-543.

Brusilovsky, P., \& Peylo, C. (2003). Adaptative ans inteligente Web-based educational systems [Special Issue]. International Journal of Artificial Intelligence in Education, 13, 159172. 
Burke, L. A., \& Hutchins, H. M. (2007). Training transfer: an integrative literature review. Human Resource Development Review, 6(3), 263-297.

Borges-Ferreira, M. F. (2005). Avaliação de reações e aprendizagem em disciplinas de curso técnico profissionalizante oferecidas a distância. Dissertação de Mestrado, Instituto de Psicologia, Universidade de Brasília.

Boruchovitch, E., \& Santos, A. A. A. (2004). Escala de avaliação de estratégias de aprendizagem para crianças do ensino fundamental. Manuscrito não publicado, Universidade São Francisco, Bragança Paulista.

Boruchovitch, E., Santos, A. A. A., Costa, E. R., Neves, E. R. C., Cruvinel, M., Primi, R., \& Guimarães, S. E. R. (2006). A construção de uma escala de estratégias de aprendizagem para alunos do ensino fundamental. Psicologia: Teoria e Pesquisa, 22(3), 297-304.

Carswell, A. D., \& Venkatesh, V. (2002). Learner outcomes in an asynchronous distance education environment. International Journal of Human-Computer Studies, 56, 475-494.

Carvalho, R. S. \& Abbad, G. (2006). Avaliação de treinamento a distância: reação, suporte à transferência e impactos no trabalho. Revista de Administração Contemporânea, 10(1), 95116.

Castro, M. N. M. \& Ferreira, L. D. V. (2006). TD\&E a distância: múltiplas mídias e clientelas. In J. E. Borges-Andrade, G. Abbad, L. Mourão (Orgs.), Treinamento, desenvolvimento e educação em organizações e trabalho: fundamentos para a gestão de pessoas (pp. 322-339). Porto Alegre: Artmed.

Cheung, D. (2000). Evidence of a single second-order factor in student ratings of teaching effectiveness. Structural Equation Modeling, 7(3), 442-460.

Codes, A. L. M. (2005). Modelagem de equações estruturais: um método para análise de fenômenos complexos. Caderno $C R H, 18(45), 471-484$.

Coelho Jr., F. A. \& Borges-Andrade, J. E. (2008). Uso do conceito de aprendizagem em estudos relacionados ao trabalho e organizações. Paidéia, 18(40), 221-234.

Coelho, M. L. A. (2003). Formação continuada do docente universitário em cursos a distância via Internet: um estudo de caso. Monografia de Conclusão de Curso. Belo Horizonte: ABED.

Coll, C., Mauri, T. \& Onrubia, J. (2010). A incorporação das tecnologias da informação e da comunicação na educação - do projeto pedagógico às práticas de uso. In C. Coll \& C. Monereo (Orgs.). Psicologia da Educação virtual - Aprender e ensinar com as tecnologias da informação e da comunicação (pp. 66-93). Porto Alegre: Artmed.

Costa, E. R., \& Boruchovitch, E. (2009). As Estratégias de Aprendizagem e a produção de textos narrativos. Psicologia: Reflexão e Crítica, 22(2), 173-180.

Dean, A., \& Webster, L. (2000). Simulations in distance education-progress towards an evaluation instrument. Distance Education, 21(2), 344-360. 
Döös, M. \& Wilhelmson, L. (2011). Collective learning: interaction and a shared action arena, Journal of Workplace Learning, 23(8), 487-500.

Eboli, M. (2004). Educação Corporativa no Brasil: Mitos e Verdades. São Paulo: Editora Gente.

Favero, R. V. M., \& Franco, S. R. K. (2006). Um estudo sobre a permanência e a Evasão na educação a distância. CINTED-UFRGS, 4(2).

Felder, R. M. \& Silverman, L. K. (1988). Learning and teaching styles in engineering education. Engineering Education, 78(7), 674-681.

Freeze, R. D., Alshare, K. A., Lane, P. L., \& Wen, H. J. (2010). Is success model in e-learning context based on students' perceptions. Journal of Information Systems Education, 21(2), 173184.

Gomes, M. A M. \& Boruchovitch, E. (2005). Desempenho no jogo, Estratégias de Aprendizagem e compreensão na leitura. Psicologia Teoria e Pesquisa, 21(3), 319-326.

Gondin, S. M. G. \& Silva, N. (2004). Motivação no Trabalho. In J. C. Zanellie, J. E. BorgesAndrade \& A. V. B. Bastos (Orgs.), Psicologia, organizações e trabalho no Brasil (pp. 145176). Porto Alegre: Artmed.

Hair, J. F., Anderson, R. L., Tatham, R. L. \& Black, W. C. (2005). Análise Multivariada de dados (5a ed.). Porto Alegre: Bookman.

Henke, H. \& Russum, J. (2000). Factors Influencing Attrition Rates in a Corporate Distance Education Program. Education at a Distance Journal, 14(11).

Holder, B. (2007). An investigation of hope, academics, environment, and motivation as predictors of persistence in higher education online programs. Internet and Higher Education, $10,245-260$.

Holman, D., Epitropaki, O., \& Fernie, S. (2001). Understanding learning strategies in the workplace: a factor analytic investigation. Journal of Occupational and Organizational Psychology, 74, 675-681.

Honey, P. \& Mumford, A. (2000). The Learning Styles Questionnaire: 80 Item Version. Maidenhead, Berkshire, UK: Peter Honey Publications.

Iglesias, M; \& Salgado, J. F. (2012). Effectiveness of Occupational Training Through Videoconferencing: Comparison with Classroom Training and Individual Differences. Revista de Psicología del Trabajo y de las Organizaciones, 28(3), 183-188

Johnson, R. D., Gueutal, H., \& Falbe, C. M. (2009). Technology, trainees, metacognitive activity and e-learning effectiveness. Journal of Managerial Psychology, 24(6), 545-566. 
Joly, M. C. R. A.; Cantalice, L.M. \& Vendramini, C. M. M. (2004). Evidências de validade de uma escala de estratégias de leitura para universitários. Interação em Psicologia, 8, 261-270.

Kearley, K.; Moore, M. G. (2005) Distance education a system view. 2. ed. Belmont, CA, USA: Thomson Wadsworth.

Kirkpatrick, D. L. (1976). Evaluation of training. In R. L. Craig (Org.), Training and Development Handbook (pp. 18.1-18.27). New York: McGraw-Hill.

Klein, B., McCall, L., Austin, D. \& Piterman, L. (2007). A psychometric evaluation of the Learning Styles Questionnaire: 40-tem version. British Journal Of Educational Technology, $38(1), 23-32$

Kolb, A. Y., and D. A. Kolb. 2005. The Kolb Learning style inventory-version 3.1: 205 technical specifications. Boston, MA: Hay Resources Direct.

Kolb, D. A. (1985). Learning style inventory: self-scoring inventory and interpretation booklet. Boston, MA: McBer and Company.

Lee, Y., Tseng, S., Liu, F., \& Liu, S. (2007). Antecedents of learner satisfaction toward elearning. Journal of American Academy of Business, 11(2), 161-168.

Litwin, E. (2001). Educação a Distância: temas para o debate de uma nova agenda educativa. Porto Alegre: Artmed Editora.

Lu, H. P., \& Chiou, M. J. (2010). The impact of individual differences on e-learning system satisfaction: a contingency approach. British Journal of Educational Technology, 41(2), 307323.

Machado, O. A. (2005). Evasão de alunos de cursos superiores: fatores motivacionais e de contexto. Dissertação de Mestrado em Educação, Universidade Estadual de Londrina, Londrina.

Martins, L. B. (2012). Aprendizagem em ações educacionais a distância: fatores influentes no desempenho acadêmico de universitário. Dissertação de Mestrado, Faculdade de Filosofia, Ciências e Letras de Ribeirão Preto, Universidade de São Paulo, São Paulo.

Martins, L. B. (2015). Impacto do treinamento no trabalho: determinantes individuais e contextuais em cursos a distância. Proforma da Tese apresentada para o Exame de Qualificação, Faculdade de Filosofia, Ciências e Letras de Ribeirão Preto, Universidade de São Paulo, São Paulo.

Meneses, P. P. M., Abbad, G, Zerbini, T., \& Lacerda, E. (2006). Medidas de características da clientela em avaliação de TD\&E. In J. E. Borges-Andrade, G. Abbad, L. Mourão (Orgs.). Treinamento, desenvolvimento e educação em organizações e trabalho: fundamentos para a gestão de pessoas (pp. 422 - 442). Porto Alegre: Artmed.

Moore, M. G., \& Kearsley, G. (1996). Distance education. A systems view. Belmont: Wadsworth Publishing Company. 
Morales Vallejo, P. M.; Sanz, B. U.; Blanco, A. (2003) Cuadernos de Estadística, Construcción de escalas de actitudes tipo Likert. Madrid: Editorial La Muralla S.A.

Morris, L. V., Finnegan, C., \& Wu, S. (2005). Tracking student behavior, persistence, and achievement in online courses. The Internet and Higher Education, 8(3), 221-231.

Nastanski, M., Slick, T. (2008). Learning Styles and the online classroom: implications for business students. Journal of College Teaching \& Learning, 5(10), 29-50.

Ngoma, P. S., Simwanza, A., \& Makukna, C. K. (2004). Investigating the Drop Out Problem Amongst University Extension Studies Learners in Zambia. Third Pan- Commonwealth Forum on Open Learning, Dunedin, New Zealand. Acessado em 12 de setembro de 2011 em: http://www.col.org/pcf3/Papers/PDFs/Ngoma_Simwanza_Makunka.pdf.

Nichols, D. P. (1999) My Coefficient $\alpha$ is Negative, SPSS Keywords, Number 68. Disponível em <http://www.ats.ucla.edu/STAT/SPSS/library/negalfa.htm> acessado em 04/08/2006.

Oliveira, K. L., Boruchovitch, E., \& Santos, A. A. A. (2009). Estratégias de Aprendizagem e desempenho acadêmico: evidências de validade. Psicologia: teoria e pesquisa, 25(4), 531536.

Oliveira, K. L.; Boruchovitch, E.; \& Santos, A. A. A. (2011). Estratégias de Aprendizagem no ensino fundamental:análise por gênero, série escolar e idade. Psico, 42(1), 98-105.

Pacheco, A. S. V.; Rissi, M.; Nakayama, M. K.; Silveira, R. A.; \& Spanhol, F. J. (2010). A desistência de estudantes de um curso na modalidade a distância voltado para adolescentes. Revista Novas Tecnologias na Educação, 8(3).

Palloff, R. M., \& Pratt, K. (2004). O aluno virtual: um guia para trabalhar com alunos online. Porto Alegre: Artmed.

Pantoja, M. J. (2004). Estratégias de Aprendizagem no trabalho e percepções de suporte à aprendizagem - uma análise multinível. Tese de Doutorado, Instituto de Psicologia, Universidade de Brasília.

Pantoja, M. J., \& Borges-Andrade, J. E. (2009). Estratégias de Aprendizagem no trabalho em diferentes ocupações profissionais. RAC-Eletrônica, 3(1), 41-62.

Parker, A. (1995). Distance Education Attrition. International Journal of Educational Telecommunications, 1(4), 389-406.

Pasquali, L. (1998). Princípios de elaboração de escalas psicológicas. Revista de Psiquiatria Clínica, 25(5), 206-213

Pasquali, L. (2004). Análise fatorial para pesquisadores. Petrópolis: Vozes.

Pereira, E. W. (2003). Educação a Distância: Concepção e Desenvolvimento. Revista da Faculdade de Educação, 9(17), 197-212. 
Pierrakeas, C., Xenos, M., Panagiotakopoulos, C., \& Vergidis, D. A. (2004). Comparative Study of Dropout Rates and Causes for Two Different Distance Education Courses. International Review of Research in Open and Distance Learning, 5(2).

Pilati, R., \& Borges-Andrade, J. E. (2006). Construção de medidas e delineamentos em avaliação de TD\&E. In J. E. Borges-Andrade, G. Abbad, L. Mourão \& colaboradores. Treinamento, desenvolvimento e educação em organizações e trabalho: fundamentos para a gestão de pessoas (pp. 359-384). Porto Alegre: Artmed.

Raymond, A. N., Clarke, A. D. M. \& Klein, H. J. (2014). Learning in the Twenty-FirstCentury Workplace. Annu. Rev. Organ. Psychol. Organ. Behav, 1, 4.1-4.31.

Reis, F. L. (2009). Do ensino presencial ao ensino a distância no contexto universitário na Península Ibérica. Revista Brasileira de Aprendizagem Aberta e a Distância, 8, 1-28.

Ribeiro, I. S., \& Silva, C. F. (2007). Auto-regulação: diferenças em função do ano e área em alunos universitários. Psicologia: Teoria e Pesquisa, 23(4), 443-448.

Richardson, J. T. E. (2011). Approaches to studying, conceptions of learning and learning styles in higher education. Learning and Individual Diferences, 21,

Sahin, I., \& Shelley, M. (2008). Considering students' perceptions: the distance education student satisfaction model. Educational Technology \& Society, 11(3), 216-223.

Salas, E., \& Cannon-Bowers, J. A. (2001). The science of training: a decade of progress. Annual Review of Psychology, 52, 471-499.

Salas, E., Tannenbaum, S. I., Kraiger, K., \& Smith-Jentsch, K. A. (2012). The Science of Training and Development in Organizations: What Matters in Practice. Psychological Science in the Public Interest, 13(2) 74-101.

Sales, P. A. O. (2009). Evasão em Cursos a Distância: Motivos Relacionados às Características do Curso, do Aluno e do Contexto de Estudo. Dissertação de Mestrado, Instituto de Psicologia, Universidade de Brasília, Brasília.

Salles, T. J. (2007). Estilos de Aprendizagem no Trabalho: Análise e Construção de Medidas. Dissertação de Mestrado, Instituto de Psicologia, Universidade de Brasília, Brasília.

Sánchez, M.; Sarabia, F. J. (1999) Validez y fiabilidad de escalas. In: Sarabia, F. J. (Organizador), Metodologia para la investigación em marketing y dirección de empresas. Editora Pirâmide, Madrid.

Santos, A. A. A., Boruchovitch, E., Primi, R., Zenorini, R. P. C., \& Bueno, J. M. H (2004). Escala de avaliação de Estratégias de Aprendizagem para universitários (EAP-U): aplicação do Modelo de Rasch de créditos parciais. Braga-PT: Psicologia: Teoria, Investigação e Prática, 9(2), 227-242. 
Shin, N. \& Kim, J. (1999). An exploratory of learner progress and drop-out in Korea National Open University. Distance Education, 20(3), 81-95.

Silva, D. R., \& Tomaz, J. B. C. (2006). Porque a Evasão? Escola de Saúde Pública do Ceará. Fevereiro.

Silva, G. O. L. (2011). Construção e Evidências de Validade e Precisão de Escala de Estilos de Aprendizagem em Universitários. Tese de Douturado, Centro de Ciências da Vida, Pontífica Universidade Católica (PUC), Campinas.

Silva, R. P. A., Macêdo, L. C. B., \& Silva, I. L. R. (2013) Avaliação das características psicométricas dos questionários utilizados nos periódicos da área contábil: um estudo longitudinal compreendido no período 2003-2012. XX Congresso Brasileiro de Custos Uberlândia, MG, Brasil. Disponível em: http://anaiscbc.emnuvens.com.br/anais/article/viewFile/124/124. Acesso em 28/12/2015.

Silva, L. L. V. (2012). Estilos e Estratégias de Aprendizagem de Estudantes Universitários. Dissertação de Mestrado, Instituto de Psicologia, Universidade de São Paulo (USP), São Paulo.

Sonnentag, S.; Niesse, C.; \& Ohly, S. (2004). Learning at work: training and development. In C. L. Cooper, \& I. T. Robertson (Eds), International Review of industrial and organizational psychology, (pp. 249-289). London: John Wiley and Sons.

Souza, L. F. N. I. (2010). Estratégias de Aprendizagem e fatores motivacionais relacionados. Educar, 36, 95-107.

Tabachnick, B. G., \& Fidell, L.S. (2007). Using multivariate statistics. New York: HarperCollins College Publishers.

Tannenbaum, S. I., \& Yukl, G. (1992). Training and development in work organizations. Annual Review of Psychology, 43, 399-441.

Testa, M. G. \& Luciano, E. M. (2010). A influência da autorregulação dos recursos de aprendizagem na efetividade dos cursos desenvolvidos em ambientes virtuais de aprendizagem na Internet. Revista Eletrônica de Administração, 16(2), 176-208.

Tucho, A. E. (2000). Factors Influencing the Successful Completion of the General Educational Development (GED) Program at the Community College of Philadelphia (CCP) as Perceived by the GED students. EdD, Temple University.

Umekawa, E. E. R. (2014). Preditores de fatores relacionados à Evasão e à persistência discente em ações educacionais a distância. Dissertação de Mestrado, Faculdade de Filosofia, Ciências e Letras de Ribeirão Preto, Universidade de São Paulo, São Paulo.

Varanda, R. C., Zerbini, T., \& Abbad, A. (2010). Construção e Validação da Escala de Reações à Interface Gráfica para Cursos de Educação a Distância. Psicologia: Teoria e Pesquisa, 26(2), 371-380. 
Vargas, M. R. M. \& Abbad, G. S. (2006). Bases Conceituais em Treinamento, Desenvolvimento e Educação (TD\&E). In J. E. Borges-Andrade, G. Abbad, L. Mourão (Orgs.), Treinamento, desenvolvimento e educação em organizações e trabalho: fundamentos para a gestão de pessoas (pp. 137-158). Porto Alegre: Artmed.

Vargas, M. R. M. (2004). Barreiras à implantação de programas de educação e treinamento a distância. Tese de Doutorado. Universidade de Brasília. Brasília.

Vermunt, J. D. (1998). The regulation of constructive learning processes. British Journal of Education Psychology, 68, 149-171.

Vermunt, J. D. (2005). Relations between student learrning patterns and personal and contextual factors and academic performance. Higher education, 49 (3), 205-234.

Walter, A. M. (2006). Variáveis Preditoras de Evasão em Cursos a Distância. Dissertação de Mestrado, Universidade de Brasília, Brasília.

Walter, A. M. (2008). Variáveis Preditoras de Evasão em Dois Cursos a Distância. In XXXII Encontro da ANPAD. Rio de Janeiro.

Wang, G., Foucar-Szocki, D., Griffin, O., O’Connor, C. \& Sceiford, E. (2003). Departure, Abandonment, and Dropout of E-learning: Dilemma and Solutions. James Madison University.

Warr, P., \& Allan, C. (1998). Learning strategies and occupational training. Internacional Review of Industrial and Organizational Psychology, 13, 83-121.

Warr, P., \& Bunce D. (1995). Trainee characteristics and outcomes of open learning. Personnel Psychology. 48, 347-375.

Warr, P., \& Downing, J. (2000). Learning strategies, learning anxiety and knowledge acquisition. British Journal Psychology, 91, 311-333.

Xenos, M., Pierrakeas, C. \& Pintelas, P. (2002). A survey on student dropout rates and dropout causes concerning the students in the Course of Informatics of the Hellenic Open University. Computers \& Education, 39, 361-377.

Yukselturk, E. \& Inan, F. A. (2006). Examining the Factors Affecting Student Dropout in an Online Learning Environment. Turkish Online Journal of Distance Education, 7(2).

Zerbini, T. \& Abbad, G. (2008). Estratégias de Aprendizagem em Curso a Distância: Validação de uma Escala. Psico-USF, 13(2), 177-187.

Zerbini, T. \& Abbad, G. (2010). Aprendizagem induzida pela instrução em contexto de organizações e trabalho: uma análise crítica da literatura. Cadernos de Psicologia Social do Trabalho, 13(2), 177-193. 
Zerbini, T. (2007). Avaliação da transferência de treinamento em curso a distância. Tese de Doutorado, Instituto de Psicologia, Universidade de Brasília.

Zerbini, T., \& Abbad, G. (2005). Impacto de treinamento no trabalho via internet. Revista de Administração de Empresas - RAE- eletrônica, 4(2).

Zerbini, T., Carvalho, R. S., \& Abbad, G. (2005). Treinamento a distância via internet: construção e validação de escala de Estratégias de Aprendizagem [CD-Rom]. Em Associação Nacional dos Programas de Pós-Graduação em Administração (Org.). Anais do XXIX ENANPAD. Brasília: ANPAD.

Zerbini, T., Coelho, F. A., Abbad, G. S., Mourão, L., Alvim, S., \& Loiola, E. (2012). Transferência de treinamento e impacto do treinamento em profundidade. In G. S. Abbad, L. Mourão, P. P. M. Meneses, T. Zerbini, J. E. Borges-Andrade, R. Vilas-Boas (Orgs.). Medidas de avaliação em treinamento, desenvolvimento e educação: ferramentas para gestão de pessoas (pp. 127-144). Porto Alegre: Artmed.

Zimmerman, B. J., \& Bandura, A. (1994). Impact of self-regulatory influences on writing course attainment. American Educational Research Journal, 31, 845-862. 


\section{ANEXO A: QUESTIONÁRIO SOCIODEMOGRÁFICO}

\begin{tabular}{|c|c|}
\hline \multicolumn{2}{|c|}{ QUESTIONÁRIO SOCIODEMOGRÁFICO } \\
\hline Sexo & $\begin{array}{l}\square \text { Feminino } \\
\square \text { Masculino }\end{array}$ \\
\hline \multicolumn{2}{|l|}{ Idade } \\
\hline Estado civil & $\begin{array}{l}\square \text { Solteiro } \\
\square \text { Casado } \\
\square \text { Amasiado } \\
\square \text { Divorciado } \\
\square \text { Viúvo } \\
\square \text { Outro }\end{array}$ \\
\hline Composição familiar & $\begin{array}{l}\square \text { Possui filhos } \\
\square \text { Não possui filhos }\end{array}$ \\
\hline Se possui filhos, informe quantos & $\begin{array}{l}\square \\
\square \\
\square \\
\square \\
\square \\
\square \\
\square \\
\square \text { mais de } 5 \\
\end{array}$ \\
\hline $\begin{array}{l}\text { Escolaridade (informe o grau mais alto de } \\
\text { escolaridade que você possui) }\end{array}$ & $\begin{array}{l}\square \text { Ensino Médio Completo } \\
\square \text { Superior Incompleto } \\
\square \text { Superior Completo } \\
\square \text { Pós Graduação }\end{array}$ \\
\hline \multicolumn{2}{|l|}{ Profissão/Ocupação atual } \\
\hline Renda (salários mínimos) & $\begin{array}{l}\square \text { até } 1 \\
\square 2-3 \\
\square 4-5 \\
\square \text { 6-7 } \\
\square 7 \text { ou mais }\end{array}$ \\
\hline $\begin{array}{l}\text { Experiência anterior no uso da internet } \\
\text { (Você era habituado ao uso da internet antes do } \\
\text { ingresso no curso à distância?) }\end{array}$ & $\square$ Sim \\
\hline Você abandonaria o curso por algum motivo? & $\begin{array}{l}\square \text { Sim } \\
\square \text { Não }\end{array}$ \\
\hline \multicolumn{2}{|l|}{$\begin{array}{l}\text { Se você respondeu sim à questão anterior, } \\
\text { informe os motivos pelos os quais você } \\
\text { abandonaria o curso. }\end{array}$} \\
\hline Código do aluno na Universidade & \\
\hline
\end{tabular}




\section{ANEXO B: TERMO DE CONSENTIMENTO LIVRE E ESCLARECIDO (TCLE)}

Prezado participante:

Convido-o a participar voluntariamente na pesquisa intitulada Impacto das estratégias e dos estilos de aprendizagem na evasão em ações educacionais ofertadas a distância. A pesquisa faz parte do meu projeto de mestrado do curso de Pós-graduação em Psicologia da Faculdade de Filosofia, Ciências e Letras de Ribeirão Preto - Universidade de São Paulo (FFCLRP-USP).

O objetivo deste estudo é propor e testar um modelo de avaliação de ações educacionais ofertadas presencialmente. Para tal, preciso de sua colaboração para poder obter as informações necessárias. A coleta de dados será realizada das seguintes formas: a) presencialmente, com a realização de entrevista individual com duração de 30 a 60 minutos; b) presencialmente, com realização de entrevista individual de aproximadamente 30 minutos; c) à distância, através do envio de questionários digitalizados via e-mail, tendo respeitados os aspectos éticos envolvidos.

Como forma de sigilo, seu nome não será utilizado em qualquer fase da pesquisa, garantindo o seu anonimato. Além disso, outras informações são relevantes, a saber: não lhe será cobrado nada, não haverá gastos nem riscos na sua participação neste estudo, não estão previstos ressarcimentos ou indenizações, e não haverá benefícios imediatos na sua participação. Os resultados obtidos contribuirão com os estudos sobre avaliação de treinamento na temática da efetividade de treinamentos em ambientes corporativos.

Registro que sua participação é voluntária e que você poderá se recusar a participar da pesquisa, retirar seu consentimento, ou ainda descontinuar sua participação a qualquer momento.

Desde já agradeço sua atenção e colaboração. Coloco-me à disposição para maiores informações pelo telefone (16) 98199-8519 ou pelo e-mail raissa.nmoraes@gmail.com. Em caso de dúvida(s) e outros esclarecimentos sobre a pesquisa você também poderá entrar em contato com a Prof ${ }^{a}$. Dr ${ }^{\mathrm{a}}$. Thaís Zerbini, responsável pela orientação deste projeto no telefone (16) 3602-4687 ou pelo e-mail thaiszerbini@ffclrp.usp.br.

Confirmo que Raíssa Bárbara Nunes Moraes me explicou os objetivos desta pesquisa, bem como a forma de participação. As alternativas para a minha participação também foram discutidas. Eu, compreendi este termo de consentimento livre e esclarecido, portanto, concordo em dar meu consentimento para participar como voluntário desta pesquisa.

Assinatura do Participante e Data

Assinatura do Pesquisador e Data 
Para APRENDER em cursos de ensino superior à distância, eu PREFIRO....

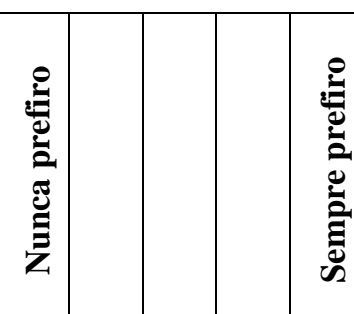

1) ....ser crítico em relação às interpretações de especialistas.

2) ...precisar processar uma pequena quantidade de matéria.

3) ...fazer cursos que atendam meus interesses pessoais.

4) ...fazer cursos que me enriqueçam financeiramente.

5) ...cursos que sejam um passatempo para mim.

6) ...fazer qualquer curso, pois gosto de estudar.

7) ... cursos que me garantem um diploma.

8) ...cursos nos quais eu consiga passar nas provas.

9) ...cursos que sejam desafiadores.

10) ...cursos que me possibilitem descobrir minhas próprias qualidades e limitações.

11) ...cursos que desenvolvam minhas habilidades profissionais.

12) ...cursos que sejam adequados às minhas capacidades de estudo.

13) ...cursos que me tragam benefícios apesar das dificuldades a serem encontradas no caminho.

14) ...abordar os problemas apresentados em aula ou no material de apoio de muitos ângulos diferentes, incluindo novos aspectos para mim.

15) ... receber instruções precisas sobre as atividades a serem realizadas no curso.

16) ...que os instrutores expliquem claramente o que é importante para que eu tome conhecimento.

17) ...que tenham testes para verificar se eu dominei todo o assunto.

18) ....receber informações que possam me ser úteis.

19) ...adquirir conhecimentos que sejam úteis para resolução de problemas práticos.

20) ...cursos que tenham estratégias motivacionais consistentes.

21) ...que os tutores me sirvam de exemplo na minha maneira de estudar.

22) ...que o material didático estimule meus estudos.

23) ...me preparar para os exames juntamente com outros alunos..

24) ...participar das atividades de interação virtual (fóruns, bate-papo) para discutir os assuntos com os outros estudantes.

25) ...realizar meus estudos em lugares bem iluminados.

26) ...estudar em ambientes com poucos ruídos.

27) ...ouvir música enquanto estudo. 
Para APRENDER em cursos à distância, eu PREFIRO....

1) ....ser crítico em relação às discussões apresentadas pelos professores/tutores.

2) ...estudar uma pequena quantidade de conteúdo por vez.

3) ...cursos que atendam meus interesses profissionais.

4) ...realizar uma atividade paralela enquanto estudo, como ouvir música, assistir televisão, navegar na internet.

5) ...estudar no período da noite.

6) ...que os professores/tutores ofereçam exemplos de como se deve estudar.

7) ...fazer minhas anotações em arquivos digitais no computador.

8) ...que o material didático facilite meus estudos.

9) ...cursos desafiadores.

10) ... estudar juntamente com outros alunos.

11) ...estudar no período da manhã.

12) ...participar das atividades de interação virtual (fóruns, bate-papo) para discutir os conteúdos com os outros estudantes.

13) ...receber instruções detalhadas sobre as atividades a serem realizadas no curso.

14) ...ser crítico em relação ao conteúdo apresentado no material didático.

15) ...que os professores/tutores expliquem claramente o que é importante estudar para alcançar os objetivos propostos no curso.

16) ...avaliar sozinho meu domínio sobre o conteúdo apresentado.

17) ...adquirir conhecimentos que sejam úteis para resolução de problemas práticos.

18) ...cursos que me garantam um diploma/título.

19) ...estudar no período da tarde.

20) ...realizar meus estudos em lugares bem iluminados.

21) ...estudar em ambientes com pouco barulho.

22) ...decidir sozinho o que é importante estudar para alcançar os objetivos propostos no curso.

23) ...realizar individualmente as tarefas.

24) ...que sejam realizadas avaliações de aprendizagem para verificar meu domínio do conteúdo apresentado.

25) ...cursos que auxiliem a descoberta de minhas qualidades e limitações como aprendiz.

26) ...ter o material impresso para ler.

27) ...ser lembrado sobre os prazos de entrega das atividades do curso. 
ANEXO E - INSTRUMENTO DE MEDIDAS DE ESTILOS DE APRENDIZAGEM EM CONTEXTO DE EAD EM IES APÓS VALIDAÇÃO ESTATÍSTICA

\begin{tabular}{|c|c|c|c|c|c|}
\hline Para APRENDER em cursos à distância, eu PREFIRO.... & 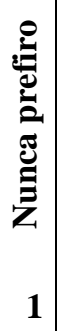 & 2 & 3 & 4 & 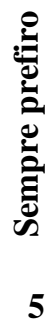 \\
\hline \multicolumn{6}{|l|}{ Interação Interpressoal } \\
\hline \multicolumn{6}{|l|}{ 10. Estudar juntamente com outros alunos. } \\
\hline \multicolumn{6}{|l|}{$\begin{array}{l}\text { 12. Participar das atividades de interação virtual (fóruns, bate-papo) para discutir os } \\
\text { conteúdos com os outros estudantes. }\end{array}$} \\
\hline \multicolumn{6}{|l|}{ Regulação Externa da Aprendizagem } \\
\hline \multicolumn{6}{|l|}{ 13. Receber instruções detalhadas sobre as atividades a serem realizadas no curso. } \\
\hline \multicolumn{6}{|l|}{$\begin{array}{l}\text { 15. Que os professores/tutores expliquem claramente o que é importante estudar para } \\
\text { alcançar os objetivos propostos no curso. }\end{array}$} \\
\hline \multicolumn{6}{|l|}{ 25. Ter o material impresso para ler. } \\
\hline \multicolumn{6}{|l|}{ 26. Ser lembrado sobre os prazos de entrega das atividades do curso. } \\
\hline \multicolumn{6}{|l|}{ Preferências Ambientais } \\
\hline 20. Realizar meus estudos em lugares bem iluminados. & & & & & \\
\hline 21. Estudar em ambientes com pouco barulho. & & & & & \\
\hline
\end{tabular}




\section{ANEXO F - QUESTIONÁRIO DE ESTRATÉGIAS DE APRENDIZAGEM APÓS VALIDAÇÃO ESTATÍSTICA}

Para responder às próximas questões, pense nos comportamentos utilizados por você durante o curso. A escala abaixo varia de 0 (nunca) a 10 (sempre). Leia atentamente os itens listados e escolha o ponto da escala $(0,1,2,3,4,5,6,7,8,9$ ou 10) que melhor representa a frequência com que você se comportou da maneira descrita em cada item. Registre sua resposta à direita de cada item com o número escolhido. Por favor, não deixe questões em branco

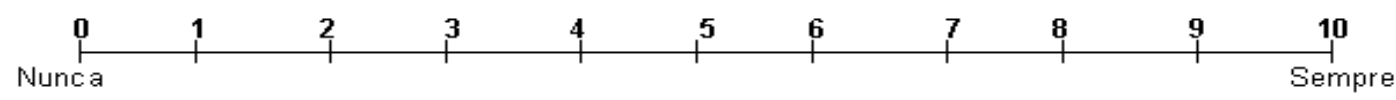

\begin{tabular}{|c|c|}
\hline Item & Nota \\
\hline \multicolumn{2}{|l|}{ Estratégias Autorregulatórias } \\
\hline 5. Esforcei-me mais quando percebi que estava perdendo a concentração. & \\
\hline 6. Forcei-me a manter a atenção nos estudos quando me senti desinteressado. & \\
\hline 7. Esforcei-me mais quando percebi que estava perdendo o interesse no assunto. & \\
\hline 8. Revisei a matéria para verificar o quanto eu dominava o conteúdo. & \\
\hline 9. Esforcei-me para verificar minha compreensão sobre o que estava sendo ensinado. & \\
\hline 10. Busquei solucionar minhas dúvidas ao consultar as apostilas do curso. & \\
\hline 11. Busquei compreender melhor os conteúdos ao estudá-los nas apostilas do curso. & \\
\hline 21. Fiz anotações sobre o conteúdo do curso. & \\
\hline 25. Refleti sobre as implicações que os conteúdos aprendidos poderiam ter. & \\
\hline 27. Associei os conteúdos do curso aos meus conhecimentos anteriores. & \\
\hline 29. Identifiquei situações diárias em que eu pudesse aplicar os conteúdos do curso & \\
\hline \multicolumn{2}{|l|}{ Controle da Emoção } \\
\hline 1. Mantive a calma quando tive dificuldades. & \\
\hline 3. Mantive a calma com a possibilidade de ter um rendimento abaixo do esperado. & \\
\hline 4. Mantive a calma diante dos erros que cometi ao realizar atividades do curso. & \\
\hline \multicolumn{2}{|l|}{ Estratégias Cognitivas } \\
\hline 12. Busquei auxílio do tutor para esclarecer minhas dúvidas sobre o conteúdo. & \\
\hline 13. Busquei auxílio de colegas nos fóruns para esclarecer minhas dúvidas. & \\
\hline 14. Troquei mensagens com os colegas para esclarecer dúvidas sobre o conteúdo do curso. & \\
\hline $\begin{array}{l}\text { 17. Tentei entender o conteúdo ao aplicá-lo na prática, ao invés de dedicar tempo lendo ou } \\
\text { pedindo ajuda a alguém. }\end{array}$ & \\
\hline 19. Aprendi conteúdos ao mentalizá-los repetidamente até perceber que havia entendido. & \\
\hline 20. Repeti mentalmente os conteúdos do curso que gostaria de aprender. & \\
\hline 23. Li o conteúdo do curso várias vezes como método para aprender. & \\
\hline 24. Fiz esquemas do conteúdo do curso como método para aprender. & \\
\hline Estratégias Comportamentais & \\
\hline $\begin{array}{l}\text { 15. Busquei outras fontes de pesquisa, fora da internet, relacionadas ao curso para me ajudar } \\
\text { a aprender. }\end{array}$ & \\
\hline 16. Busquei sites relacionados ao conteúdo do curso para me ajudar a aprender. & \\
\hline
\end{tabular}

